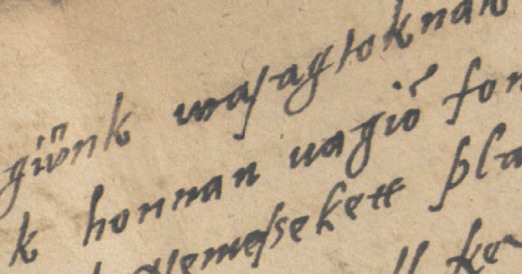

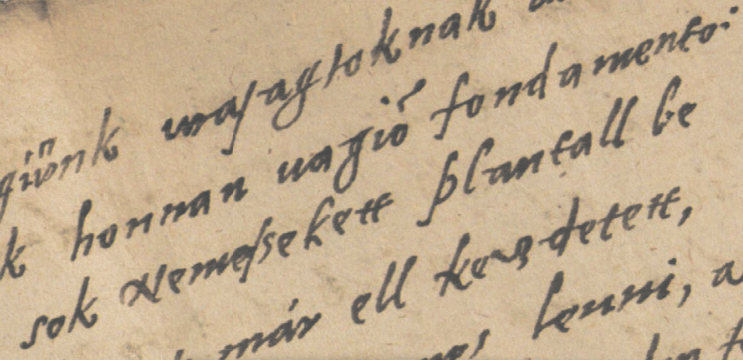

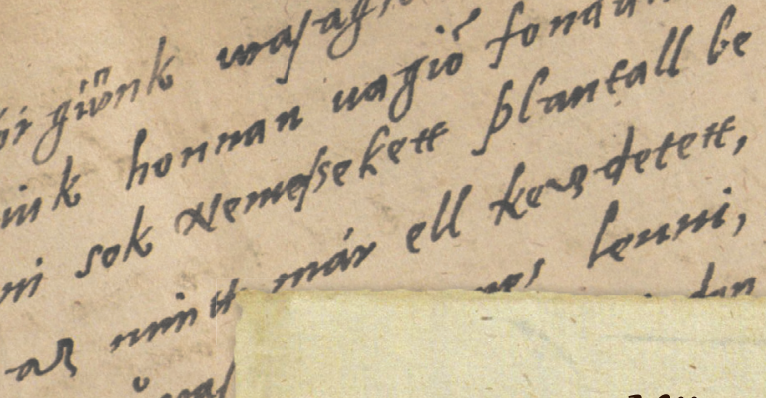
i inam!

„Könyörüljön tenagyságtok rajtunk!"

pasite, as

50 irat a XVI. századi jobbágylevelezésböl

in jet $^{\text {t }}$

Közreadja

lia $m^{e^{n s}}$

Dömötör Adrienne - Varga Mónika

(1) 2 raf?

(Eckhardt Sándor kiadásának felhasználásával)

kin ar om artis ma ment

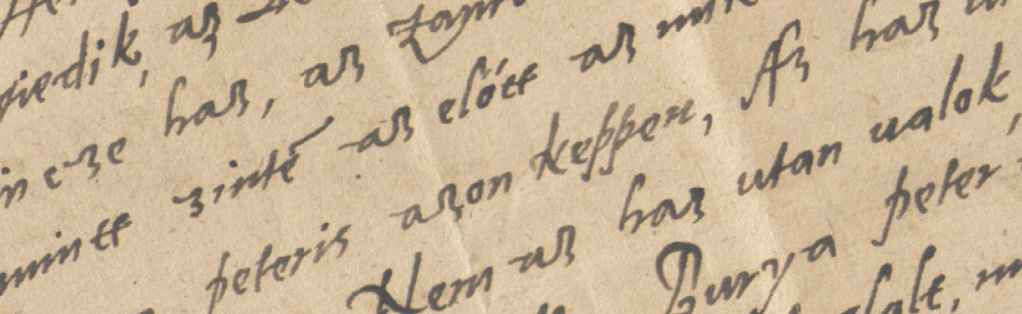

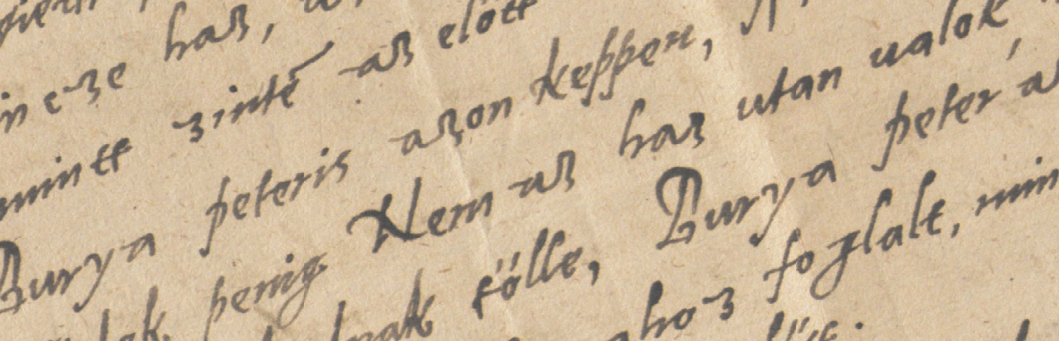

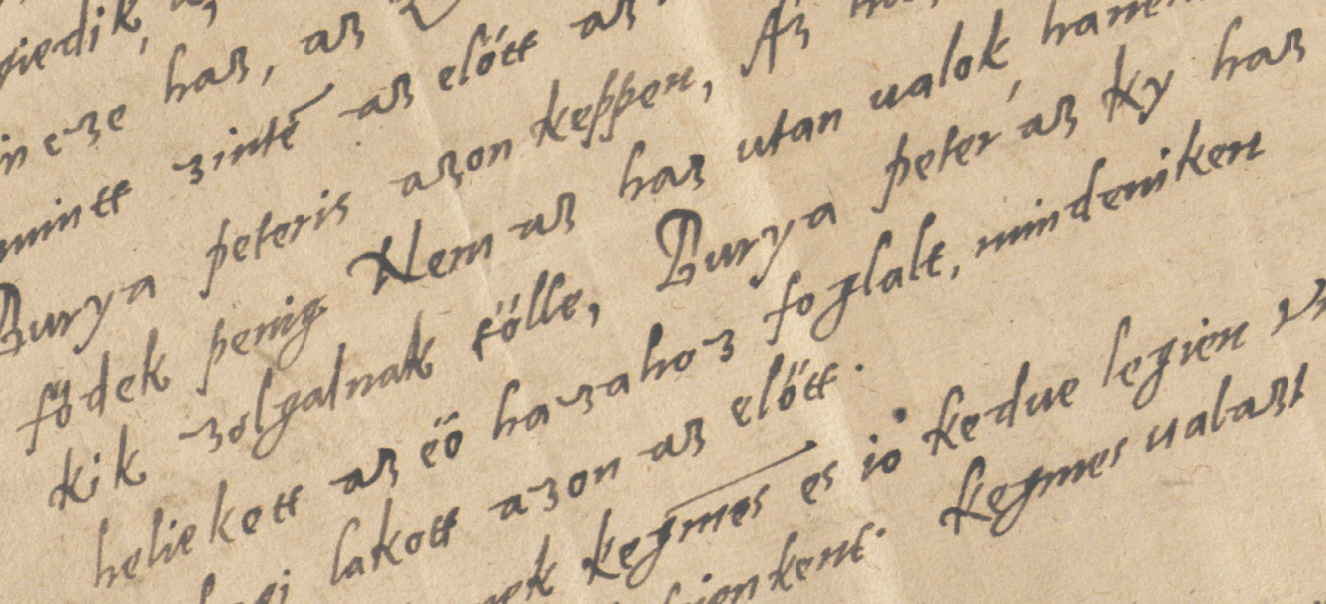


„Könyörüljön tenagyságtok rajtunk!”

50 irat a XVI. századi jobbágylevelezésből 



\title{
„Könyörüljön tenagyságtok rajtunk!” \\ 50 irat a XVI. századi jobbágylevelezésből
}

\author{
Közreadja \\ DöMÖTÖR ADRIENNE \\ VARGA MÓNIKA
}

(Eckhardt Sándor kiadásának felhasználásával)

Magyar Nyelvtudományi Társaság - Magyar Nemzeti Levéltár Budapest, 2018. 
A levelek másolata a Magyar Nemzeti Levéltárban készült.

\author{
Lektor: Haader Lea.
}

A latin részleteket az eredetivel egybevetette: Körmendy Kinga, N. Fodor János, Szentgyörgyi Rudolf.

A tulajdonnévmutatókat készítette: Korompay Eszter.

Technikai szerkesztő: Molnár Anna Aliz, Szabó Panna.

A kiadvány megjelenését az OTKA K 81189 sz. projektuma támogatta.

Minden jog fenntartva. Bármilyen sokszorosítás, illetve digitalizálás a kiadók előzetes hozzájárulásához van kötve.

(C) Közreadók, 2018.

ISBN: 978-615-5061-16-5

DOI: $10.26546 / 5061165$
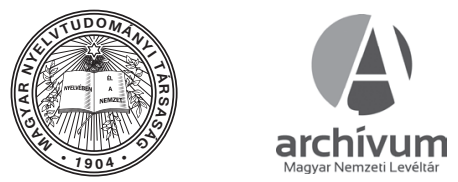

Nyomdai munkák: Komáromi Nyomda és Kiadó Kft.

Felelős vezető: Kovács János ügyvezető igazgató. 


\section{Tartalom}

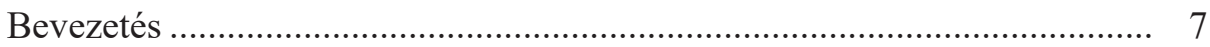

I. Levelek eredetiben és betühü átiratban ……....................................... 9

A szövegközlés módja ..................................................................... 11

31 levél jegyzetekkel ................................................................... 13

Az I.1-31. levél levéltári jelzete.......................................................... 190

II. Levelek utánközlésként ....................................................................... 193

Megjegyzés …............................................................................. 194

19 levél a korábbi átirat szerint ........................................................ 195

A II.1-19. levél első megjelenésének helye ...................................... 225

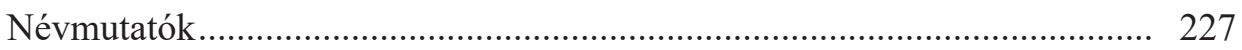

A levelekben előforduló tulajdonnevek ......................................... 229

A levelekben előforduló helynevek ................................................. 233 



\section{Bevezetés}

1. A Magyar Nyelv címü folyóirat „Nyelvtörténeti adatok” rovatában 1949 és 1963 között Eckhardt Sándor a XVI. századi jobbágylevelezésből ötven iratot (illetve iratrészletet) jelentetett meg.

A misszilisek különösen fontos forrást kínálnak a nyelvtörténeti kutatásokhoz, mivel az élőnyelvhez közeli regiszterbe engednek betekinteni - a változások pedig jellemzően a beszélt nyelvben kezdődnek. Ezért úgy gondoltuk, hasznos lenne, ha ez a fontos, de rejtekező levélanyag összegyüjtve, új kiadásban is rendelkezésre állna. Előzetes terveink szerint olyan kötet készült volna, amely csak annyiban lépett volna túl a puszta utánközlésen, amennyiben - a modern filológiai kívánalmaknak megfelelően - a levelek eredetijének fakszimiléjét is tartalmazza. (Ezúton szeretnénk köszönetet mondani Eckhardt Sándor jogörökösének, dr. Eckhardt Sándornak, hogy tervünkhöz hozzájárulását adta.)

A levelek eredetijét a Magyar Nemzeti Levéltárban a Magyar Nyelv számaiban megadott jelzetek alapján próbáltuk összegyüjteni. (Itt köszönjük meg Németh György és Németh István fölevéltárosoknak a források fellelésében nyújtott segítségét.) Hamar kiderült azonban, hogy az iratoknak csak egy részét lehet a folyóiratszámokban megjelent információk alapján előkeríteni. 31 levelet találtunk meg, míg 19-nek az eredete minden erőfeszítésünk ellenére ismeretlen maradt. Így le kellett arról tennünk, hogy kötetünk az ötven nyomtatott változattal párhuzamban ötven fakszimilét tartalmazzon.

De a nyomtatott szövegeket illetően is el kellett térnünk a kezdeti terveinktől. Miután ugyanis a fellelt 31 eredeti levelet összevetettük a nyomtatásban megjelent megfelelőikkel, azzal szembesültünk, hogy a betühünek szánt átiratok nagyon sok ponton - betütévesztések, téves olvasatok, kimaradó szavak vagy sorok, központozási hiányosságok - eltérnek az eredetijüktől. Továbbá az egyes levelek különböző közlési elveket követnek: van, hogy a latin részletek kimaradnak, máskor viszont szerepelnek; a rövidítések az egyik levélben fel vannak oldva, de jelölve vannak, a másik levélben jelöletlen marad a feloldás, a harmadikban megmarad a rövidítés. Néhány esetben pedig a teljes levélnek csak egy rövidebb-hosszabb részlete jelent meg.

Ezek után az tünt járható útnak, hogy a 31 szöveget az eredeti leveleknek megfelelően újra átírjuk, a korábbi közlés alkalmával kihagyott részeket is pótolva bennük. Lehetőségeink - számítógépeinken a levelek digitalizált, kinagyítható és helyben akárhányszor ellenőrizhető változatával - nyilvánvalóan lényegesen jobbak voltak, mint elődeinké. A levelek közlésében egységes elveket érvényesítettünk (ezekröl 1. lentebb). Mindennek megfelelően a kötet első részében a 31 levél fakszimiléje mellett a saját átiratunk szerepel.

A kötet második részében azonban - a fentebb leírtak értelmében - nem volt másra lehetőségünk, mint hogy a fennmaradó 19 levelet (illetve levélrészletet) pusztán újra közöljük. Bizonyos típusú vizsgálatok alapanyagának ezek is alkalmasak, azonban annak, aki kutatni szeretné őket, némi óvatossággal tanácsos 
eljárnia, hiszen jó okkal tételezhetjük fel, hogy ezek sem mentesek azoktól a szövegátírási problémáktól, amelyek a többiben is megmutatkoztak.

A kötetet záró személynév- és földrajzinév-mutatót a teljes levélanyag alapján készítettük el.

2. A gyüjtemény levelei zömmel a XVI. század második feléből valók. Az I. rész anyaga 1547 és 1590, a II. részé pedig 1574 és 1592 között keletkezett; a leveleket mindkét részben időrendben közöljük. Az iratok kevés kivétellel a Pozsonyban müködő Magyar Kamara, illetve a Szepesi Kamara levéltáraiból származnak, amelyek anyagát a Magyar Nemzeti Levéltár irattípusok szerint, azon belül pedig időrendben őrzi. A kamara - amellett, hogy pénzügyi kormányszerv volt - részt vállalt nemcsak a közigazgatásban és bizonyos politikai ügyek kezelésében, hanem a jogügyigazgató révén különböző állam- és magánjogi kérdésekkel kapcsolatos eljárásokban is. A Magyar Kamarát Budán állították fel 1528-ban, ahonan 1531ben költözött Pozsonyba. Kassán és Eperjesen először igazgatóságot müködtettek, majd Kassán - a felső-magyarországi régió pénzügyigazgatásának intézésére 1567-ben felállították a Szepesi Kamarát.

Az itt közölt levelek általában panaszokat, többnyire jobbágyok panaszait fogalmazzák meg. Olykor birtokosok vagy hivatalnokok számolnak be bizonyos ellentétekről, illetve a megvádolt földesurak kimagyarázkodása képezi a levél tárgyát.

Bár a XVI. század derekán a fórangúak már szinte kivétel nélkül tudtak írni, a parasztság körében ekkor még nem lehet azzal számolni, hogy értettek volna a betủvetéshez. A jobbágyok tehát csak írástudók segítségével tudták panaszaikat megfogalmazni, akik közül némelyek olykor nevesítik is magukat a levél végén. A magasabb rangú személyek írhatták leveleiket saját maguk, illetve írathatták íródeákkal is - van rá példa, hogy ez utóbbi a levél szövegéből ki is derül.

A levelek külalakja, a levélírók hibái és javításai arra vallanak, hogy az iratok végső formája túlnyomó többségében tisztázatként, másolással keletkezhetett; ugyanennek a jele, hogy két levél örszót is alkalmaz. De olyan levél is akad a gyüjteményben, amelyben az írás külalakja eredeti fogalmazványra enged következtetni.

A levelek külzetére jellemző, hogy a magyar vagy latin nyelvü címzésen kívül a hivatali beérkezéskor is kerül rá (latin nyelvü) feljegyzés. 


\section{I. \\ Levelek eredetiben és betühủ átiratban}

Közreadja: Dömötör Adrienne, Varga Mónika 



\section{A szövegközlés módja}

Az alábbiakban az a 31 levél következik, amelyeket - mivel eredetijük fellelhető volt - saját átiratunkban közlünk, a szövegek fakszimile másolatával együtt. A fotók méretarányosan kicsinyítve szerepelnek. A többoldalas levelek a fényképmásolatok mellett lapszámot kapnak, külön jellel arra az esetre, amikor meg kellett törnünk egy-egy oldalt. Az iratokon olykor a levéltári jelölések is látszanak.

Az átírás alapelve a betűhűség volt. A Régi Magyar Kódexek című sorozat kiadási útmutatójának megfelelően azonban átiratunk nem tükrözteti az $s$ betük különféle korabeli változatait, ahogyan a $z$-k formái között sem tesz különbséget. Az $s z$ írásmódjában is a mai betünek megfelelö jelkapcsolatot követjük (annál is inkább, mivel az ún. „scharfes” $\beta$ írásképe sok esetben nem különíthető el az $\int+3$ együttállástól). A ligatúrákat a többi esetben is feloldva közöljük.

A lábjegyzetek kizárólag az írásképre vonatkoznak. Szövegközi helyeken a következő jelöléseket alkalmaztuk: $\langle\ldots>=$ a levélíró törlése; $[\ldots]=$ megsemmisült vagy olvashatatlan részlet (ha megállapítható a betüszám, a pontok száma mindkét esetben ennek felel meg); dölt betüs szedés = a latin rövidítések feloldása.

Vegyes levélanyagról lévén szó, a munkát megnehezítette, hogy különféle, egymástól olykor nagyban eltérő kézírások megoldásait kellett követni (illetve nem egyszer: megfejteni). Átírásunkban minden esetben arra törekedtünk, hogy az adott kézre jellemző vonásokhoz igazodjunk, és a kétes esetekben is ezekhez forduljunk segítségért. Például ha a levélíró alig tett különbséget az $a$ és az $o$ vagy az ún. „farkas” 3 és a $h$ betük megformálása között, a valószínüsíthető megoldást az adott levél megfelelő betüihez viszonyítottuk, törekedve a kézírásban fellelhetö szabályszerüségek leképezésére. Általános jellemző ugyanakkor, hogy a korabeli íráskép alapján a nagy $I$ és nagy $J$ betüt nem lehet megkülönböztetni. Itt azt tekintettük mérvadónak, hogy az adott szóban melyik hang szerepel, s annak a jelét írtuk le. A Jézus latinos névalakjában azonban az I-t választottuk (Iesus). Ezzel szemben a száruk hossza alapján különböztetjük meg egymástól a kis $i$ és kis $j$ betüket (fokozatok esetén a közepes hosszhoz viszonyítva a betüszárat).

A mellékjeleket és további jelöléseket illetően a következőképpen jártunk el. Alapvetően az összes jelet a lehető legpontosabban próbáltuk visszaadni. Azt azonban minden levélírónál egyesével mérlegeltük, hogy adott esetben a pontnál gyakran hosszabbnak, illetve a szokásos méretủ vesszőnél rövidebbnek látszó ékezetet melyik irányban egységesítsük. Továbbá ha a kéz bizonyos betüket következetesen mellékjel(ek)kel látott el / mellékjel(ek) nélkül írt, de szövegében egészen kivételesen elvétette az írásmódot, megtartottuk a nyilvánvalóan szándékolt jelölést. Ha azonban ingadozó volt az eljárása - még ha megállapítható is a fővariáns -, minden esetben ragaszkodtunk az eredeti változathoz. Ezt az elvet még az $y \sim \ddot{y}$ esetében is követtük, tekintettel arra, hogy a betü írásmódjának éppen átmeneti korszakában vagyunk. Ahol azonban a két pontos vagy a két vesszős ékezetek véletlenszerủen vonássá csúsztak egybe, vagy a két pont egyike lemaradt, 
a szándékolt írásmódnál maradtunk. Természetesen - mégoly apró - egységesítés is csak ott jöhetett szóba, ahol az adott mellékjelnek nincs megkülönböztető szerepe, vagy a használata nem mutat rendszerességet.

A központozási jeleket (vessző, pont) egy-egy iraton belül sem egységesítettük. Az elválasztójeleket ugyanúgy megtartottuk, ahogyan a levélíró kitette őket (sor vége vagy sor eleje vagy mindkét hely), jelölésükként azonban az elválasztás mai jelét használjuk. A magyar szavak fölötti rövidítésjeleket megtartottuk (ahol a levélíró lefelejtette őket, nem pótoltuk); jelzésükre - függetlenül az eredeti jel ivétől, hosszától - minden esetben vízszintes vonalkát használtunk. Ezt a fölé a betű fölé tettük, amely az adott iratban - a sokszor egymástól eltérően jelzett rövidítésekben - közös. (A datálásokban viszont nem tükröztettük az évszám fölötti vonásokat.) A levelek végén gyakran megjelenő kalligrafikus ,etc.” lezárást megtartottuk (különbséget téve ezzel a puszta díszítés és a díszítésben felismerhetö nyelvi elem között).

A régi kéziratok átírásában állandó kérdésként felmerülő nagybetü / kisbetü, illetve egybeírás / különírás döntési helyzetekben a következő szempontok mérlegelésével próbáltunk eljárni. Belátva, hogy a nagybetüválasztás három szempontja közül - méret, forma, funkció - egyik sem ad megbízható fogódzót, alapvetően arra próbáltunk törekedni: ami nagynak látszik, az átiratunkban is nagybetüvel szerepeljen (miközben tudjuk, hogy a nagyobb méret sokszor például a szókezdő helyzetből fakad). Az adott levélíró írásszokását mérlegelve nem jelöltük nagynak azt a betüt, amelyet mindig nagyobb méretünek ír (leggyakrabban a „farkas” 3 ilyen). Amikor egy betüt gyakran nagyobbnak ír, de a levélen belül a kisebb változat is megtalálható (például az $n$ vagy az $m$ hajlamos erre), a látottakhoz próbáltuk tartani magunkat. Tudjuk, hogy ezek az eljárások vita tárgyát képezhetik - föként ha még azt is számításba vesszük, hogy a betünagyságok többnyire fokozatokat mutatnak -, mivel azonban az átirat mellett a fakszimile is megtalálható, úgy gondoljuk, kinek-kinek lehetősége van a belátása szerinti korrekcióra. Az egybeírás és a különírás kérdéses eseteiben is ugyanezt lehet tanácsolni, mivel a szavak között többnyire meglehetősen ingadozó méretű szóközök nem adtak biztos fogódzót ahhoz, hogy teljesen következetesen járhassunk el. Itt is az egyéni levélírói szokásokat, illetve az ezeken alapuló valószínüsíthető megoldásokat próbáltuk követni.

A levelek bekezdéseit egységesen behúzással jelöljük, függetlenül attól, hogyan szerepelt az eredetiben (jellemző a kijjebb kezdés, olykor a sorkihagyás is). A levélzárások formai megoldásait azonban - a legszükségesebb egyszerüsítéssel - tükröztetni próbáljuk. A levél külzetén álló sorokat a Kivül és Kívül más kézzel írva megjegyzésekkel vezetjük be (ill. olykor: más kezekkel írva, ami arra utal, hogy a különböző feliratokat más-más - de a levél írójától eltérő - kéz rögzítette). 
31 levél jegyzetekkel 


\section{I.1.}

Jászó, 1547. VIII. 6. Szölössy János levele

Wÿtezlew wraÿm zolgalatum aÿanlassanak wtanna az te kegelmetek lewelit en erthem wernerius wram amÿben segitchegel lehet ewremesth lezen makaÿ Jannosses ewremesth zolgal ez elmult napokban mek Irtam walla te kegelmetek -nek mÿben al az dolok ersek wram mÿnd mek Jarthata az wrakat bathori wramnak depwtalta twl az tÿzan az ket nÿgwen penzt azt hÿzem hogÿ egeb oka nem hanem hogÿ az hwz hwz penzt ewkezÿben agÿak enekes ezet weztÿ mÿnth az elebÿnek twdom hogÿ ha ersek wramot Reÿa fokÿa te kegelmetek kez mek tagadnÿ leweletes adnÿ mÿnd wraknak mÿnd warmegeknek de ha ew eben belle kapwth erthÿk egÿ masth bathori wramal eztendeÿk wth $<$ J.a $>$ Jarÿak twl az tÿzan chak wgÿan lezen mÿnt az ellebÿ rawas Lassa te $\cdot k \cdot$ mÿth kel nekem mÿvelnem lam mek Irtam hogÿ agek nem mÿgek mÿk te $\cdot$ kegelmetek wÿtanossagot nem ad az en levelemre ha chak eben kel el menem ez tannossagal kez wagÿok hoza mek Ideÿt nem multha merth masth roÿak 


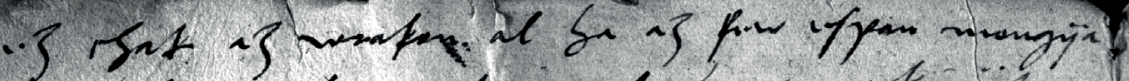
Sogj 6. agjit mift ijjit gumen wfingit

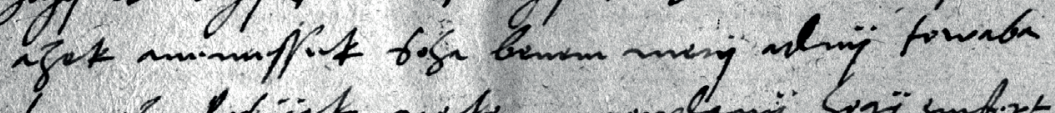

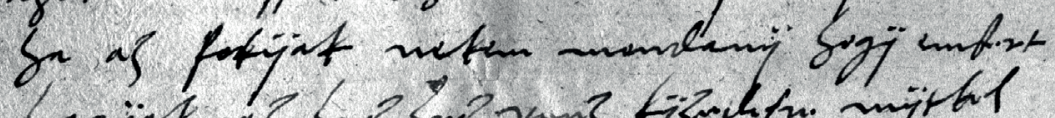

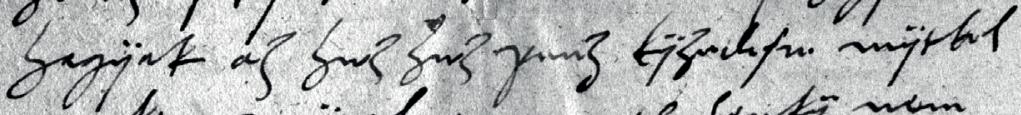
niftern ninjunlinem mentf suitf nem

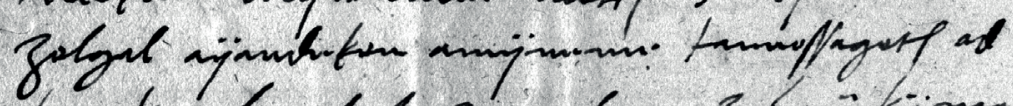

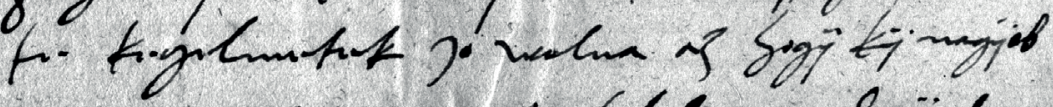

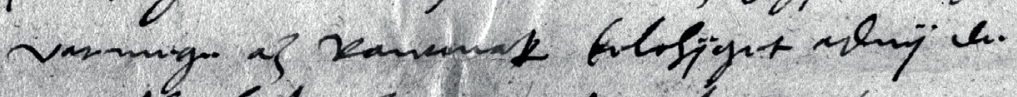

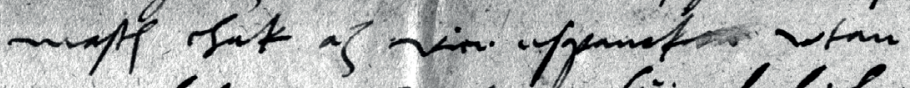

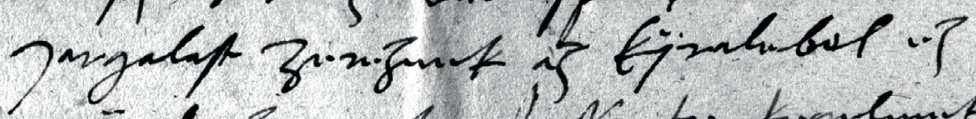

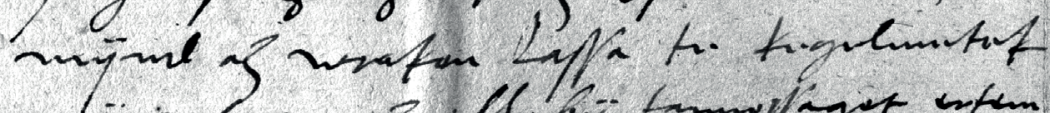

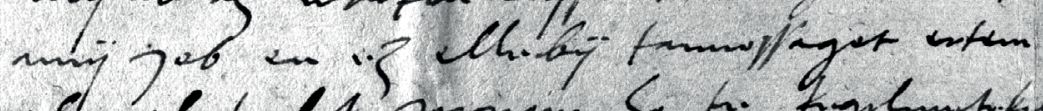

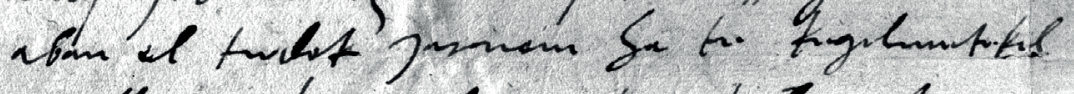

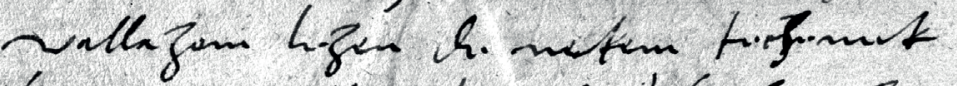

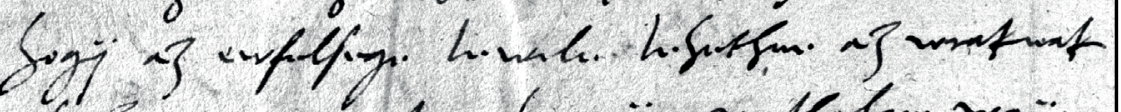

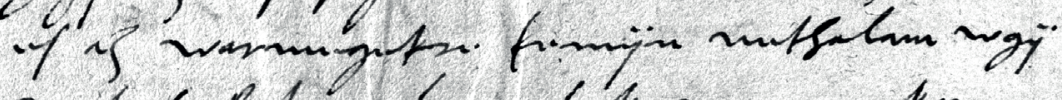
juter fiting $\mathrm{Si}$ infitt wram afome

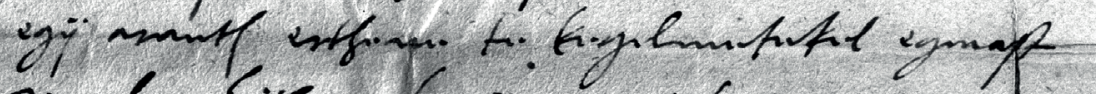

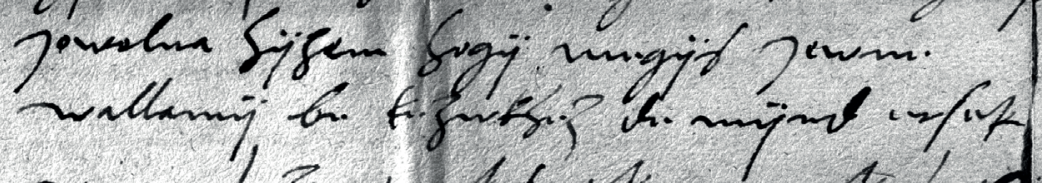

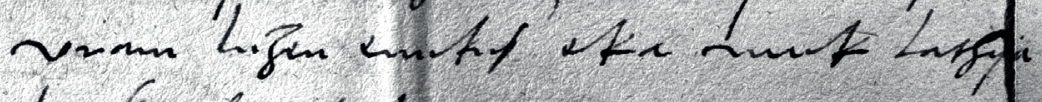

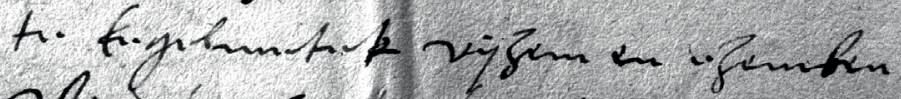

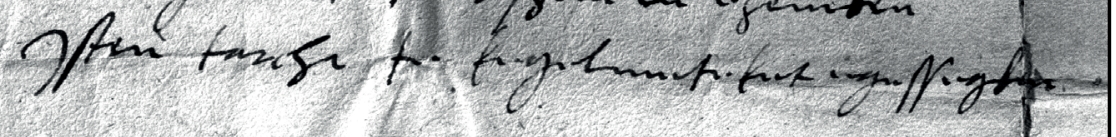


ez chak az wrakon al ha az few espan mongÿa hogÿ be agÿak mek agÿak hanem akarÿak azok anemessek soha benem merÿ adnÿ towaba ha az fokÿak ${ }^{1}$ nekem mondanÿ hogÿ embert hagÿak az hwz hwz penz kÿzedesre mÿtkel nekem mÿwelnem merth senkÿ nem zolgal aÿandekon amÿneme tannossagoth ad te kegelmetek Jo wolna az hogÿ kÿ nagÿob varmege az Rawonak kelchÿget adnÿ de masth chak az vice espanok $<. .>^{2}$ wtan Jargalast zereznek az kÿralebol ez mÿnd az wrakon Lassa te kegelmetek mÿ Job en ez ellebÿ tannossagot ertem aban el twdok Jarnom ha te kegelmetekel wallazom lezen de nekem techenek ${ }^{3}$ hogÿ az ewfelsege lewele lehethne az wraknak es az warmegekre kemÿn nethalam wgÿ Inkab fokna ha ersek wram akarna egÿ aranth erthene te kegelmetekel egmast Jowolna hÿzem hogÿ megÿs Jewne wallamÿ be kezwkhez de mÿnd ersek vram lezen enekes oka mek Lathÿa te kegelmetek vÿzem en ezemben Isten tarcha te kegelmeteket egessegben

\footnotetext{
${ }^{1}$ Az első $k$ javított betü.

${ }^{2}$ Két betünyi törlés, esetleg $r a$ lehetett.

${ }^{3}$ A $h z$-ből javított betü.
} 

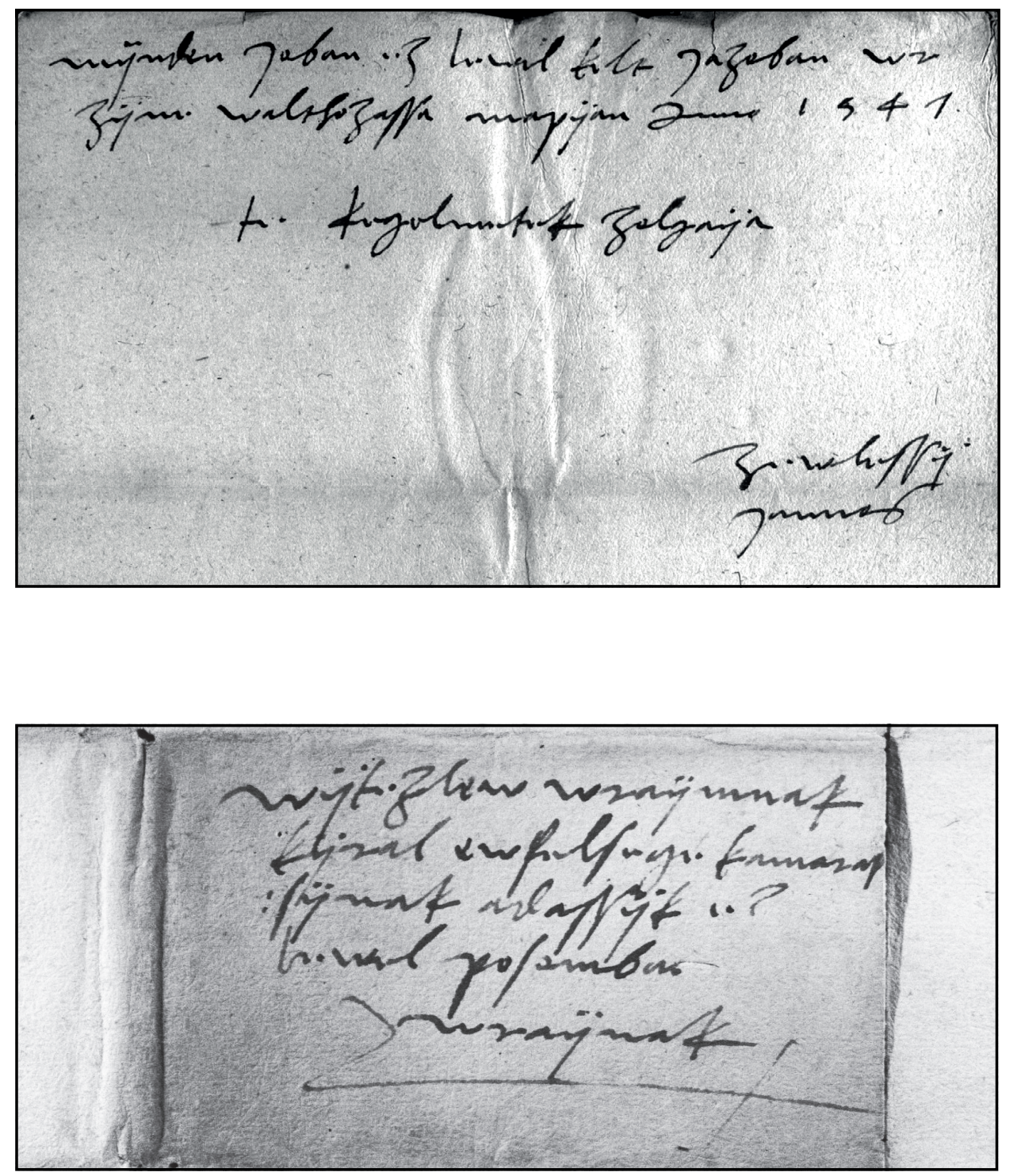
mÿnden Joban ez lewel kelt Jazoban wr zÿne walthozassa mapÿan Anno 1547

te kegelmetek zolgaÿa

Zewlessÿ

Jannos

Kìvül:

Wÿtezlew wraÿmnak

kÿral ewfelsege kamaras

-sÿnak adassÿk ez

lewel posomban ${ }^{4}$

wraÿnak

etc

${ }^{4} \mathrm{Az} a$ és az $n$ egyik szára közös. 


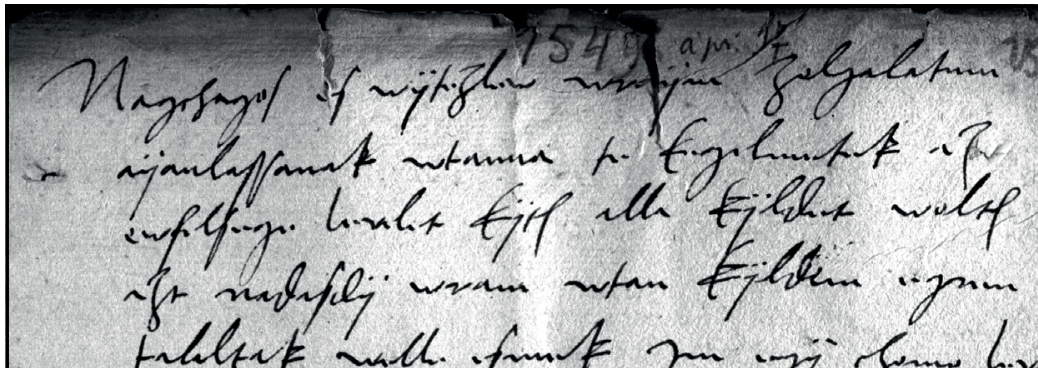

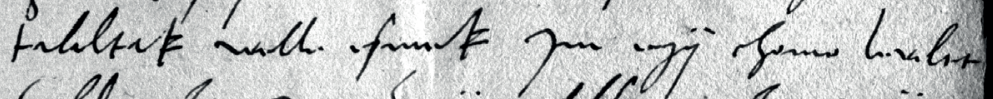

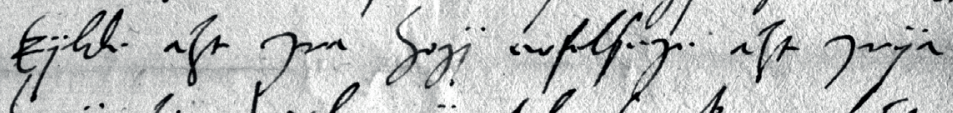

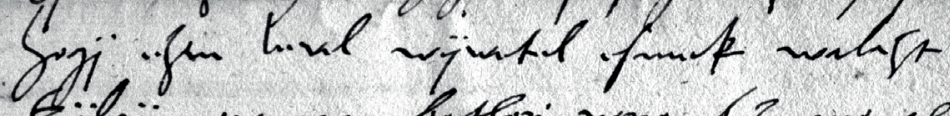

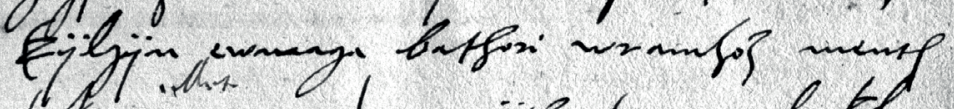

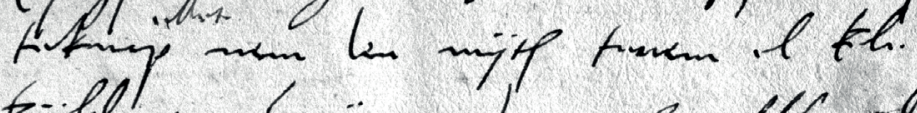

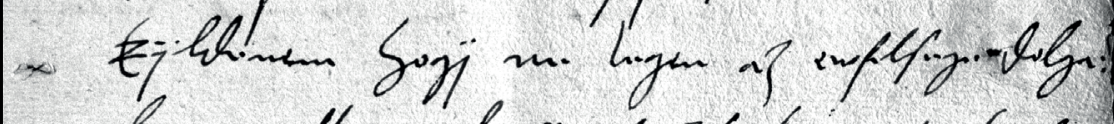

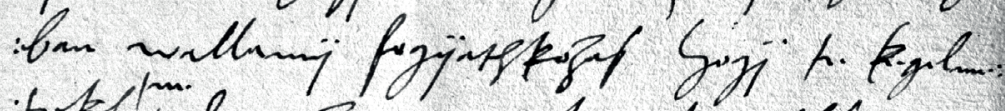

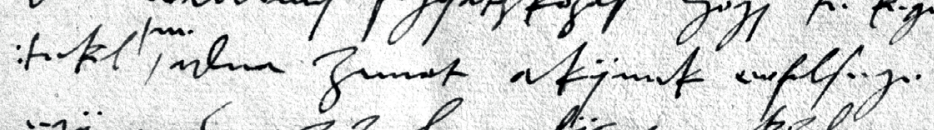

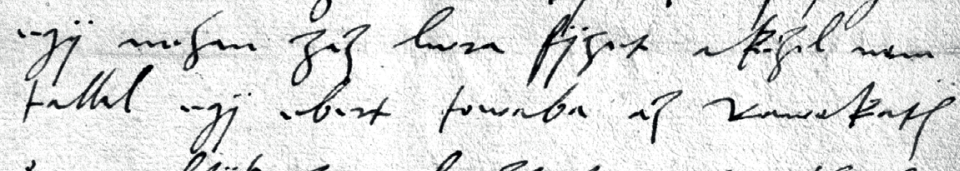

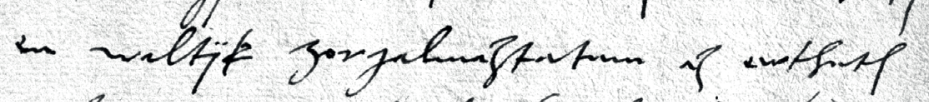

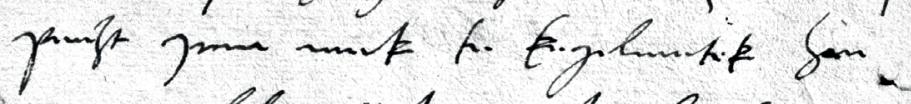
wumgre yjit at befsy in $k$

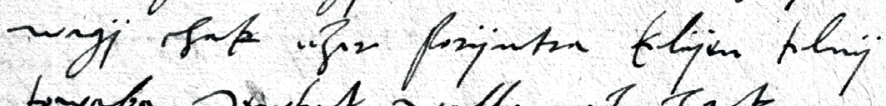

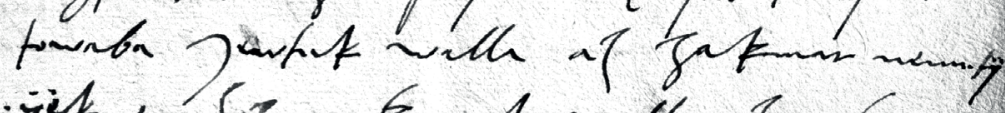

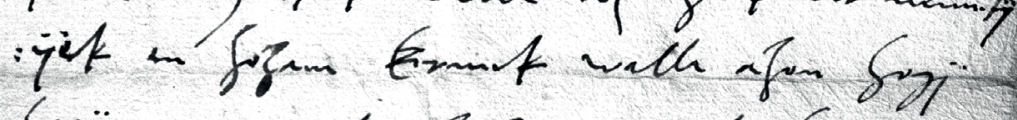

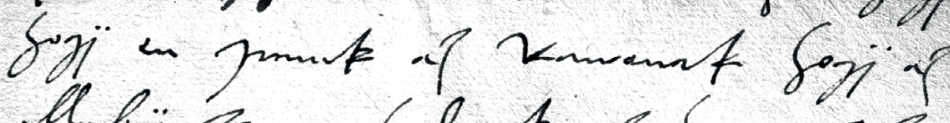

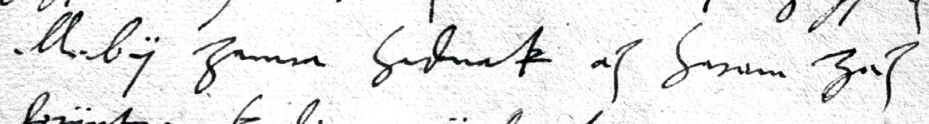

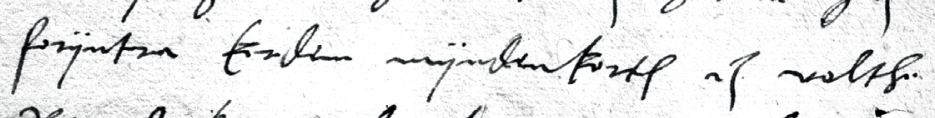

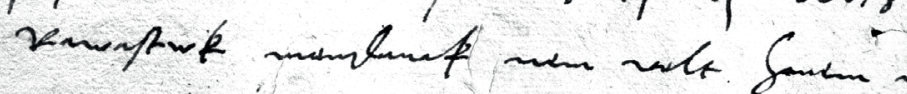




\section{I.2.}

Jászó, 1549. IV. 17. Szőlőssy János levele.

Nagchagos es wÿtezlew wraÿm zolgalatum

aÿanlassanak wtanna te kegelmetek az ewfelsege levelet kÿth alla kÿldet wolth azt nadasdÿ wram wtan kÿldem egren talaltak welle esmek Im egÿ chomo levelet kÿlde azt Ira hogÿ ewfelsege azt Irÿa hogÿ ezen level wÿwetel esmek walazt kÿlgÿn ewmaga bathori wramhoz menth teknap ellet ${ }^{1}$ nem len mÿth tenem el kele kÿldenem hogÿ ne legen az ewfelsege dolga-ban wallamÿ fogÿathkozas hogÿ te kegelme-tekel ne ${ }^{2}$ adna zamot akÿnek ewfelsege egÿ nehan zaz lwra fÿzet akezel nem tallal egÿ ebert towaba az rawakath en waltÿk zorgalmaztatum az ewtheth penzt Irna mek te kegelmetek han warmegebel agÿak mek bathorÿ wramnak wagÿ chak ezer forÿntra kelÿen telnÿ towaba Jwtek ${ }^{3}$ walla az zakmar nemetÿ -ÿek en hozam kernek walla azon hogÿ hogÿ en Irnek az rawonak hogÿ az ellebÿ zamra hadnak az harom zaz forÿntra kerdem mÿndenkorth az volthe rawastwk mondanak nem volt hanem mek

\footnotetext{
${ }^{1}$ A szó interlineáris betoldás a megfelelő helyre.

${ }^{2}$ A szó interlineáris betoldás, jelekkel a helyére utalva.

${ }^{3} \mathrm{Az} w$ javított betünek látszik.
} 


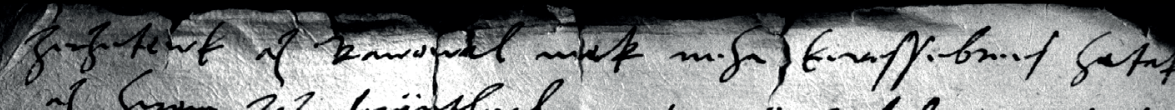

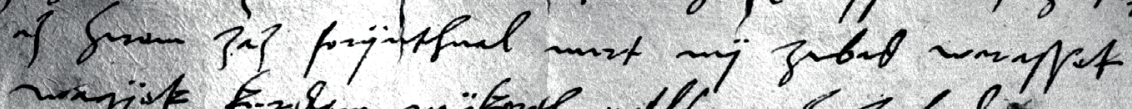

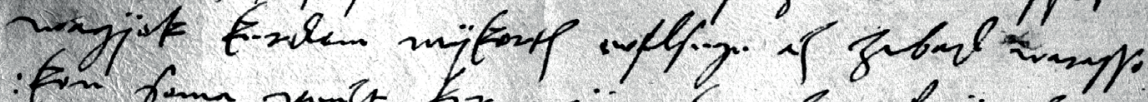

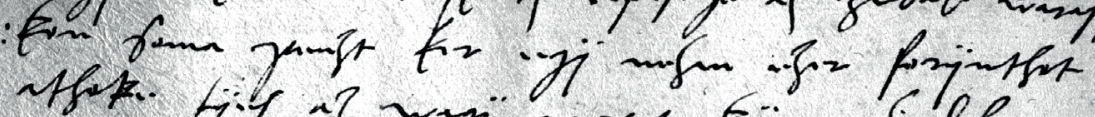

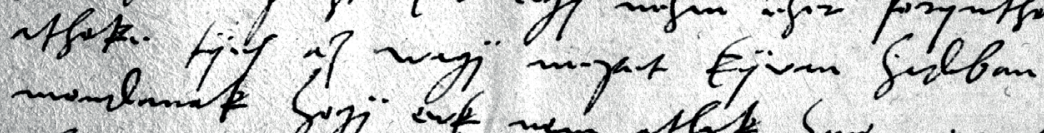

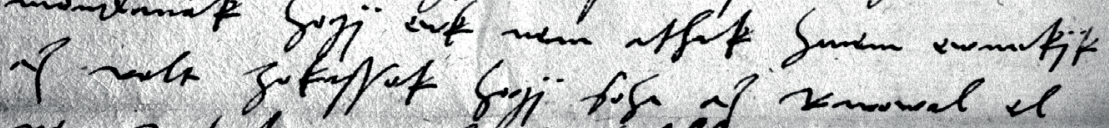

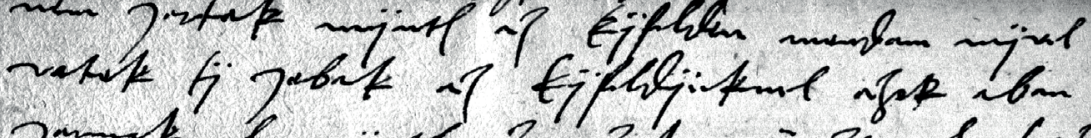

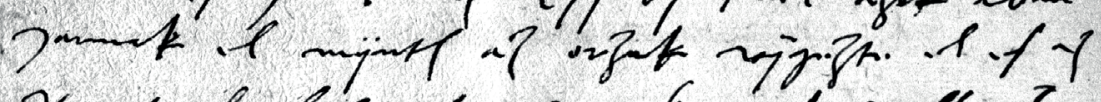

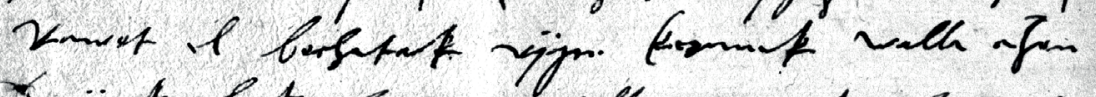

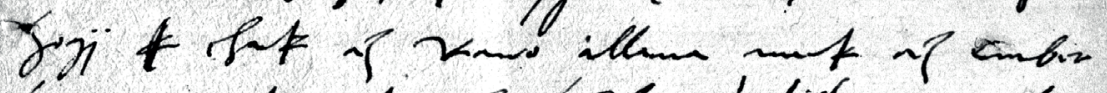
Sitio mat at of Siglom latik want

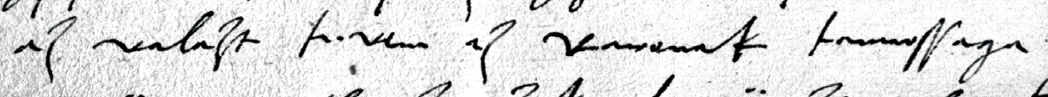

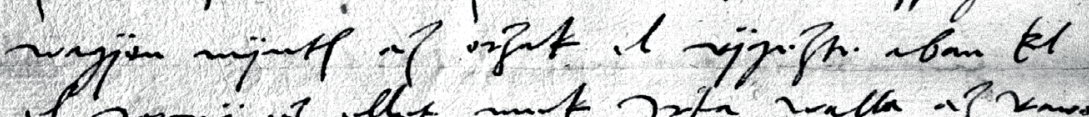

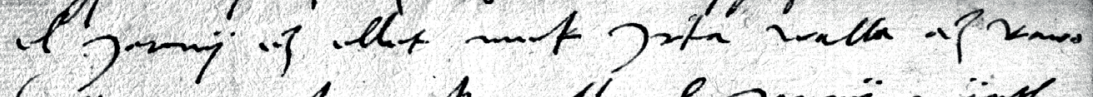

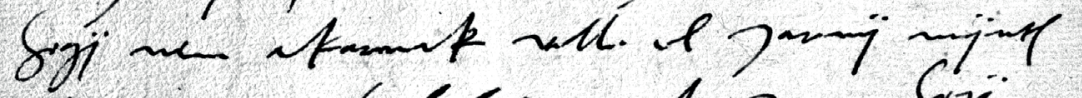
if nimong. Ëberfa mat 7 mam $\delta$

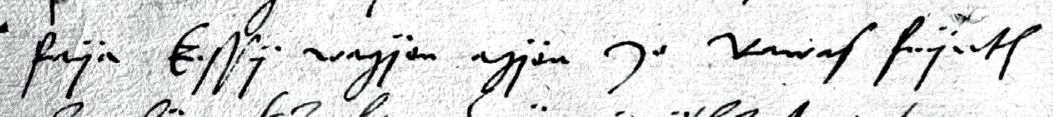

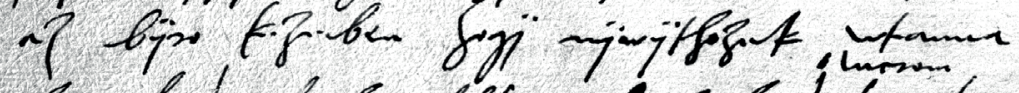

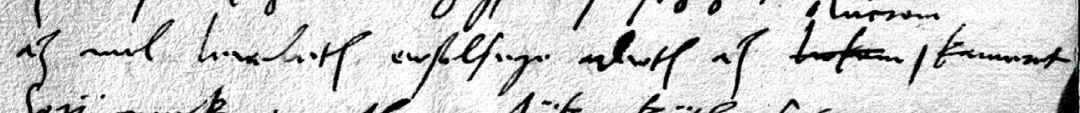

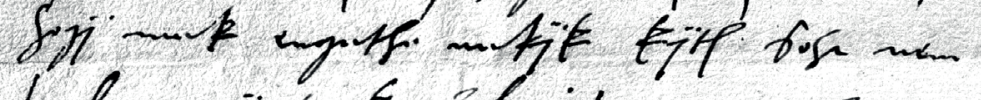

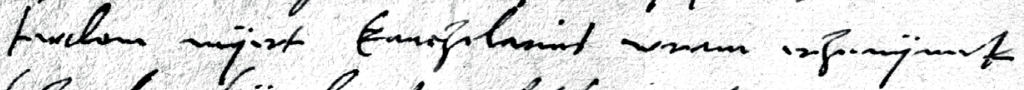

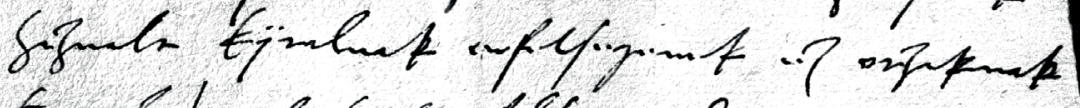

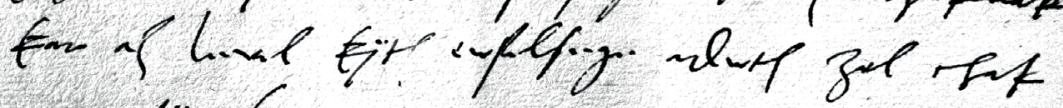

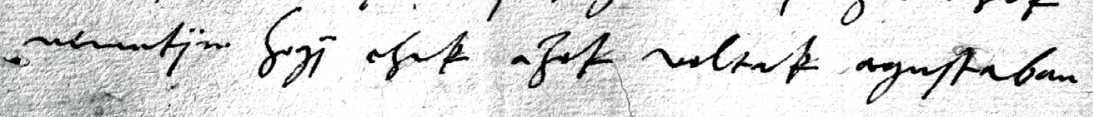


zerzetewk az rawowal mek neha kevessebrees hatak

az harom zaz forÿnthnal mert mÿ zabad warassok

wagÿok kerdem mÿkorth ewfelsege $e^{4}$ az zabad warasso

-kon soma penzt ker egÿ nehan ezer forÿnthot

athoke tÿes az wagÿ nepet kÿvan hadban

mondanak hogÿ ewk nem athak hanem ewnekÿk

az volt zokassok hogÿ soha az rawowal el

nem Jartak mÿnth az kÿfelden mondam mÿvel

vatok tÿ Jobak az kÿfeldÿeknel azok aban

Jarnak el mÿnth az orzak vÿgezte el es az

rawot el bochatak vÿgre kernek $^{5}$ walla azon

hogj $<\mathrm{k}>$ chak az rawo allana mek az ember

hÿtÿn mek akÿ az hazban lakÿk en arol

az valazt tevem az rawonak tanwssaga

wagÿon mÿnth az orzak el vÿgezte aban kel

el Jarnÿ ez ellet mek Irta walla az rawo

hogÿ nem akarnak velle el Jarnÿ mÿnth

az varmege kÿbochata mek Iram hogÿ

faÿa kessÿ wagÿon agÿon Jo rawas feÿeth

az bÿro kezeben hogÿ nÿwÿthozek wtanna

az mel leweleth ewfelsege adwth az $<$ lukom $>$ lucrom $^{6}$ kameret

hogÿ mek engethe nekÿk kÿth soha nem

twdom mÿert kanczelarius wram erzenÿnek

haznalt kÿralnak ewfelsegenek ez orzaknak

kar az level kÿth ewfelsege adwth zol chak

nemetÿre hogÿ chak azok voltak agustaban

\footnotetext{
${ }^{4}$ A második $e$ vonala bizonytalan.

${ }^{5}$ A második $r$ javított betü.

${ }^{6}$ A szó a törölt szó fölötti interlineáris betoldás, jelekkel a helyére utalva.
} 


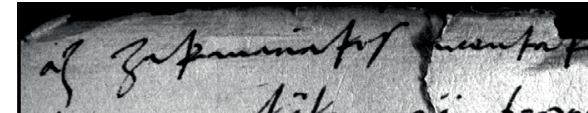

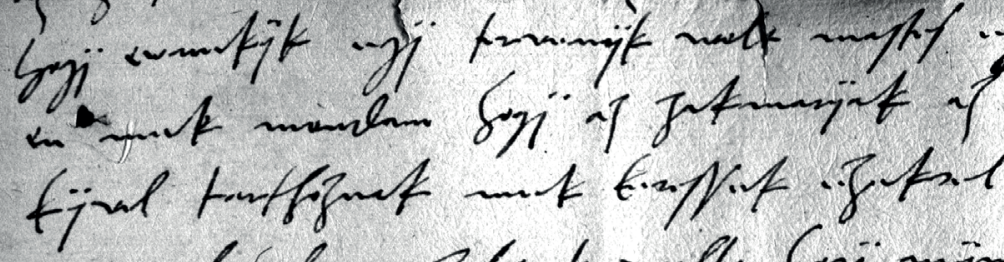

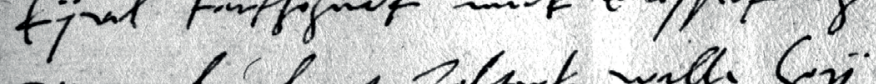

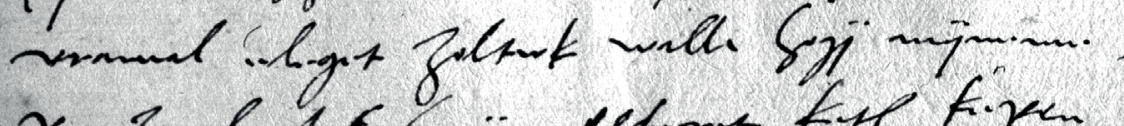

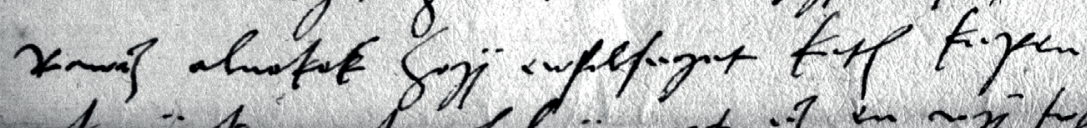

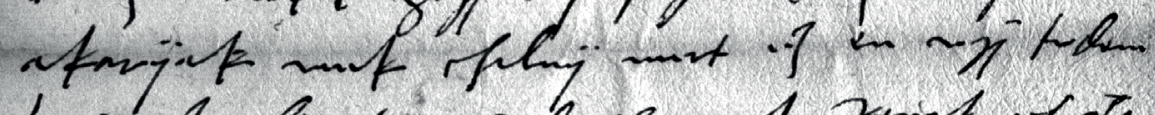

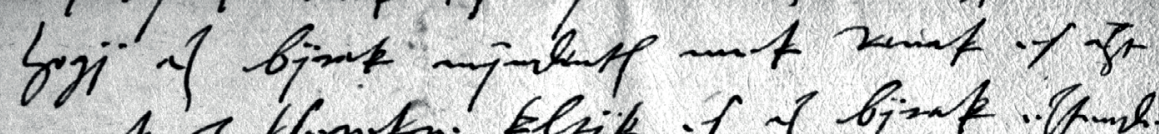

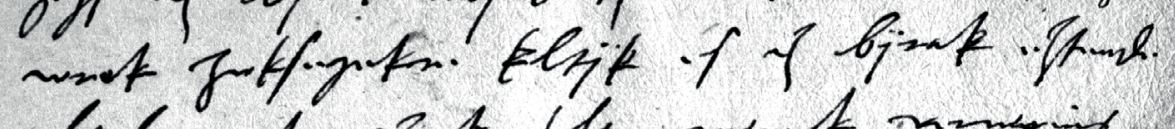
altal mot ifot flem ment nomsis

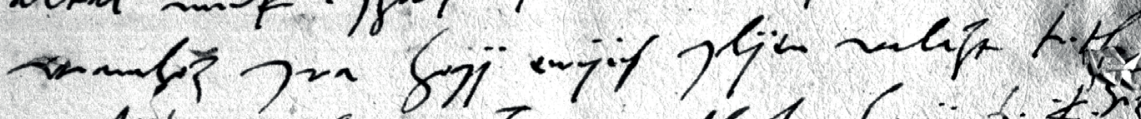

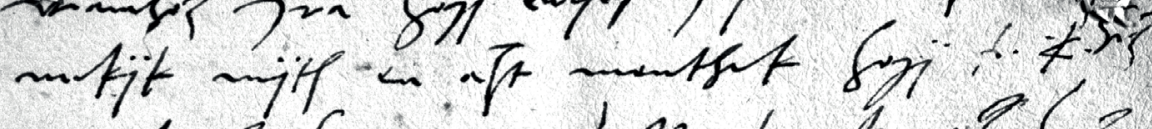

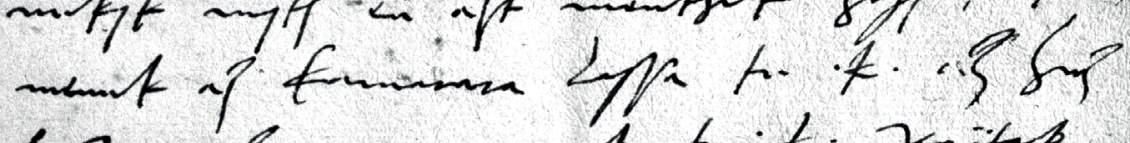

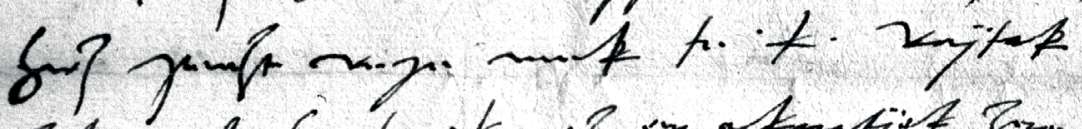

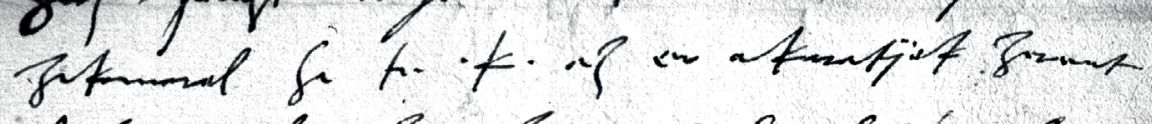

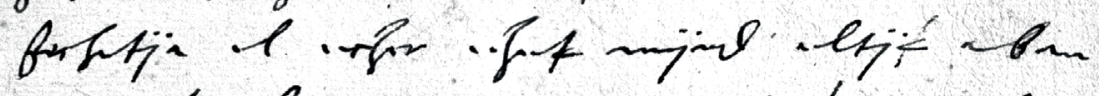
-mint il ift if vanumt lifin wht

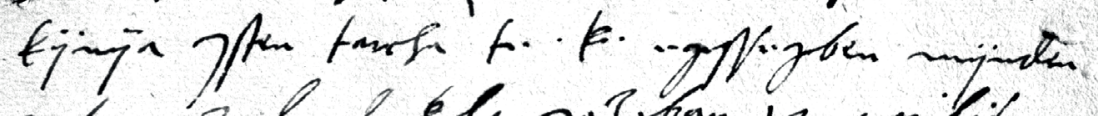

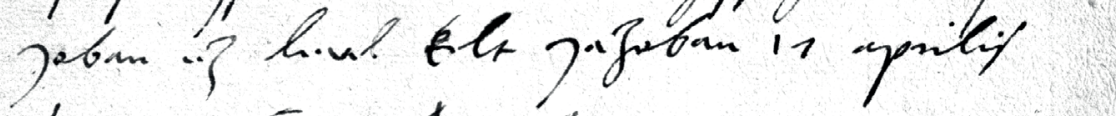
5442
t. Eghlontif zolgin

x

$$
\text { zonglif: }
$$


az zakmariakes wontak az level melle magokath hogÿ ewnekÿk egÿ tervenÿk wolt mastes ezen ${ }^{7}$ wagÿon en mek mondam hogÿ az zakmarÿak az kamarara kÿvel tarthoznak mek keressek ezekrel vernnerius vramal eleget zoltwk walla hogÿ mÿneme rawaz alnokok hogÿ ewfelseget keth kepen akarÿak mek chalnÿ mert ez en vgÿ tvdom hogÿ az bÿrak mÿndenth mek ronak es azt wrok zwksegekre keltÿk es az bÿrak eztende altal mek Izak telen menek vernerius ${ }^{8}$ vramhoz Ira hogÿ ewÿes Ilÿen valazt teth nekÿk mÿth en azt monthak hogÿ te $\cdot \mathrm{k} \cdot \mathrm{hez}$ menek az kamarara lassa te $\cdot \mathrm{k} \cdot \mathrm{az}$ hwz hwz penzt vege mek te $\cdot \mathrm{k} \cdot$ raÿtok zakmaral ha te $\cdot \mathrm{k} \cdot$ az ew akaratÿok zerent bochatÿa el eczer ezek mÿnd eltÿk aban ${ }^{9}$ menek el chak az rawonak lezen velek kÿnÿa Isten tarcha te $\cdot \mathrm{k} \cdot$ egessegben mÿnden Joban ez level kelt Jazoban 17 aprilis 1549

te kegelmetek zolgaÿa

\section{Zewlessÿ Janos}

${ }^{7}$ A feltehetően $r$-ből javított betű formája nem egyértelmű.

${ }^{8} \mathrm{Az} r$ javított betünek látszik.

${ }^{9} \mathrm{~A} b$ igazított betünek látszik. 


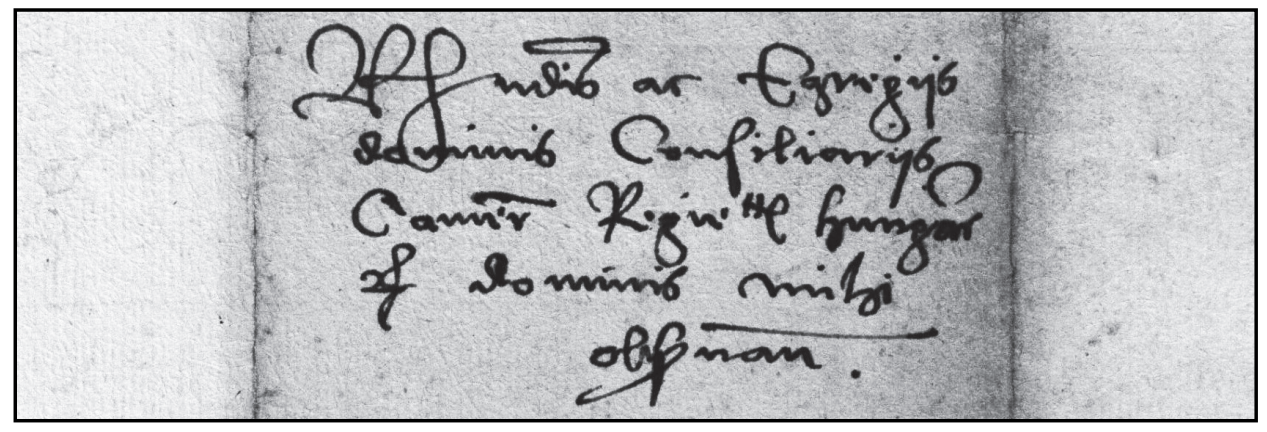


Kívül más kézzel írva:

Reverendis ac Egregÿs

dominis Consiliarÿs

Camerae Regietatis Hungarorum

et dominis mihi

obseruando. 


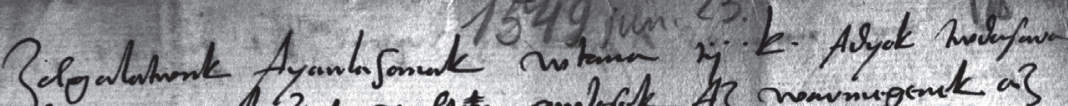

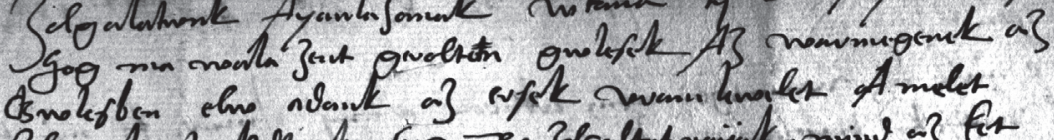

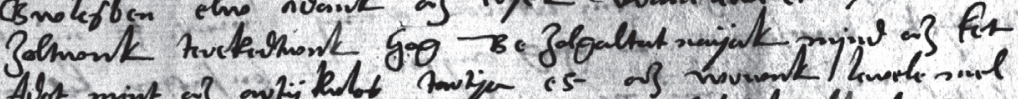

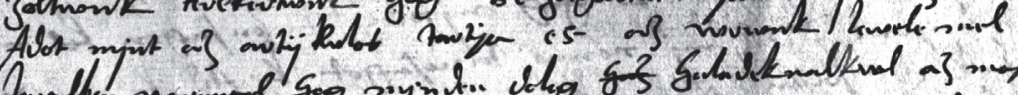

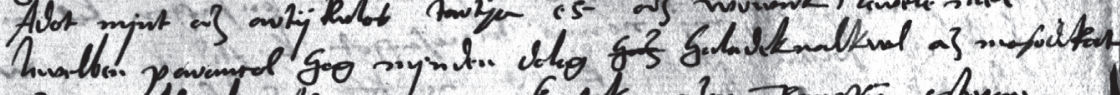

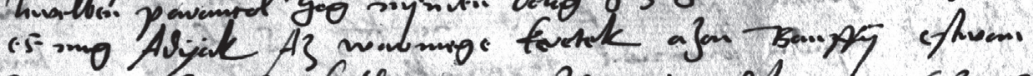

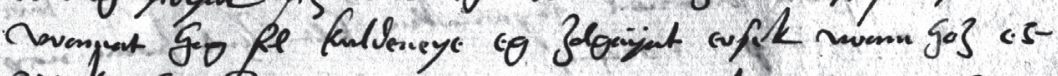

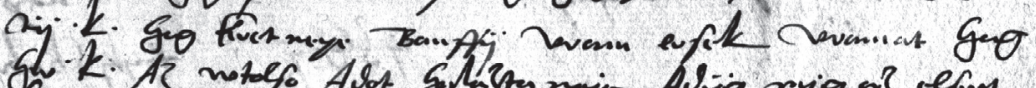

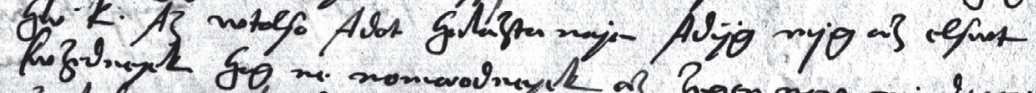

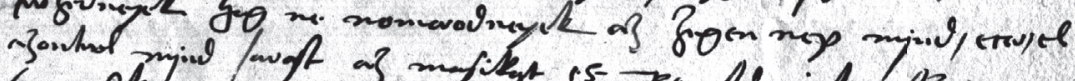

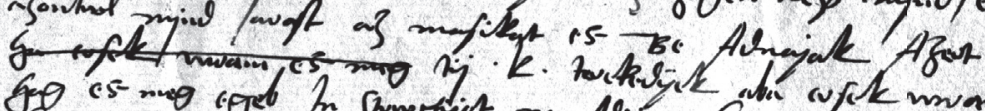

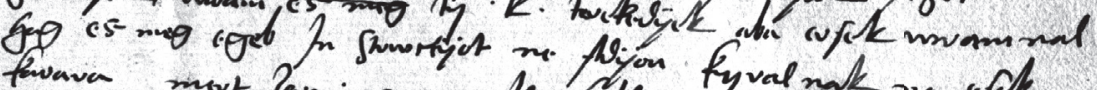

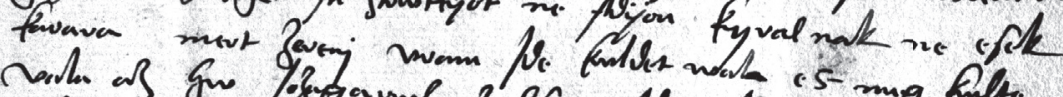

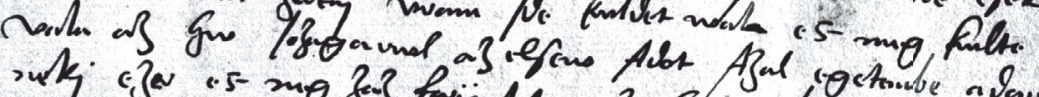

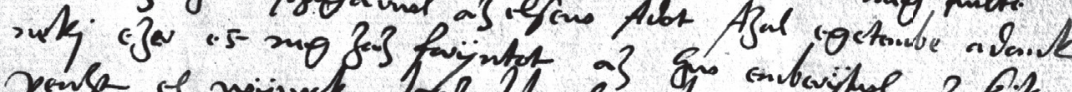

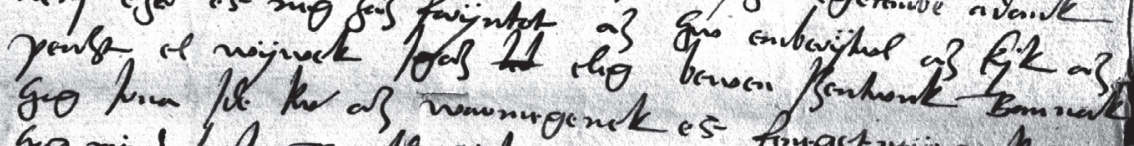

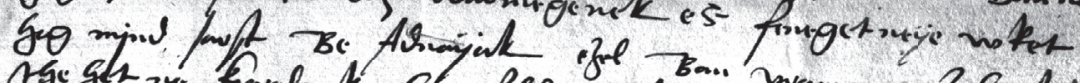

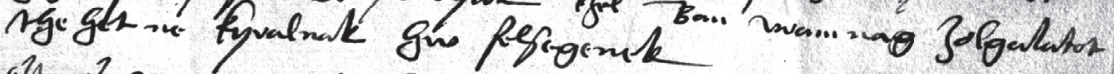

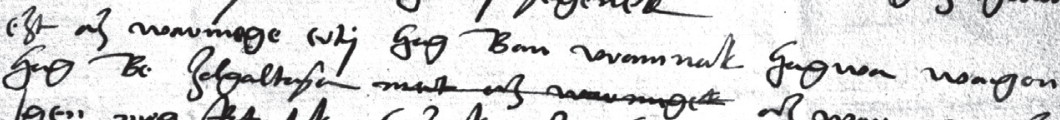

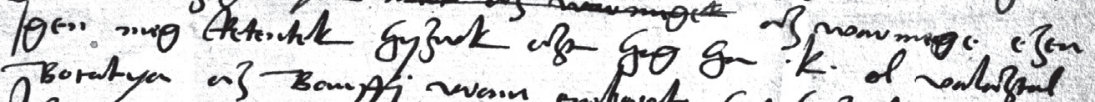

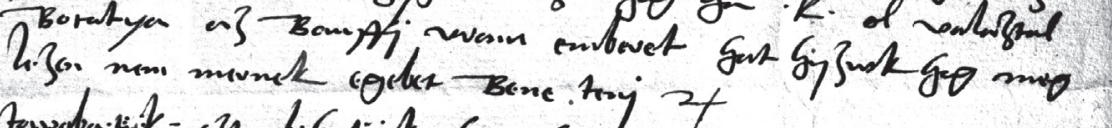

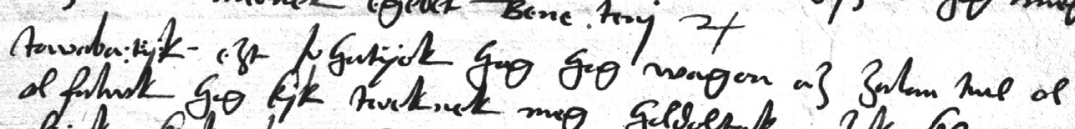

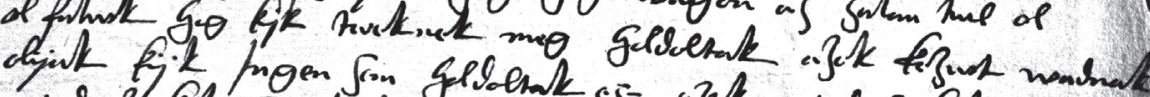

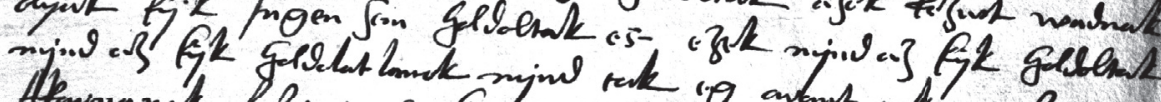

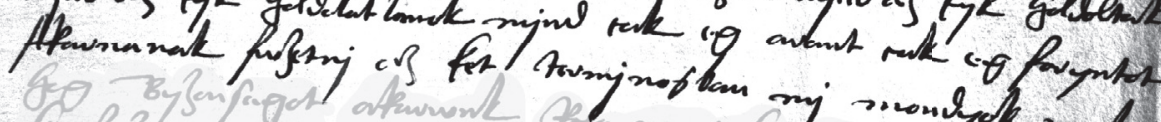

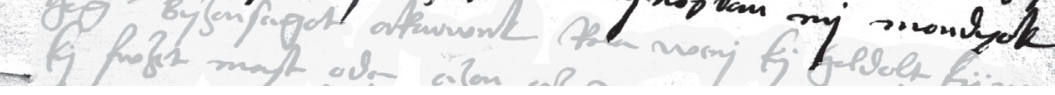




\section{I.3.}

Kapornak, 1549. VI. 23. Rajki Gábriel és Rajki János levele.

Zolgalatwnk Ayanlasanak wtana tÿ $\cdot \mathrm{k} \cdot$ Adyok twdasara hog ma wala zent gerolton ${ }^{1}$ gwlesek Az warmegenek az Gwlesben elw adank az ersek vram lewelet Amelet ${ }^{2}$ zoltwnk terekedtwnk hog Be zolgaltatnaÿak mjnd az ket Adot mjnt az artÿkwlos ${ }^{3}$ tartja es az wrwnk lewele mel lewelben parancol hog mjnden dolog $<$ haz $>$ haladeknalkwl az masodikat ${ }^{4}$ es meg Adÿak Az warmege keretek azon Banffÿ estwan vramat hog fel kwldeneye eg zolgaÿat ersek vramhoz es tÿ $\cdot \mathrm{k} \cdot$ hog keretneye Banffÿ vram ersek vramat hog $\mathrm{hw} \cdot \mathrm{k} \cdot$ Az wtolso Adot halaztanaja Adÿg mjg az elswt kwzedneyek hog ne nomorodneyek az zegen nep mjnd ecer ${ }^{5}$ el azontwl mjnd Jarast az masikat es Be Adnajak Azert $<$ ha ersek wram es meg $>$ ty $\cdot k \cdot$ terekedÿek aba ersek wramnal hog es meg egeb In strwctÿot ne Adÿon kyralnak ne esek karara mert Zerenj vram Ide kwldet wala es meg kwlte vala az hw Jozagarwl az elsew Adot Azal egetembe adank nekj ezer es neg zaz forÿntot az hw emberÿtwl az kjk az penzt el wÿwek Igaz $<$ lel $>$ eleg bewen Izentwnk Bannak hog Irna Ide $\mathrm{kw}^{6}$ az warmegenek es fenegetneÿe wket hog mjnd Jarst Be Adnaÿak ezel Ban vram nag zolgalatot thehetne kyralnak hw felsegenek

ezt az warmege ertj hog Ban vramnak hagwa wagon hog Be Zolgaltasa $<$ mert az warmege. $>$ az warmege ${ }^{7}$ ezen Igen meg Retentek hyzwk azt hog ha $\cdot \mathrm{k} \cdot$ ol valaztal Bocatya az Banffÿ vram emberet hat hyzwk hog meg lezen nem mernek egebet Bene tenj etc

towaba tÿ ${ }^{8} \mathrm{k} \cdot$ ezt Irhatÿok hog hog wagon az Zalan twl ol ol falwk hog kjk tereknek meg holdoltak azok kezwt wadnak olÿak kÿk Jngen sem holdoltak es ezek mjnd az kÿk holdoltak mjnd az kÿk holdolatlanok mjnd cak eg arant cak eg foryntot Akarnanak fwzetnj az ket terminosban mj mondyok wala

${ }^{1}$ A második $o$ javított betü.

${ }^{2} \mathrm{Az} A$ betủ alatt $a$ látszik (és esetleg egy megkezdett hosszú szárú betủ).

${ }^{3} \mathrm{~A} k$ alsó szára a $w$ bal oldali szárával a levélben több helyen is egybeesik.

${ }^{4} \mathrm{Az} i$ interlineáris betoldás.

${ }^{5}$ A szó két vessző (virgula) közé került, melyeknek funkciója ismeretlen.

${ }^{6} \mathrm{~A} w$-t követően téves vonal vagy félbehagyott betü látszik.

${ }^{7}$ A $g$ talán javított betü.

${ }^{8}$ A szó utólagos betoldás, jellel elkülönítve az előző szótól. 


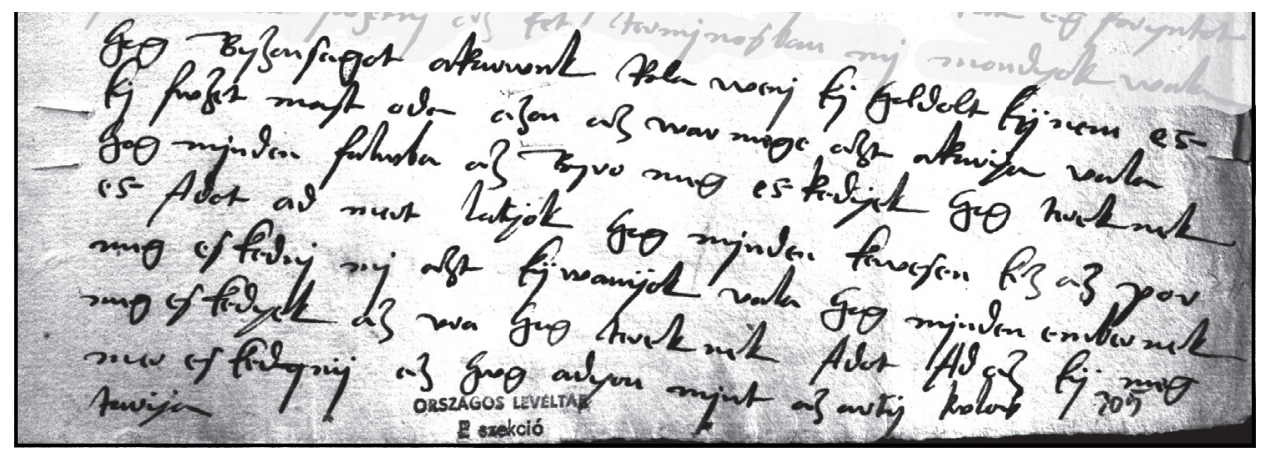

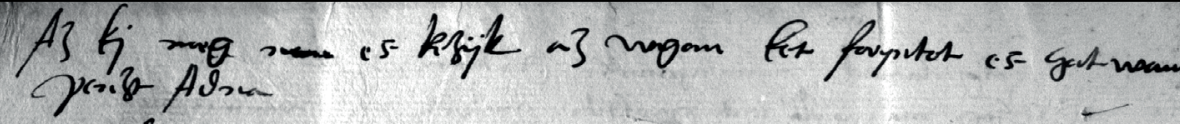

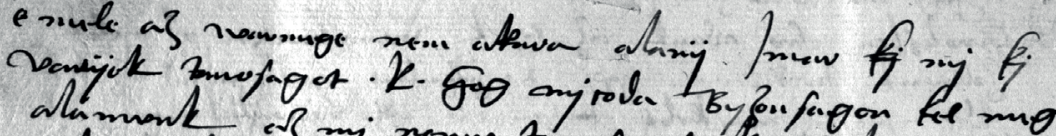

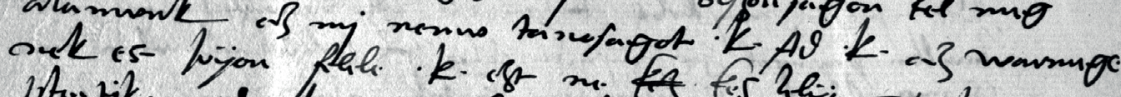

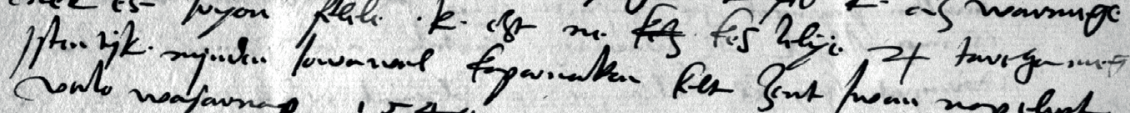
nafaunep i 54

$$
\begin{aligned}
& \text { ijoloni Aryk. (Babual es- } \\
& \text { Ahi's fanmos } 2
\end{aligned}
$$

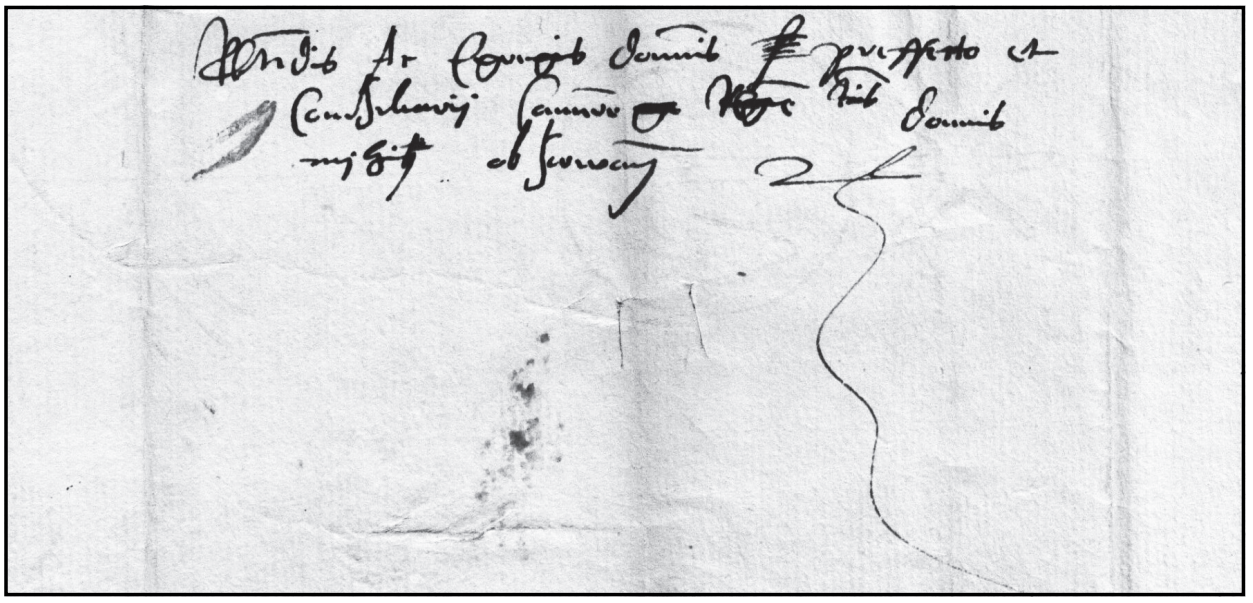


hog Byzonsagot akarwnk Rola wenj kj holdolt kÿ nem es kj fwzet mast oda azon az war mege azt akarÿa vala hog mjnden falwba az Byro meg eskedÿek hog tereknek es Adot ad mert latÿok hog mjnden kewesen kez az por meg eskednj mj azt kÿwanÿok vala hog mjnden embernek meg eskedyek az vra hog tereknek Adot Ad az kÿ meg mer eskednÿ az hwg adyon mjnt az artÿ kwlos tarÿa

Az kj meg nem eskezÿk az wgan ket foryntot es hatwam penzt Adna

e mele az warmege nem akara alanÿ Imar $<\mathrm{kj}>\mathrm{mj} \mathrm{kj}$ varÿok tanosagot $\cdot \mathrm{k} \cdot$ hog mjcoda Byzonfagon kel meg alanwnk az mj nemw tanosagot $\cdot \mathrm{k} \cdot \mathrm{Ad} \cdot \mathrm{k} \cdot \mathrm{az}$ warmege nek es Irÿon felele $\cdot \mathrm{k} \cdot$ ezt ne $<\mathrm{kez}>$ keslelÿe etc tarchameg Isten tjk · mjnden Jowawal kaparnakon kelt Zent Iwan nap elwt valo wasarnap 1549

$$
\begin{array}{r}
\text { tj zolgaÿ Raykj Gabryel es } \\
\text { Raÿky Jannos etc }
\end{array}
$$

Kívül, más kézzel írva:

Reverendÿs Ac Egregiis dominis $<\mathrm{f}>$ preffecto et $<$.> Consiliarÿ Camēre $<. .>$ Regietatis dominis mihi<.> obserwandys etc 


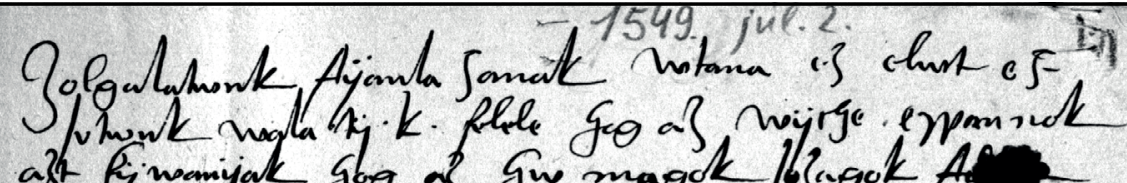

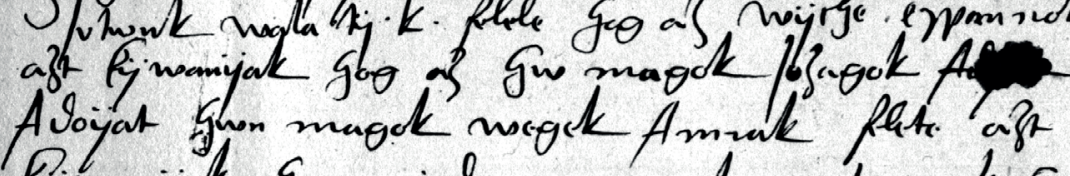

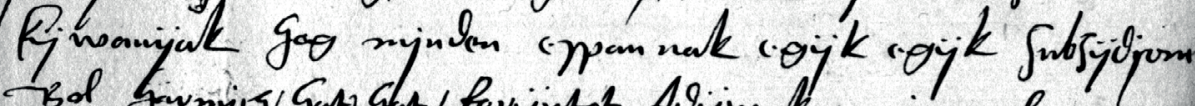
Bal Givinis/ Gant glat foryintot Alyiunk mi cme.

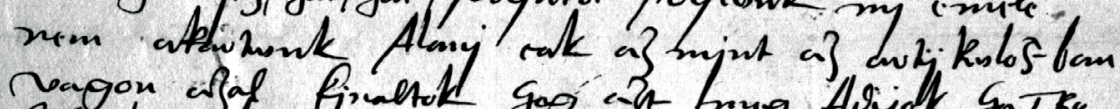

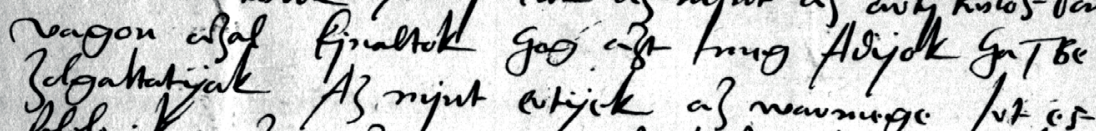

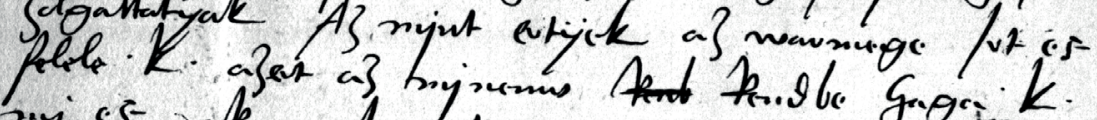

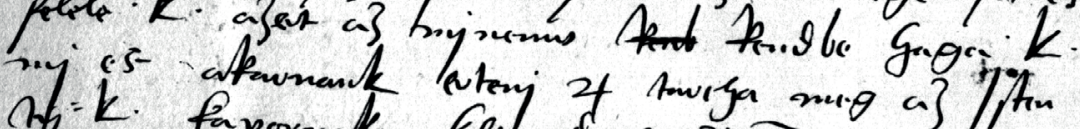

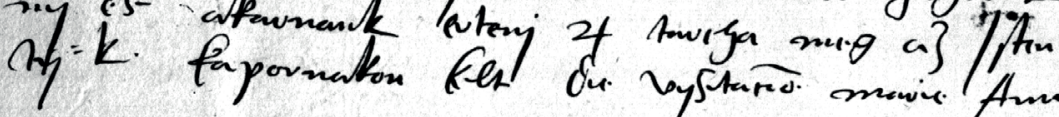

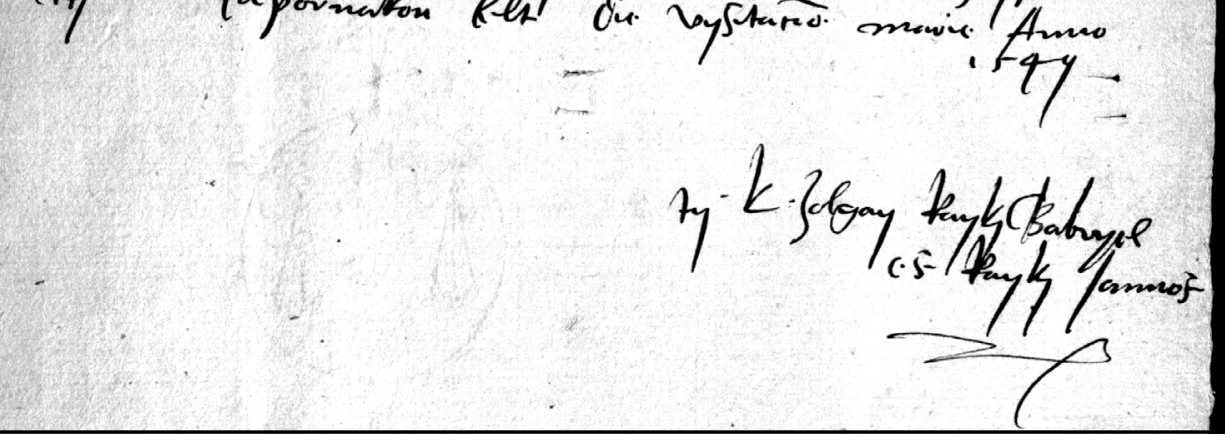




\section{I.4.}

Kapornak, 1549. VII. 2. Rajki Gábriel és Rajki János levele.

Zolgalatwnk Aÿanlasanak wtana ez elwt es ${ }^{1}$

Irtwnk wala tÿ $\cdot \mathrm{k} \cdot$ felele hog az wÿche espannok

azt kÿwanÿak hog az hw magok Jozagok Adoÿat ${ }^{2}$

Adoÿat hwn magok wegek Annak felete azt

kÿwanÿak hog mjnden espannak egÿk egÿk subsÿdjom

bol harmÿch / hat / hat / forÿntot Adÿwnk mj emele

nem akartwnk Alanj cak az mjnt az artÿkwlosban

vagon azal kjnaltok hog azt meg Adÿok ha / Be

zolgaltatÿak Az mjnt ertÿek az warmege Irt es

felele $\cdot \mathrm{k} \cdot$ azert az mjnemw $<$ Renb $>$ Rendbe haga $\cdot \mathrm{k} \cdot$

mj es akarnank ertenj etc tarcha meg az Isten

tÿ $\cdot \mathrm{k} \cdot$ kapornakon kelt die vysitationis marie Anno

1549.

$$
\begin{gathered}
\text { ty } \cdot \mathrm{k} \cdot \text { zolgay Raykj Gabryel } \\
\text { es Raykj Jannos } \\
\text { etc }
\end{gathered}
$$

${ }^{1}$ A szóvégi s-ek utáni vonás - itt és későbbiekben is - a betűformához tartozik.

${ }^{2}$ A tintafolt miatt olvashatatlanná vált a szó, ezért a levélíró megismételte. 


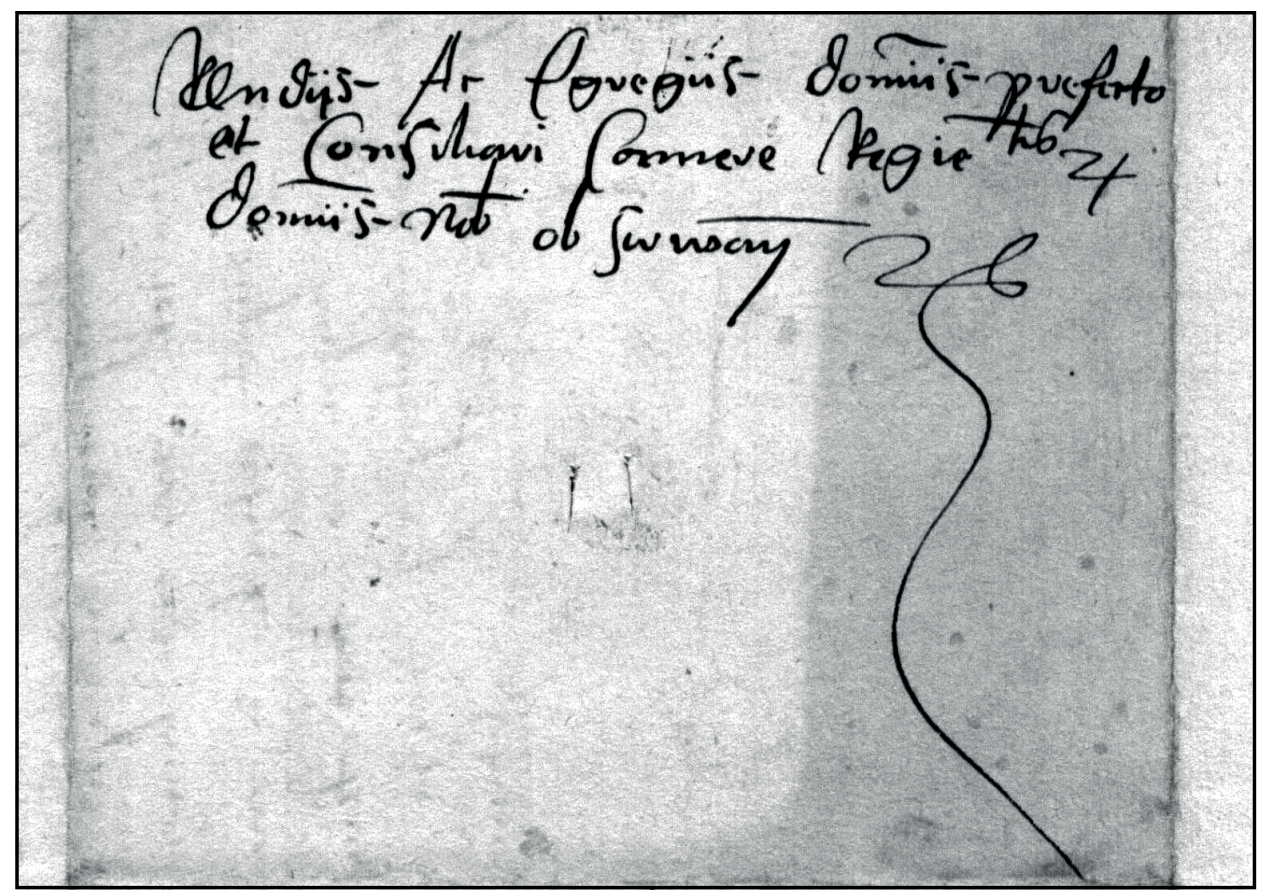


Kìül más kézzel írva:

Reverendÿs Ac Egregiis dominis prefecto

et Consiliari Camere Regietatis etc ${ }^{3}$

dominis nobis obserwandys etc

${ }^{3}$ A kéz itt az et helyén a - levélben több helyen is előforduló - etc. rövidítésjelét használja. 


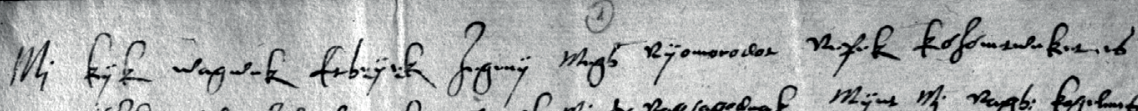

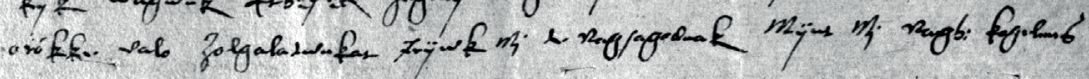

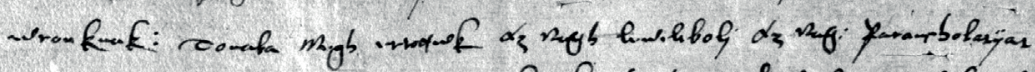

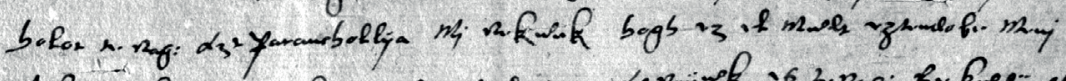

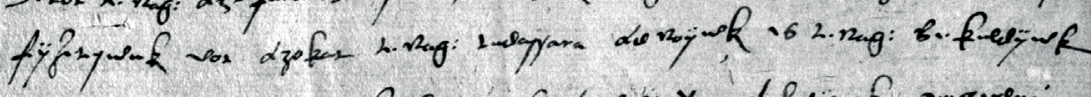

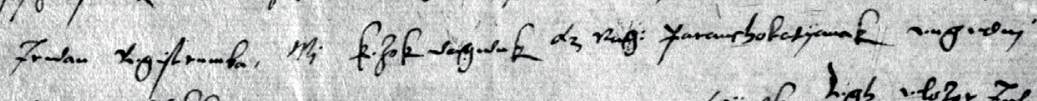

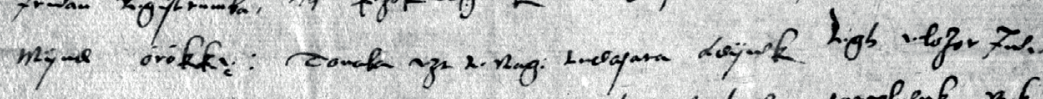

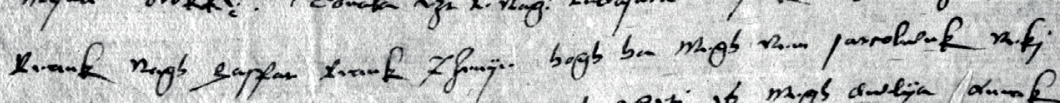

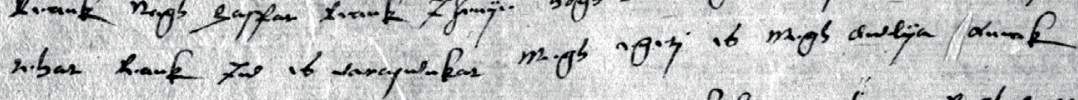

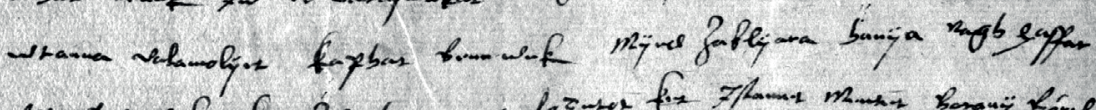

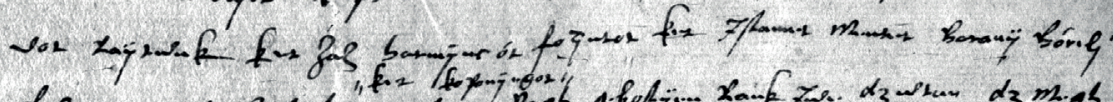

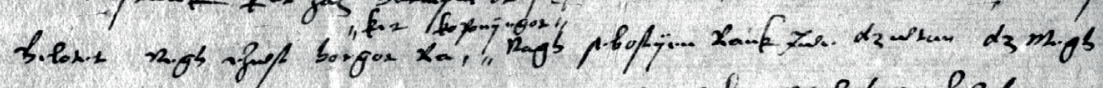

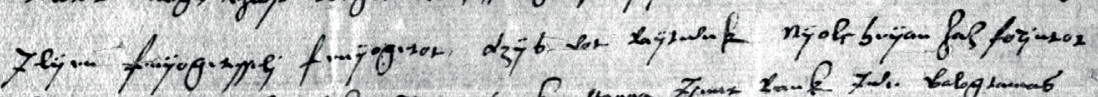

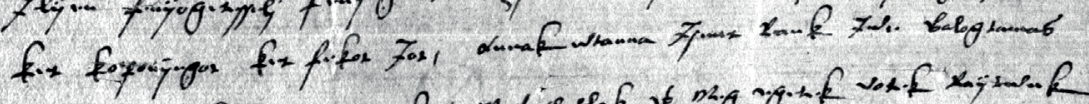

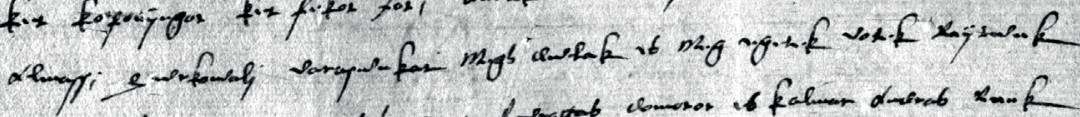

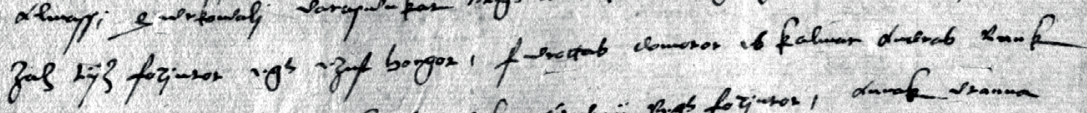

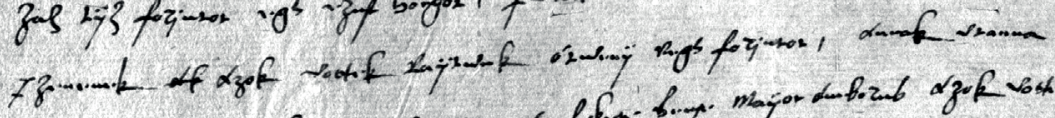

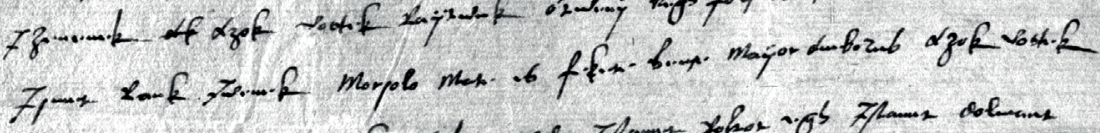

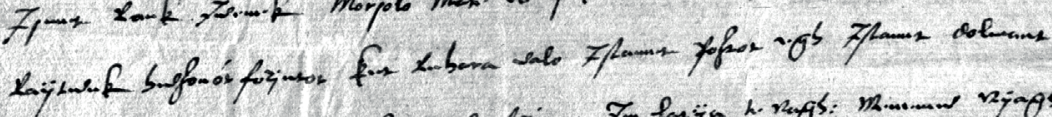

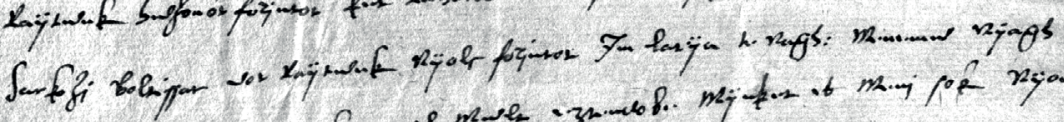

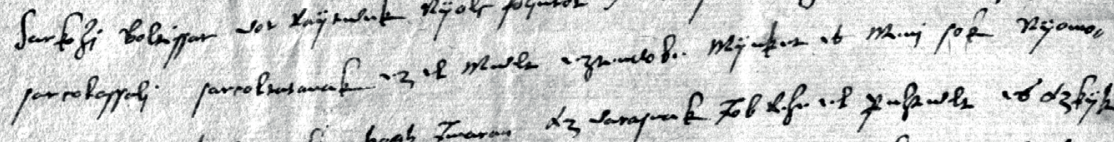

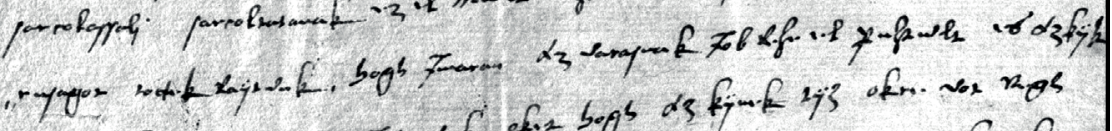

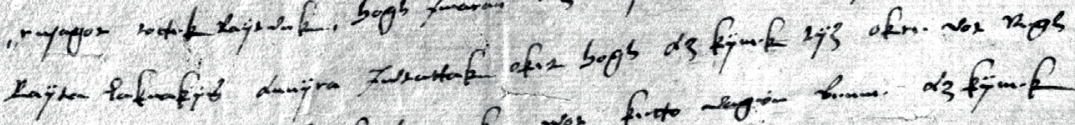

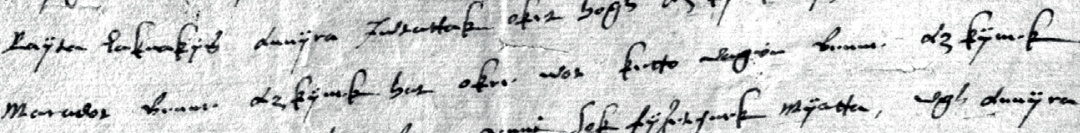

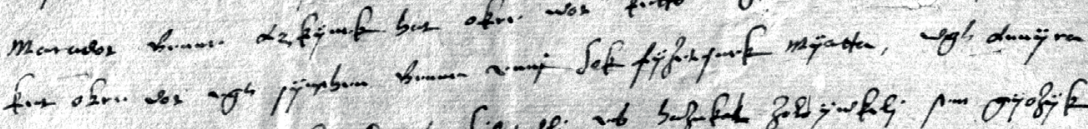

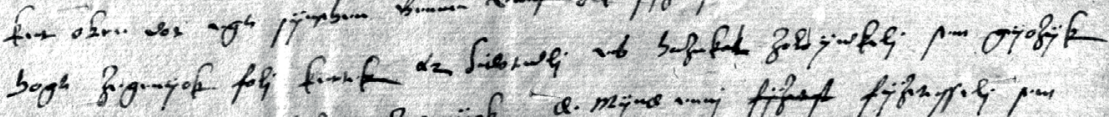

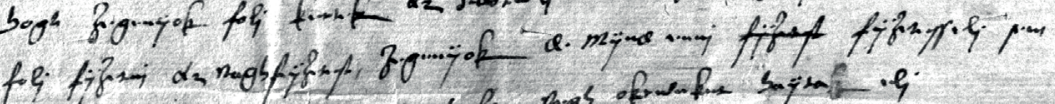

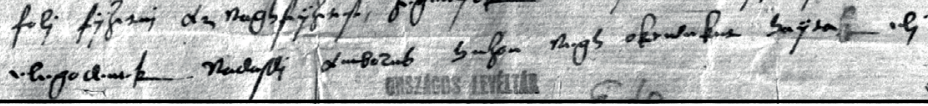




\section{I.5.}

Ete, 1562 elött. Etei jobbágyok levele

Mj kÿk wagwnk Etheÿek Zegenÿ megh nÿomorodot nepek kózónetwnket es orókke valo zolgalatwnkat Irÿwk Mj te nagsagodnak Mÿnt Mj nagh: kegelmes wronknak: Touaba megh ertottwk az nagh lewelebolj az nag: parancholatÿat holot te nag: azt paranchollÿa Mj nekwnk hogh ez el mwlt eztendobe menj fÿzeteswnk vot azokat te nag: tudassara adnoÿwk es te nag: bekuldÿwk Irwan Registrumba, Mj kezok wagwnk az nag: parancholatÿanak engednj mÿnd órókkę: Touaba ezt te nag: tudasara adÿwk Legh elozor Jwe Reank nagh gaspar Reank Izenÿe hogh ha megh nem sarcolwnk nekj tehat Reank Jw es varaswnkat megh egetj es megh dwlÿa annak wtanna valamolÿet kaphat bennwnk mÿnd zablÿara hanÿa nagh gaspar vot Raÿtwnk ket zaz harmÿnc ót forjntot ket Istamet Mentet baranÿ bórelj belotet negh ezwst horgot Ra, ket koponÿegot, ${ }^{1}$ nagh sebostÿen Rank Jwe azwtan

Ilÿen fenÿogetesselj fenÿogetot, azÿs vot Raÿtwnk nÿolc heÿan zaz forjntot az megh ket koponÿegot ket fekot Jot, annakwtanna Ismet Rank Jwe balog tamas almassi gwrkowalj varaswnkat megh dwlak es meg egetek votek Raÿtwnk zaz tÿz forjntot egh ezust horgot, fwrottas domotor es kalmar andras Rank Izenenek <ak> azok vottek raÿtwnk ótwenÿ negh forjntot, annak vtanna Ismet Rank Jwenek Morsolo mate es fekete bence, maÿor amborus azok vottek Raÿtwnk hwzonót forjntot ket Ruhara valo Istamet poztot egh Istamet dolmant Sarkozi boltissar vot Raÿtwnk nÿolc forjntot Im latÿa te nagh: Minemw nÿagh sarcolassalj sarcoltatanak ez el mwlt eztendobe Mÿnket es menj sok nÿomo-rwsagot tottek Raÿtwnk, hogh Imaran az varasnak Job Reze el puztwlt es azkÿk Raÿta laknakÿs annÿra Jwtattak oket hogh az kÿnek tÿz okre vot negh maradot benne azkÿnek hat okre wot ketto vagion benne azkÿnek ket okre vot egh sÿnchen benne ennj Sok fÿzetesnek mÿatta, wgh annÿra hogh zegenÿok folj kertek az Sidotwlj es hazukal ${ }^{2}$ zoloÿwkelj ${ }^{3}$ sem gÿozÿk folj fÿzetnj az nagh fÿzetest, zegenÿok de mÿnd ennj <fÿzetest> fÿzetesselj sem elegodenek nadasdj amborus huzon negh okrwnket haÿta $<\mathrm{k}>\mathrm{elj}$

\footnotetext{
${ }^{1}$ Két szónyi interlineáris betoldás, jelekkel a helyére utalva.

${ }^{2}$ Az $l t$-böl javított betünek látszik.

${ }^{3}$ A szó második $o$-ja fölött szándéktalannak tünő tollvonás van.
} 


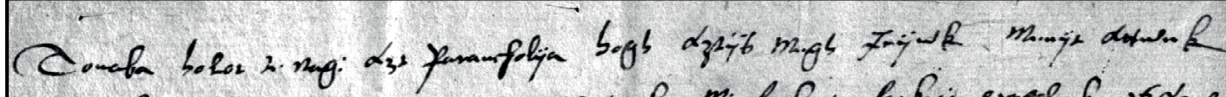

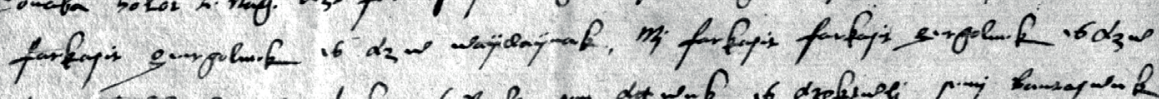

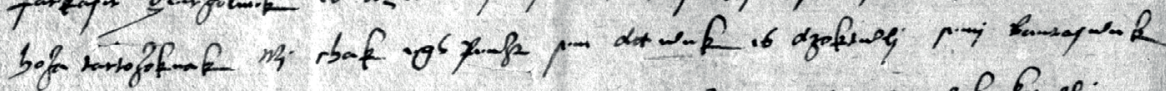

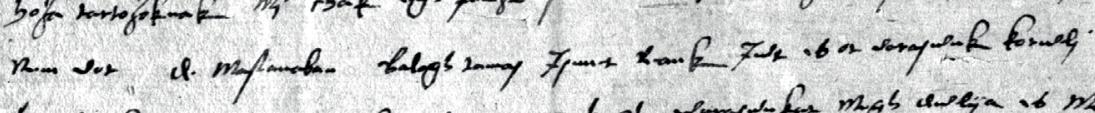

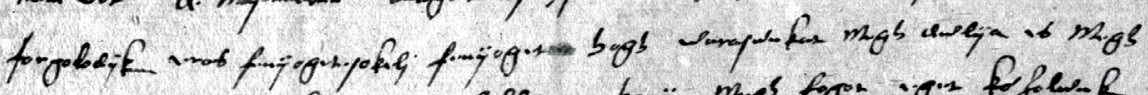

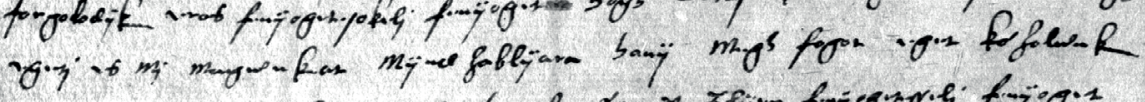

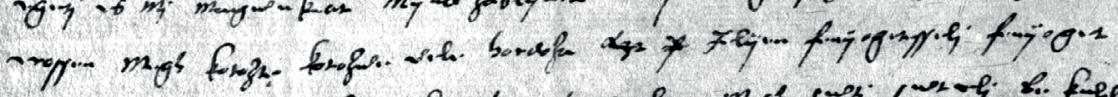

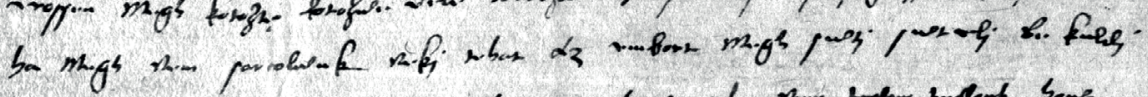

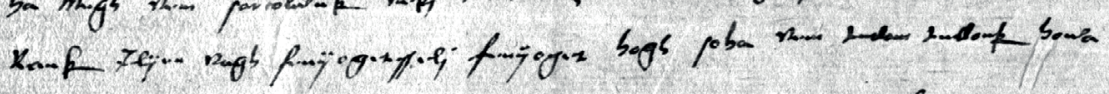

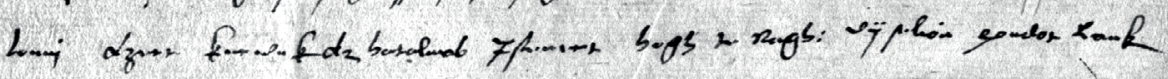

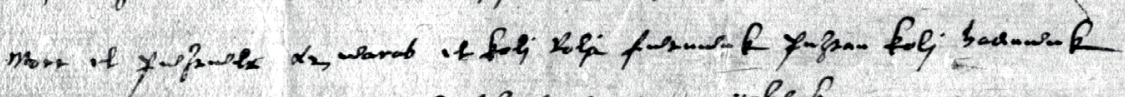

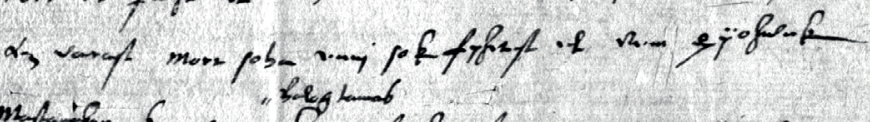

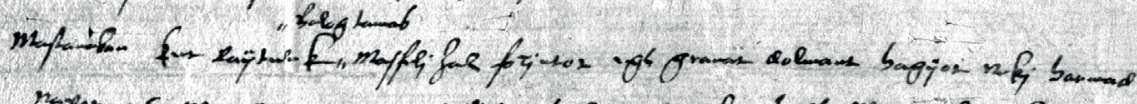

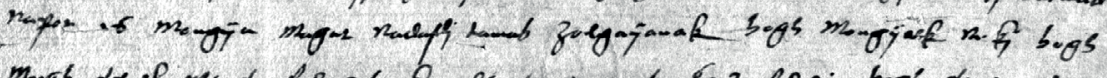

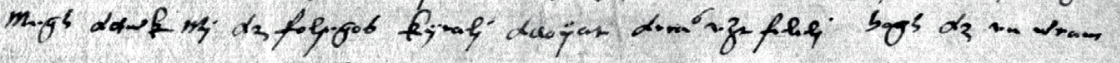

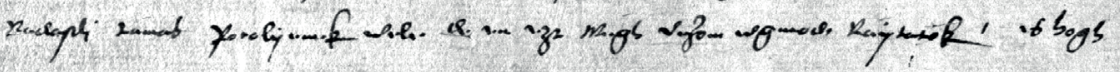

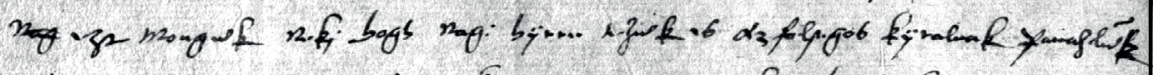

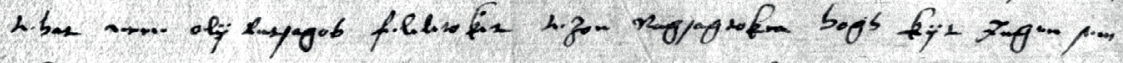

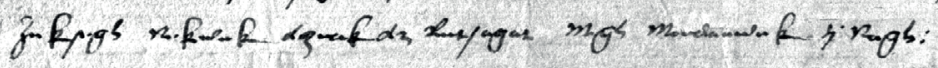


Touaba holot te nag: azt parancholÿa hogh aztÿs megh Irÿwk Menÿt attwnk farkasit gergolnek es az w waÿdaÿnak, Mj farkasit farkasit gergolnek es az w hoza tartozoknak Mj chak egh penzt sem attwnk es azoktwlj semj bantaswnk nem vot de mastanaban balogh tamas Ismet rank Jwt es ot varaswnk korwlj forgolodÿk eros fenÿogetesokelj fenÿoget ${ }^{4}$ hogh waraswnkat megh dwlÿa es megh egetj es mj magwnkat mÿnd zablÿara hanÿ megh fogot eget kózolwnk erossen megh kotozte kotozwe vele hordoza < azt p > Ilÿen fenÿogetesselj fenÿoget ha megh nem sarcolwnk nekj tehat az embort meg swtj swtelj ${ }^{5}$ be kuldj Rank Ilÿen nagh fenÿogetesselj fenÿoget hogh soha nem $<$ tudom $>$ tudonk $^{6}$ howa lennj azert kerwnk az hatalmas Istenert hogh te nagh: vÿselion gondot Rank mert el pwztwl $<\mathrm{t}>$ az waras el kolj Rolja fwtnwnk puztan kolj hadnwnk az varast mert soha ennj sok fÿzetest el nem gÿozwnk

Mastanaban ker Raÿtwnk balog tamas ${ }^{7}$ masfelj zaz forjntot egh granat dolmant hagÿot nekj harmad napot es mongÿa magat nadasdj tamas zolgaÿanak hogh mongÿwk nekj hogh Megh attwk mj az folsegos kÿralj adoÿat arra ó ${ }^{8}$ ezt felelj hogh az en wram nadasdi tamas porolÿenek wele de en ezt megh vezom wgmod ${ }^{9}$ Raÿtatok ${ }^{10}$ es hogh $<$ nag> ezt mongwk nekj hogh nag: hÿrre tezwk es az folsegos kÿralnak panazlw̄ ${ }^{11}$ tehat erre olÿ Rutsagos feleletoket tezon nagsagtokra hogh kÿt Ingen sem zuksegh nekwnk aznak az Rutsagat megh mondanwnk tj nagh:

\footnotetext{
${ }^{4}$ A szó után törlés nyoma látszik.

${ }^{5} \mathrm{Az} e$ olvasata nem kétségtelen.

${ }^{6} \mathrm{~A} d$ javított betü.

${ }^{7}$ Két szónyi interlineáris betoldás, jellel a helyére utalva.

${ }^{8}$ A szó interlineáris betoldás.

${ }^{9}$ A szó utáni vonás szándéktalannak tünik.

${ }^{10}$ A szó után talán tévesen elkezdett betủ látszik.

${ }^{11} \mathrm{~A} k$-n esetleges javítás nyomai látszanak
} 


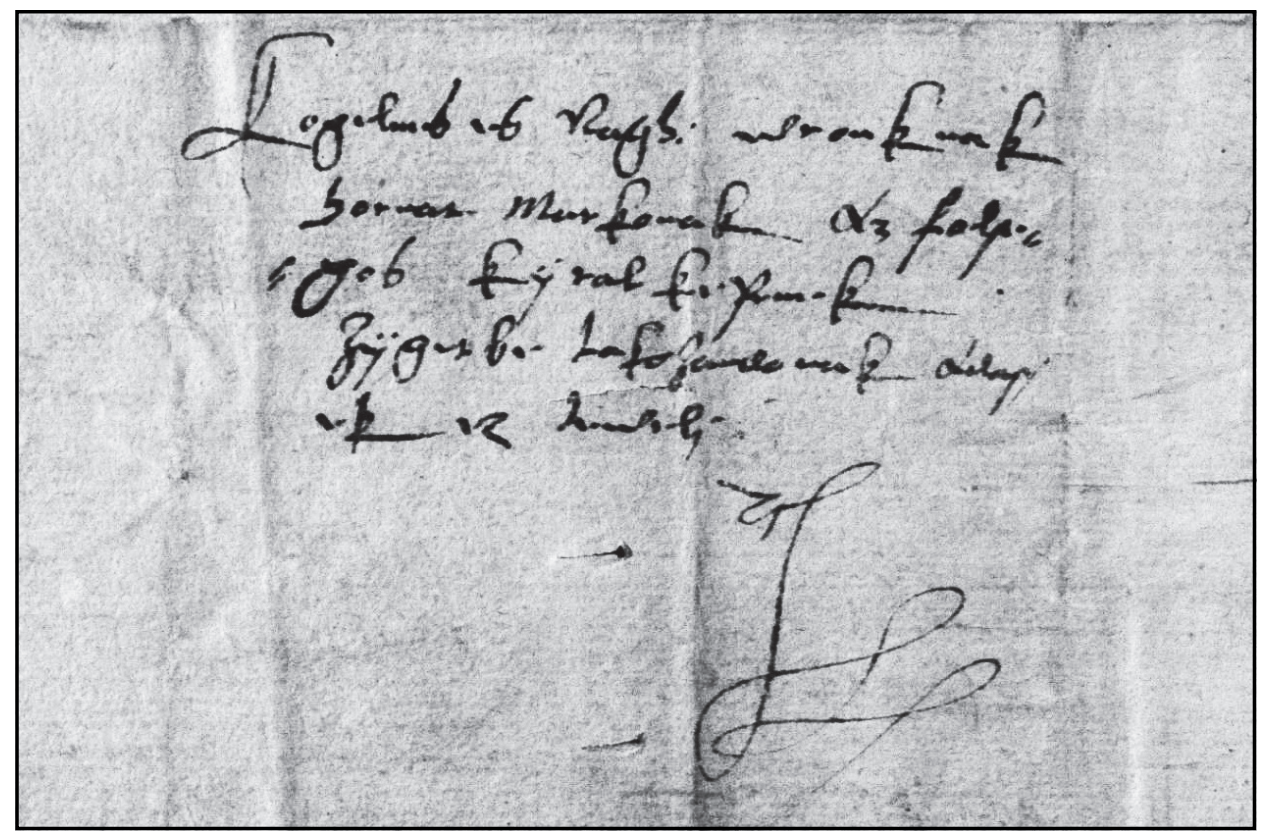


Kívül:

Kogelmes es Nagh: wronknak

horuat markonak az folse-

-gos kÿral kepenek

zÿgetbe lakozandonak adass

ek ez lewelj

etc 


\section{4. aug. 13. wor} 1 am ar hagmifin ez ofviy dimi Ami mi firksmam Comninrim: nj lwam wagjon

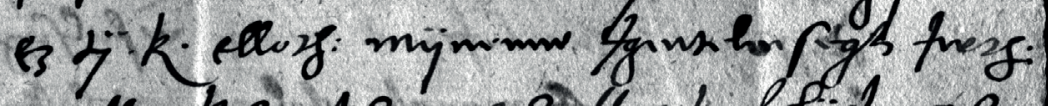
vealla kozivoin as gellovek fljol as

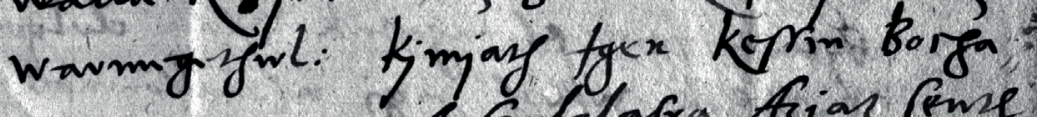
for as warmige is ambalafra tisjas fing

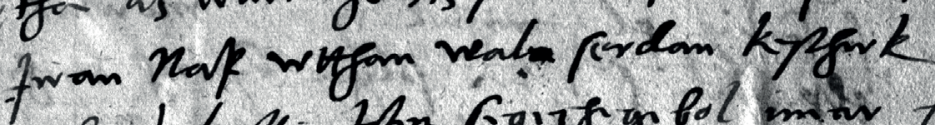

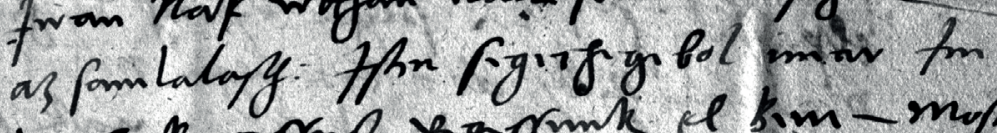

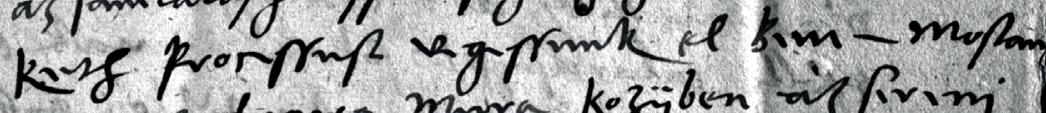
thfi on diawa mura kezjem as frim

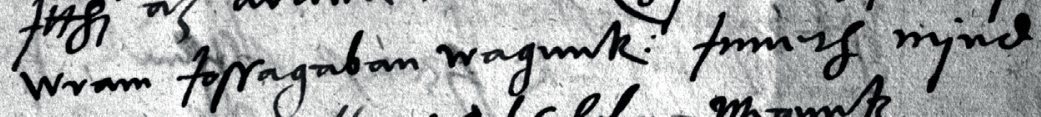
farapg as salla fulfpho-mgmt.

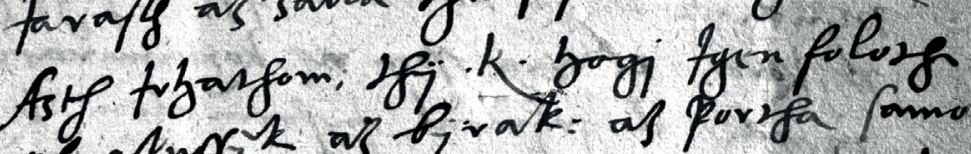

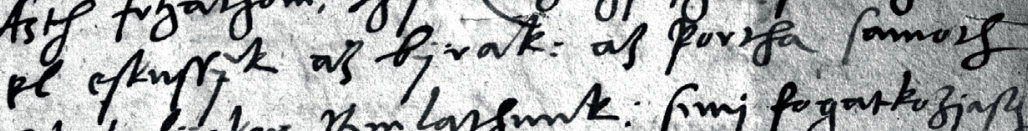

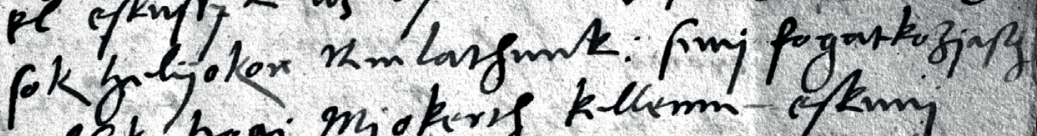
koffok gogi mjokery kllim k/2mi

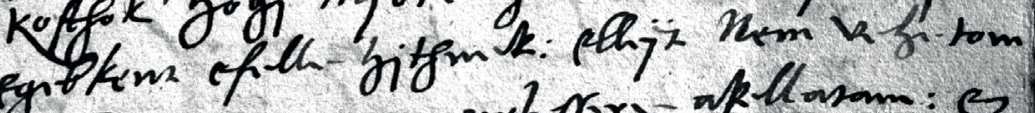

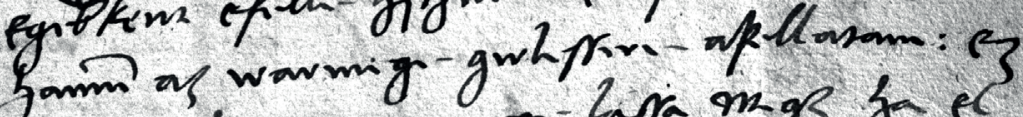
okvef fogi as wowmy-lapa mags fa oc kd vamink of h- Gomp smarikenk

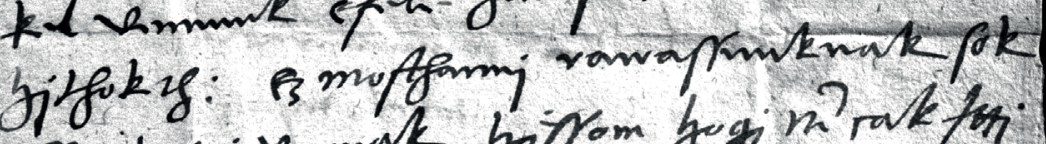

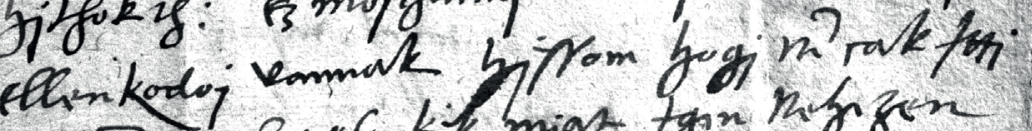

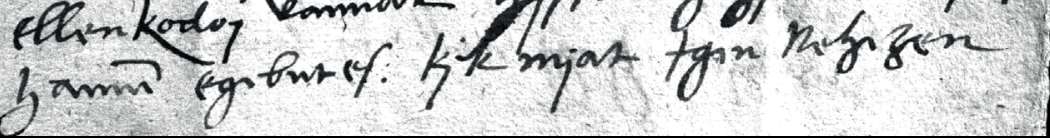




\section{I.6.}

Letenye, 1564. VIII. 13. Hosszútóti János levele.

Reverendissime ac Magnifice et Egregj dominii seruici mei perpetuam Comendationem: Nÿlwan wagÿon

ez tÿ $\cdot \mathrm{k} \cdot$ elloth: mÿnemw Igentelensegh Jwth: walla kozÿnkben az zellerok felÿol az warmegethwl: kjmjath Igen kessen Bocha-tha az warmege Az samlalasra Azjaz senth Iwan Nap wtthan walo ${ }^{1}$ serdan kesthwk az samlalasth: Isten segechegebol imar Im keth processust vegessunk el Bene Mostan Itthj az drawa Mura kozÿben az serenj Wram Jossagaban wagunk: Inneth mjnd Jarasth az zalla thulso felre Megunk

Azth Irhathom ${ }^{2}$ thÿ $\cdot \mathrm{k} \cdot$ hogj Igen folothe el eskussÿk az bÿrak: az portha samoth sok helÿokon Nem lathunk: semj fogatkozjasth kosthok hogj Mj okerth kellenne eskunj egebkent efelle hjthnek: elleÿt Nem vehetom hanne az warmege gwlessere apellatam: ez okerth hogj az warmege lassa Megh ha el kel vennunk efele hamis embereknek hjthoketh: ez mosthannj rawassunknak sok ellenkodoj vannak hjssom hogj ne cak Ittj hannē egebutes: kjk mjat Igen Nehezen

\footnotetext{
${ }^{1}$ Az $o$ javított betü, feltehetően $a$-ból.

${ }^{2}$ A szó utáni vonás szándéktalan lehet (ilyen tagolójelet nem használ a levélíró).
} 


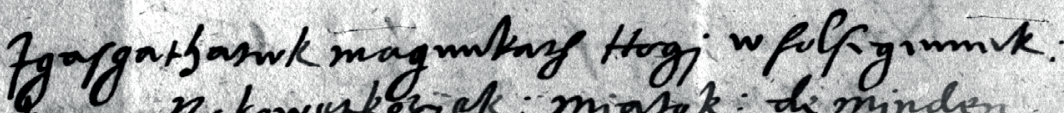

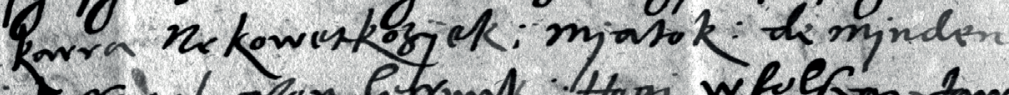
ofopregal afon exprumk. Hog wfoefgr-fonara hymk: A monak dolgat languk fogi as

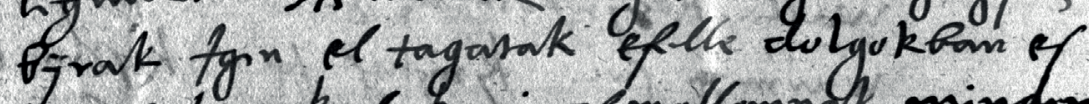

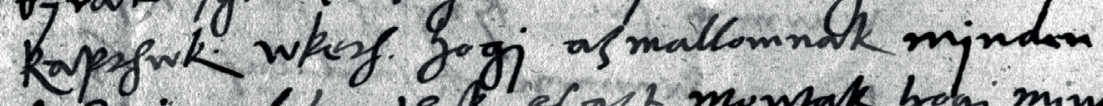

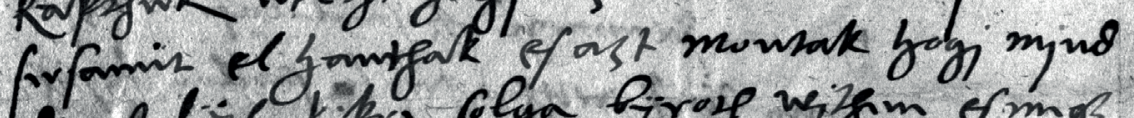

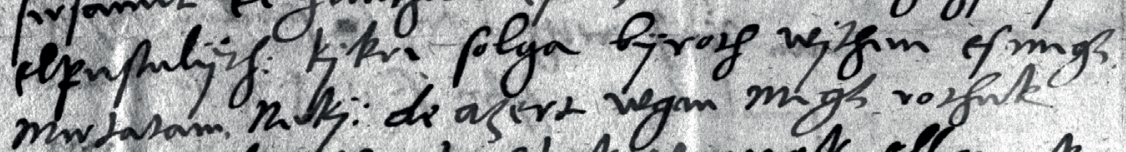
thll mlardfayok pkak vamak elhmmik.

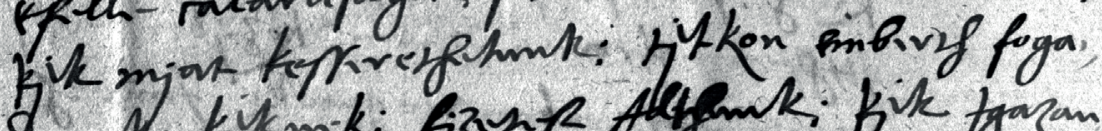

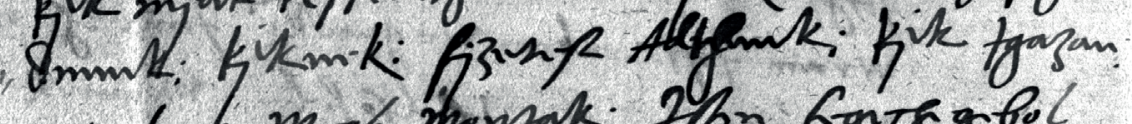
mindink magh thasisak: 7/hn fgirggbol mikeron etwigipom os kemmmorioy minder dogymul ifformatom $k$ : is

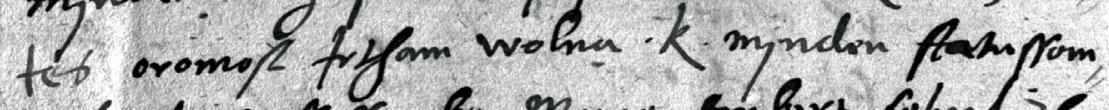
, vil di-an fopromba mama embirs pugntiff $x_{m}$ baljaltam ote 3 mirif nem foram \&s

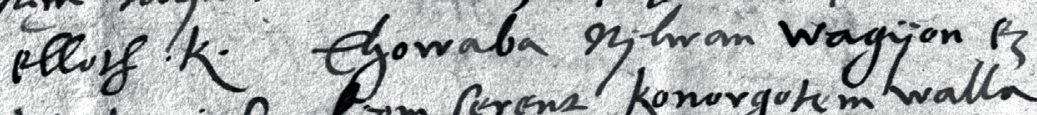
$k$ yogi frometom perans konorgokem walla 1 . ogi mikevon as palla yulpo fho koulunk. a 3 rommmirariora mel belek tgan flelmb torok mjayg: Kergin nom minuk: iarma: Gogi wallamy tgim fan lowagalf 
Igasgathatwk magunkath Hogj w folsegennek: karra Ne kowetkozÿek: mjatok: de mjnden okossagal azon lessunk: Hogj w folsege Jawara legunk:

Az monak dolgat lathuk hogj az bÿrak Igen el tagatak efelle dolgokban es kapthwk wketh hogj az mallomnak mjnden sersamit el hanthak es azt montak hogj mjnd elpustulÿth: kjkre solga bÿroth wjthem es megh Mwtatam nekj: de azert wgan megh rothwk efelle calardsagok: ${ }^{3}$ sokak vannak ellenunk kjk mjat kesserethetunk: tjtkon emberth foga-dunnk: kjknek: fjzetest Adthunk: ${ }^{4}$ kjk Igazan mjndent Megh montak: Isten segechegebol mjkoron el wegessom az konumeracioth mjnden dolgajmrul Informalom :k: ez ello-tes oromost Irtham wolna $\cdot \mathrm{k} \cdot$ mjnden statussom-rul de en possomba menno embert sohuljth Nem taljaltam: oka ez mjerth Nem Irtam ez elloth $\cdot \mathrm{k} \cdot$

Thowaba Njlwan wagÿon ez :k: hogj semeljom serent konorgotem walla :k: hogj mjkoron az salla thulso felre kerulunk: az connumeraciora Mel helok Igen felelmes torok mjath: kochjn Nem merunk: iarnja: hogj wallamj egjnehan lowagoth

\footnotetext{
${ }^{3}$ A tagolójel megléte nem kétségtelen; esetleg $j$ kezdeményének is felfogható.

${ }^{4}$ A th betükapcsolat valószínüleg $u$-ból van javítva.
} 

gationfogal fowriak is oy tordak fd. Cay pila fellfsommb kinorgotem walle ffik: jugi fwhomfarmivlasut $k$. jugi,

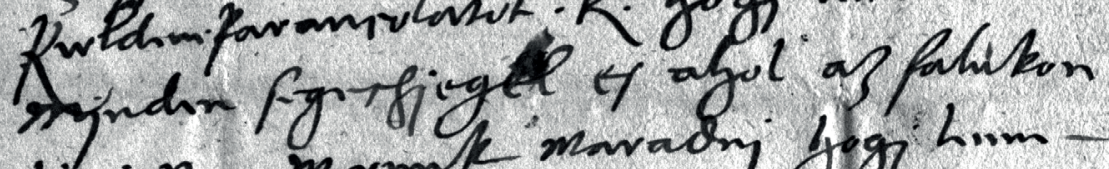
fin $\mathrm{nm}$ mrmk madry gig, fllaprine as weowalesom:

Aswr-fin towia mgs of:k: kulfy \$ hwit hesmint fons loving nak vesfon wall vaparnaf. 5 is t

fowalaf wowok tfo k. plgaja

Hofsutol.

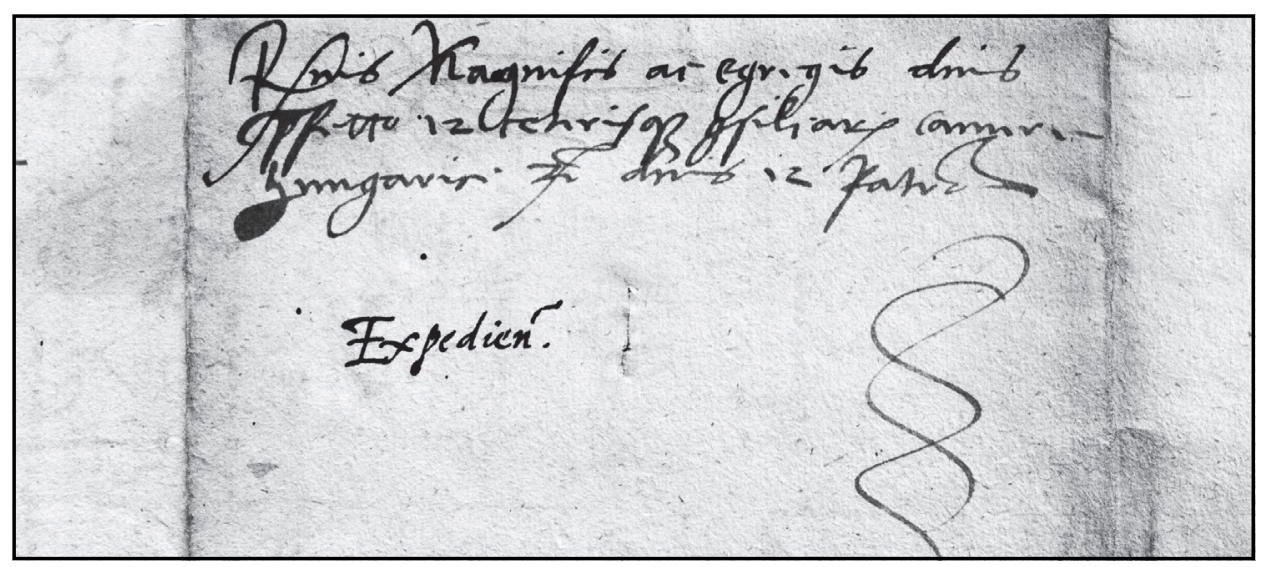


fogadnek melem kjk melleth ennes Batorsagosban Jarhatnek: merth Igen gakortasagal Jarnak kj az torokok Ide az salla felle

Azonnes konorgotem walla thj :k: hogj az tjstartoknak: az wegh warakban Kwldene parancolatot $\cdot \mathrm{k} \cdot$ hogj lennenek mjnden segechjegel ${ }^{5}$ es ahol az falukon kjnj Nem Merunk maradnj hogj lenne sallassunk az warakban :etc:

Az wristen $\operatorname{tarca}^{6}$ Megh the :k: koljth Ez lewel lethenerul sent lorjnch nap vtthan wallo vassarnap. 1564

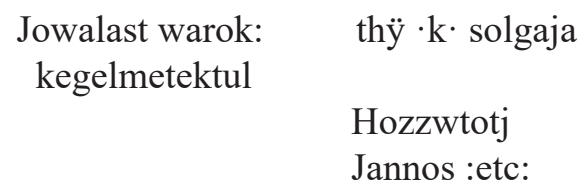

Kívül:

Reverendis Magnificis ac egregis dominis prefecto et ceterisque consiliariis Camere hungaricie etc dominis et patronis

\section{Más kézzel írva:}

\section{Expediendum.}

\footnotetext{
${ }^{5}$ A szó végi két betü tintafoltos (esetleg javítás nyomát viseli).

${ }^{6} \mathrm{~A} c$ a-ból javított betü.
} 
E 41 - 1573 No. 38 .

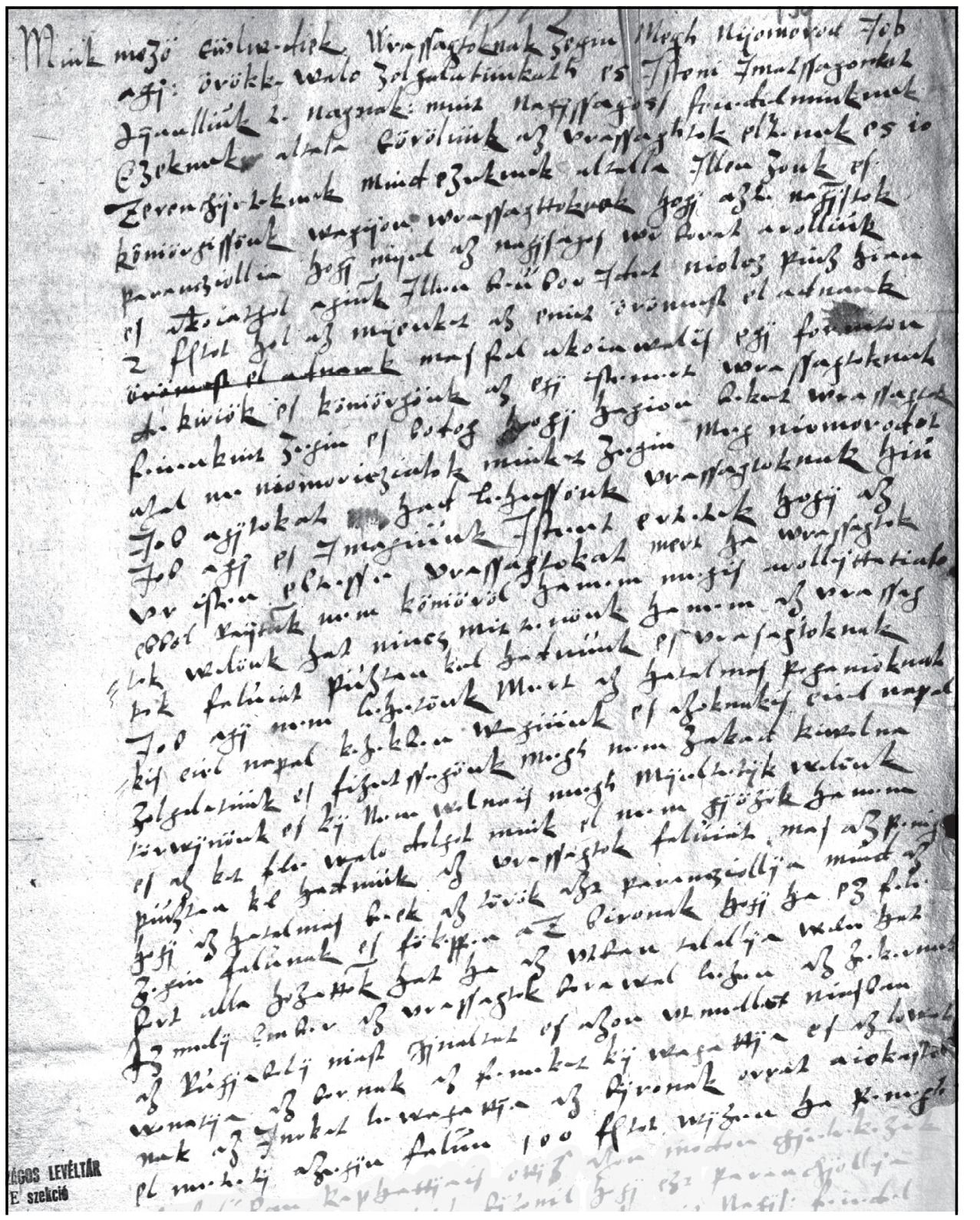




\section{I.7.}

Nagyölved, 1573. XI. 13. Nagyölvedi jobbágyok levele.

Mink mezö Ë̈lwediek Wrassagtoknak Zegin Megh nÿomorod Job agj: örökke walo zolgalatünkath es Isteni Imatssagonkat Aÿanlliŭk te nag:nak: mint nagÿssagoss feiedelminknek Ezeknek $<$.> altala Eörölünk az vrassaghtok eltenek ${ }^{1}$ es io Zerenchÿeteknek mind ezeknek altalla Illen zonk es köniörgissönk wagÿon wrassagttoknak hogÿ az te nagÿstok parancziollia hogj mÿel az nagÿsagos wr borat arolliŭk es Akoiathol ${ }^{2}$ agiūk Illen beü bor Idet niolcz pinz hian 2 florentot hol az mÿenket az eniet örömest el adnank $<$ örömest el adnank> mas fel akoiawalis egÿ forinton ${ }^{3}$ de kiriök es köniörgönk az egÿ istenert wrassagtoknak feienkint zegin es bodog hogÿ ${ }^{4}$ hagion beket wrassagtok azal ne niomoricziatok minket zegin Meg niomorodot Jobagÿtokat $<$.. $>$ had lehessönk vrassagtoknak hiŭ Jobagÿ es Imagiünk Istent ertetek hogÿ az vr isten eltesse vrassagtokat mert ha wrassagtok ebböl Raÿtūk nem köniöröl hanem megis arollÿttatiato -tok welönk hat nincz mit tenönk hanem az vrassag tok falŭiat püztan kel hadnünk es vrasagtoknak Jobagÿ nem lehetönk Mert az hatalmas poganioknak -kis eiel napal kezekben wagiünk es azoknakis eiel napal zolgalatünk es fizetssegönk Megh nem zakad kiwolna törwÿnönk es kÿ Nem wolnais megh Mÿeltetÿk welönk es az ket fele walo dolgot mink el nem gÿözök hanem püztan kel hadnünk az vrassagtok falüiat: mas az penig hogÿ az hatalmas beek az török azt parancziollÿa mind az zegin falŭnak es fökeppen az bironak hogÿ ha ez fele bort alla hozattok hat ha az vtban talallÿa wele hat $A z^{5}$ melÿ ember az vrassagtok borawal lezen az zekernek az rŭgÿabolÿ niast chjnaltat es azon vt mellet niasban wonatÿa az bornak az feneket kÿ wagattÿa es az lowak nak az Inokat le wagattÿa az bÿronak orrat aiokastol el metetÿ azegÿn falün 100 florenorum wÿzen ha penegh

\footnotetext{
${ }^{1}$ A $t$ más betünek indult.

${ }^{2}$ A levélíró a $k$-t az $A$ betüszárára írja rá, a szövegben két helyen is.

${ }^{3}$ A szó közepén tintafolt látszik.

${ }^{4}$ A szó elején tintafolt látszik.

${ }^{5} \mathrm{Az} A$ javított betü.
} 

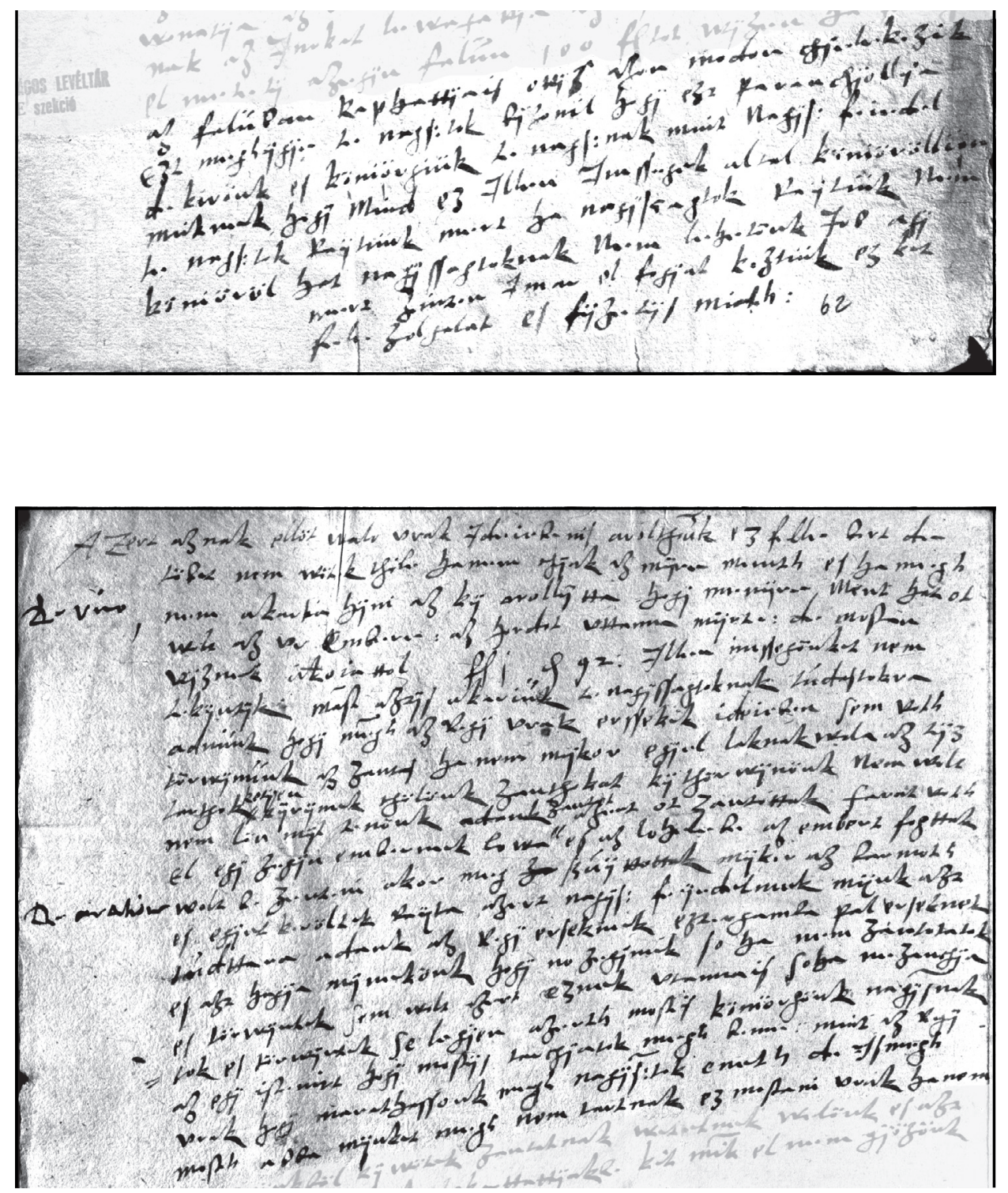
az falüban kaphattÿais ottjs ${ }^{6}$ azon modon chÿelekezik

Ezt meghÿgÿe te nags:tok bÿzonil hogÿ ezt paranchÿollÿa

de kirönk es köniörgiük te nags:nak mint Nagÿs: feiedel

müknek, hogÿ Mind ez Illen Imssegek altal köniörölliön

te nags:tok Raÿtünk mert ha nagÿssagtok Raÿtünk nem

köniöröl hat nagÿssagtoknak Nem lehetönk Jobagÿ

mert zinten Imar el fogÿatkoztünk ez ket

fele zolgalat es fÿzetÿs miath:

Azert aznak ellöt walo vrak Ideiebenis arolthiūk ez felle bort de töbet nem wötek thöle hanem chÿak az mÿre menth es ha megh nem $^{7}$ akarta ${ }^{8}$ hÿni az kÿ arollÿtta hogÿ menÿre Ment hat ot wolt az vr Embere: ${ }^{9}$ az hordot vttanna mÿrte: de mostan vÿznek Akoiattol florenus 1 denariorum 92: Illen imssegönket nem tekÿntÿk. māst aztÿs akariük te nagÿssagtoknak tŭdastokra adnünk hogÿ megh az Regÿ vrak erssekek ideieben ${ }^{10}$ sem voth törwÿnünk az zantas ha nem mÿkor egÿel laknak wala az tÿz tarthok ketÿen ${ }^{11}$ kÿrÿnek thölönk zanthokat kÿ thörwÿnönk nem wolt nem lön mÿt tenönk adank zantot ${ }^{12}$ azert ot zantottak farat voth el egÿ zegÿn embernek lowa es az lo helebe az embert fogttak wolt ${ }^{13}$ be zantani akor meg <za> szüÿttottak mÿkor az barmoth es egÿet keröltek raÿta azert nagÿs: feÿedelmek mÿnk azt tŭdttara adank az Regÿ erseknek eztergamba pal erseknek es azt hagÿa mÿnekönk hogÿ no zegÿnek soha nem zantotatok es törwÿntek sem wolt azert eznek vtannais soha ne zanchÿa -tok es törwÿntek se legÿen azerth mostis köniörgönk nagÿsnak az egÿ istenirt hogÿ mostÿs tarchÿatok megh benne: mint az Regÿ vrak hogÿ marathassonk megh nagÿs:tok eneth de Ismegh mosth abba mÿnket megh nem tartnak ez mostani vrak hanem

\footnotetext{
${ }^{6} \mathrm{~A} s$ javított betü.

${ }^{7}$ A sor vonalában a bal margón más kéz írásával: „De vino”.

${ }^{8}$ A $t$ i-böl javított betü

${ }^{9} \mathrm{Az}$ e javított betü.

${ }^{10} \mathrm{Az}$ első $e$ javított betü.

${ }^{11}$ A szó jelölt interlineáris betoldás.

${ }^{12}$ A szó jelölt interlineáris betoldás.

${ }^{13}$ A sor vonalában a bal margón más kéz írásával: „De aratione”.
} 


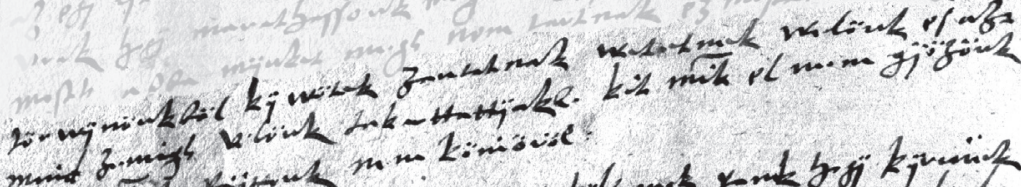

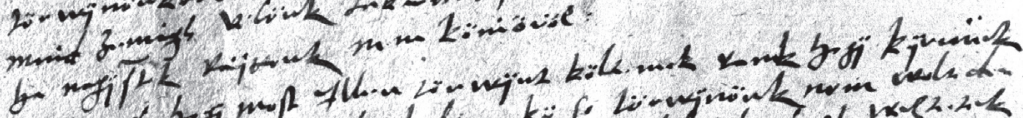

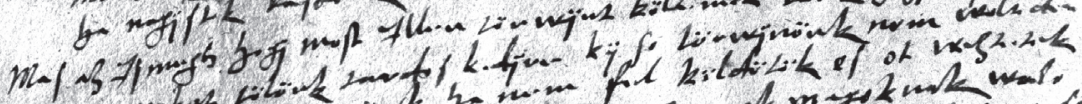

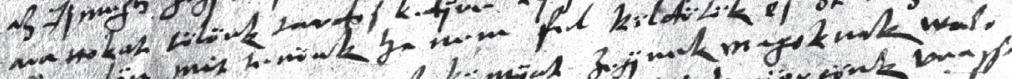

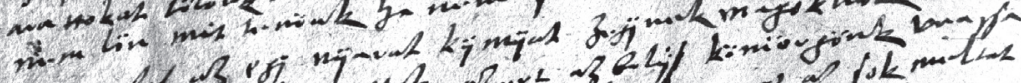

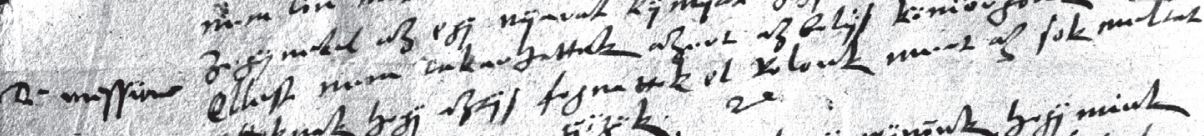

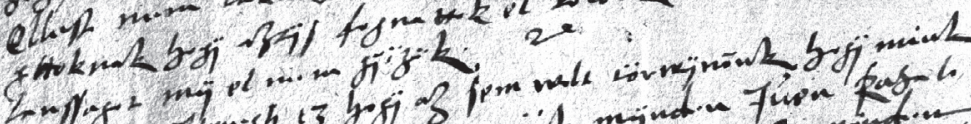

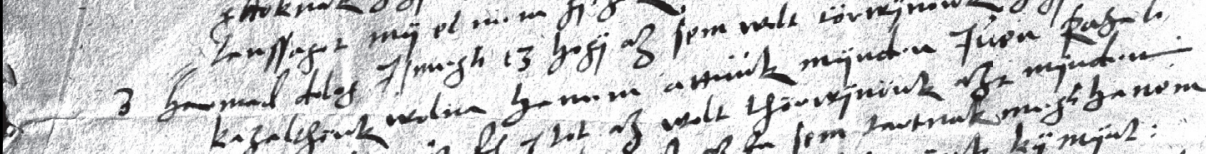

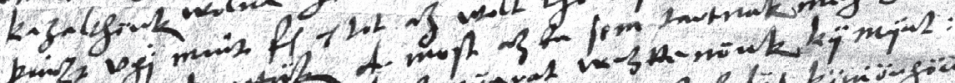

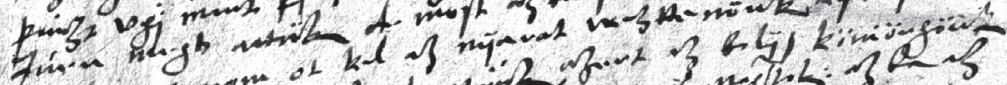

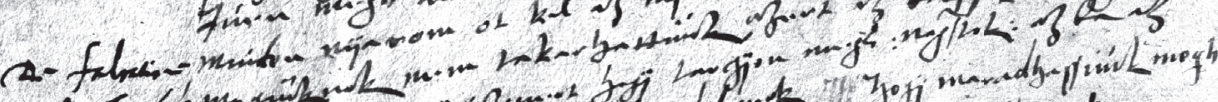

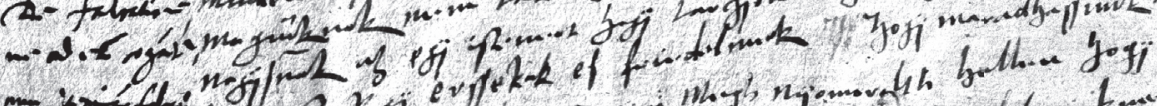

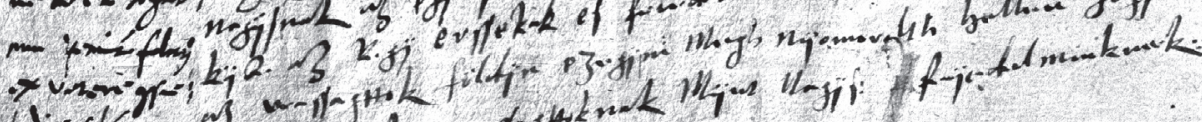

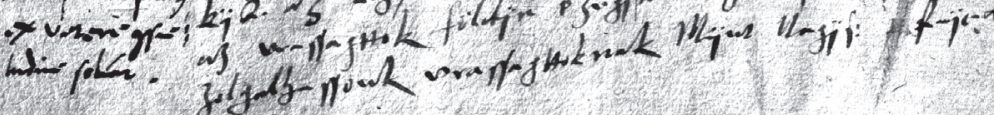

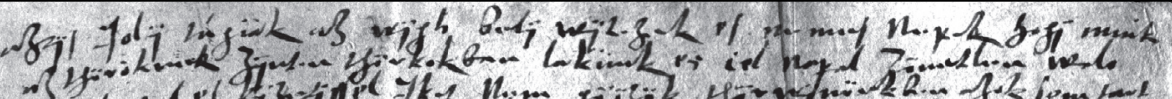

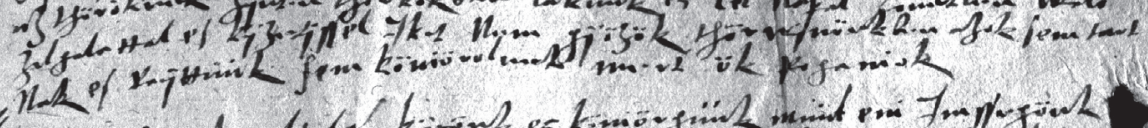

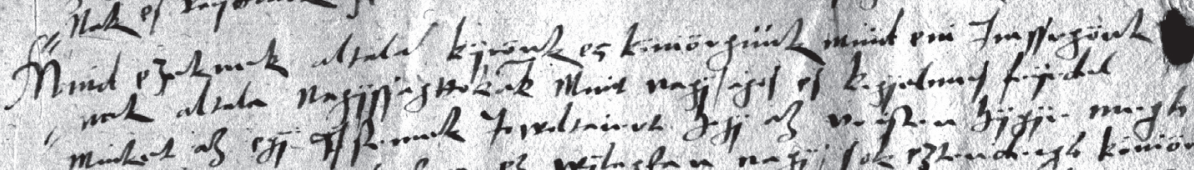

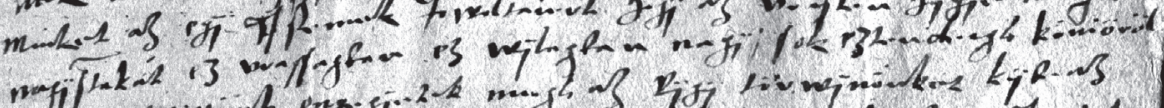

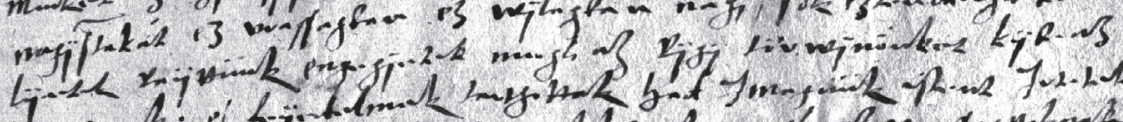
$j_{j}$.

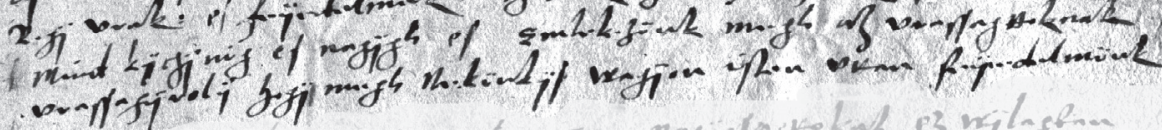


törwÿnönkböl kÿ wötek zantatnak wetetnek welönk es azt mind zemigh velönk takarttattÿakbe kit mik el nem gÿözönk ha nagÿstok raÿtonk ${ }^{14}$ nem köniöröl:

Mas az Ismegh hogÿ most Illen törwÿnt költenek rank hogÿ kÿrniek arattokat tölönk tardos kedÿre kÿ so törwÿnönk nem volt de nem lön mit tenönk ha nem fel köldötök es ot weztetek zegÿnekel az egÿ nÿarat kÿ mÿat zegÿnek magoknak walo Ellest ${ }^{15}$ nem takarhattak azert az bolÿs köniörgönk vrassa gttoknak hogÿ aztÿs fognattok el rolonk mert az sok meltat -lanssagot mÿ el nem gÿözök: etc:

3 harmad dolog Ismegh ez hogÿ az sem wolt törwÿnönk hogÿ mink kazalthönk wolna hanem attünk mÿnden Iŭen kazalo pinzt vgÿ mint florenus 1 tot az wolt thörwÿnönk azt mÿnden Iŭen megh attük de most az ba sem tartnak megh hanem minden ${ }^{16}$ nÿarom ot kel az nÿarat wezttenönk kÿ mÿat: magünknak nem takarhattünk azert az bolÿs köniörgönk nagÿsnak az egÿ istenert hogÿ tarchÿon megh: nagstok: azba az kÿbe az Regÿ erssekek es feiedelmek <...> hogÿ maradhassünk megh az vrassagttok földÿn e zegÿni Megh nÿomorolth hellen hogÿ zolgalhassonk vrassagttoknak Mÿnt Nagÿs: < ..>feÿedelminknek:

aztÿs Jolÿ tŭgiak az wÿgh belÿ wÿtezek es nemes Nepek hogÿ mink az thöröknek zÿnten thörkokban lakünk es iel napal zönetlen walo zolgalattal es kÿzetjssel Iket Nem gÿözök thörwÿnönkben azok sem tart -nak es Raÿttünk sem köniörolnek mert ök poganiok

Mind ezeknek altala ${ }^{17}$ kÿrönk es köniörgünk mind eni Imssegönk -nek altala Nagÿssagttokak Mint nagÿsagos es kegÿelmes feÿedel minket az egÿ Istennek ${ }^{18}$ Jowoltaiert hogÿ az vr isten hÿgÿe megh nagÿstakat ez vrassagban ez wÿlagban nagÿ $<$ s $>$ sok eztendeigh köniöröl lÿetek Raÿttünk engegÿetek megh az Rÿgÿ törwÿnönket kÿbe az Regÿ vrak: es feÿedelmek tarthottak had Imagünk istent Irtetek $<.>$ mind kÿchÿnig es nagÿgh es Emlekezönk megh az vrassagttoknak vrassagÿrolÿ hogÿ megh nekönkÿs wagÿon isten vtan feÿedelmönk

\footnotetext{
${ }^{14} \mathrm{~A} t$ után törölt vagy félbehagyott betü nyoma látszik.

${ }^{15}$ A sor vonalában a bal margón más kéz írásával: „De messore”.

${ }^{16}$ A sorban a bal margón más kézzel írva: „De falcatione ne ad eam cogantur cum [...] falcati ex vetere consuetudine solvant". - Az eam olvasata bizonytalan.

${ }^{17}$ Az utolsó betü után félbehagyott betűkezdemény látszik.

${ }^{18} \mathrm{Az} I$ javított betü.
} 


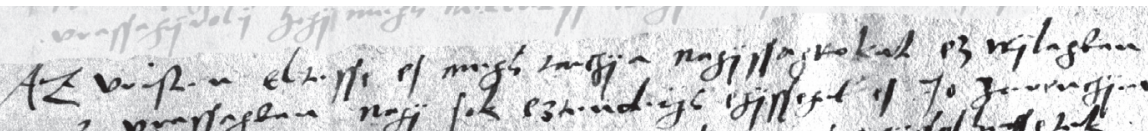

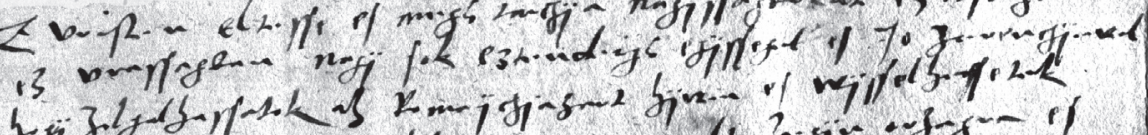

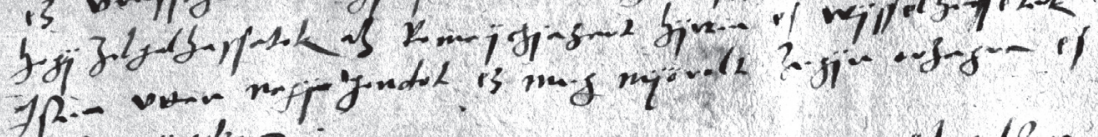

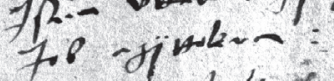

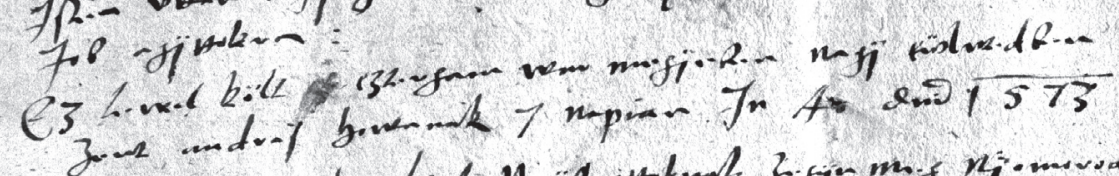

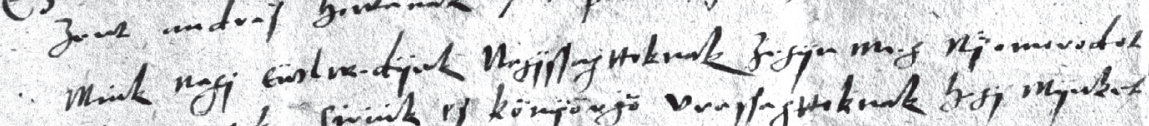

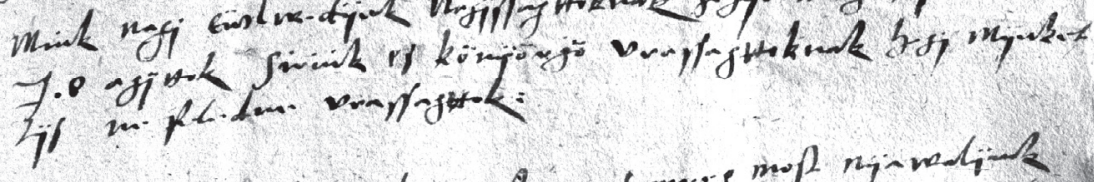

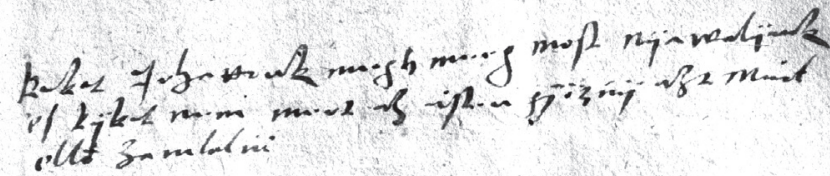

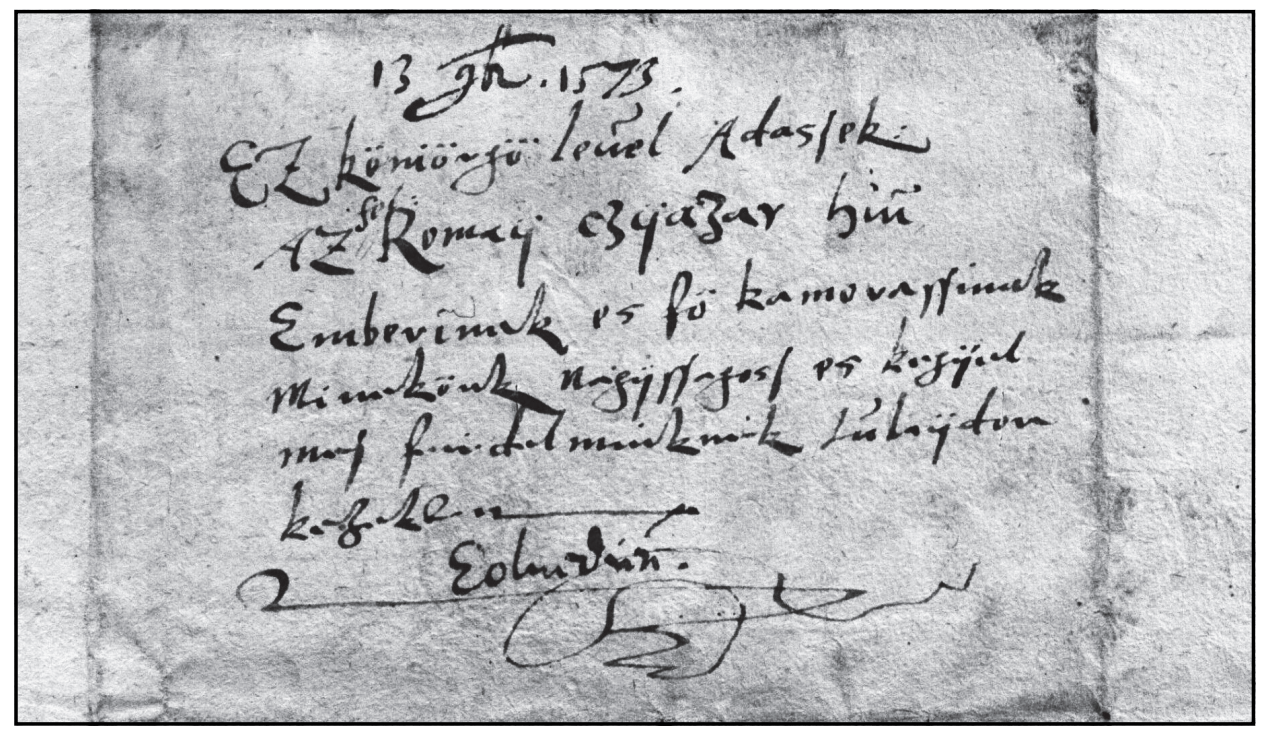


Az vr isten eltesse es megh tarchÿa nagÿssagtokat ez wÿlagban ez vrassagban nagÿ sok eztendeigh egÿssegel es Jo zerenchÿevel hogÿ zolgalhassatok az Romaÿ chjazart hÿuen es wÿsselhessetek Isten vttan nag $\ddot{y}^{19}$ gondot $^{20}$ ez meg nÿörolt zegÿn orzagra es Jobagÿttokra:

Ez lewel költ $<$.> eztergam war megÿeben nagÿ eẅlwedben zent andras howanak 7 napian In Anno domini 1573 Mink nagj eẅlwedÿek Nagÿssagttoknak zegÿn meg nÿomorodot Jobagÿttok siriŭk es könÿörgö vrassagttoknak hogÿ mÿnket tÿs ne feledne vrassagttok ${ }^{21}$ :

kiket Irhattonk megh meeg most nÿawalÿank es kÿket nem mert az isten gÿöznÿ azt mind ellö zamlalni

Kívül:

13 9bris 1573.

Ez köniörgö leŭel Adassek:

Az fel::22 Romaÿ czÿazar hiŭ

Emberinek es fö kamorassinak

Minekönk nagÿssagoss es kegÿel

mes feidelminknek tŭlaÿdon

kezekben

Eolweden

etc

${ }^{19}$ Az $\ddot{y}$ után törölt vagy félbehagyott betü nyoma látszik.

${ }^{20} \mathrm{~A} g$ előtt betükezdet, törlésnyom látszik.

${ }^{21}$ Az első $t$ javított betünek tünik.

${ }^{22}$ A szó interlineáris betoldás. 


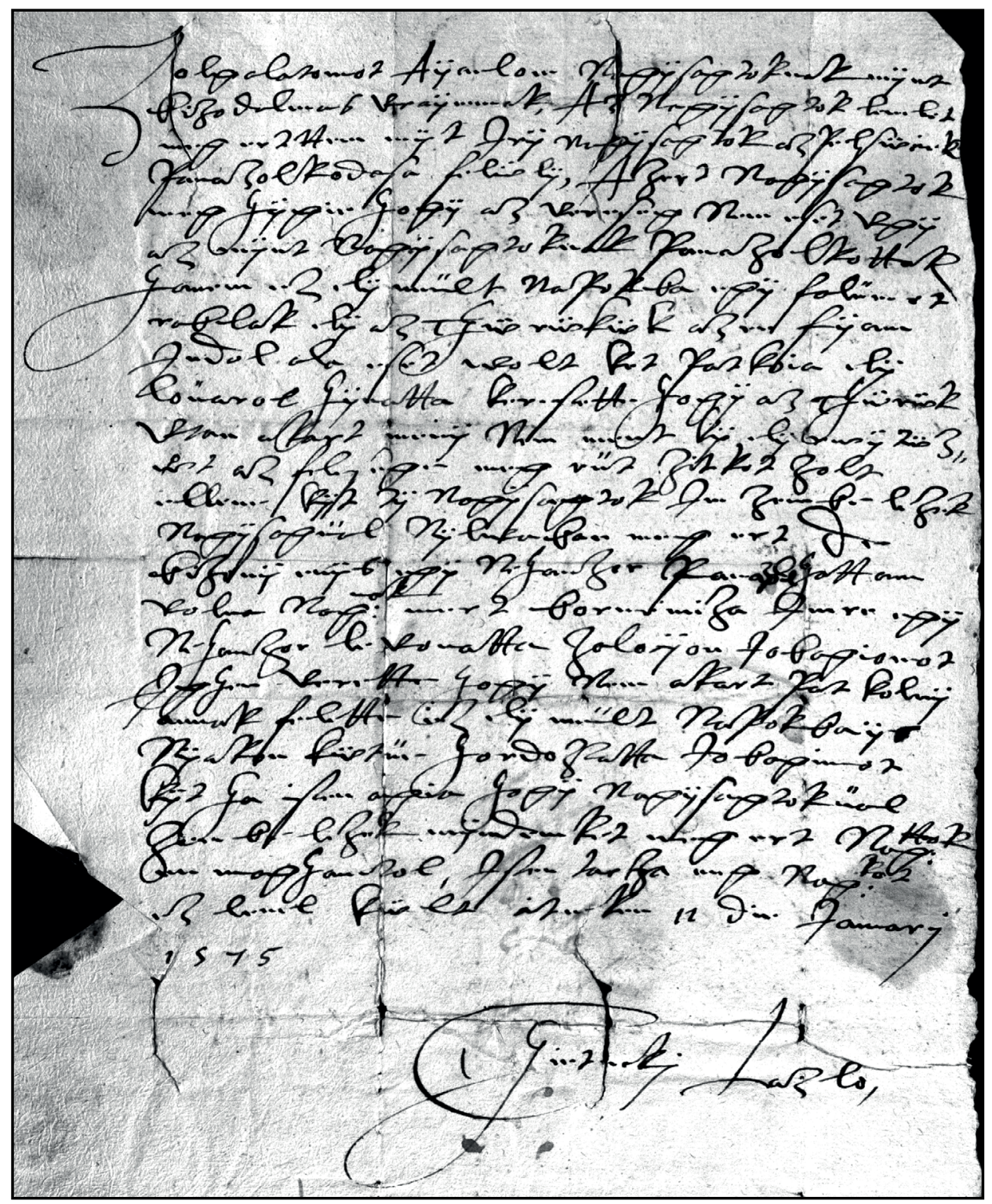




\section{I.8.}

Csetnek, 1575. I. 12. Csetneki László levele.

Zolgalatomot Aÿanlom Nagÿsagtoknak mÿnt

bizodalmas vraÿmmak, Az Nagÿsagtok lewelet meg ertettem mÿt Irÿ nagÿsagtok az pelsẅciek panazolkodasa felẅlÿ, Azert Nagÿsagtok meg hÿgie hogÿ az vereseg Nem eset vgÿ az mÿnt Nagÿsagtoknak panazolkottak hanem ez elÿ mült napokba egÿ falümot rablak elÿ az Thürẅkük az en fÿam Indol ala eset wolt ket patkoia elÿ loüarol hÿuatta kerestette hogÿ az Thẅrẅk Vtan akart menÿ Nem ment kÿ elÿ rwÿtẅz$\mathrm{wt}^{1}$ az felesege meg rüt zitkot zolt ellene kÿt tÿ Nagÿsagtok ${ }^{2}$ Im zembe lezek Nagÿsagüal Nÿlwaban meg ert De bizonÿ enÿs egÿ Nehanzor panazolhattam ${ }^{3}$ volna Nag:nak ${ }^{4}$ mert bornemiza Imre egÿ Nehanzor le vonatta Zolocÿon Jobagiomot Ighen verette hogÿ Nem akart patkolnÿ annak felette ez elÿ mült Napokbaÿs Nÿakon kẅtúe hordoztatta Jobagimot kÿt ha isten agia hogÿ Nagÿsagtoküal zembe lezek mÿndeneket meg ert Nag:ttok ${ }^{5}$ en maghamtol, Isten tarcza meg Nag:kot ${ }^{6}$ ez leuel kẅlt cetneken 12 die Ianuarÿ 1575

$$
\text { Czietnekj Lazlo, }
$$

\footnotetext{
${ }^{1}$ A $w$ helyett talán másik betüt kezdett el a levélíró.

${ }^{2}$ A g-n javítás nyoma látszik.

${ }^{3}$ A szó közepén javítások nyoma látszik; a levélíró a kifelejtett $z$-t valószínüleg rossz helyre kezdte beírni.

${ }^{4}$ A levélíró itt és további két helyen ugyanezen a szón a ragot a rövidítésjel fölé írja.

${ }^{5}$ A rag elején valószínüleg javítás nyoma látszik.

${ }^{6} \mathrm{~A} k$ esetleg javított betü.
} 


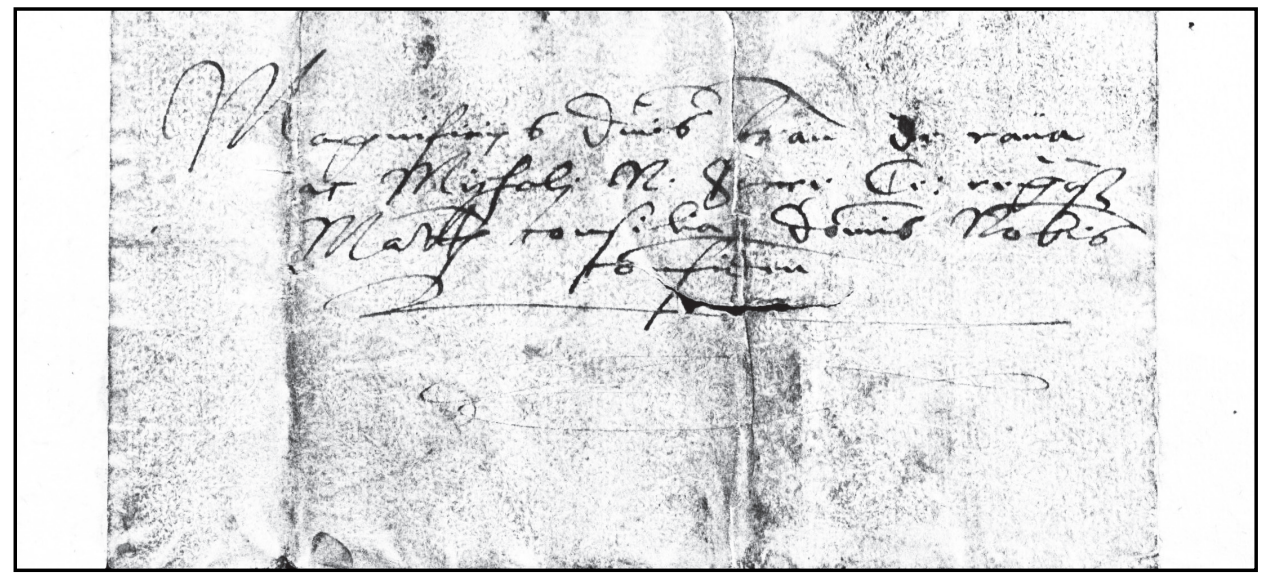


Kivvül:

Magnificÿs Dominis Francisco de raüa ac Michalj N. Sacre Cesaree regieque Maiestatis consiliariis Dominis Nobis dilectis etc 
E $254-1575$. febr. No. 16 .

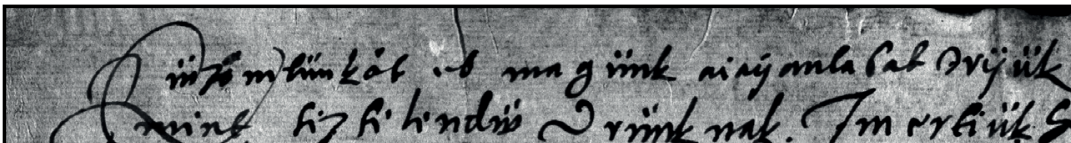
fli Kugill mid if Aria high mi min digng

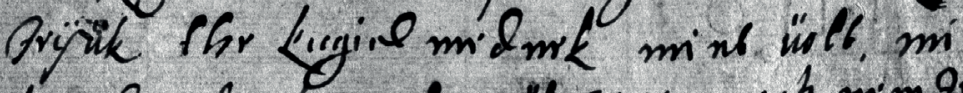
L'giil midmik minl zorullzora migh mim or

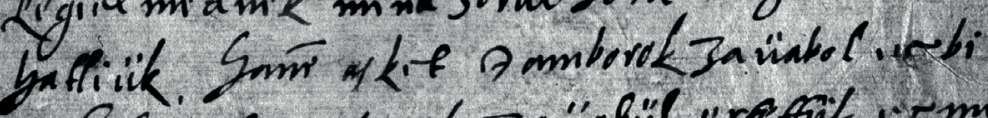

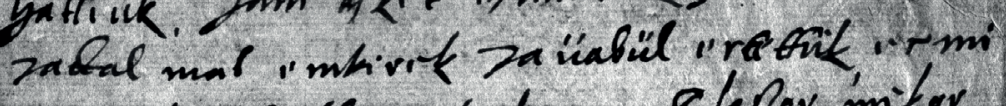
minginkir Sullotink himr. Elopor mikor

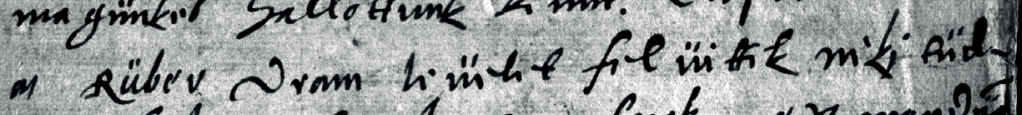
ielik ortmiki ormirnak in monol intiki tanis ki killti of himht. - Lir ki m limiele felin-ffi milfmi

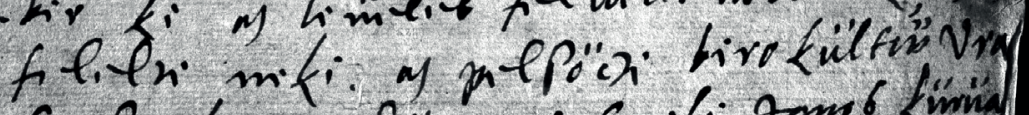

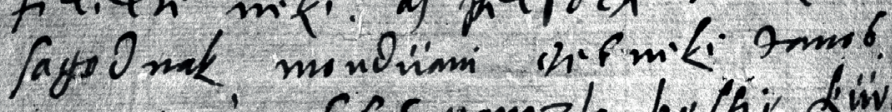
a min is fofor pmizlo biftiv diwura fiank pmislo fofor liffir hlk-k migh rathif high ha ronnkem ingionkel

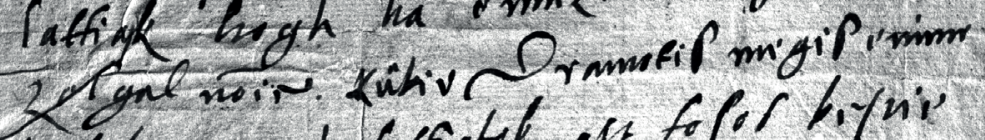
hish migh latiatek aft fofor kivenie hlkg. bopümith allim migh lakéa fakm

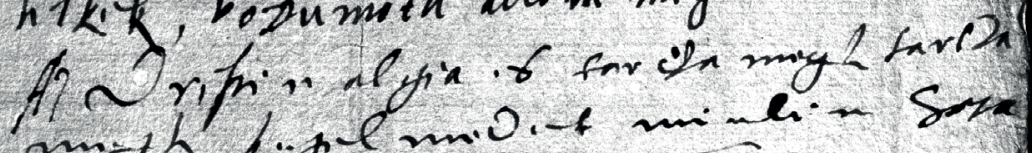

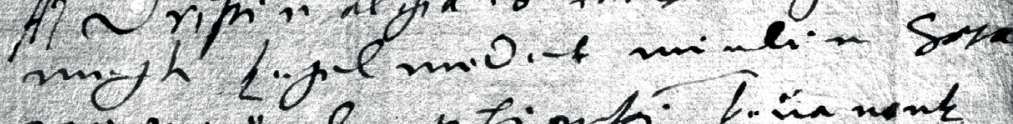

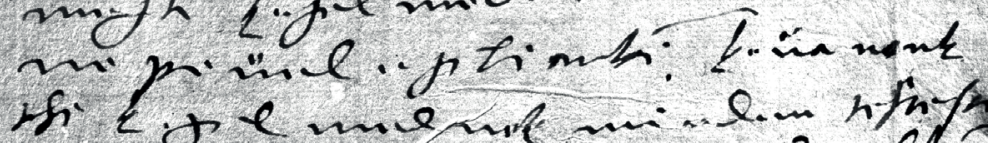

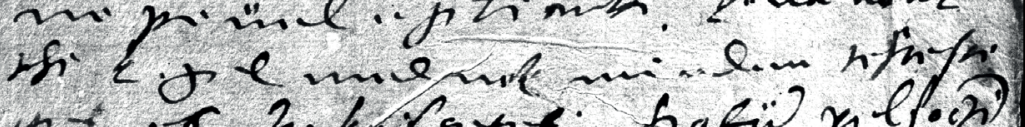

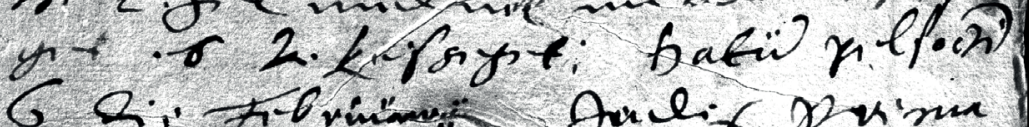

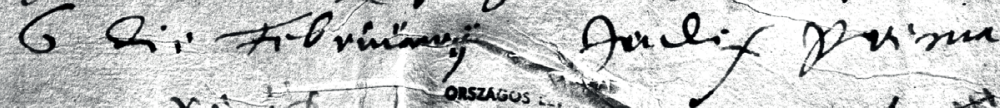
fos. $1575106 r-Y_{0}{ }^{-6}$ Eselein $1+x$

60 


\section{I.9.}

Pelsőc, 1575. II. 6. Pelsöci jobbágyok levele.

Kẅzönetünköt es magünk aiaÿanlasat Irÿük mint tiztelendẅ Vrünknak. Im ertiük hogh the kegielmed azt Irÿa hogh mi mind ${ }^{1}$ meg Irÿük the kegielmednek mint üolt. mi kegielmednek mind zorül zora megh nem Ir hattiük. hane az ket Jamborok zaüabol es bi zadalmas emberek zaüabül ertettük, es mi magünkes hallottünk kinnt. Eloszor mikor az Rüber Vram leüelet fel üittek neki tüd-ni illik czetneki Jonosnak ezt mondüā czetneki Janos. ki külde ez leüelet. az em -ber ki az leüelet fel üitte üolt neki, azt felelte neki. az pelsöczi biro kültü Vra sagodnak, mondüani czetneki Janos. kürüa az annia ez fosos panazlo bestie kürüa fianak. panazlo fosos bestie lelkek megh lattiak hogh ha ennekem ingien kel zolgalnōis Rüber Vramotis meges enime tezlek. megh lattiatok azt fosos bestie lelkek, bozzümoth allom megh lattiatok azt $\mathrm{Az}^{2}$ Vristen algia es tarcza megh tarcza megh kegelmedet minden haza nepeüel egetembē. keüanonk the kegelmednek minden tiztesse get es bekesseget: Datü pelsoczē 6 die Febriüary Judex ${ }^{3}$ Prima riüs

\footnotetext{
${ }^{1}$ A szó utolsó betűje javított; az azt követő jel funkciója nem határozható meg.

${ }^{2}$ Itt megváltozik az írás; esetleg egy másik kéz is bekapcsolódott.

${ }^{3} \mathrm{Az} u$ javított betünek látszik.
} 


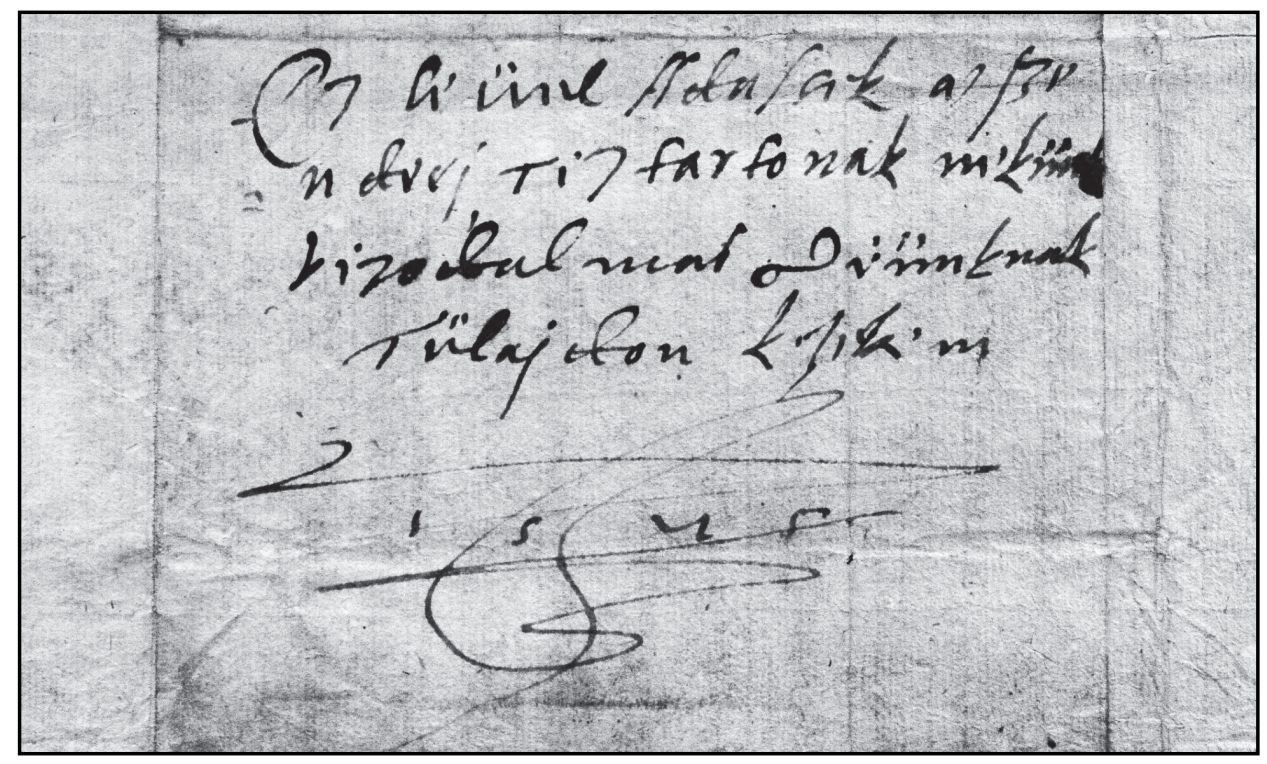


Kivül:

Ez leüel Adassek az sze

-ndrej Tiztartonak nekünk ${ }^{4}$

bizodalmas Vrünknak

Tülajdon kezebem ${ }^{5}$

etc

1575

${ }^{4}$ A szó vége a tintafolt miatt bizonytalanul olvasható.

${ }^{5} \mathrm{~A} b$ helyén először $k$-t kezdhetett a levélíró. 


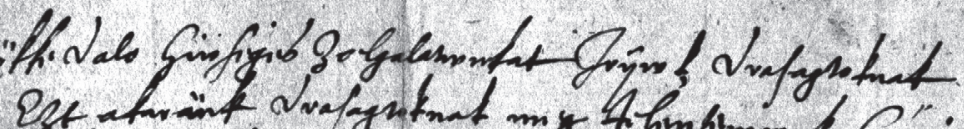

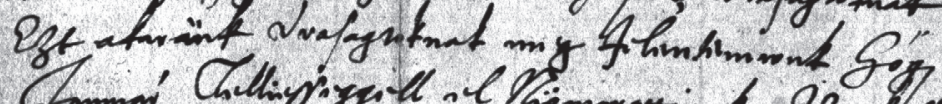

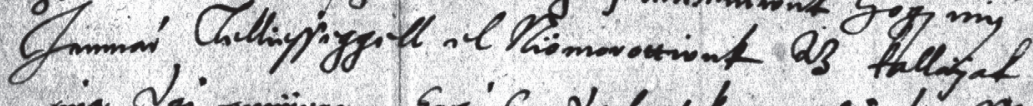

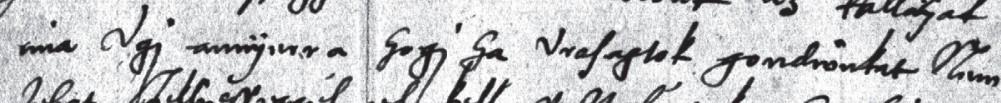

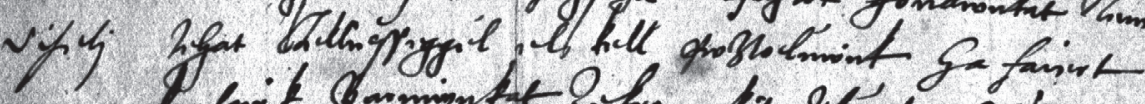

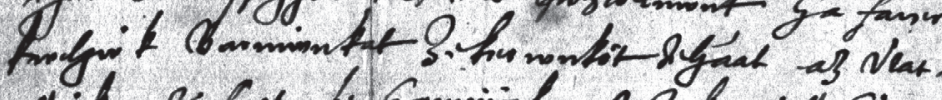

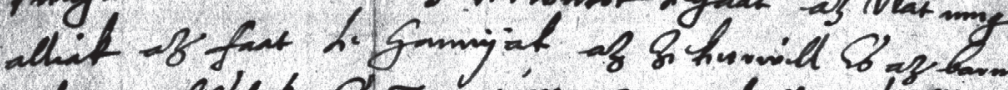

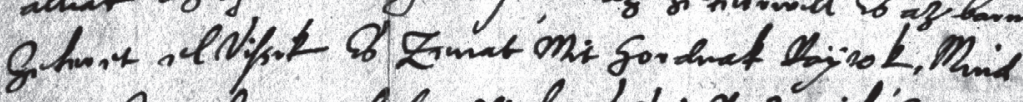

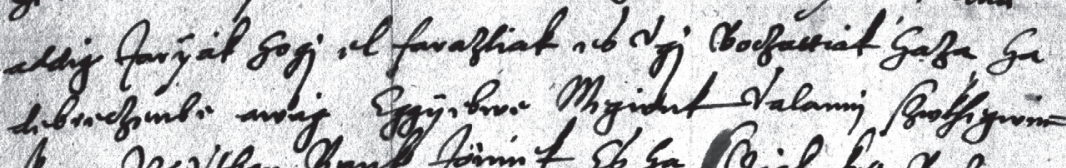

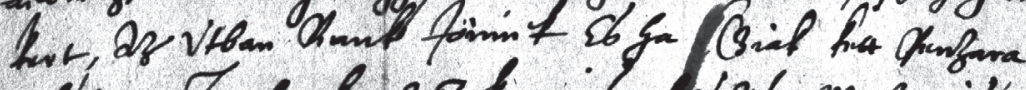

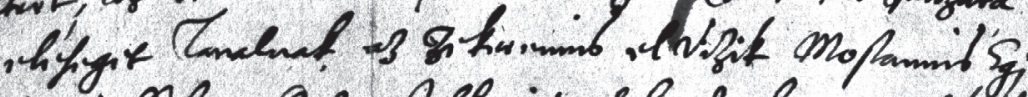

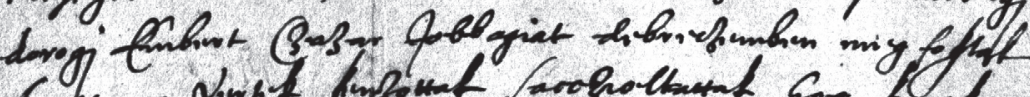

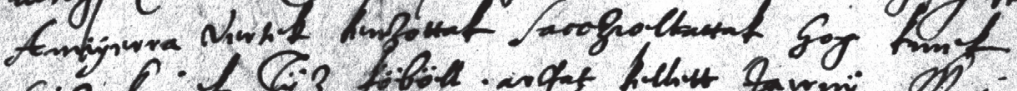

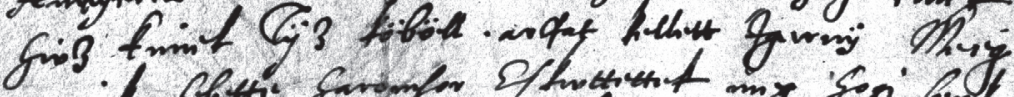

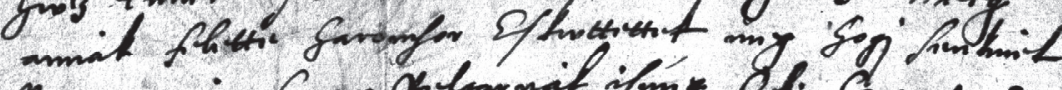

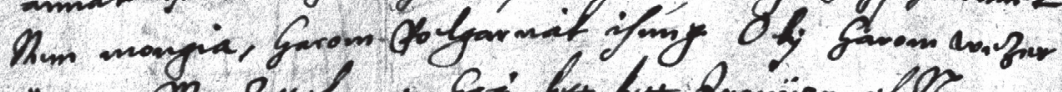

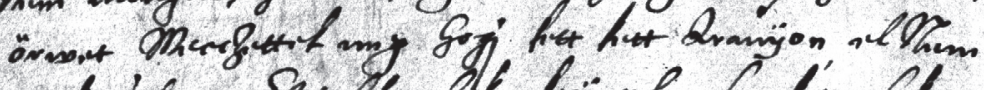

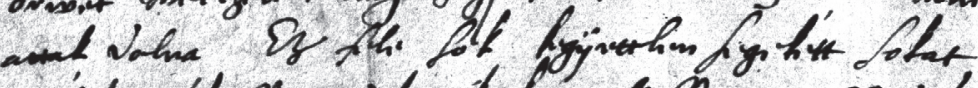

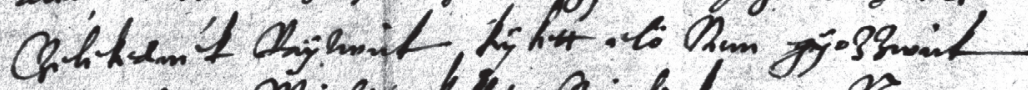

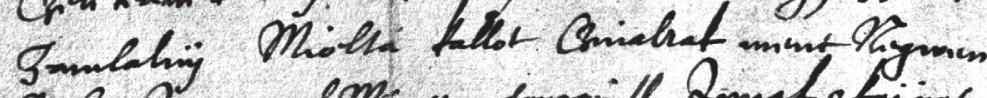

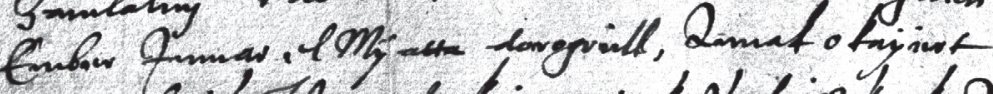

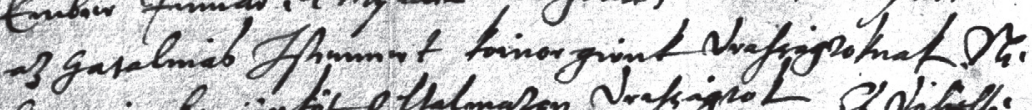

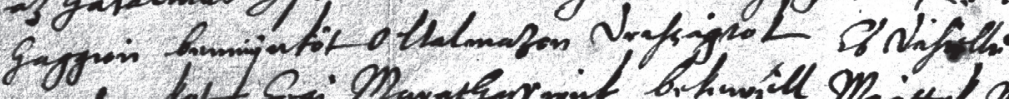

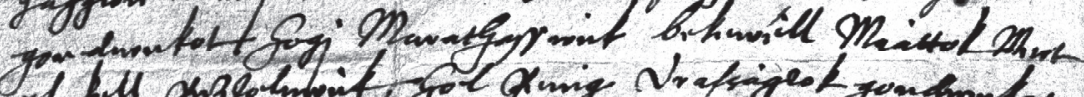

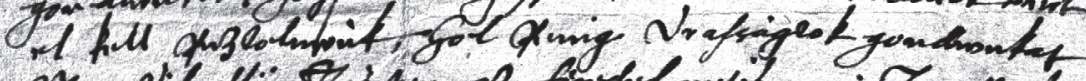

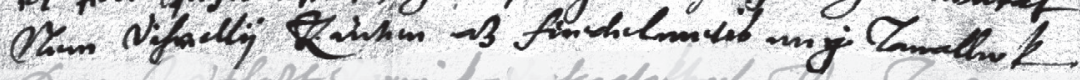


I.10.

Dorog, 1575. X. 16. Dorogi jobbágyok levele.

Erökke valo hwंseges zolgalatwnkat Irÿwk vrasagtoknak, Ezt akarank ${ }^{1}$ vrasagtoknak meg Jelentemwnk hogj mÿ Immär ${ }^{2}$ Telliesseggell el Niomorottwink Az kallaÿak mia vgj annÿerra hogj ha vrasagtok, gondwinkat Nem viselj $^{3}$ tehat Telliesseggel el kell pwztolnwink, ha faiert kwlgwik Barmẃnkat Zekerwnköt tehaat az Vtat meg alliak az faat le hannÿak, az zekerrwill Es az barmot zekeret el vissik Es Zenat Mit hordnak Raÿtok, ${ }^{4}$ Mind addig Jarÿäk hogj el faraztiak es vgj Boczattiak haza, ha debreczenbe awảg Eggÿebwe Megw்nk valamj szwksegw்mkert, ${ }^{5}$ Az Vtban Rank Jönnek Es ha Cziak ${ }^{6}$ kett penzara, eleseget Tanalnak, az Zekerennis el vizik Mostannis Egj dorogj Embert Czazar Jobbagiat debreczemben meg fogtak ${ }^{7}$ Annÿerra Vertek kenzottak sacczoltattak, hog kinek hw்z kinek Tÿz köböll arpat kellett Igernÿ Meeg annảk felette haromsor Eskwttettek, meg hogj senkinek Nem mongia, harom polgarnảk ismeg Olÿ harom wezer örwet Mecczettek meg hogj kett kett Aranÿon, el Nem attak, volna, Ez fele sok kegÿettlensegeket sokat Czelekednek Raÿtwink kÿkett elö nem gÿozzw்nk zamlalnÿ Miolta kallot Czinaltak ment Negwen Ember Immar el Mÿatta dorogrüll, Annak okaÿert az hatalmȧs Istennert koinorgw்nk Vrassảgtoknak, $\mathrm{Ne}$ haggion bennÿnköt ${ }^{8}$ oltalmazon Vrassägtok, Es Viselle gondwnkot hogj Marathasswink bekewell Miattok ${ }^{9}$ Mert el kell puztolnwink, hol penig Vrassảgtok gondwnkat Nem vissellÿ ${ }^{10}$ Zinten $^{11}$ az feiedelmetis meg Tanallwk

\footnotetext{
${ }^{1}$ Az utolsó szótagon $\ddot{w}$-ből való javítás nyoma látszik.

${ }^{2}$ Az utolsó betü fölötti vonást a levélíró pontnak szánhatta az a fölé (1. a levél egyéb helyeit).

${ }^{3}$ A szó - esetleg más kéztől származó - lapszéli beszúrás.

${ }^{4}$ A levélíró talán megduplázta a tagolójelet.

${ }^{5}$ L. az előző lábjegyzetet.

${ }^{6} \mathrm{~A} C$ elött törölt betü nyoma.

${ }^{7}$ A $g$ k-ból javított betü.

${ }^{8} \mathrm{Az} \ddot{y}$ talán megkezdett $\ddot{w}$-ből javított betü.

${ }^{9}$ Az $i$ a-ból javított betünek látszik.

${ }^{10}$ A se betükapcsolat javított.

${ }^{11} \mathrm{~A} Z$ javított betü.
} 

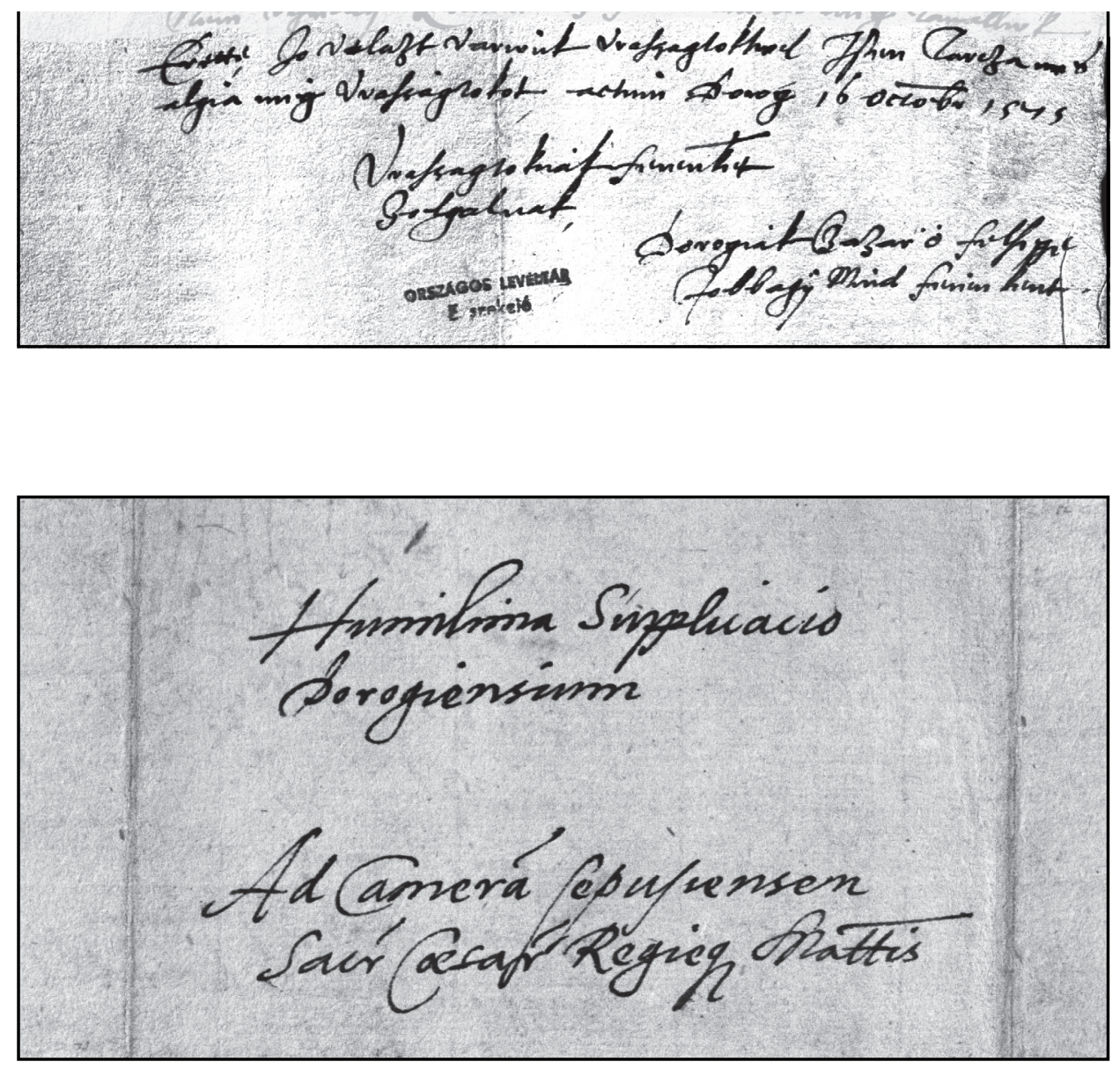
Erette, Jo valazt varwink vrassagtoktwl, Isten Tarcza $<$ me $>$ es algia mèg Vrassagtokot, actum Dorog 16 octobris 1575

Vrassagtoknảk feienkēt

zolgalnak,

Dorogiak Czazar ö felsege

Jobbagÿ mind feienkent,

Kívül más kézzel írva:

Humilima Supplicacio

Dorogiensium

Ad Cameram Sepusiensem

Sacre Caesareae Regieque maiestatis 


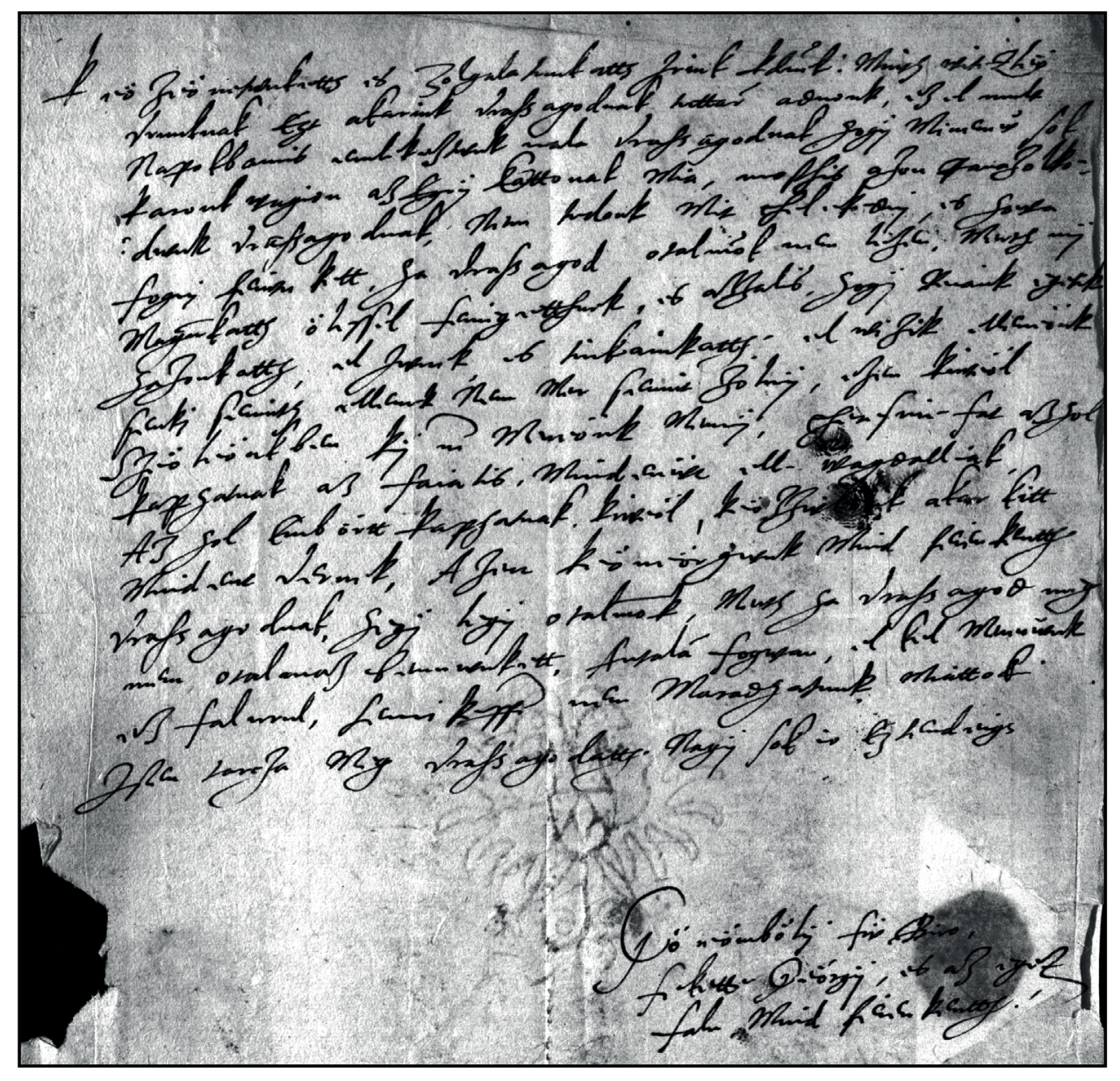




\section{I.11.}

Görömböly, 1578. VI. Fekete György levele.

Keözeönetwnketth es zolgalatunkatth Iriuk kdnek: Minth witezleö Vrunknak Ezt akariuk Vrassagodnak tuttar adnonk, ez el mult Napokbannis emlekeztwnk uala Vrassagodnak hogÿ Minemẅ sok karonk wagion az Egrÿ Kattonak Mia, mosthis azon panazolko-dwnk Vrassagodnak, ${ }^{1}$ Nem tvdonk Mit chelekednj, es howa fognj feiwnkett, ha Vrassagod otalmok nem lezen. Merth mÿ Magūkatth ölessel feniegetthnek, es azzalis, hogÿ Reank egetik hazonkatth, el Jwnek, es tiukainkatth el wizik elleneönk senkj semmit ellenek Nem Mer semmit zolnÿ, ezen kiweöl Szeöleönkben kÿ ne Mereönk Mennÿ, cheresnie fat azhol kaphatnak az faiatis, Mindenẅt ell wagdalliak, Az hol Embörtt kaphatnak kiweöl, keözzய̈leönk ${ }^{2}$ akar kitt Mindent Vernek, Azert keöneörgwnk Mind feienkentth Vrassagodnak, hegÿ legÿ otalmok, Merth ha Vrassagod meg nem otalmaz bennwnkett, Antalā fogwan, el kel Mennẅnk ez falurul, semi keppe nem Maradhatunk Miattok.

Isten tarcza Meg Vrassagodatth. Nagÿ sok io Eztendeigh

Göreömbölÿ fü Biro, fekette Geörgÿ, es az egez falu, Mind feienkentth.

${ }^{1}$ Az első $a$ talán más betünek indult.

${ }^{2}$ A szóra (ahogyan az előző sor fölé is) ujjlenyomat került. 


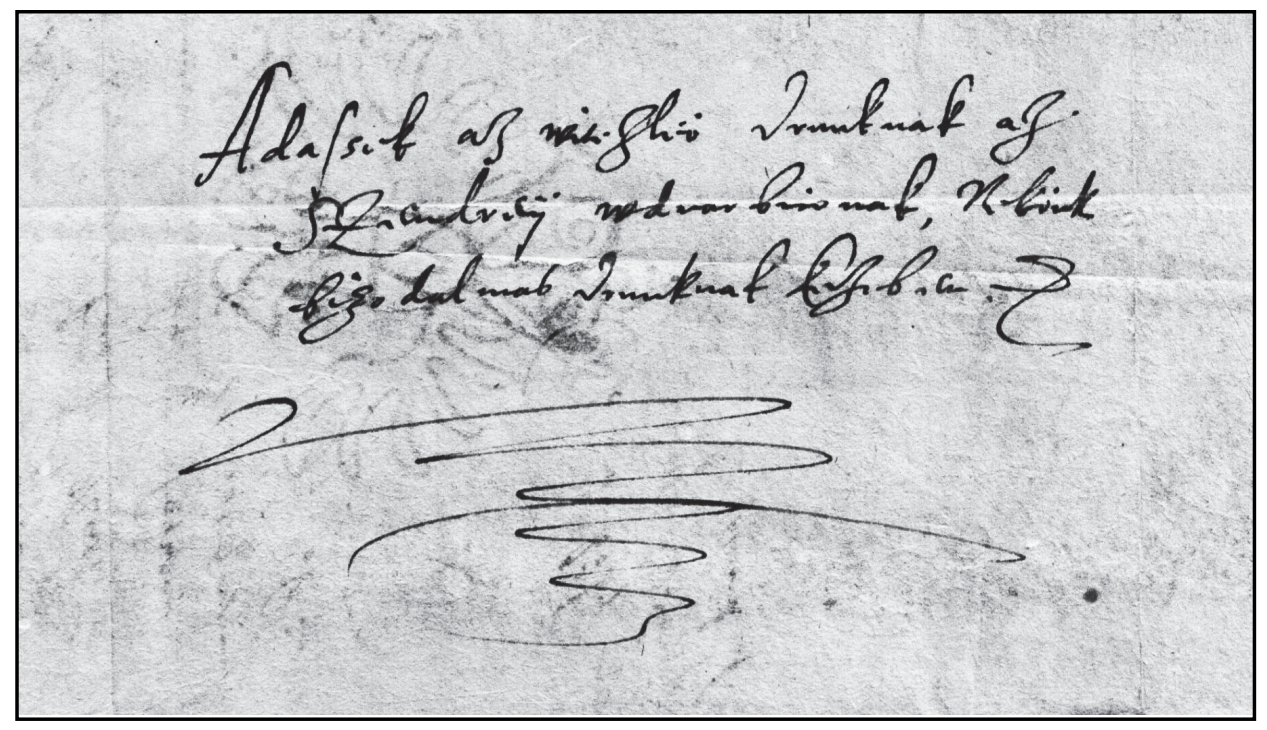


Kivül:

Adassek az witezleö Vrunknak az Szendreÿ wduarbironak, Nekönk bizodalmas Vrunknak Kezeben etc etc 
E 254 - 1579. júl. No. 22.

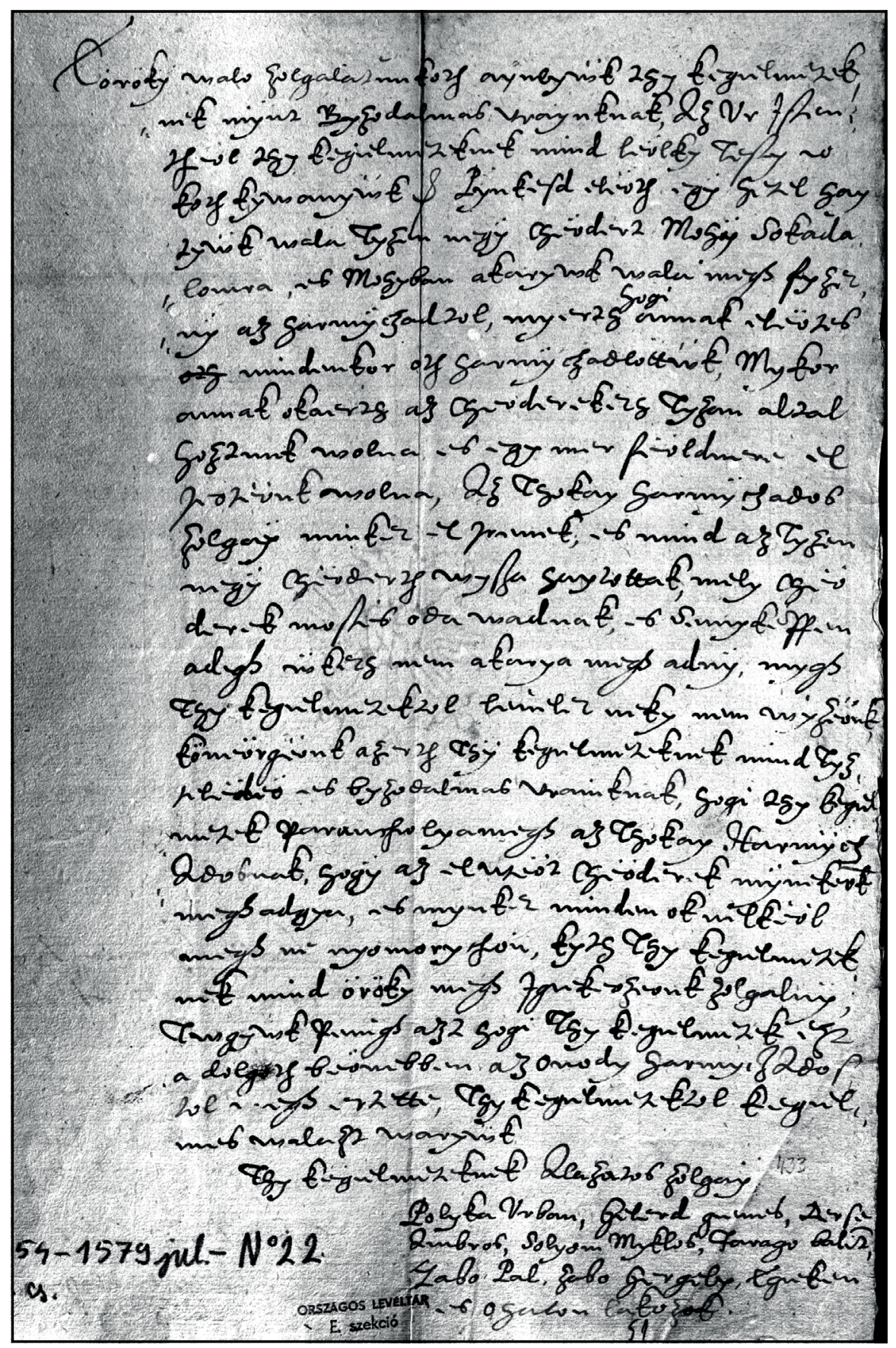

72 


\section{I.12.}

Etyek, 1579. VII. 17. Polyka Orbán, Gellért Dienes, Derse Ambrus, Sólyom Miklós, Faragó Bálint, Szabó Pál, Szabó Gergely levele.

Eörökÿ walo zolgalatŭnkoth ayanlyẅ ${ }^{1}$ thy kegielmetek -nek mÿnt Byzodalmas vraÿnknak, Az Vr Istentheol thy kegielmeteknek mind leölky Testy io koth kywanyẅk etc Pÿnkesd eleöth egy hetel hay tyẅk wala Tyzen negÿ Cheödert Mohÿ² Sokada -lomra, es Mohyban akarywk wala megh fyzet-nÿ az harmÿczadtol, myerth hogi ${ }^{3}$ annak eleötes $<$ oth $>$ mindenkor oth harmÿczadlottẅk, Mykor annak okaerth az Cheodereketh Tyzan altal hoztunk wolna, es egy mer feöldnere el Jeoteönk wolna, Az Thokay harmÿczados zolgaÿ minket el Irenek, es mind az Tyzen negÿ Cheöderth wysza haytottak, mely Cheö derek mostis oda wadnak, es Semykeppen adegh ẅketh nem akarya megh adnÿ, mygh Thy kegielmetektol leŭelet neky nem wÿzeönk, köneörgeönk azerth Thÿ kegielmeteknek mind Tyzteledeö ${ }^{4}$ es byzodalmas vrainknak, hogi thy kegel -metek parancholyamegh az Thokay Harmÿcz -adosnak, hogÿ az elwteöt Cheöderek mÿnekeōk megh adgya, es mynket minden ok nelkeöl megh ne nyomorychon, kyth Thy kegielmeteknek mind öröky megh Igiekeozeonk zolgalnÿ, Twgywk penigh azt hogi Thy kegielmetek ezt a dolgoth beöwebben az onody harmyczados tol megh ertette, Thy kegielmetektol kegielmes walazt waryẅk

Thy kegielmeteknek Alazatos zolgaÿ Polyka Vrban, Gelerd gienes, Derse Ambros, Solyom Myklos, Farago balit, Zabo Pal, Zabo Gergely, Egieken es Ohaton lakozok.

\footnotetext{
${ }^{1}$ A második $a$ utólagos beszúrás a sor fölé.

${ }^{2} \mathrm{Az} \ddot{y}$ más betünek indult.

${ }^{3} \mathrm{~A}$ szó interlineáris betoldás.

${ }^{4} \mathrm{Az}$ utolsó szótagon javítás nyomai látszanak.
} 


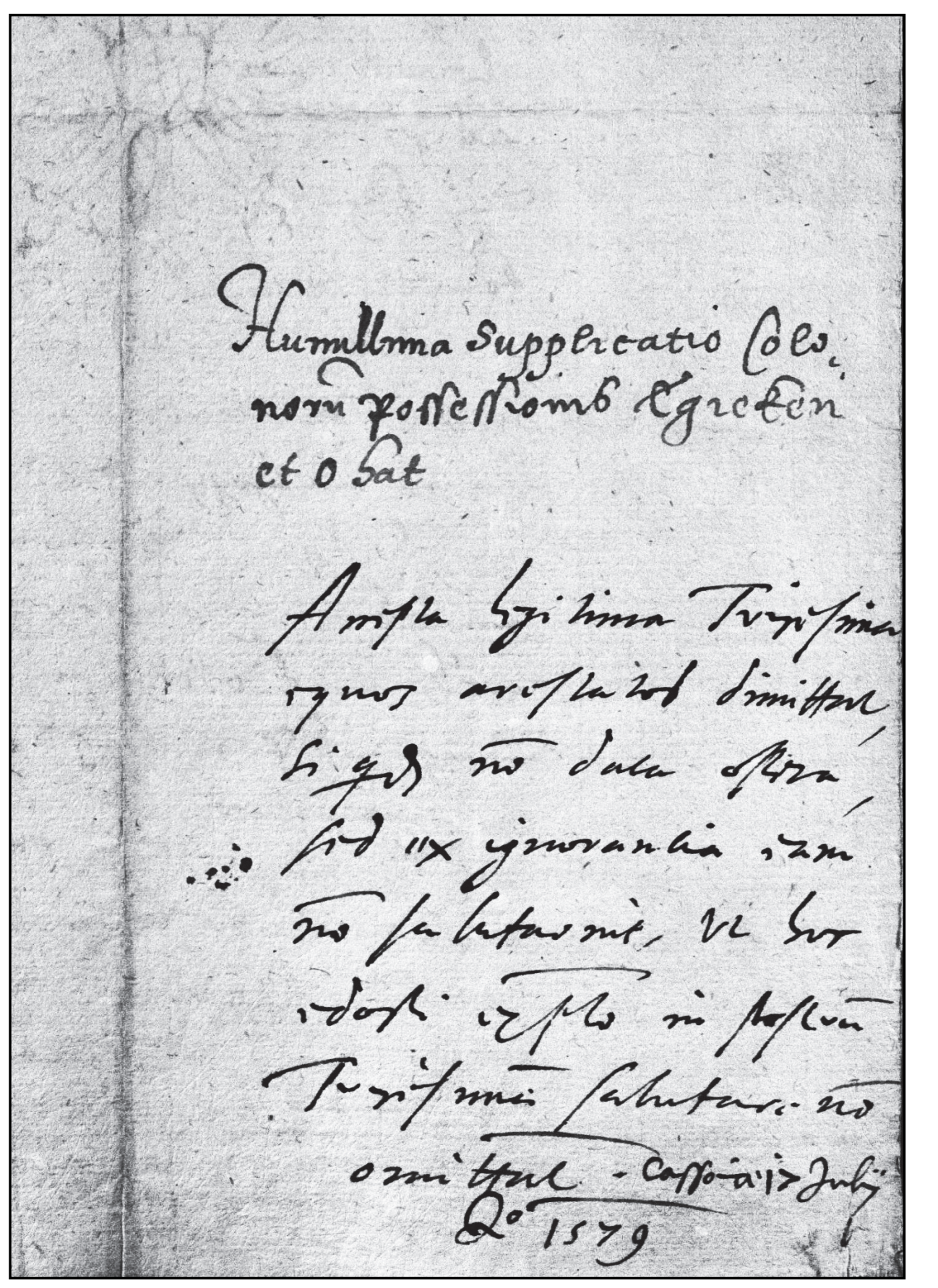

74 
Kívül:

Humillima Supplicatio Colonorum possessionis Egieken et o hat

Más kézzel irva:

Arrepta legitima Tricesima equos arestatos dimittat, siquidem non data opera, sed ex ignorantia eam non salutarunt, vt hoc edocti exemplo in posteum Tricesima $m$ salutare non omittant. ${ }^{5}$ Cassoviae 17 Julÿ Anno 1579

${ }^{5}$ A következő szavakban megváltozik az íráskép; feltehetőleg a datálásba egy másik kéz is bekapcsolódott. 
E 254 - 1580. szept. No. 1.

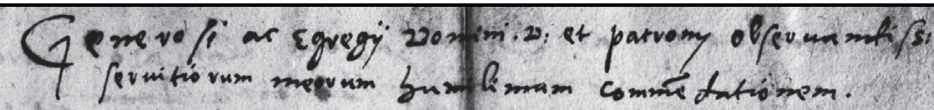

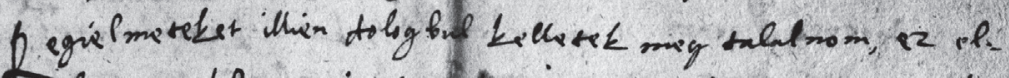
mitt mpokban, njj mimt Vigujfim tevtia Angupti, minek

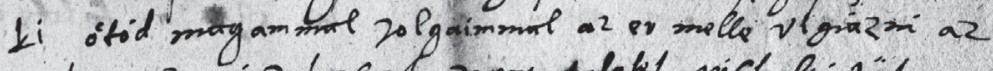

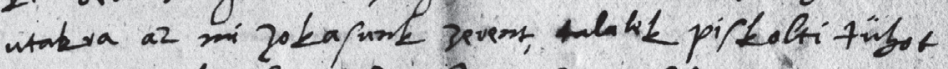

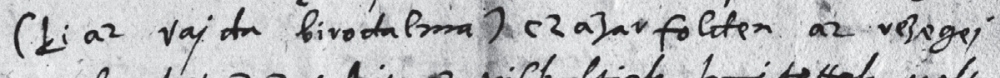
taw lon ket zazat lin a pilsoltiak baj toitak wolk meg a tamazial czazar bivoctul mabul a bur. mincongint on tilpm if titloltak 7 ofy 7 miti: tatrom ef ai tubobat fue mint clajar ifut contivar

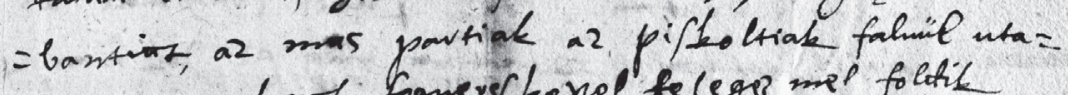
nriam sam damk feguever teezel, feleger mel foltic

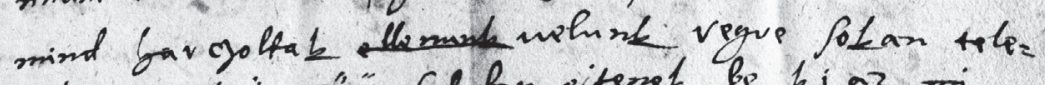
mil es petry ném faluhan sitemel bp $\mathrm{L}_{i}$ az mi

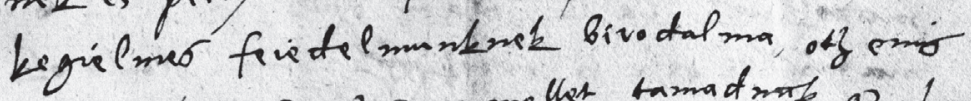
lizman by ar clazave me that tamadme, a2. baran: got folve utettem, ar yavang jora as falube hirk fet

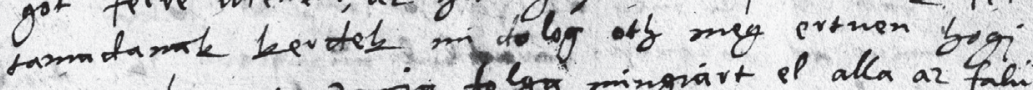

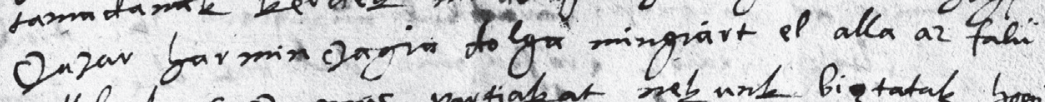
mellohmb is as mas partialeat peknnt bigtatak bapi

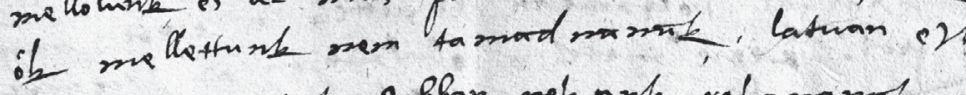
a. mos partiak Jobban menne vobammat a2

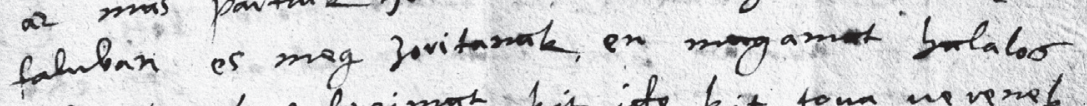
foble effome zolyajmot bit ite kit fom neverk

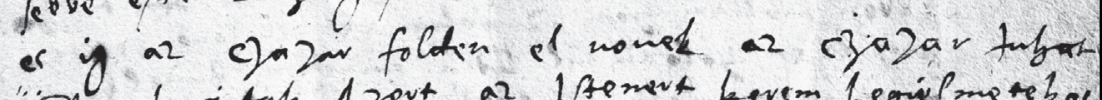

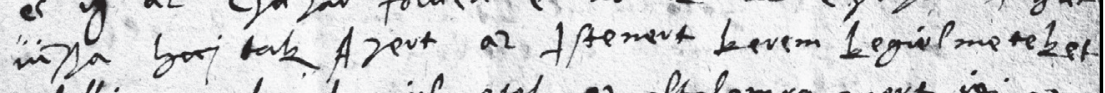

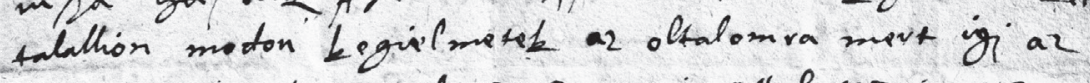

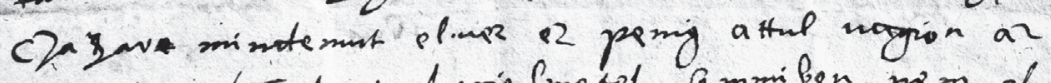

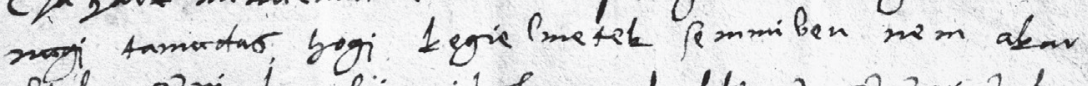

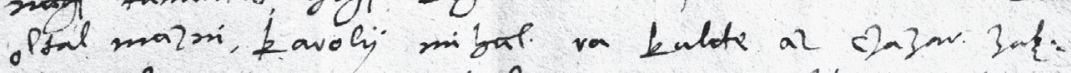
locara, $e^{p}$ nitete al contrabantot para 20 l botam ke = grelmeteknek at pemmiben monkt

76 


\section{I.13.}

Nagykároly, 1580. IX. 1. Rakomazy János levele.

Generosi ac Egregÿ Domini. Domini et patrony obseruandissimi seruitiorum meorum humilimam commendationem.

Kegielmeteket illien dologbul kelletek meg talalnom, ez elmult napokban, ugj mint Vigiesima tertia Augusti, menek ki ôto̊d magammal zolgaimmal az er melle vigiazni az utakra az mi zokasunk zerent, talalek piskolti Jühot (ki az vajda birodalma) czazar folden az rezegej tarlon ket zazat kit az piskoltiak hajtottak uolt meg az tauazzal czazar birodalmabul az harminczagiat en tulem el titkoltak, $<\mathrm{I}>$ oth Inditatam el az Juhokat estue mint czazar $<$ igaz $>$ condra-bantiat, ${ }^{1}$ az mas partiak az piskoltiak faluúl utannam tamadanak fegueres kezzel, fel ${ }^{2}$ egez mel foldik mind harczoltak <ellenunk> uelunk vegre sokan telenek es petrÿ neüü faluban ejtenek be ki az mi kegielmes feiedelmunknek birodalma, oth enis bizuan hogj az czazare mellet tamadnak, az harangot felre utettem, az harang zora az falubeliek fel tamadanak kerdek mi dolog oth meg ertuen hogj Czazar harminczagia dolga mingiart el alla az falü mellolunk, es az mas partiakat nekunk biztatak hogj o̊k mellettunk nem tamadnanak, latuan ezt az mas partiak Jobban nekunk rohananak az faluban es meg zoritanak, en magamat halalos sebbe ejtenek zolgajmat kit ide kit toua uerenek es ig az czazar folden el uouek az czazar Juhat űizza hajtak, Azert az Istenert kerem kegielmeteket talallion modon kegielmetek az oltalomra mert igj az Czazar $<\mathrm{e}>^{3}$ mindenmt eluez ez penig attul uagion az nagj tamadas, hogj kegielmetek semmiben nem akar oltalmazni, karolÿ mihal ra kulde az czazar zazloiara, ${ }^{4}$ el uitete az condrabantot panazolkodam kegielmeteknek $<$ az $>$ semmiben mulek

\footnotetext{
${ }^{1} \mathrm{~A} d$ javított betü.

${ }^{2} \mathrm{Az} f$ javított betü.

${ }^{3}$ A második $z$ javított betü.

${ }^{4}$ A második $z$ l-ből javított betü.
} 


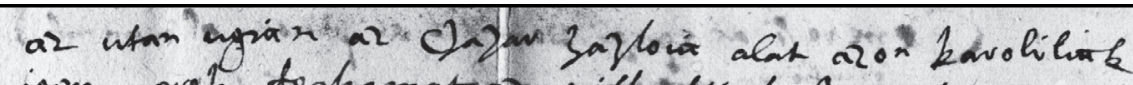

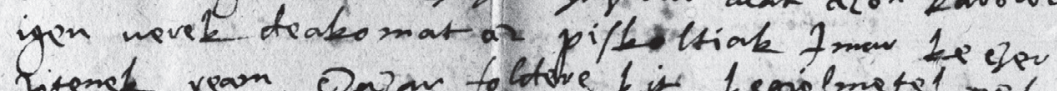

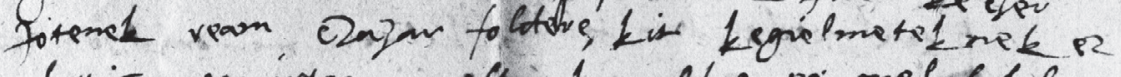

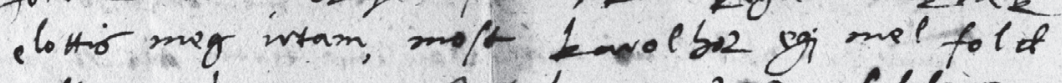

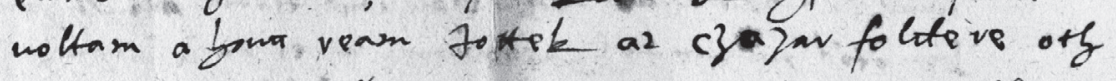
a2 cjajave millet en mager mast bulaloo feblen

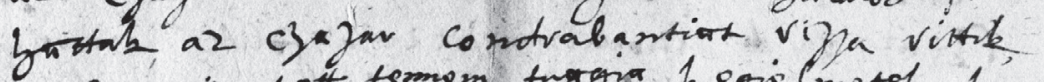
mince mis temom tager 1 egil matel 1 andba

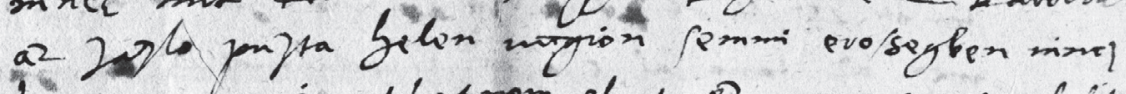

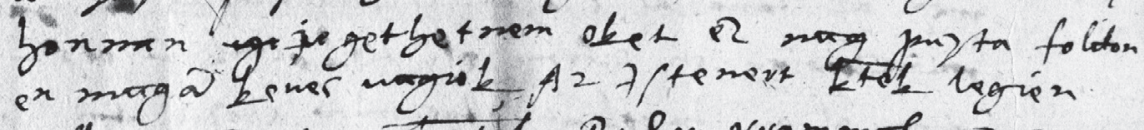
melletem 3ratm kifel Ruber vrammat ar 2ak:

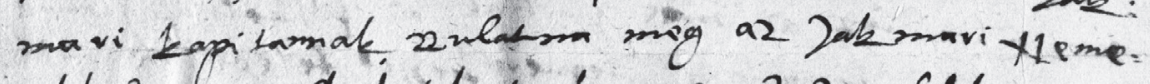

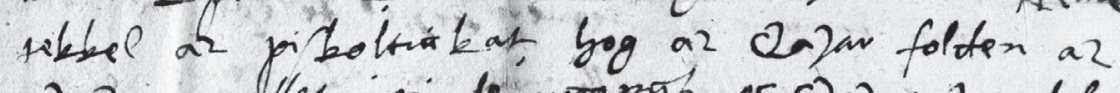
e) Jave mollex igg le worgmak es c)ajar Jome telmax

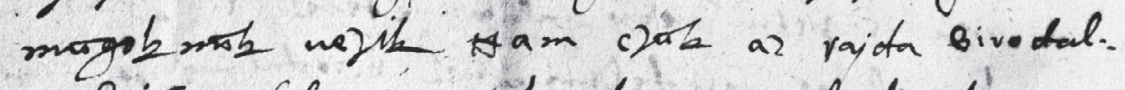

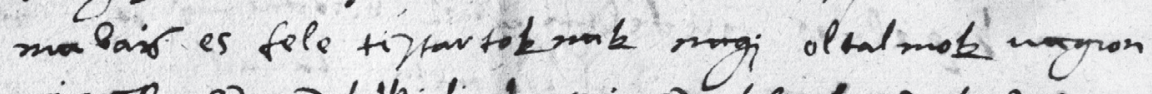

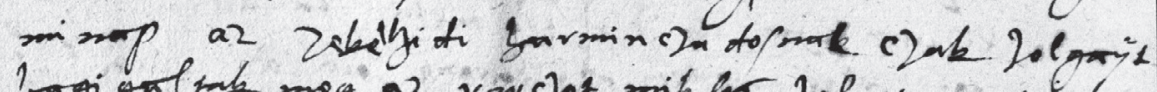

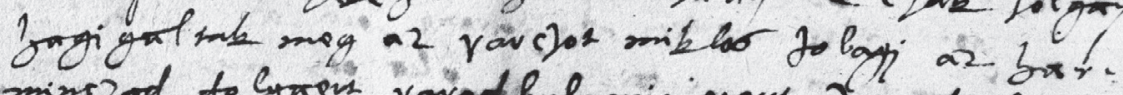
minozed to gyoum vaind bul mingiave 2 ar drabantos

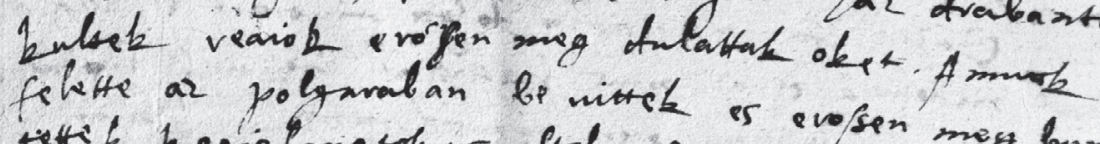

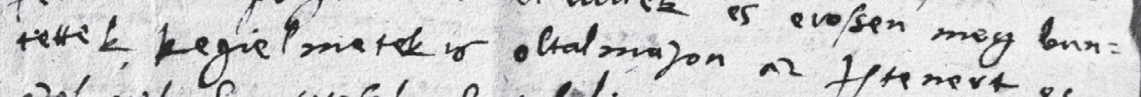

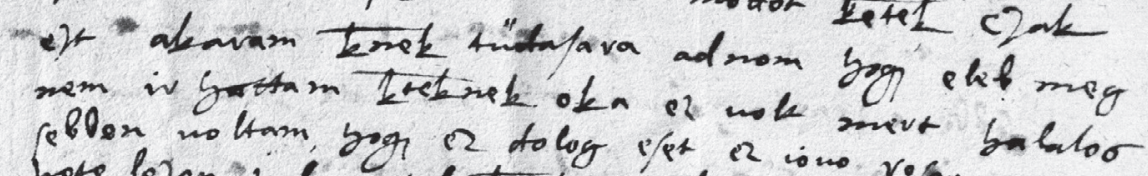

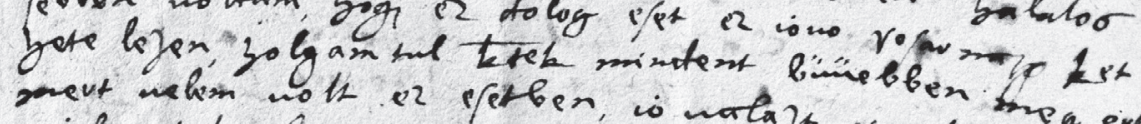

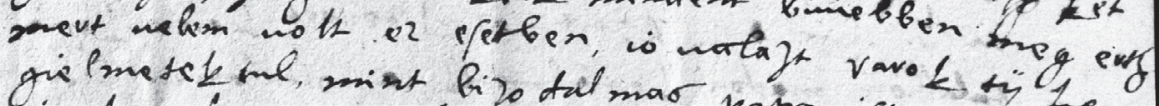

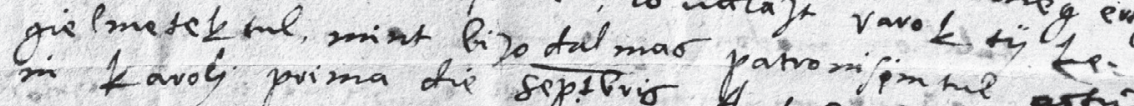

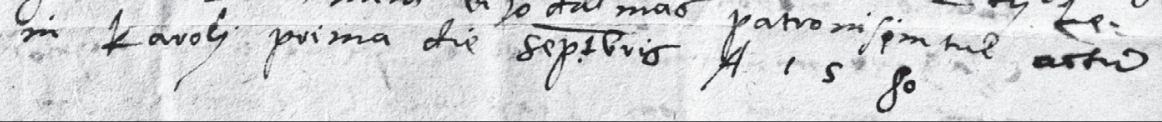


az utan ugian az Czazar zazloia alat azon karoliliak igen uerek deakomat az piskoltiak Imar keczer Jotenek ream, czazar foldere, kit kegielmeteknek ez elottis meg irtam, most karolhoz egj mel fold uoltam a houa ream Jottek az czazar foldere oth az czazare mellet en magamat halalos sebben hattak, az czazar condrabantiat vizza vittik, nincz mit $<$ tett $>$ tennem, tuggia kegielmetek karolb $\bar{a}$ az zazlo puzta helen uagion semmi erossegben nincz honnan $<$ igi $>$ iegethetnem ${ }^{6}$ oket ez nag puzta foldon en maga keues uagiok, Az Istenert ktek legien mellettem, Iratna ketek Ruber vrammal az Zakmari kapitannak, Dulatna meg az Zakmari Nemetekkel az piskoltiakat, hog az czazar folden az czazare mellet igj le uagnak es czazar Jouedelmet magoknak uezik, Nam czak az vajda birodalmabais es fele tiztartoknak nagj oltalmok uagion minap az Zekelhidi harminczadosnak czak zolgaÿt hagigaltak meg az varczot miklos Jobagj az harminczad dolgaert, varadbul mingiart zaz drabantot kultek reaiok erósen ${ }^{7}$ meg dulattak oket, Annak felette az polgaraban be uittek es erossen meg buntettek, kegielmetek is oltalmazon az Istenert es ezeknek buntetesekrul talalion modot ketek czak ezt akaram kneknek tüdasara adnom hogj eleb meg nem irhattam kteknek oka ez uolt mert halalos sebben uoltam, hogj ez dolog eset ez iouo vosarnap ket hete lezen, zolgamtul ktek mindent büüebben meg erth mert uelem uolt ez esetben, io ualazt varok tÿ kegielmetektul, mint bizodalmas patronisomtul ${ }^{8}$ actum in karolj prima die septembris Anno 1580

\footnotetext{
${ }^{5}$ A második $a$ javított betü.

${ }^{6} \mathrm{Az}$ i I-ből javított betü, de a javítás iránya nem egészen bizonyos.

${ }^{7} \mathrm{~A} s$ feltehetően $z$-böl javított betü.

${ }^{8}$ A második $o$ i-ből, esetleg $j$-ből javított betü.
} 

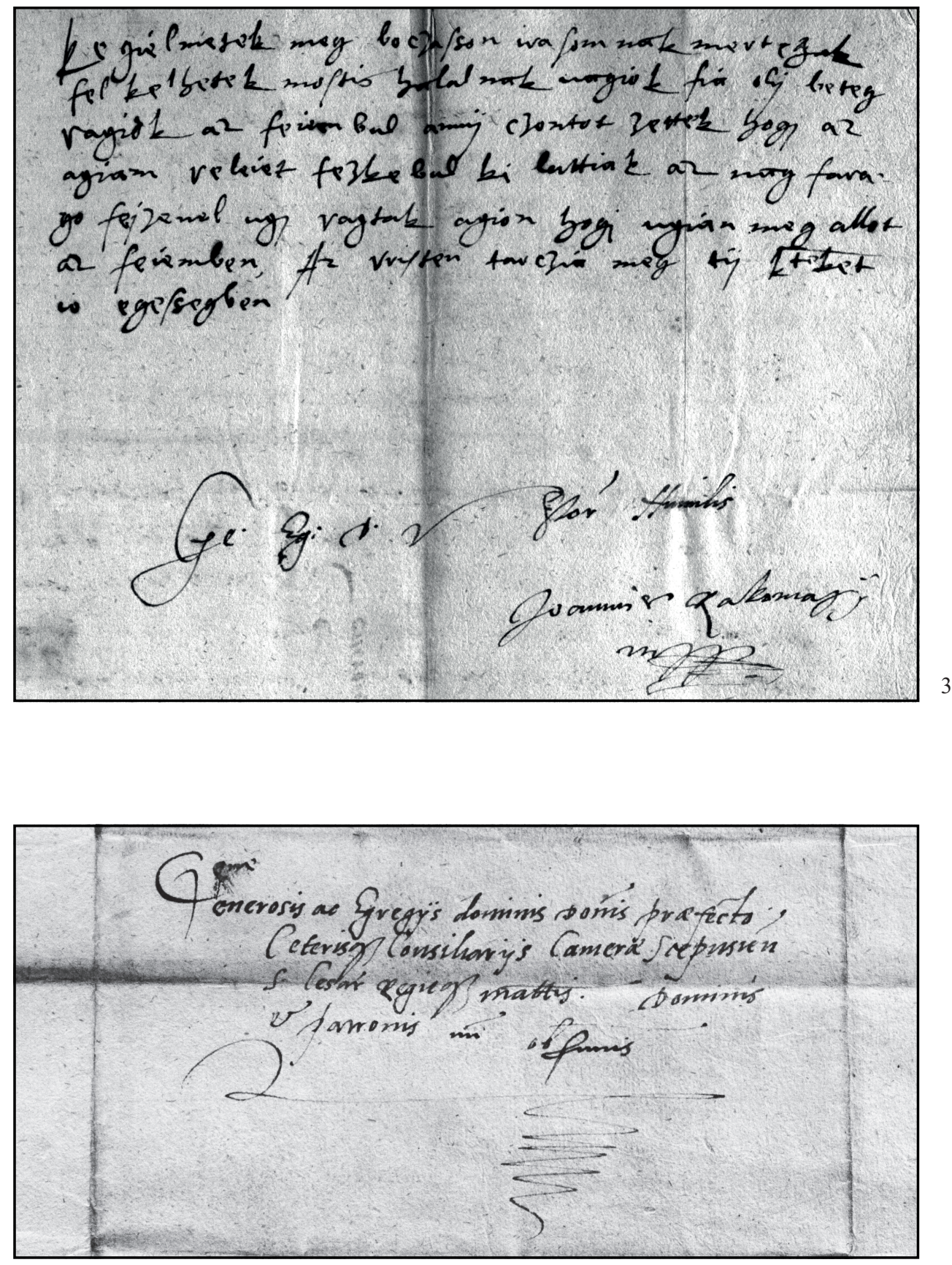
Kegielmetek meg boczasson irasomnak mert czak $^{9}$ fel kelhetek mostis halalnak uagiok fia olÿ beteg vagiok az feiembul ${ }^{10}$ annÿ czontot zettek hogj az agiam veleiet fezkebul ki lattiak az nag farago fejzeuel ugj vagtak agion hogj ugian meg allot az feiemben, Az vristen tarczia meg tÿ kteket io egessegben

Generosae ${ }^{11}$ Egregae Dominationis Vestrae Servitor Humilis

Joannis Rakomazÿ

manu propria

Kívül más kézzel írva:

Generosis $^{12}$ ac Egregÿs dominis Dominis praefecto, Ceterisque Consiliarÿs Camerae Scepusiensis Sacre Cesaree Regieque maiestatis Dominis et patronis mihi observandissimis etc

\footnotetext{
${ }^{9} \mathrm{~A} z$ és a $k$ javítottnak látszik.

${ }^{10} \mathrm{Az} m$ talán $e$-ből javított betü.

${ }^{11}$ Innentől más kéz írása

${ }^{12}$ A nagybetü után három kisbetü eredetileg feljebb van írva.
} 


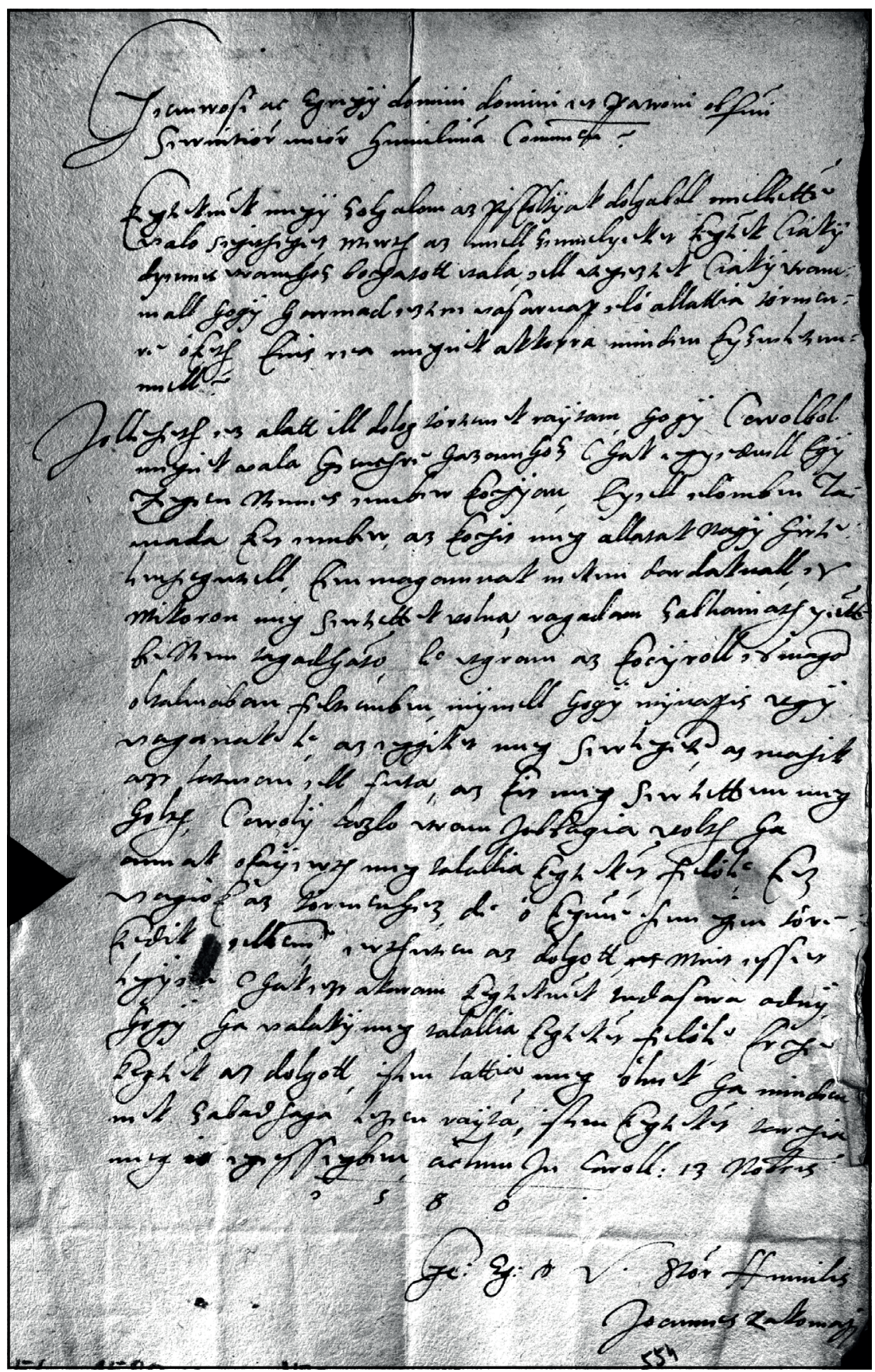




\section{I.14.}

Nagykároly, 1580. XI. 13. Rakomazy János levele.

Generosi ac Egregÿ domini domini et patroni obseruandi seruitiorum meorum humilimam commendationem .

Keğteknek megÿ zolgalom az piskoltÿak dolgaboll melletē valo segitseget, merth az mell zemelyeket keḡtek Ciakÿ dyenes vramhoz ${ }^{1}$ bochatott vala, ell vegeztek Ciakÿ vrammall hogÿ harmad ezten vasarnap eló allattia tóruenre óketh, Enis rea megiek akkorra minden kyzwletemmell .

Jolleheth ez alatt ill dolog tórtenek raÿtam, hogÿ Carolbol megiek vala Genchre hazamhoz Chak egyedwll Egÿ Zegen Nemes ember kochÿan, Eyell elómben Tamada ket ember, az kochit meg allatak nagÿ hirtelensegwell, Een magamnak nekem dardakuall, es Mikoron meg sertettek volna, ragadam zabliamath yettebe Nem tagadhatō, le vgram az kocÿroll es maga oltalmaban feltemben, mÿuell hogÿ mÿnapis vgÿ vaganak le, az eggiket meg sertegete, az masik azt latwan ell futa, az kit meg sertettem meg holth, Carolÿ Lazlo vram Jobbagia volth ha annak okaÿerth meg talallia keḡteket felóle, kez vagiok az tóruenhez, de ó keḡme sem igen tórekedik ellene, erthwen az dolgott, $<$ es $>$ Mint esset legÿen chak ezt akaram kegteknek tudasara adnÿ, hogÿ ha valakÿ meg talallia keğteket felóle, Erche keğtek az dolgott, isten lattia meg ólnek ha minden nek zabadsaga lezen raÿta, isten keḡteket tarchia meg io egessegben, actum In Caroll: 13 Novembris 1580

Generosae Egregiae Dominationis Vestrae servitor Humilis Joannes Rakomazj

${ }^{1} \mathrm{~A} h$ javított betünek látszik. 

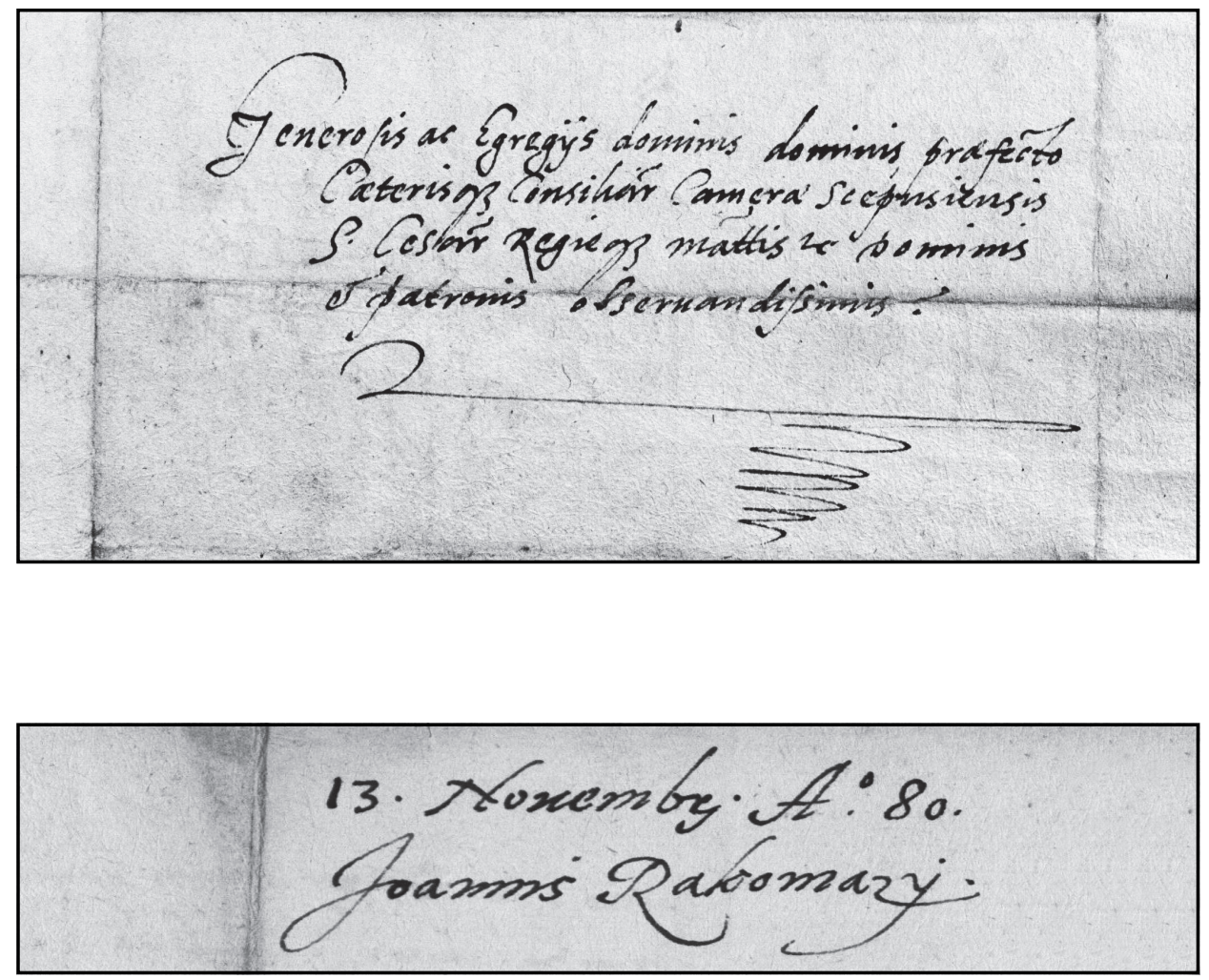
Kivül:

Generosis ac Egregÿs dominis dominis praefecto

Caeterisque Consiliaris Camerae Scepusiensis

Sacre Cesaree Regieque maiestatis et Dominis

et patronis obseruandissimis .

etc

Más kézzel írva:

13. Novembris Anno 80.

Joannis Rakomazÿ. 


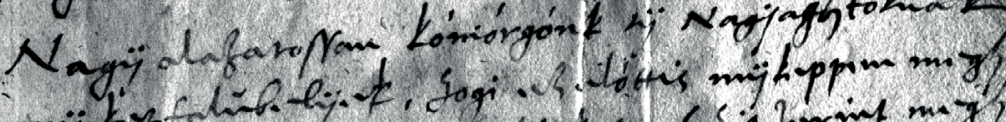

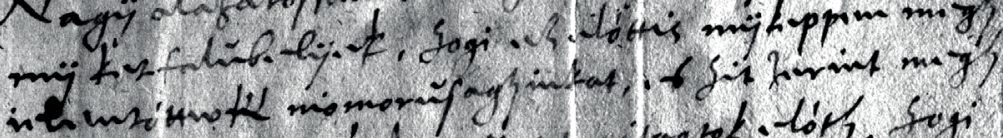

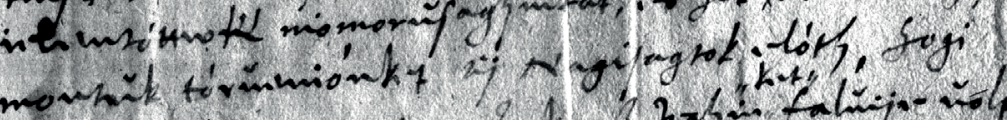

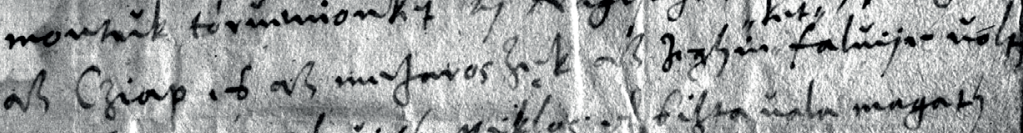

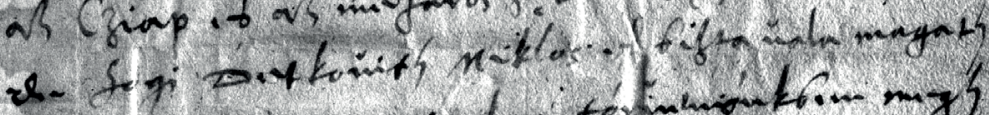
w fogot if vontot minhm tófinhento... my?

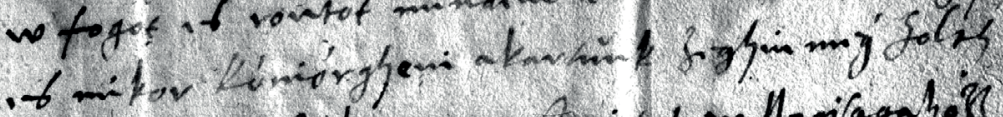

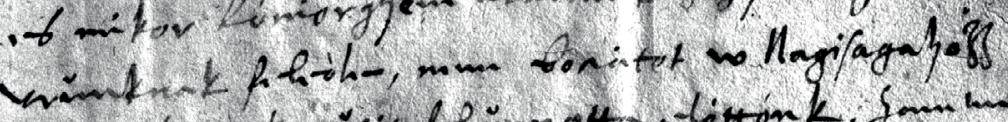

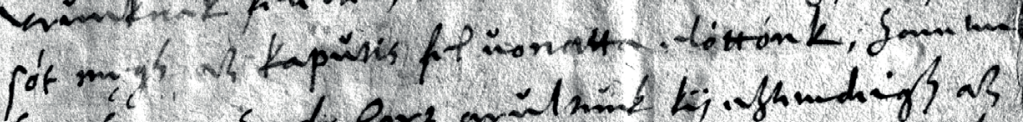

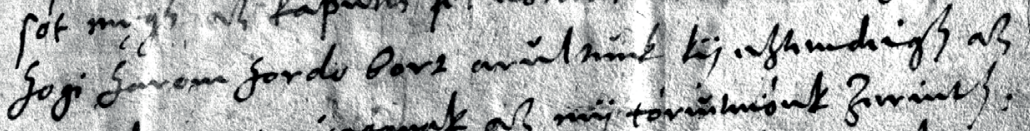

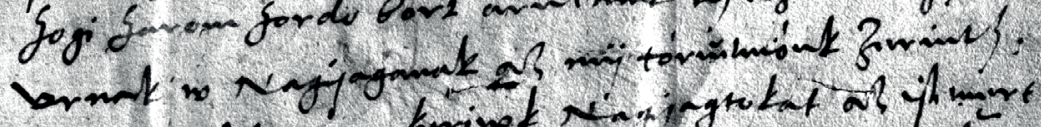

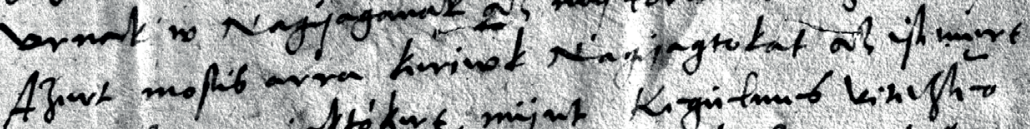

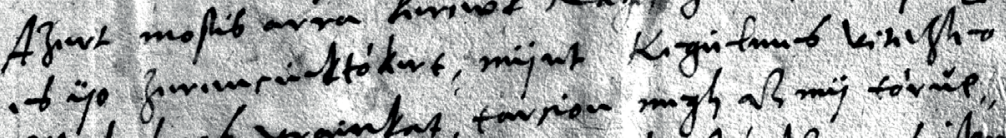

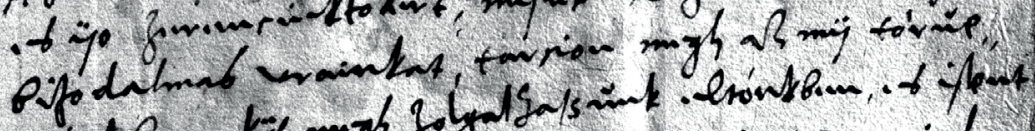

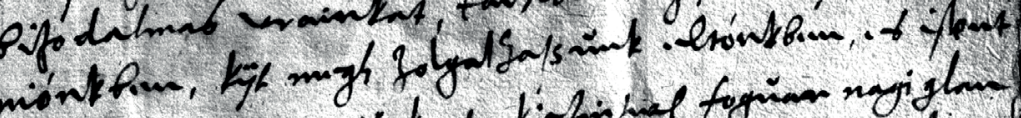

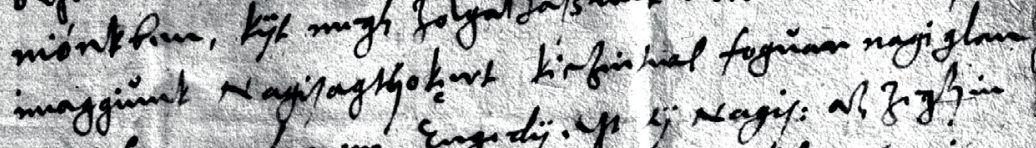

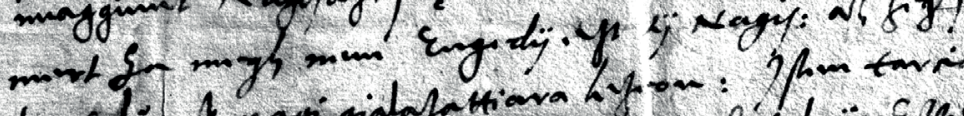

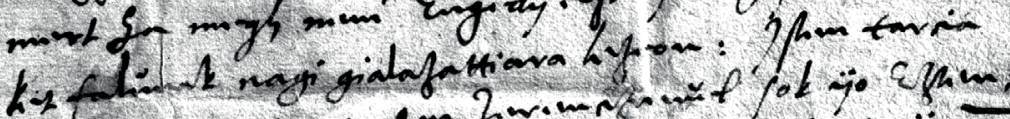

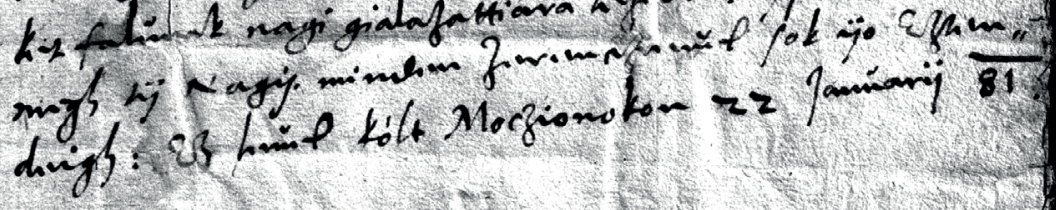

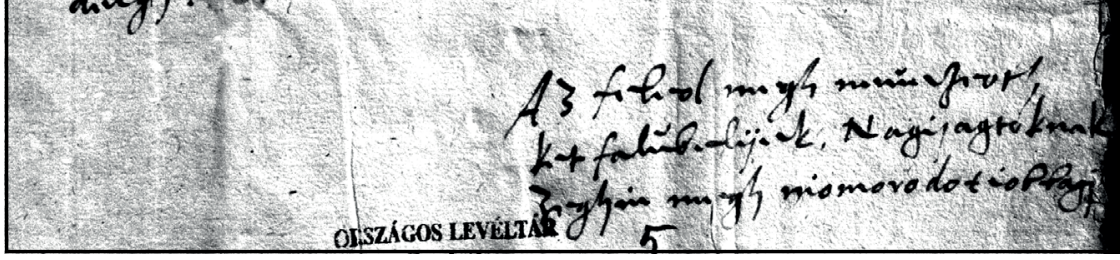




\section{I.15.}

Mocsonok, 1581. I. 22. Mocsonoki és királyi jobbágyok levele.

Mÿ Moczionokÿak es Kiralÿak, nagi alazatossan ${ }^{1}$ ŭalo zolgalatŭnkat aÿanliŭk tÿ Nagisagtoknak, mint Kegielmes ŭitezleo bizodalmas Vrainknak: etc:

Nagÿ alazatossan kóniórgónk tÿ Nagisaghtoknak mÿ ket falŭbelÿek, hogi ezelóttis mÿkeppen megh ielentóttwk ${ }^{2}$ niomorŭsaghinkat, es hit zerint megh montŭk tórŭeniónket tÿ Nagisagtok elóth, hogi az Cziap es az mezaros zęk az zeghin ket ${ }^{3}$ falŭÿe ŭolt, de hogi Detkoŭith Miklos el bizta ŭala magath w fogot es rontot minden tórŭeniónkben megh es mikor kóniórgheni akartŭnk zeghin $\mathrm{meg}^{4}$ holth vrŭnknak feleóle, nem bociatot w Nagisagahozz sót męgh az kapŭtis fel ŭonatta elóttónk, hanem hogi harom hordo bort arŭltŭnk kÿ eztendeigh az vrnak w Nagisaganak az mÿ tórŭeniónk zerinth: Azert mostis arra keriwk Nagisagtokat az istenęrt es ÿo zerenciektókert, mÿnt Kegielmes vitezleo bizodalmas vrainkat, tarcion megh az mÿ tórŭeniónkben, kÿt megh zolgalhassŭnk eltónkben, es istent imaggiŭnk Nagisagthokęrt kiczintwl fogŭan nagiglan mert ha megh nem Engedÿ ezt tÿ Nagis: az zeghin ket falŭnak nagi gialazattiara lezeon: Isten tarcia megh tÿ Nagis. minden zerenczieǔel sok ÿo Eztendeigh: Ez leŭel kólt Moczionokon 22 Janŭarÿ 81.

Az feleol megh neŭezeoth ket falŭbelÿek, Nagisagtoknak zeghin megh niomorodot iobbagj

\footnotetext{
${ }^{1}$ Az $n m$-böl javított betü.

${ }^{2} \mathrm{~A} k n$-böl javított betü.

${ }^{3} \mathrm{~A}$ szó a sor fölötti betoldás.

${ }^{4} \mathrm{~A} g$ fölött talán $h$ betü kezdete látszik.
} 


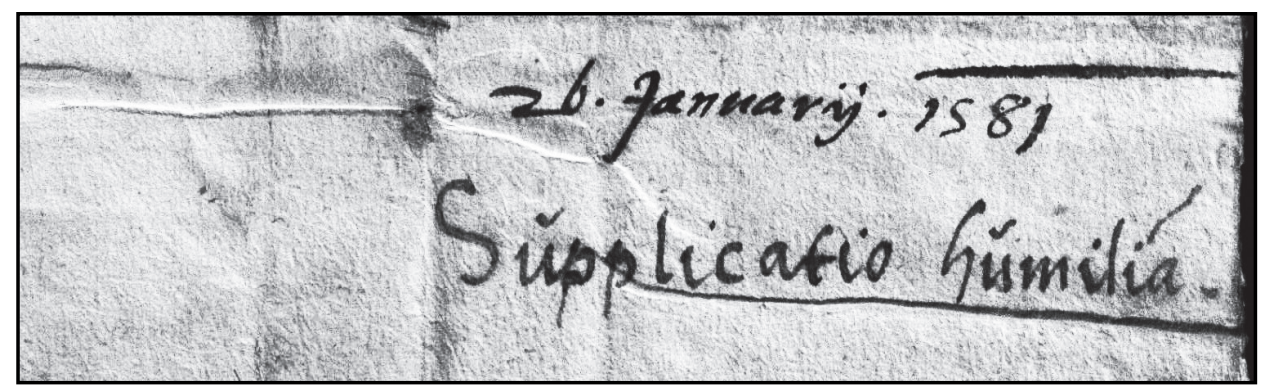


Kívül más kezekkel írva:

26. januarÿ. 1581

Sŭpplicatio hŭmilima. 


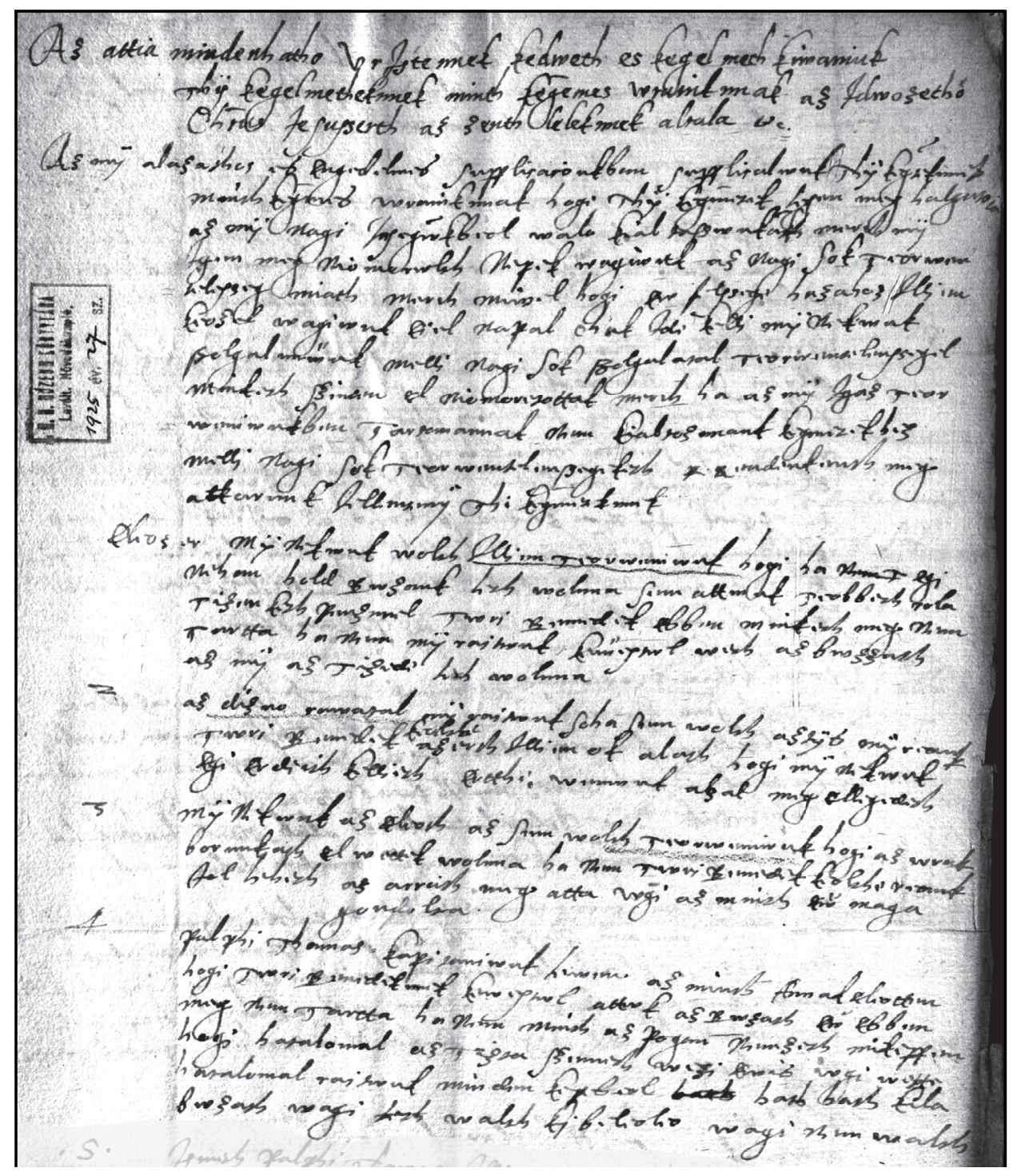




\section{I.16.}

Inota, 1581. X. 23. Inotai jobbágyok levele.

Az attia mindenhatho Vr Istennek kedweth es kegelmeth kiwaniuk thÿ kegelmetheknnek minth kegemes wrainknnak az Idwozetheo ${ }^{1}$ Chrus Iesusserth az zenth leleknnek altala etc.

Az mÿ alazathos es engedelmes supplicacionkban supplicalwnk thÿ kegteknnek minth $^{2}$ keḡmes wrainknnak hogi thÿ keḡmetek legen meg halgatoia az mÿ nagi Insegwwkbeol walo kialtasswnkakh ${ }^{3}$ merth mÿ Igen meg niomorwlth Nepek wagiwnk az nagi sok teorwen -telesseg miath merth miwel hogi ew felssege hazahoz Illien keozel wagiwnk eiel napal chak Ide kelli mÿ nekwnk szolgalnnw"nk melli nagi sok szolgalatal teorwentelenssegel minketh szinten el niomoretottak merth ha az mÿ Igaz teor weniwnkben tartanannak nem kialtoznnank kegmetekhez mellj nagi sok teorwentelenssegeketh $<\mathrm{p}$. $>$ Rendenkenth meg $\mathrm{a}<\mathrm{l}>$ karwnk Jellentenÿ thi kegmeteknnek

Eleozer Mÿ nekwnk wolth Illien teorweniwnk ${ }^{4}$ hogi ha $<$ nem $t>$ egi nehan hold Bwzank leth wolnna sem attwnk teobbeth rola tizen keth penznnel twri Bennedek ebben minketh meg nem tartta ha nem mÿ raitwnk kewestwl weth az bwzzath az mÿ az tizede leth wolnna

2 az dizno rawatal mÿ raitwnk soha sem wolth aztÿs mÿ reank twri Benedek keolthe ${ }^{5}$ azerth Illien ok alath hogi mÿ nekwnk egi erdeith kellieth ertthe wenwnk azal ${ }^{6}$ meg ellegedeth

3 mÿ Nekwnk az eleoth az sem wolth teorweniwnk hogi az wrak borunkath el wettek wolnna ha nem twri Benedek keolthe reank Jol leheth az arrath meg atta wgi az minth ew maga gondolta.

4 palphi thamas kapitaniwnk lewen az minth Annak eleotten hogi twri Benedeknnek kewestwl attwk az Bwzath ew ebben meg nem tartta ha nem minth az pogan nemzeth mikeppen hogi hatalomal az tizta szemeth wezi ewis wgi wette hatalomal raitwnk minden kepebeol $<$ hath $>$ hath hath kila bwzath wagi $<$ hath $>$ walth kj beleoleo wagi nem walth

\footnotetext{
${ }^{1}$ Az második $e$ betoldásként az $o$ fölé került.

${ }^{2} \mathrm{Az} i$ javított betünek látszik.

${ }^{3}$ A harmadik $k$ talán $t$-ből javított betü.

${ }^{4}$ E szavaktól kezdődően a levél néhány helyén grafitceruzás, ill. kék ceruzás jelölések láthatók.

${ }^{5}$ A szó interlineáris betoldás, a $h$-n javítás nyoma látszik.

${ }^{6} \mathrm{~A} z$ l-böl javított betü.
} 


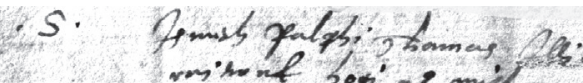

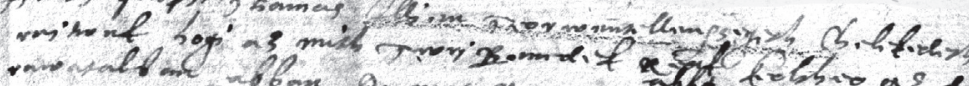

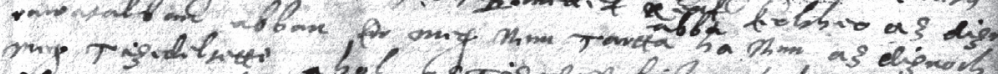

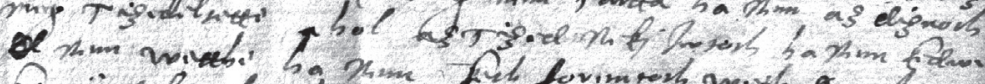

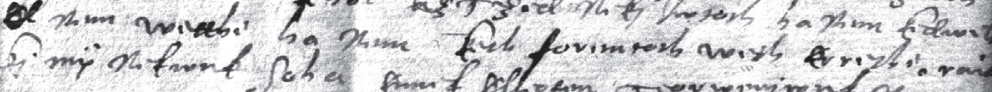

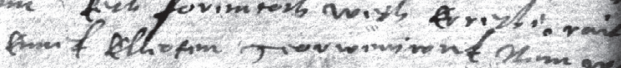
Hines of

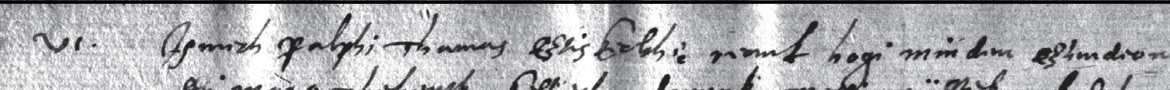

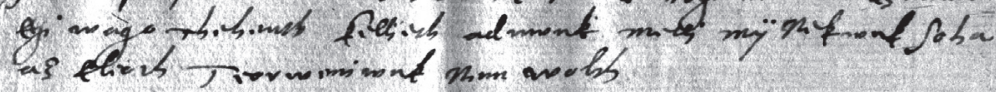

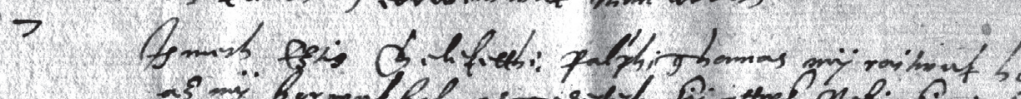

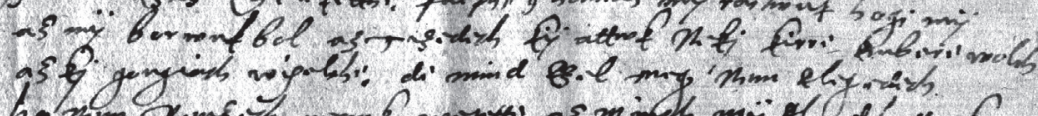

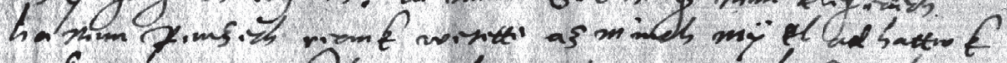

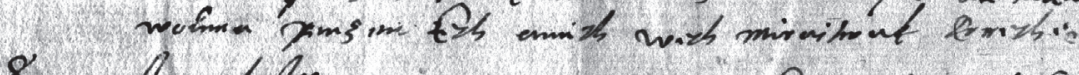

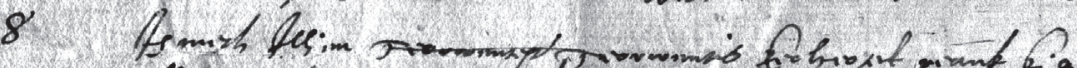

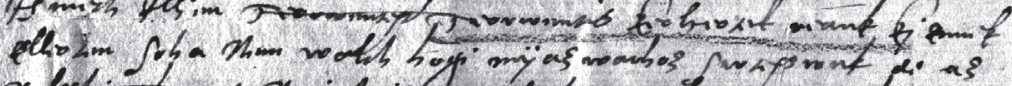

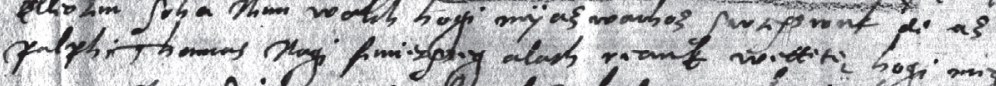

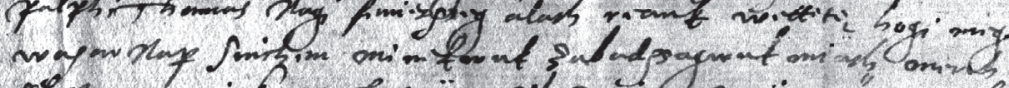

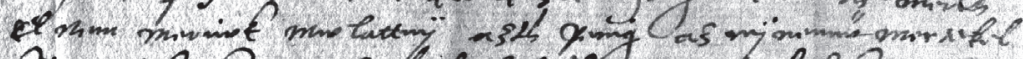

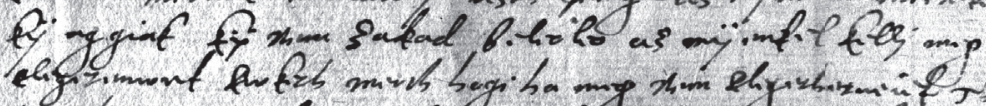

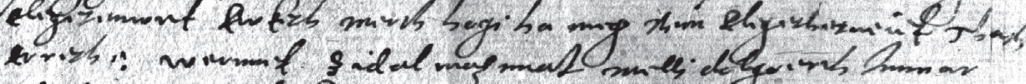

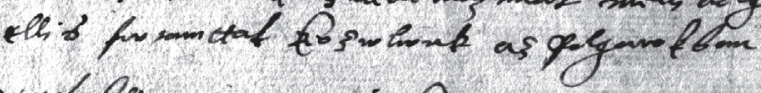

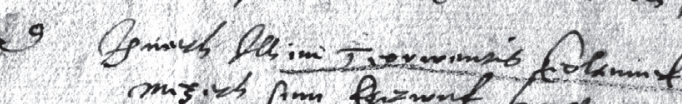

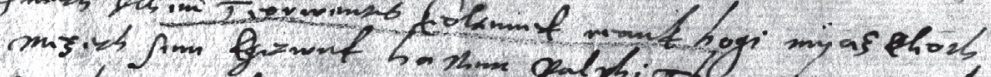

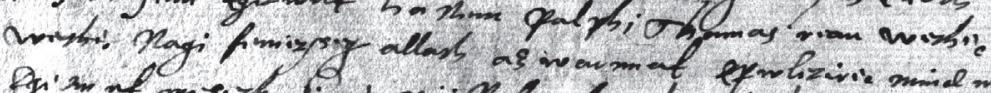

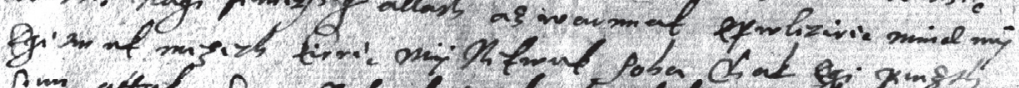

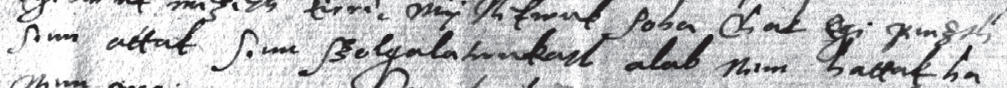

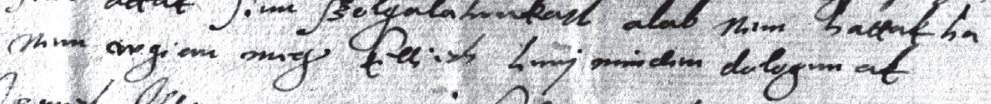

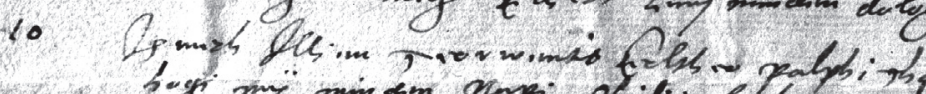

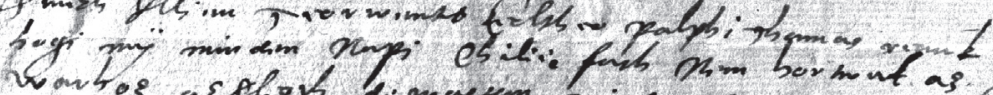

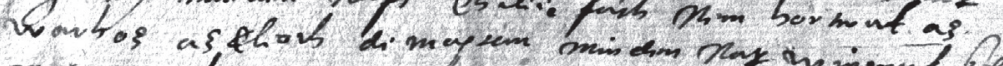

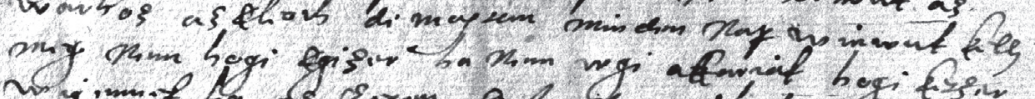

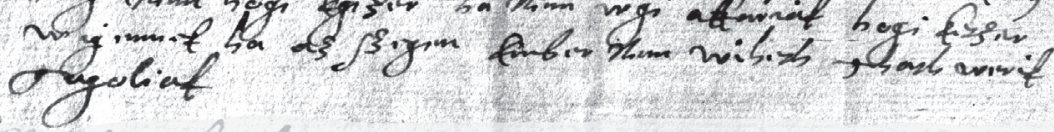


5 Ismeth palphi thamas Illien teorwentellenssegeth chelekedeth raitwnk hogi az mith twri Bennedek Reak keoltheo az dizno rawatalban abban ew meg nem tartta $\mathrm{abba}^{7}$ ha nem az diznoth meg tizedeltette ahol az tized nekj Jwtoth ha nem kedwelth $\mathrm{el}^{8}$ nem wetthe ha nem keth forentoth weth errethe raitw[..] kj mÿ nekwnk soha ennek elleoten teorweniwnk nem wolth,

VI. Ismeth palphi thamas eztis keolthę reank hogi minden eztendeon egi wago thehenth kellieth adnwnk melli mÿ nekwnk soha az eleoth teorweniwnk nem wolth

7 Ismeth eztis cheleketthę palphi ${ }^{9}$ thamas mÿ raitwnk hogi mÿ az mÿ borwnkbol az tizedeth kÿ attwk nekj kirre embere wolth az kj gongiath wiselthę de mind ezel meg nem elegedeth ha nem penzeth reank wetette az minth mÿ el adhattwk wolnna penzen keth ennith weth miraitwnk errethę

8 Ismeth Illien $<$ teorwentes. $>$ teorwentis keolteotek reank kj ennek elleoten soha nem wolth hogi mÿ az warhoz swtesswnk de az palphi thamas nagi fenietsseg alath reank wettetę hogi meg wasar nap sinchen mi nekwnk zabadssagwnk miath merth el nem meriwk mwlattnÿ azth penig az mÿnemw" mertekel kÿ aggiak kÿ nem zakad beleoleo az mÿenkel kellj meg elegetenwnk ewketh merth hogi ha meg nem elegethetnenk ${ }^{10}$ thath errethę wernnek zidalmaznnak melli dolgaerth Immar ellis fwtamttak keozwlwnk az polgarokban

9 Ismeth Illien teorwentis keoltennek reank hogi mÿ az eleoth mezeth sem Egetwnk ha nem palphi thamas rean wethę $<$ wethę> Nagi fenietsseg allath az warnnak epwletirę mind mÿ Egetwnk mezeth kirrę mÿ Nekwnk soha chak egi penzth sem attak sem szolgalatunkath alab nem hattak ha nem wgian meg kellieth lennj minden dolognnak

10 Ismeth Illien teorwentis keoltheo palphi thamas reank hogi mÿ minden napi chilię fath nem hortwnk az warhoz az eleoth de mastan minden nap winwnk kellj meg nem hogi egizer ha nem wgi akkariak hogi ketzer wigennek ha az szegen Ember nem wiheth thath werik tagoliak

\footnotetext{
${ }^{7} \mathrm{~A}$ szó interlineáris betoldás.

${ }^{8}$ A szón javítás nyoma látszik. - A sor végénél elszakadt a papír.

${ }^{9} \mathrm{Az} l$ utáni vonás feltehetően tévesen kezdett $h$ maradványa.

${ }^{10} \mathrm{Az} n$ fölött szándéktalannak tünő vonal van.
} 


\section{in sise erinel

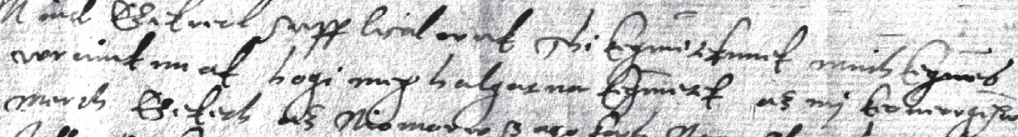

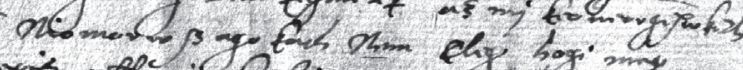

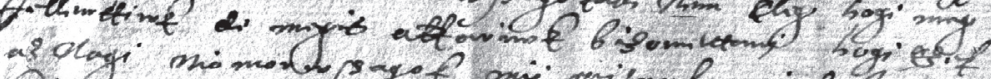

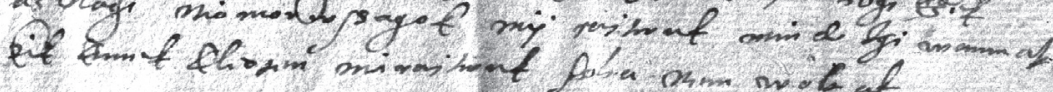

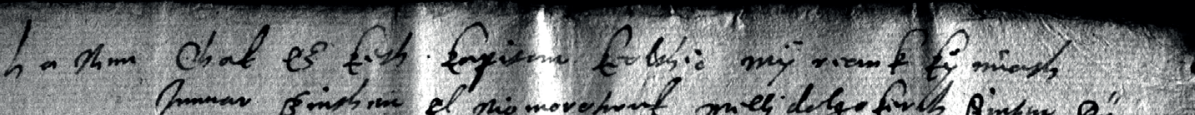

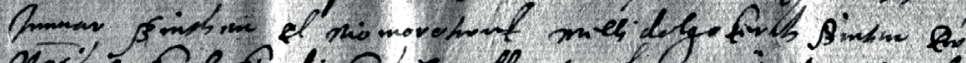

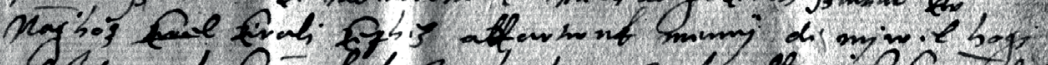

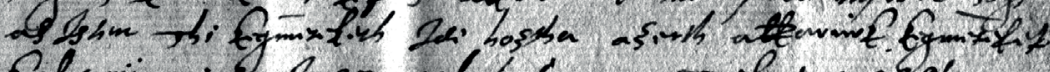

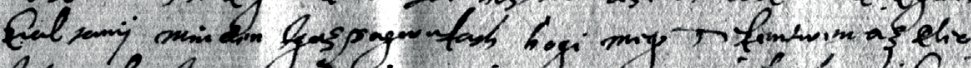

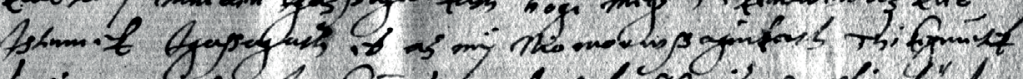

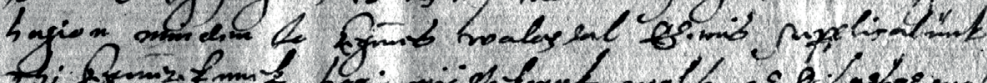

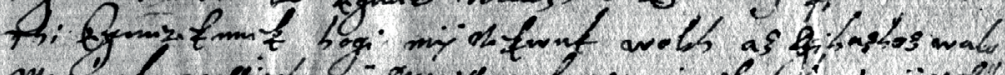

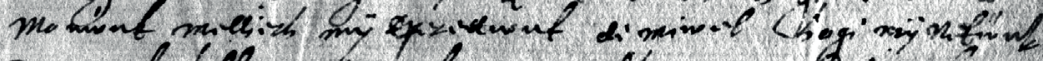

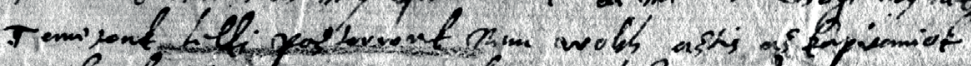

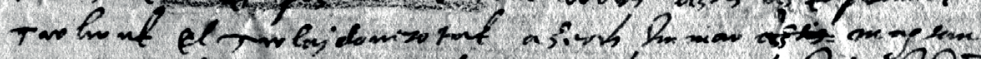

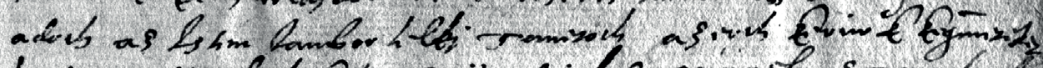

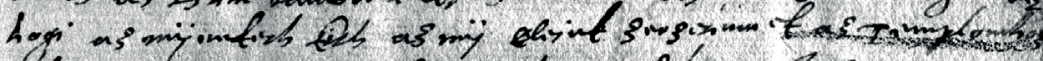

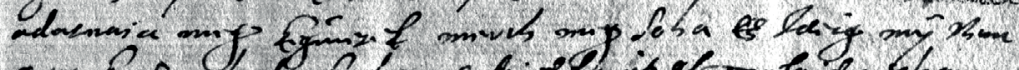

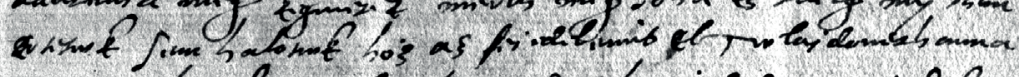

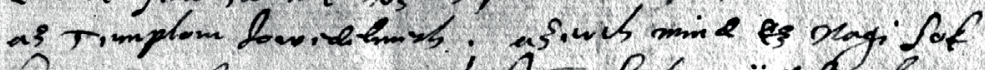

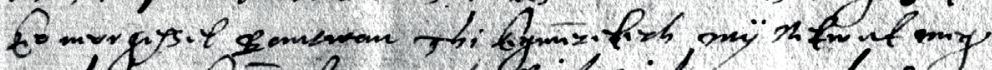

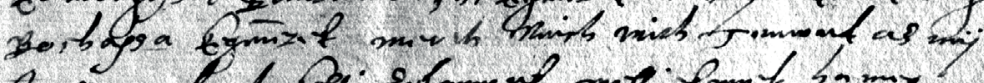

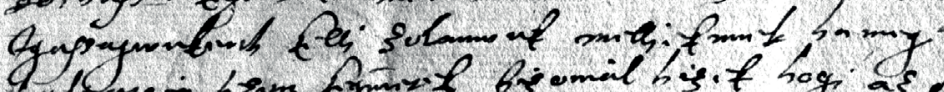

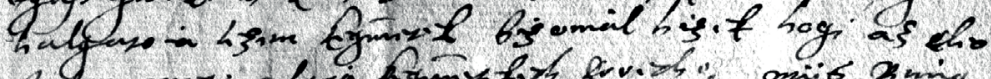

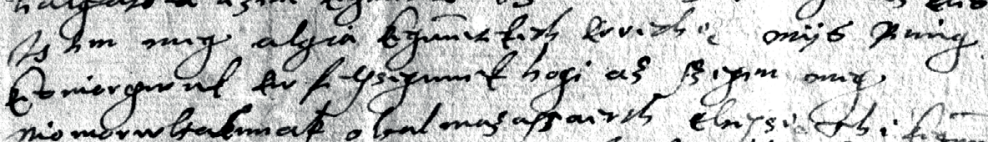

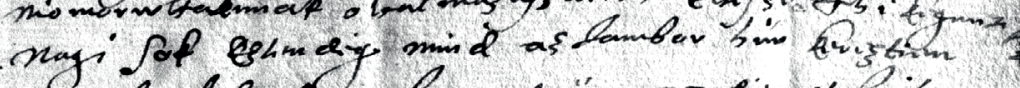

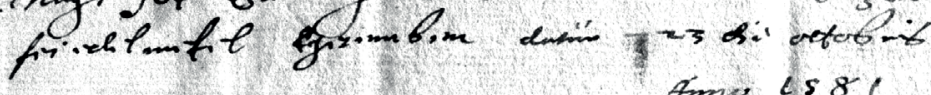

$$
\begin{aligned}
& \text { Armo } 4581 \\
& \text { As s.xin my nis montas, }
\end{aligned}
$$


Mind ezekreol supplicalwnk thi keḡmeteknnek minth keḡmes wrainknnak hogi meg halgatna keḡmetek az mj keoneorgesw̄keth merth ezeketh az niomorwssagokath nem eleg hogi meg Jellenttiwk de megis akkariwk bizonnettanj hogi ezek az nagi niomorwssagok mÿ raitwnk mind Igi wannak kik ennek eleoten miraitwnk soha nem woltak

ha nem chak ez keth kapitan keolthę mÿ reank kÿ miath Immar szinthen el niomorotwnk melli dolgokerth szinten Ew Naghoz < kirel> kirali kephez akkartwnk mennÿ de mjwel hogi az Isten thi kegmeteketh Ide hoztha azerth akkariwk kegmetekek kialtanÿ minden Igazssagwnkath hogi meg tekentwen az eleo Istennek Igassagath es az mÿ niomorwssaginkath thi kegmetek hagion minden Jo keḡmes walazzal ezenis supplicalẅnk thi kegmeteknnek hogi mÿ nekwnk wolth az egihazhoz walo monw"nk mellieth mÿ epetettwnk de miwel hogi mÿ nekw”nk temetonk lelki paztorronk nem wolth aztis az kapitaniok twlwnk el twlajdonetotak azerth Immar $<$ aztis $>$ mastan adoth az Isten Jambor lelki tanetoth azerth keriwk kegmeteket hogi az mÿenketh kith az mÿ eleink zerzetennek az templomhoz adatnaia meg keḡmetek merth meg soha ez Ideig mÿ nem ertetwk sem halotwk hoz az feiedelemis el twlaidonethanna az templom Jowedelmeth . azerth mind ez nagi sok keoneorgessel Bantwan thi keḡmeteketh mÿ nekwnk meg Bochassa kegmetek merth ninch mith tennwnk az mÿ Igassagwnkertth kelli zolanwnk mellieknnek ha meg halgatoia lezen kegmetek bizonial hizek hogi az eleo Isten meg algia keḡmeteketh errethę mÿs penig keoniorgwnk ew felssegenek hogi az szegen meg niomorwltaknnak ${ }^{11}$ oltalmazassaerth $^{12}$ eltessę thi kegmeteket ${ }^{13}$ nagi sok eztendeig mind az Jambor hiw kereztien feiedelmekel egetemben datw $<$. $>23$ die octobris Anno 1581 Az zegen meg niomorwlth Inotaj Jambor polgarok

\footnotetext{
${ }^{11} \mathrm{Az}$ első $k$ javított betü.

${ }^{12}$ A második $s z$-ből javított betü.

${ }^{13}$ A szó vége a lap szélén lekanyarodik.
} 


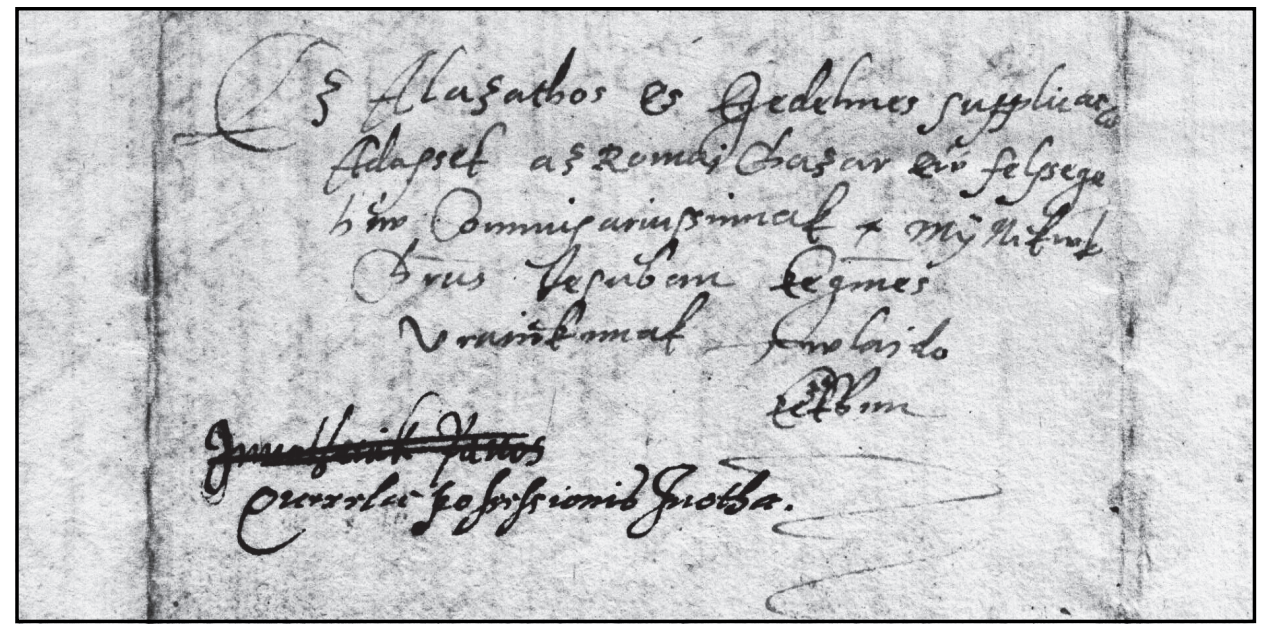


Kivvül:

Ez Alazathos es Egedelmes supplicatio Adassek az Romaj Chazar ew" felssege hiw Commisariussinnak <.> Mÿ Nekw̄k Chrus Jesūban keḡmes Vrainknnak twlajdo kezekben ${ }^{14}$

Más kézzel írva:

$<$ Innothaiak Panos $>$

querelae possessionis Inothae.

${ }^{14} \mathrm{~A}$ ze betükapcsolat interlineáris betoldás. 
Co

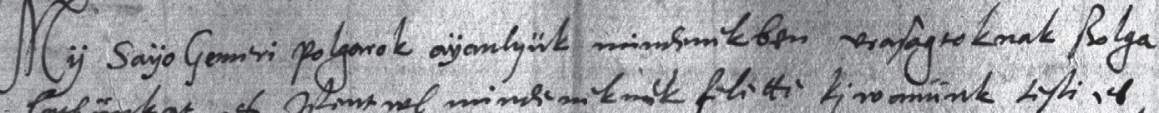

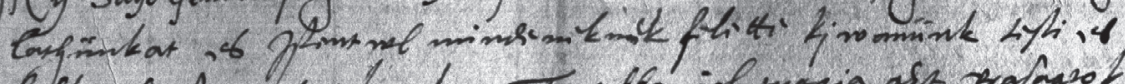

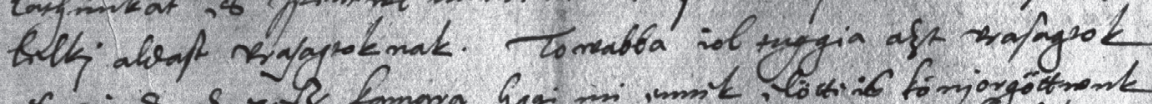

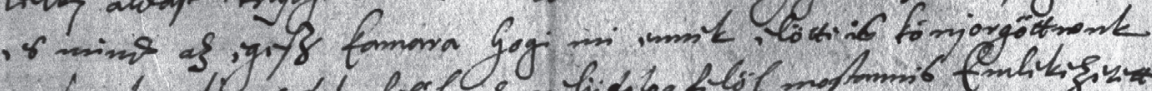

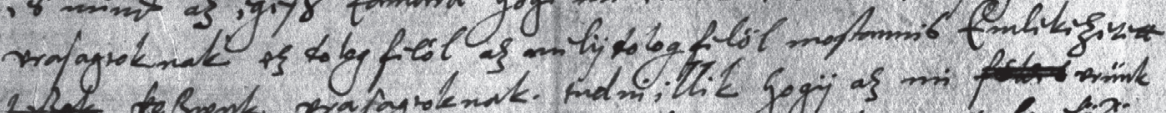

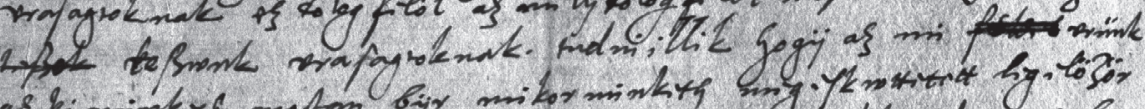

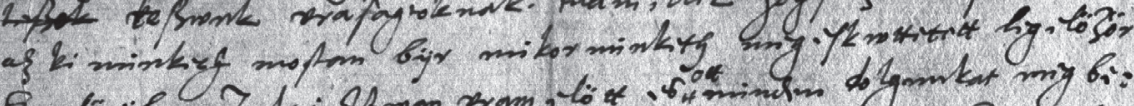

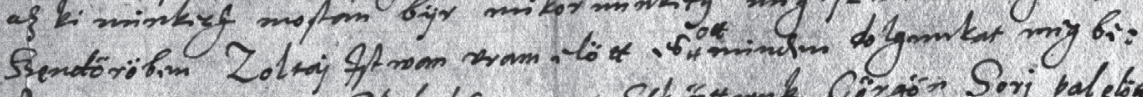

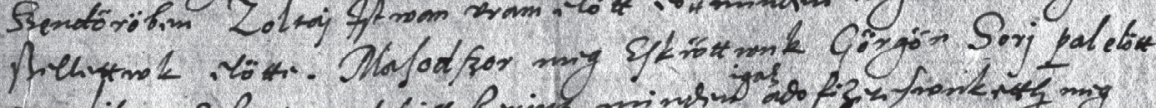

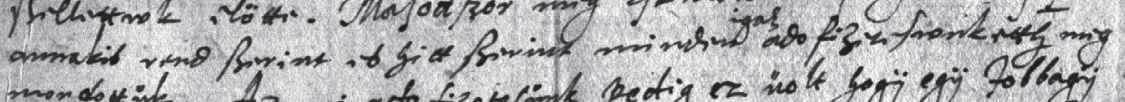

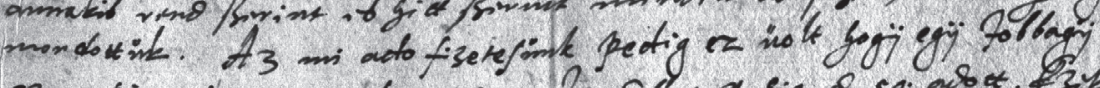

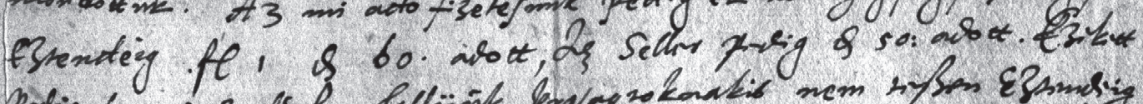

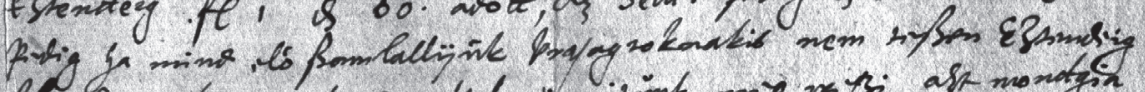

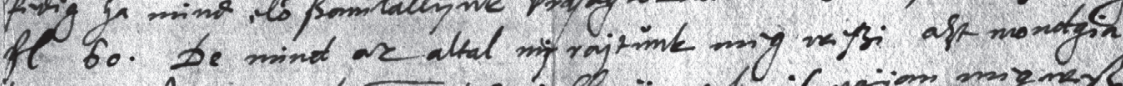

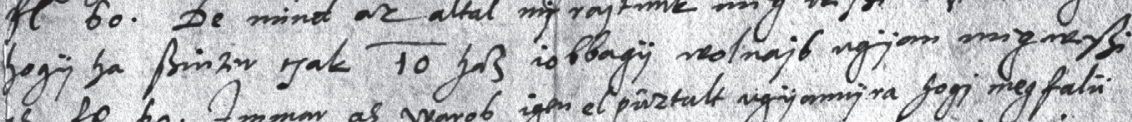

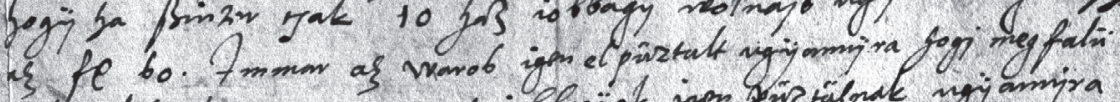

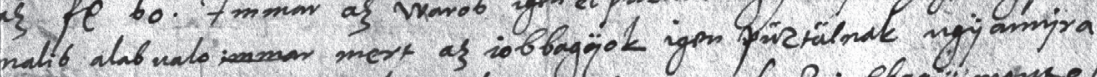

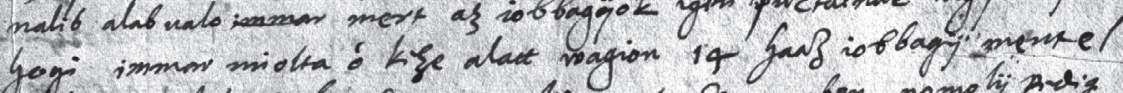

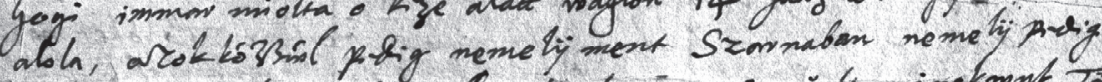

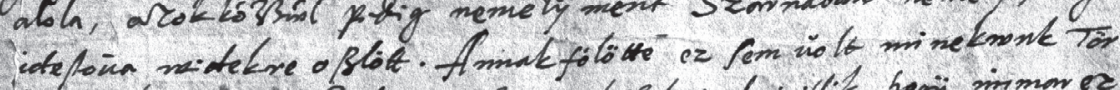

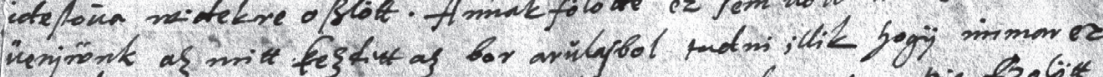

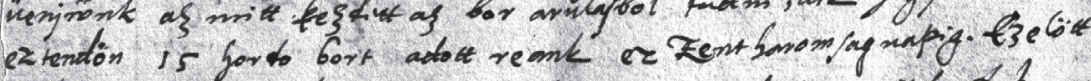
nab nrajuk pecty nem aumat egji ertentoming negij bor bo borral

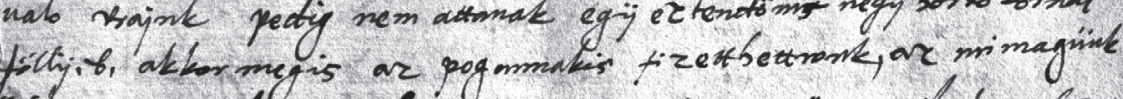

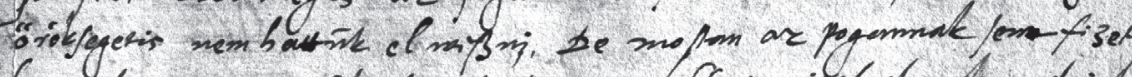

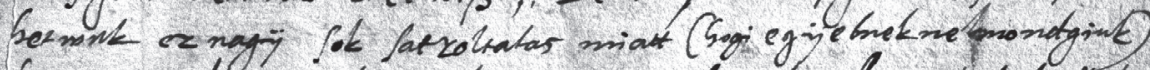

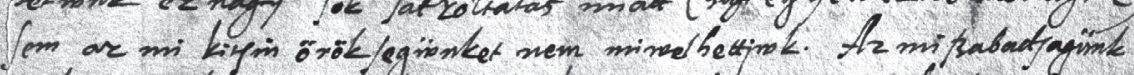

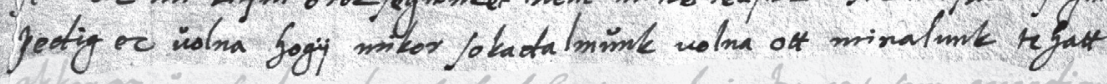




\section{I.17.}

Sajógömör, 1582. VI. Sajógömöri jobbágyok levele.

Mÿ Saÿo Gemeri polgarok aÿanlyük mindenekben vrasagtoknak szolga lathünkat es Istentwl mindeneknek felette kjwanünk testi es lelkj aldast vrasagtoknak. Towabba iol tuggia azt vrasagtok es mind az egesz kamara hogi mi ennek elötte is könjorgöttwnk vrasagtoknak ez dolog felöl az melÿ ${ }^{1}$ dolog ${ }^{2}$ felöl mostannis Emlekezetett $<$ teszok $>$ teszwnk ${ }^{3}$ vrasagtoknak. tudni illik hogÿ az mi < földes $>$ vrünk az ki minketh mostan bÿr mikor minketh meg eskwttetett leg elözör Szendöröben Zoltaj Istwan vram elött es ott ${ }^{4}$ minden dolgunkat meg beszelletwk elötte. Masodszor meg Eskw"ttwnk Görgön Sorj pal elött annakis rend szerint es hitt szerint minden igaz ${ }^{5}$ ado fizeteswnketth meg mondottük. Az mi ado fizetesünk pedig ez üolt hogÿ egÿ Jobbagÿ Eztendeig florenorum 1 denariorum 60. adott, Az Seller pedig denariorum 50: adott. Ezekett

pedig ha mind elö szamlallÿük Vrasagtoknakis ${ }^{6}$ nem teszen Eztendeig florenorum 60. De mind az altal mj rajtünk meg veszi azt mondgia hogÿ ha szinten tsak 10 haz iobbagÿ wolnajs ugÿan meg weszi az florenorum 60. Immar az waros igen el püztult ugÿannjra hogj meg falü nalis alab ualo <immar> mert az iobbagÿok igen püztülnak ugÿannjra hogi immar miolta ö keze alatt wagion 14 haaz iobbagÿ ment el alola, azok közzw"l pedig nemelÿ ment Szarnaban nemelÿ pedig idestoüa widekre oszlött. Annak fölötte ez sem üolt mi nekwnk Tör üenjw"nk az mitt kezdett az bor arülasbol tudni illik hogÿ immar ez eztendön 15 hordo bort adott reank ez Zent haromsag napig. Ez elött ualo vrajnk pedig nem attanak egÿ eztendönis ${ }^{7}$ negÿ hordo bornal föllÿeb, akkor megis az pogannakis fizetthettwnk, az mimagünk öröksegetis nem hattük el wesznj. De mostan az pogannak sem ${ }^{8}$ fizet hetwnk ez nagÿ sok saczoltatas miatt (hogi egÿebnek ne mondgiuk ${ }^{9}$ ) sem az mi kitsin öröksegẅnket nem miwelhettjwk. Az mi szabadsagünk pedig ez üolna hogÿ mikor sokadalmünk uolna ott minalunk tehatt

\footnotetext{
${ }^{1}$ Az $m$ megkezdett $a$-ból javított betü.

${ }^{2} \mathrm{~A} d$ javított betü.

${ }^{3} \mathrm{~A} t$ javított betü.

${ }^{4}$ A szó interlineáris betoldás, jellel a helyére utalva.

${ }^{5}$ A szó interlineáris betoldás.

${ }^{6} \mathrm{Az} n$ javított betü.

${ }^{7} \mathrm{~A} s$ javított betü.

${ }^{8} \mathrm{Az} m$ javított betü.

${ }^{9} \mathrm{Az} m$ törölt betüre van írva.
} 
akkoraz inmofrak nolne kabad boxt anulmi be azt fem eryedimeg

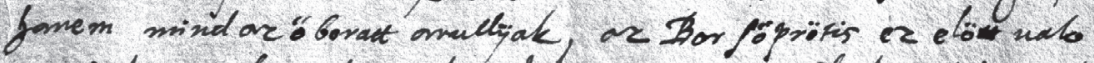
vinjuk mind ammat atak of kik az 6ort 4 arn loak, Whfm nats

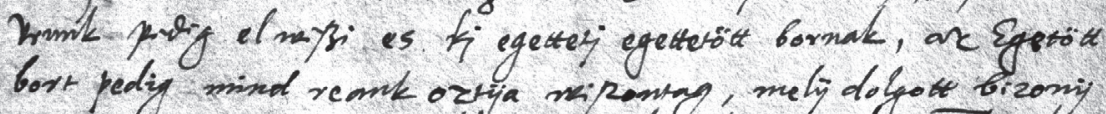

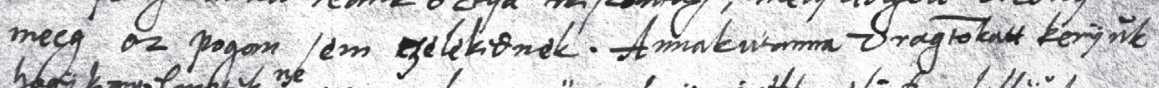

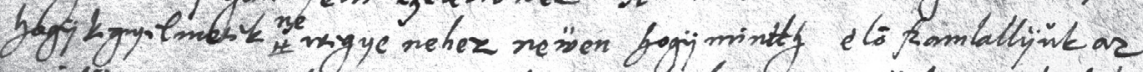

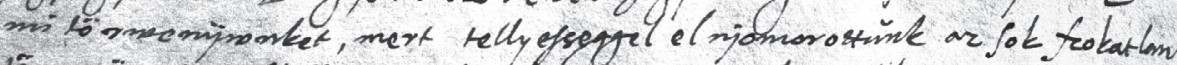
tormeni miat Mellyet motam kez mirojtink Heleked nj.

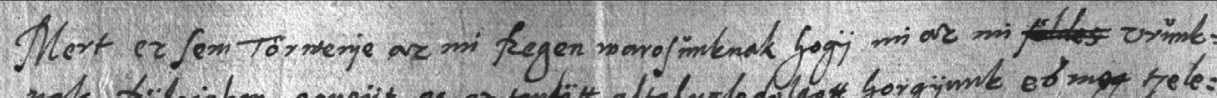

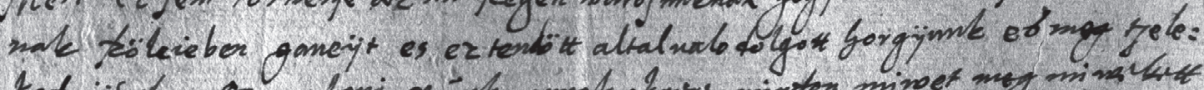

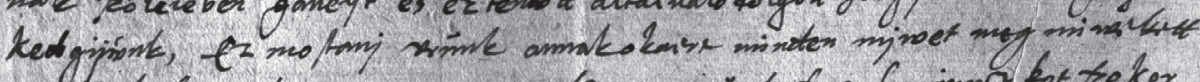

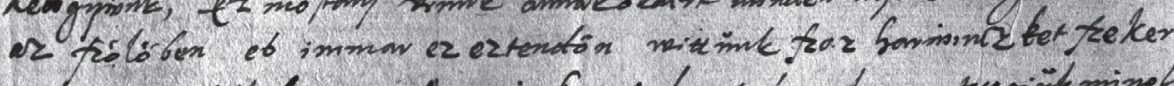
gomeji az firtsben, mo pan mis fet feekeret ker te nem rygin̈kminek

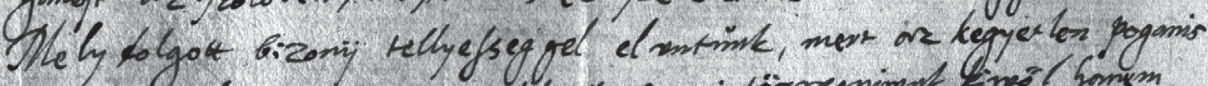

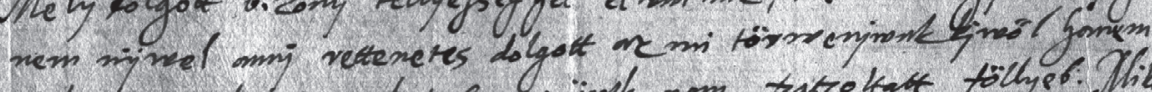

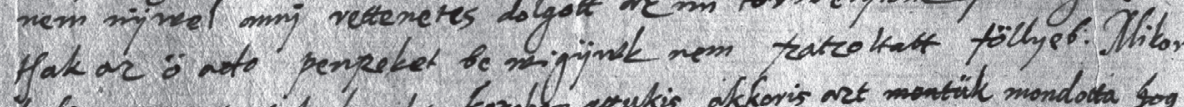

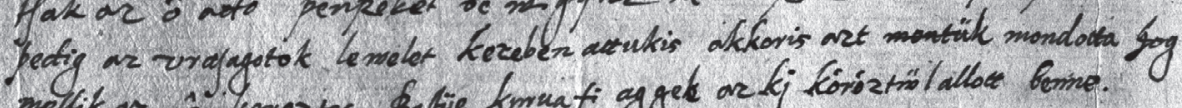

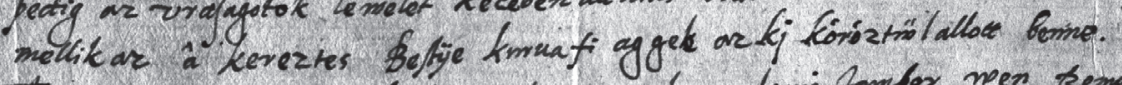

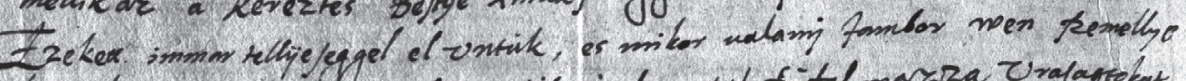

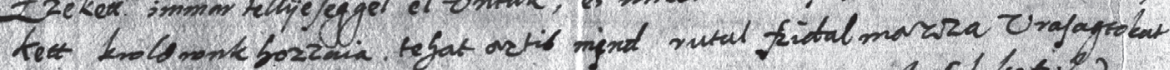

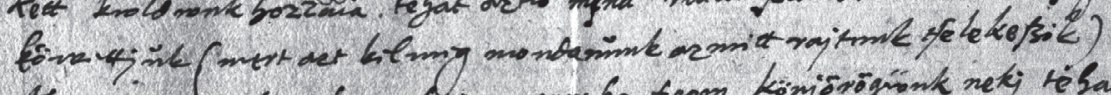

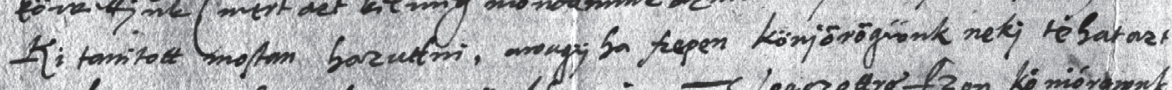

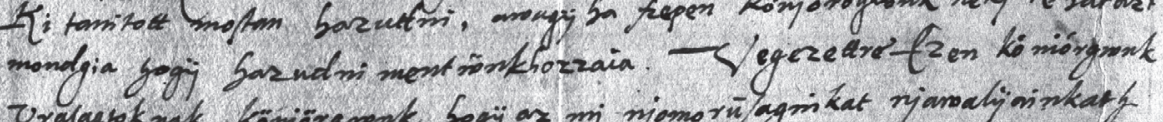

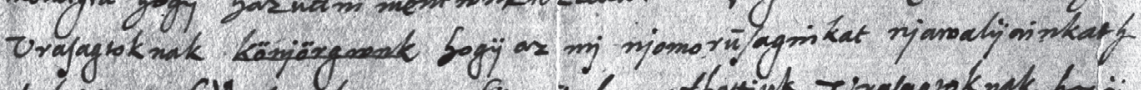

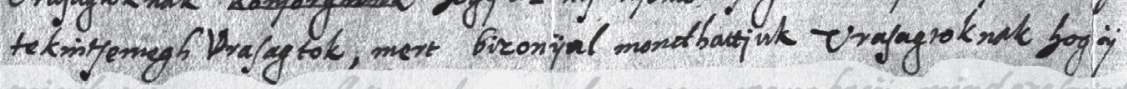


akkor az üarosnak uolna szabad bort arulni. $\mathrm{De}^{10}$ azt sem engedj meg hanem mind az ö boratt arullÿak, az Bor söprötis ez elött ${ }^{11}$ ualo vrajnk mind annak attak az kik az bort ki arültak, Mostan ualö Vrunk pedig el weszi es kj egettetj egettetött bornak, az Egetött ${ }^{12}$ bort pedig mind reank oztÿa wiszontag, melÿ dolgott bizonÿ meeg az pogan sem czelekednek. ${ }^{13}$ Annakutanna vrāgtokatt kerÿük hogÿ kegyelmetek ne ${ }^{14}$ wegye nehez neẅen hogÿ mintth ${ }^{15}$ elö szamlallÿük az mi törwenÿwnket, mert tellyesseggel el njomorottünk az sok szokatlan törwenÿ miatt Mellyet ${ }^{16}$ mostan kezd mirajtünk tselekednj.

Mert ez sem Törwenje az mi szegen warosünknak hogÿ mi az mi < földes $>$ vrünknak szöleieben ganeÿt es eztendött ${ }^{17}$ altal ualo dolgott horgÿunk es meg tselekedgÿwnnk, Ez mostanj vrünk annakokaert minden mjwet meg miweltett az szölöben es immar ez eztendön wittünk szaz harmincz ket szeker ganejt az szölöben, mostannis ket szekeret ker de nem tuggiük minek Mely dolgott bizonÿ tellyesseggel el vntünk, mert az kegyetlen poganis nem mÿwel annj rettenetes dolgott az mi törwenjwnk kjwöl hanem tsak az ö ado penzeket ${ }^{18}$ be wigÿwk nem szatzoltatt föllyeb. Mikor pedig az vrasagotok lewelet kezeben attukis akkoris azt $<$ montük $>$ mondotta $<$ hog $>$ mellik az a ${ }^{19}$ kereztes Bestÿe kuruafi aggeb ${ }^{20}$ az kj köröztẅl allott benne.

Ezekett immar tellÿeseggel el vntuk, es mikor ualamj Jambor wen szemellye kett kwldwnk hozzaia. tehat aztis mjnd ${ }^{21}$ rutul szidalmazza Vrasagtokat köwettjük (mert azt kel meg mondanünk az mitt rajtunk tselekeszik) Ki tanitott mostan hazudni, awagÿ ha szepen könjörögẅnk nekj tehat azt mondgia hogÿ hazudni mentẅnk hozzaia. Vegezettre Ezen köniörgwnk vrasagtoknak < könjörgwnk> hogÿ az mj njomorüsaginkat njawalÿainkath tekintsemegh Vrasagtok, mert bizonÿal mondhattjuk Vrasagtoknak hogÿ

\footnotetext{
${ }^{10} \mathrm{~A} D d$-böl van javítva.

${ }^{11}$ A $t$ t feltehetően javított betűkapcsolat.

${ }^{12}$ A második $e$ fölötti jel szándéktalannak látszik.

${ }^{13} \mathrm{~A} c$ javított betü.

${ }^{14}$ A szó interlineáris betoldás, jellel a helyére utalva.

${ }^{15} \mathrm{~A} t t d$-böl javított betünek látszik.

${ }^{16} \mathrm{Az} M$ javított betünek tünik.

${ }^{17} \mathrm{~A} d$ feltehetően javított betü.

${ }^{18} \mathrm{~A} z$ p -ből javított betü.

${ }^{19} \mathrm{Az}$ a fölötti jel funkciója ismeretlen.

${ }^{20} \mathrm{~A} b$ k-ból javított betü.

${ }^{21}$ A $j$ valószínüleg e-ből van javítva.
} 

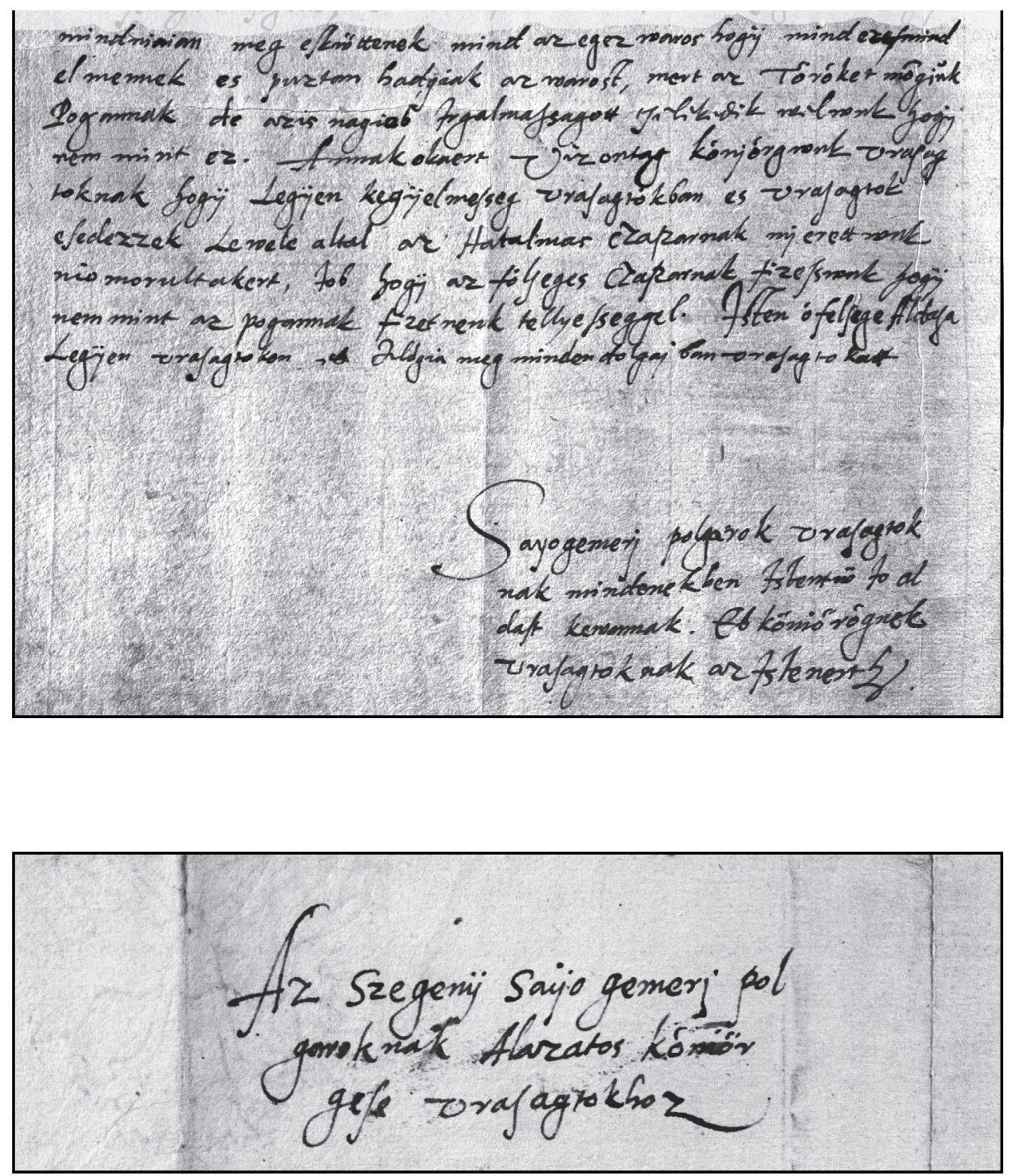
mindniaian meg eskw"ttenek mind az egez waros hogÿ mind <ezesmind $>$ el mennek es puztan hadgiak az warost, mert az Töröket mōgiük Pogannak de azis nagiob ${ }^{22}$ Irgalmassagott tselekedik welwnk hogÿ nem mint ez. Annakokaert Vizontag könjörgwnk vrasag toknak hogÿ Legÿen kegÿelmesseg vrasagtokban es vrasagtok esedezzek Lewele altal az Hatalmas Czaszarnak mj erettwnk niomorultakert, Job hogÿ az fölseges Czaszarnak fizesswnk hogÿ nem mint az pogannak fizetnenk tellyesseggel. Isten öfelssege Aldasa Legÿen vrasagtokon es Aldgia meg minden dolgajban vrasagtokatt

Sayogemerj polgarok vrasagtok nak mindenekben Istentẅ Jo al dast kewannak. Es köniörögnek vrasagtoknak az Istenert etc.

Kívül:

Az Szegenÿ Saÿo gemerj pol garoknak Alazatos köniör gese vrasagtokhoz

${ }^{22} \mathrm{Az} o$ valószínüleg $a$-ból javított betű. 


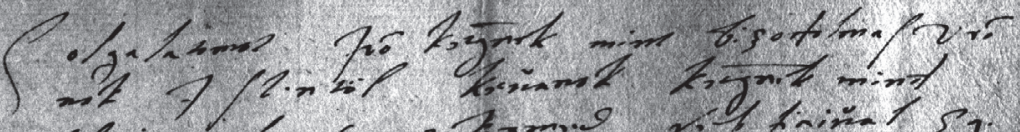

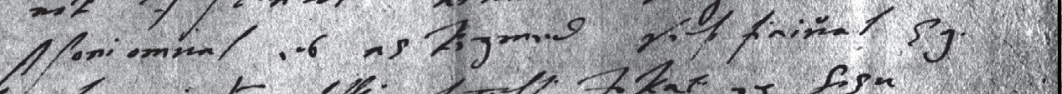

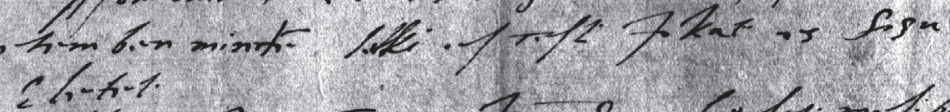

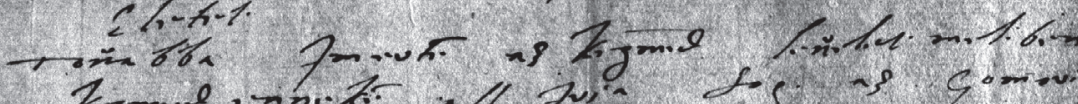

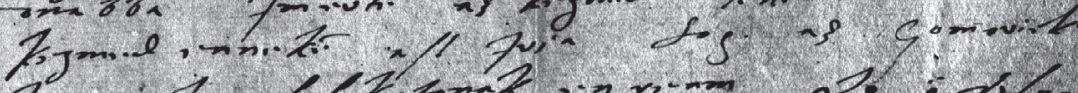

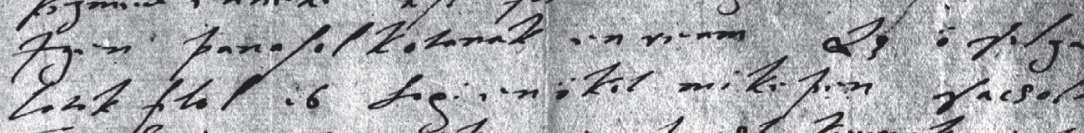
LIf

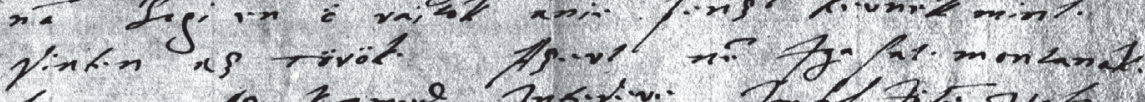

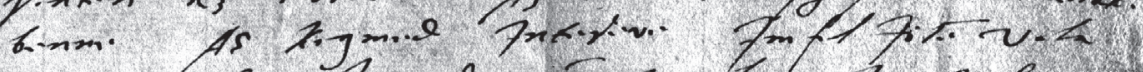

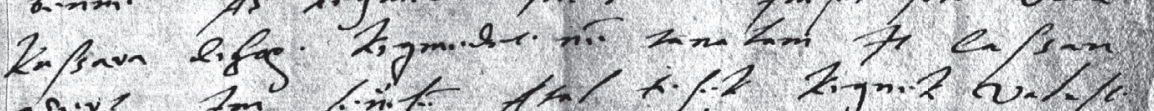

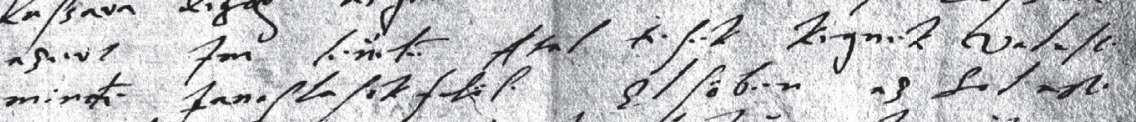

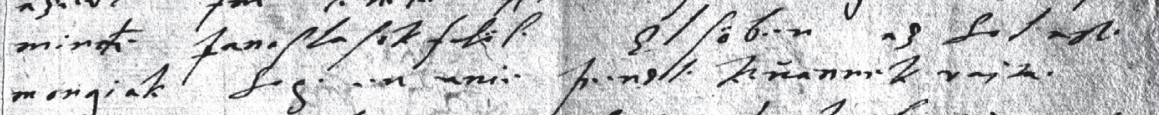

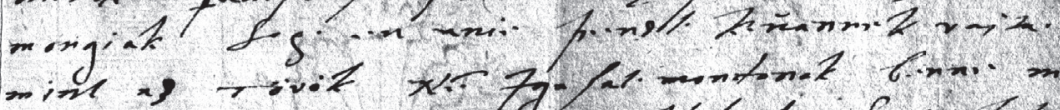

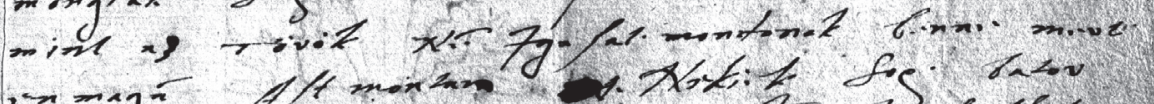

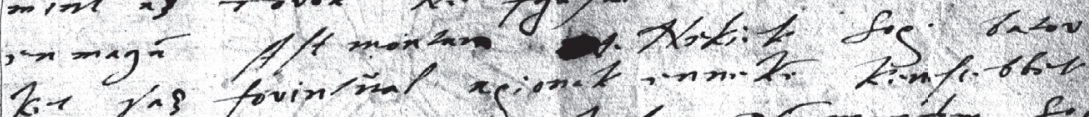

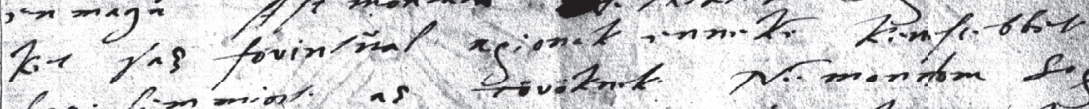

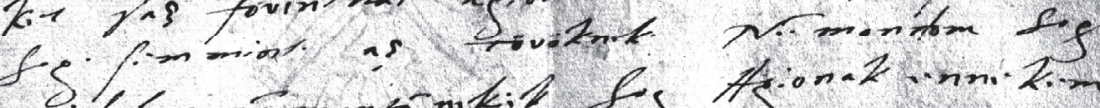

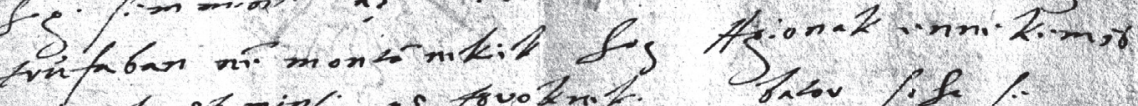

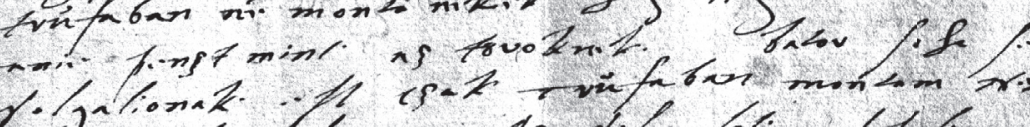

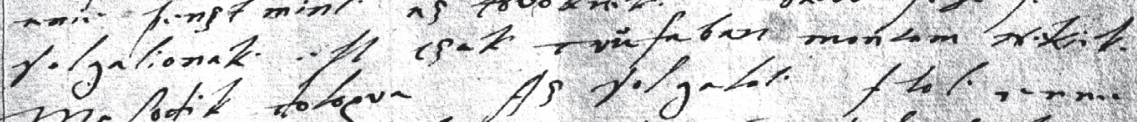

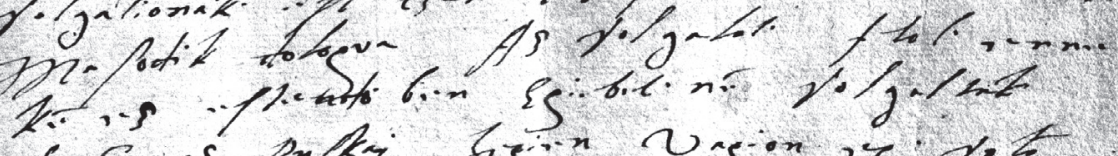

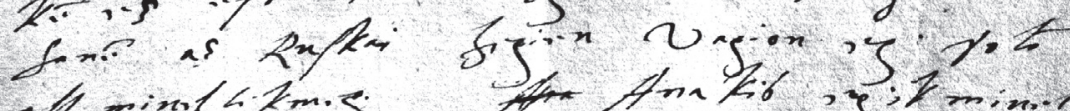

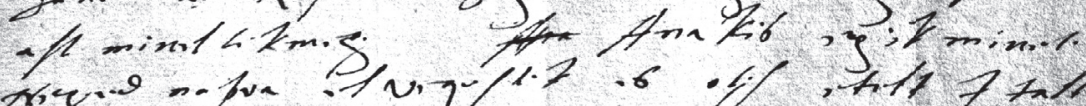

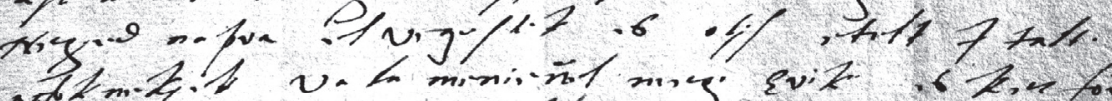

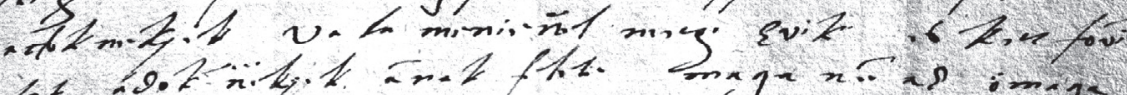

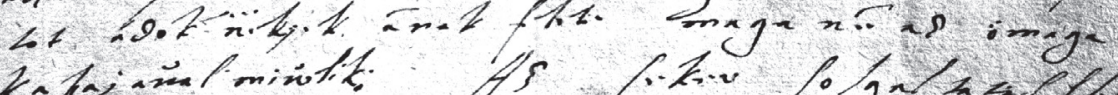

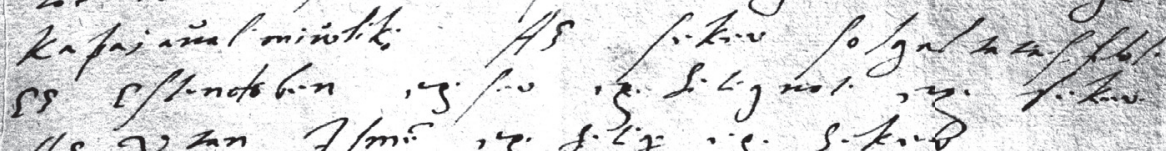

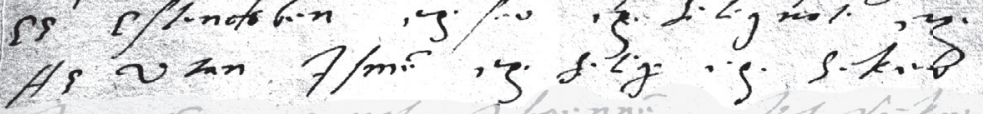




\section{I.18.}

Kassa, 1582. VI. Panka Péter levele.

Solgalatomot Irō keḡnek mint bizodolmas Vrō

nak Istentöl keŭanok keḡnek mind

Asoniomual es az keḡmed sep fiaiŭal Eg.

etemben ${ }^{1}$ minde lelki es Testi Jokat es hozu

Eletet.

Toŭabba Im ertē az keḡmed leŭelet $\cdot$ meliben

keḡmed enneke ast Iria hog· az Gomoriek·

Igen panasolkotanak en ream $\mathrm{Az}^{2}$ ö solga

latok felol es hogi en ököt mikepen saczoltat

nā hogi en ö raitok anie penzt kernek mint.

sinten az Török · Azert ne Igasat montanak

benne Az kegmed Intesere Im fel Jöte vala

Kassara dehog $\cdot$ kegmedet $\cdot n \bar{e}$ tanatam It Cassan

azert Im leŭele Atal tesek kegnek valast.

mindē panaslasok felöl- Elsöben az hol azt .

mongiak hog - en anie penzt $\cdot$ keŭannek rajta·

mint az Török Nê Igasat · mondonak benne mert

en maga Ast montam < .. > Nekiek hog $\cdot$ bator

ket saz forintŭal agionak enneke keuesebbet

hog· sem mint· az Töröknek · Ne mondom hog

trŭfaban ne montā nekik hog Agionak ennekemes

anie penzt mint $\cdot$ az toroknek b bator soha se

solgalionak ' est czak Trŭfaban' montam Nekiek·

Masodik dologra Az solgalat· felol· enne

$\mathrm{ke}$ ez estendö ben Egiebel $\cdot$ ne solgaltak

hane az Ruskai hegien vagion eg solō

ast miueltekmeg $\cdot<$ Ana $>$ Anakis egik miuet

Neged napra el vegestek es otjs etelt Italt.

adok nekjek vala menieŭel meg. Erik es ket fori

tot adok nekjek anak felete maga ne az ömaga

kapaiaŭal miŭelik Az seker solgaltatas felol.

Ez Estendöben eg · ser eg · hetig uot · eg · seker

Az vtan Ismē eg $\cdot$ hitig eg seker

${ }^{1}$ A levélben bizonyos szó-, ill. sorvégi betűk után (föként a $k$, $t$ és $g$ betűket, de olykor más betűket követően is) gyakran látható egy felemelt pont, amely azonban nem elég rendszeres ahhoz, hogy az adott betü részének legyen tekinthetö, ugyanakkor elválasztójelnek vagy központozási jelnek is csak olykor lehet(ne) értelmezni.

${ }^{2} \mathrm{Az} A$ javított betűnek látszik. 

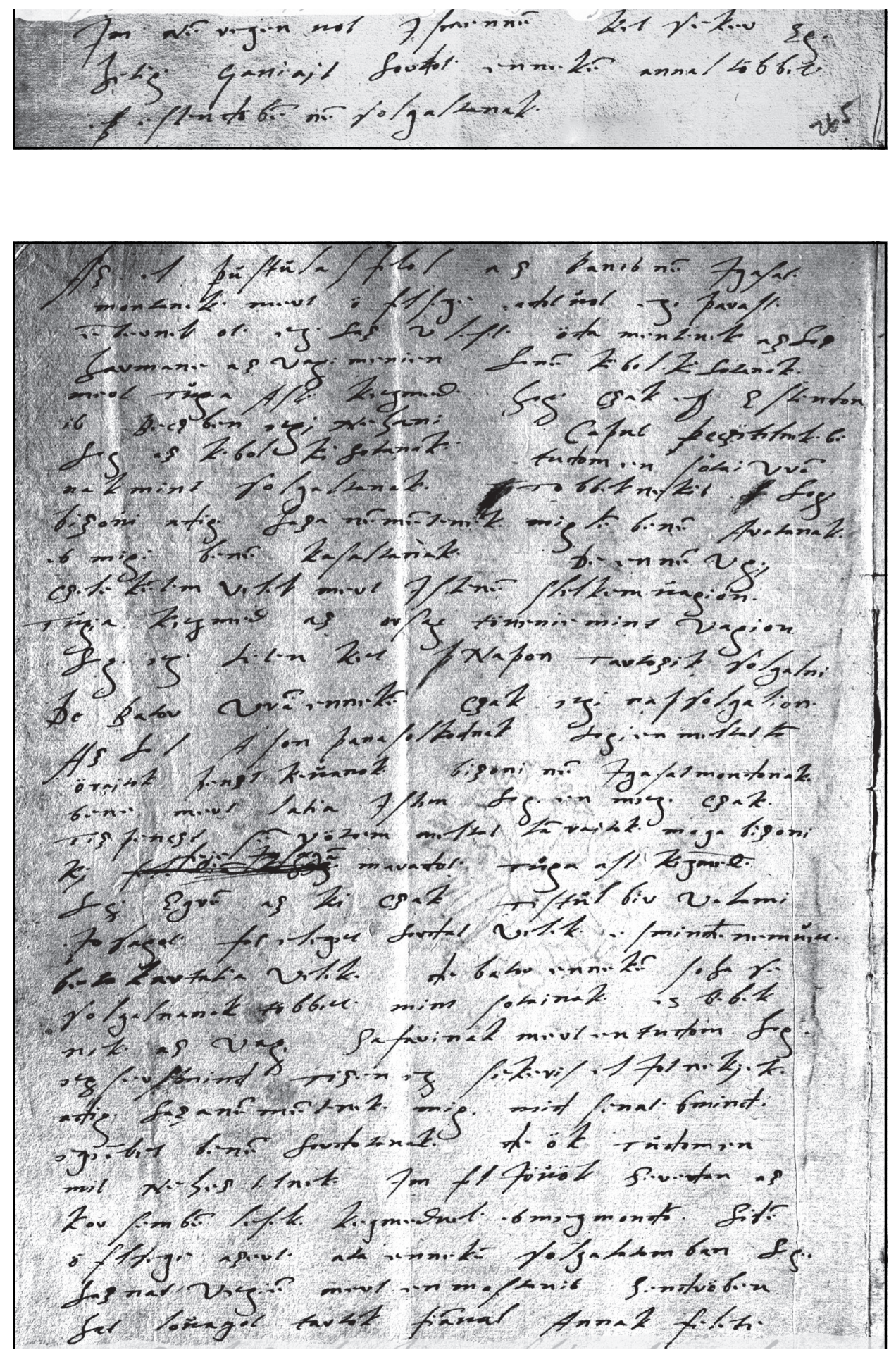
Im Nē regen uot Ismenne ket seker Eg. hetig - ganiajt hordot enneke annal többet $\mathrm{ez}^{3}$ estendöbe $\overline{\mathrm{e}}$ solgaltanak.

Az el pŭstŭlas felol az Banis nē Igasat• montanak mert ö felsege adot ŭot eg · parast ebernek ot· eg · haz vlest öda mentenek azhoz harmane az vagi menien hanem kibol ki hotanak. mert Tŭga Ast· kegmed· hog · czak eg · Estendon is Beczben egi Nehani Caput peczetelnek be hog az kibol ki hotanak tudom en sotai vrā nak mint solgaltanak $\cdot<$ Jo $>$ Tobbeknekis $<\mathrm{h}>$ hog bizoni adig ' haza ne mētenek ' migle bene Aratanak es mig bene kasaltanak ' De en nē vgi czeleketem velek mert Istenē slelkem ŭagion.

Tŭgia kegmed az orsag töuenie mint vagion hog eg · heten ket $<\mathrm{p}>$ Napon Tartozik solgalni De Bator vrā enneke czak egi nap solgalion.

Az hol Ason panasolkodnak hogi en meltatla öraitok penzt keŭanok · bizoni nē Igasat mondonak bene mert latia Isten hog en meg czak Tiz penczt se vötem mostal tā raitok $\cdot$ maga bizoni $\mathrm{kj}<\mathrm{fel}$... . hog $>$ feje Josaga maradot· Tŭga ast keḡmed hog $\cdot$ Egre az ki czak Tistŭl bir valami Josagot fol eleget hordat velek· esmindē nemŭet be takartatia velek de bator enneke soha se solgalnanak többet $\cdot$ mint sotainak es bebek nek· az vag · Safarinak mert en tudom hog egsersmind ${ }^{4}$ Tizen eg sekeris el Jot nekjek

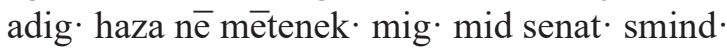
egiebet benē hordotanak de ök Tŭdom en mit Neheztelnek· Im fel Jöŭök Seredan az kor sembe lesek k kegmeduel· es meg mondō hisē ö felsege azert ata enneke solgalatomban hog. haznat vegie mert en mostanis Zendröben hat loŭagot tartok fiāual ${ }^{5}$ Annak felete

\footnotetext{
${ }^{3} \mathrm{~A} z$ s-ből javított betü.

${ }^{4} \mathrm{Az} m$ másik betűből van alakítva.

${ }^{5} \mathrm{Az} u$ olvasata bizonytalan, esetleg $n$ is lehet.
} 

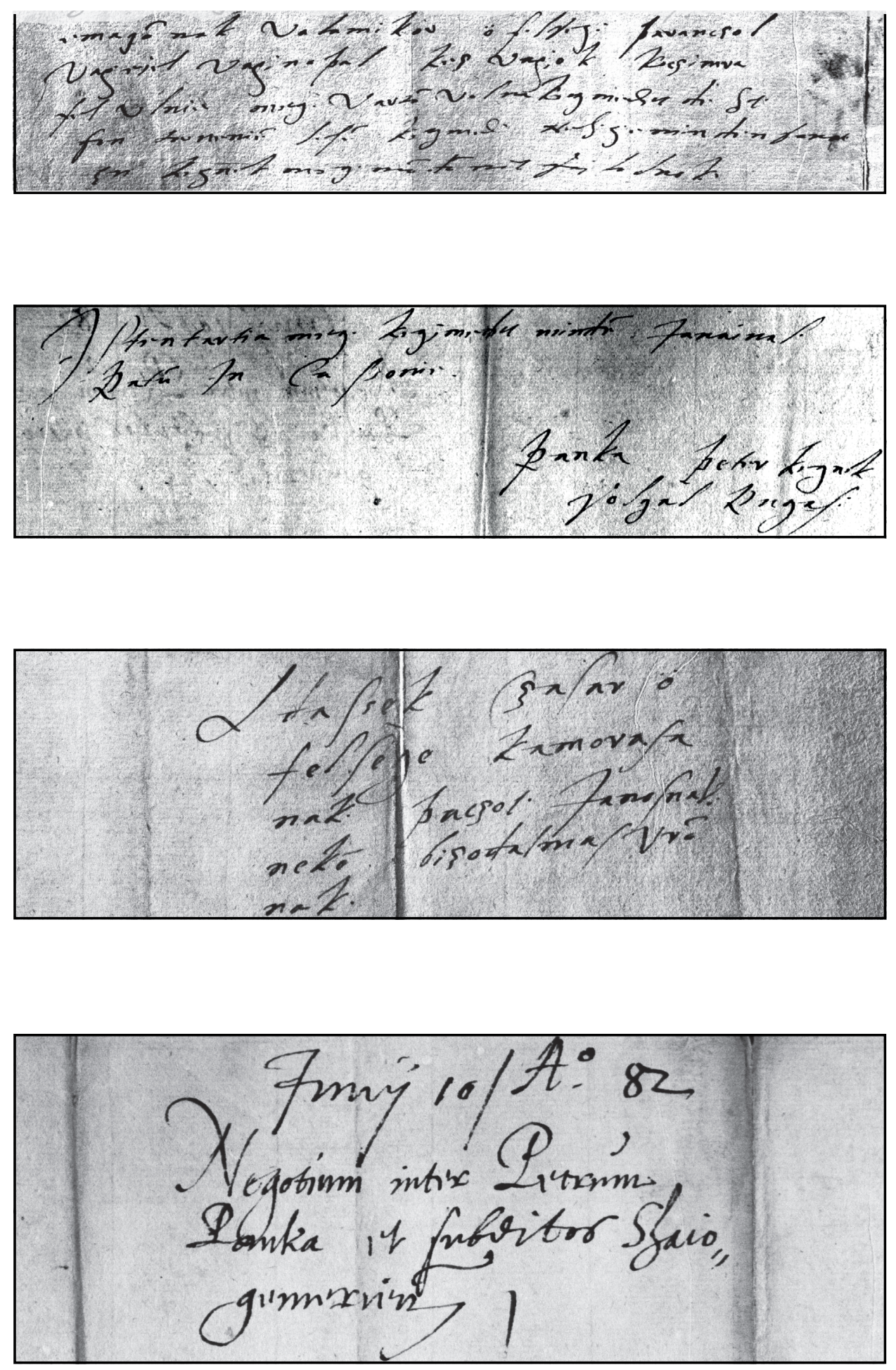
emagōnak valamikor ö felsege paranczol vag- eiel vagi napal kez vagiok koczimra fel vlnie meg · vartā volna kegmedet de het .

fon töruenie lese kegmed Nezze minden somat En kegnek meg mōta mit fajlalnak.

Isten tartia meg $\cdot$ kegjemedet minde Jauaiual Datum In Cassouie.

\author{
Panka Peter kegnek \\ solgal Rugasi
}

Kívül:

Adassek Czasar ö felsege kamorasa nak P Paczot· Janosnak nekō bizodalmas Vrō nak.

Más kézzel írva:

Junÿ 10 / Anno 82

Negotium inter Petrŭm

Panka et subditor Shajo-

gemeriensis / 
E 254 - 1582. dec. No. 2.

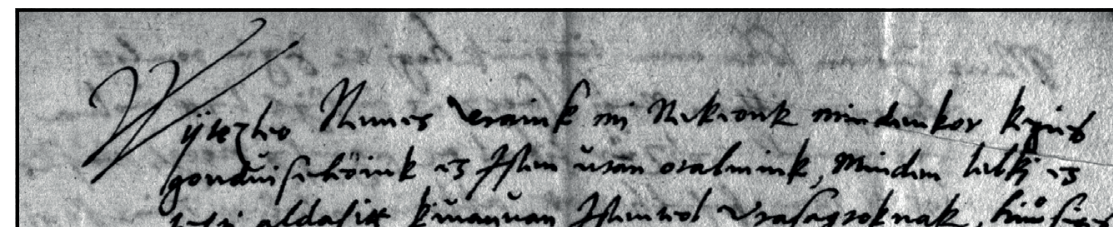

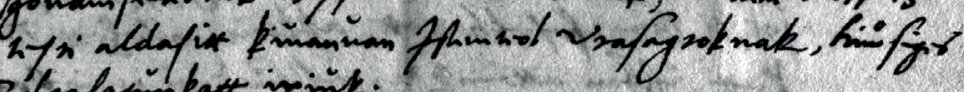
rogulasinkat inink.

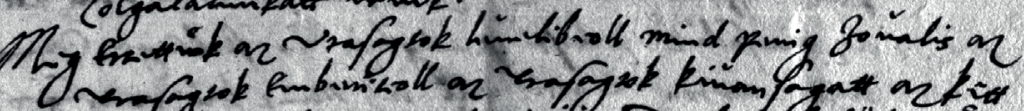

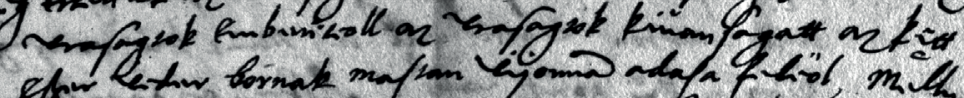

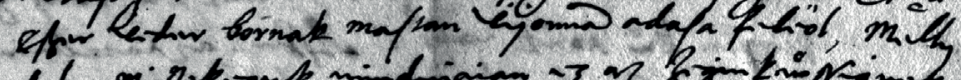

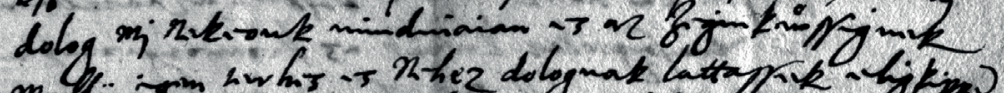

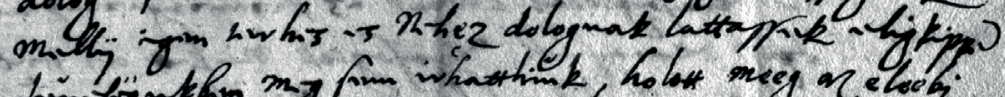

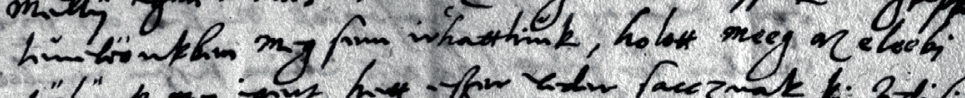

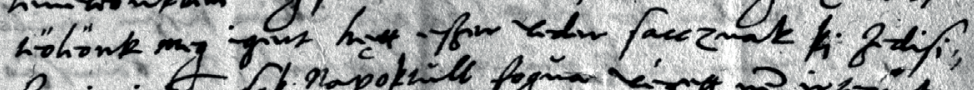

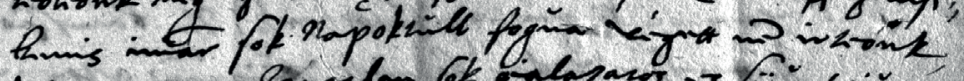

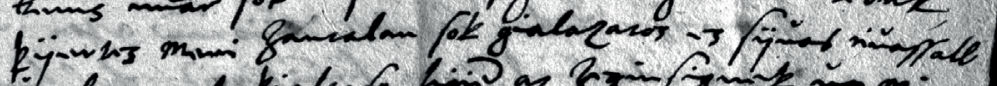

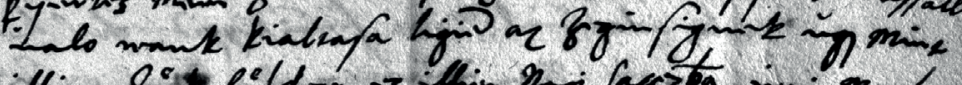

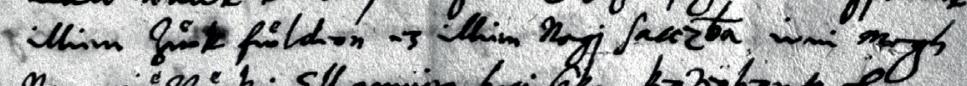

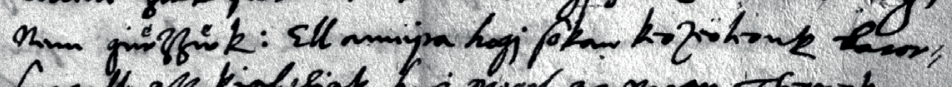

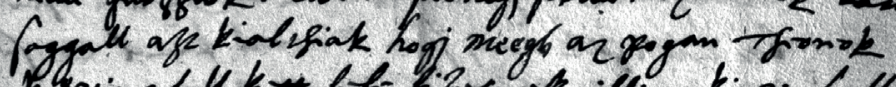

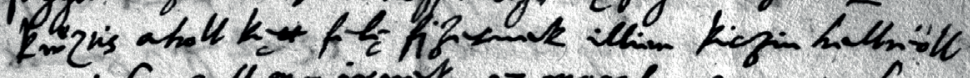

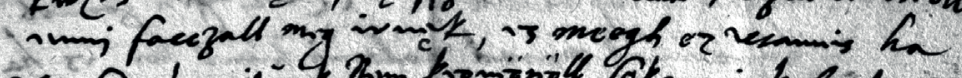

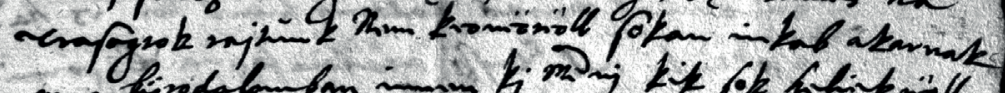

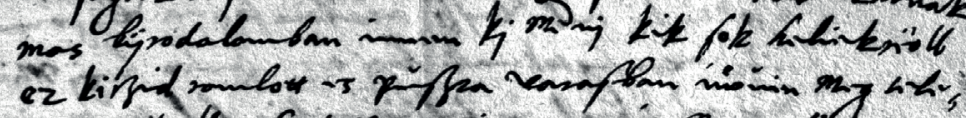

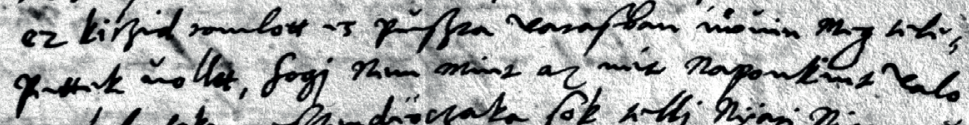

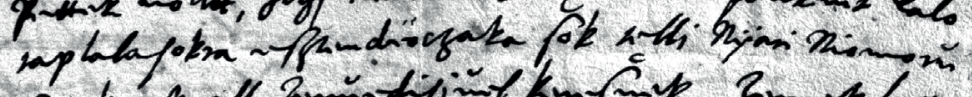

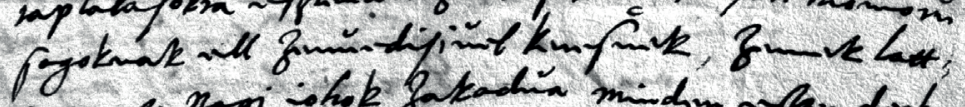

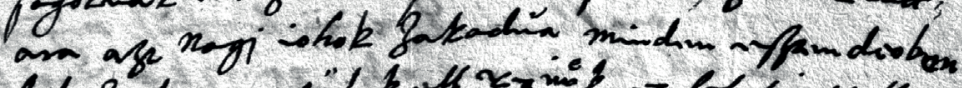

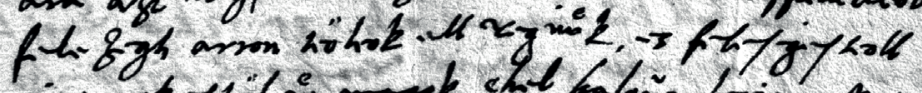

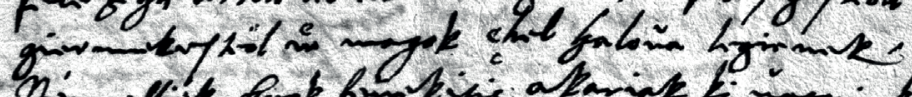

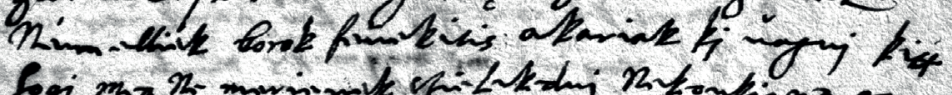

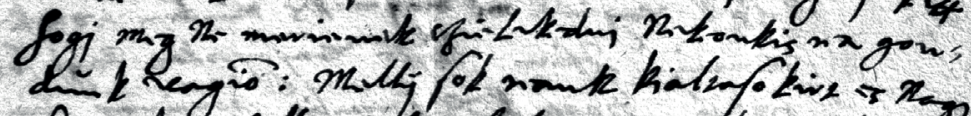

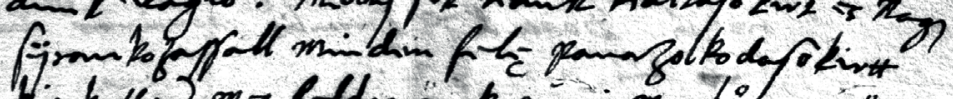

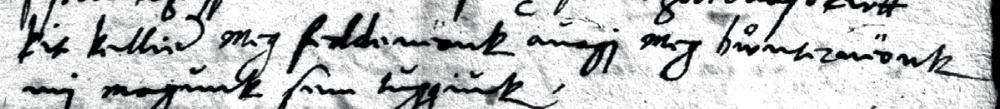
$\rightarrow$ m

1

110 


\section{I.19.}

Nagybánya, 1582. XII. 8. Nagybányai jobbágyok levele.

Wÿtezleo Nemes vraink mi Nekeonk Mindenkor kegies gondŭiseleöink es Isten ŭtan otalmink, Minden lelki es testi aldasitt kiŭanŭan Istenteol vrasagtoknak, hiwiesiges zolgalatŭnkatt iriǔk.

Meg Ertettw̌ ${ }^{\circledR} k$ az vrasagtok leǔelibeoll mind penig zoŭalis az vrasagtok Embereteoll az vrasagtok kiŭansagatt az kętt Eszer veder bornak mastan vÿonnā adasa felelöl, Mellÿ dolog mj Nekeonk mindniaian es az zegin kwsiessignek mellÿ igen terhes es Nehęz dolognak lattassek eligkippe leŭeleönkben meg sem irhatthiŭk, holott meeg az eleebi teöleönk meg igert hętt eszer veder saccznak ki zedisibenis imār sok napoktŭll fogŭa vegett ${ }^{1}$ ne irteönk, kÿertes meni zantalan sok gialazatos es sÿŭas riŭassall ŭalo reank kialtasa ligie az zeginsignek ŭgj mint illien zwe fiè fỉleon es illien Nagj sacczbā irni megh

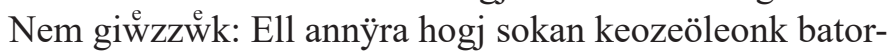
saggall azt kialthiak hogj meegh az pogan Theoreok kwżtis aholl kętt felę fjzetnek illien kiczin hellreöll ennj sacczall meg irnęk, es meegh ez vtannis ha vrasagtok rajtŭnk Nem keoneöreöll sokan inkab akarnak mas bÿrodalomban innen kj Mēnj kik sok heliekreöll ez kiczid romlott es pŭszta varasban iwüun Meg telepettek ŭolltt, hogj Nem Mint az mit Naponkint valo taplalasokra esztendeöczaka sok tęlli Nÿari Niomorŭ sagoknak ell zenŭedisiŭel keresnek, zemek lattara azt nagj iohok zakadŭa minden esztendeoben ${ }^{2}$ felezegh arron teöleok ell vegiw ${ }^{\mathrm{e}} \mathrm{k}$, es felesigesteoll giermekesteöl $\mathrm{e}$ magok ęhel haloŭa legienek, Nemelliek ${ }^{3}$ borok fenekitis akariak kj ŭagnj kitt hogj meg Ne merienek czielekednj Nekonkis rea gondŭnk vagiō: Mellÿ sok reank kialtasokirt es Nagj sÿrankozassall minden felę panazolkodasokirtt kit kellie meg feddeneönk aŭagj meg bwّentetneönk mj magŭnk sem tŭggiŭk,

\footnotetext{
${ }^{1}$ Az első $e$ fölötti vonás feltehetően szándéktalan.

${ }^{2}$ Az utolsó $e$ javított betü.

${ }^{3}$ L. az 1 . lábjegyzetet.
} 


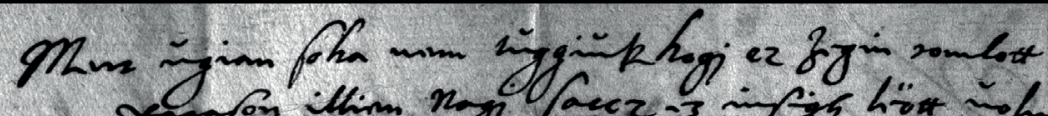

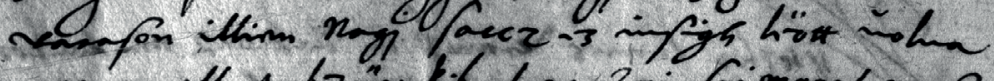

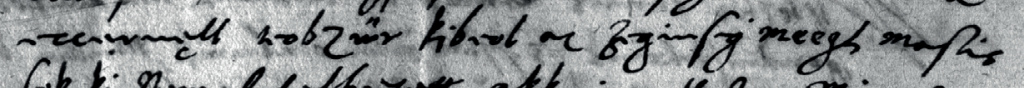

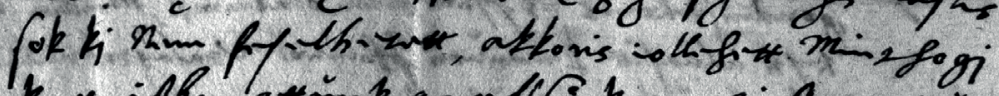

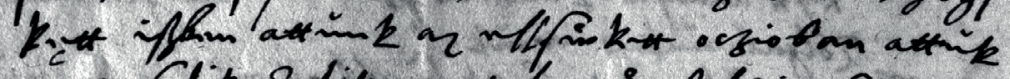

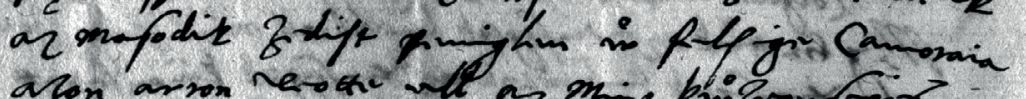

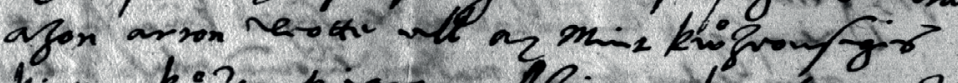

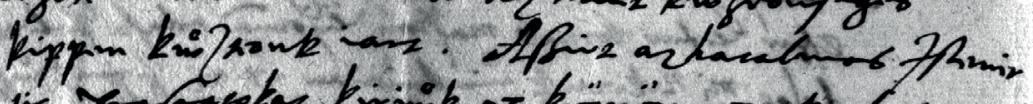

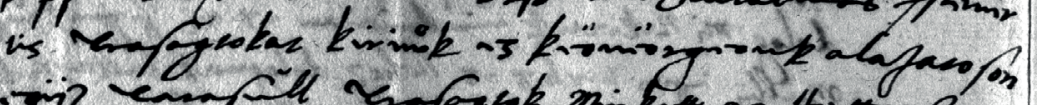

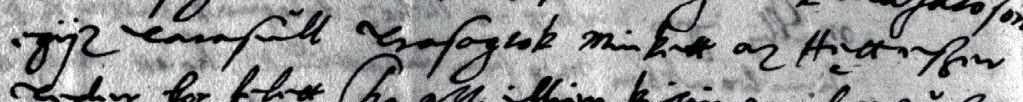

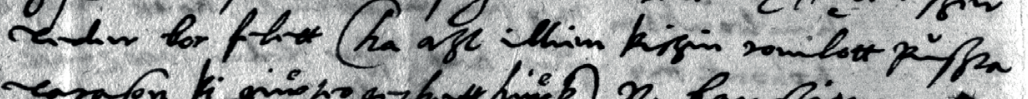

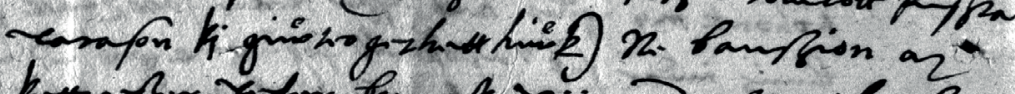

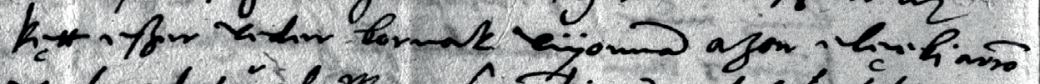

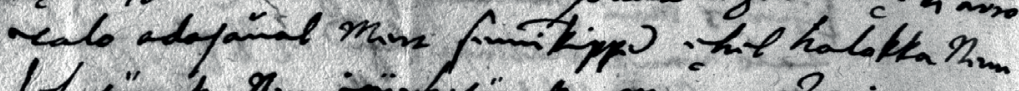

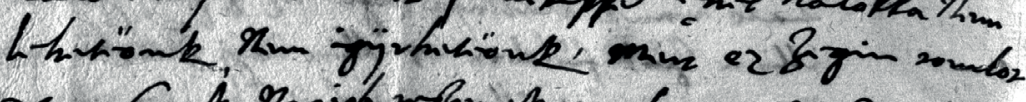

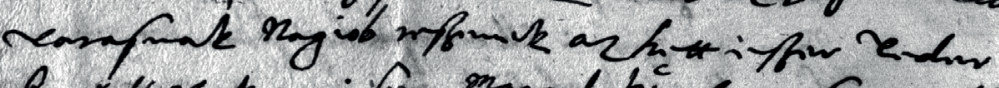

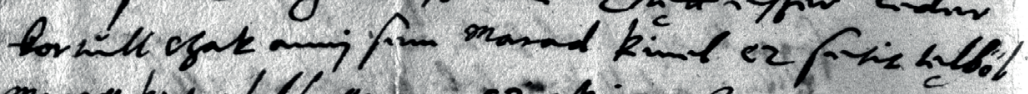

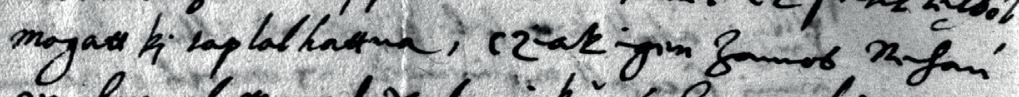

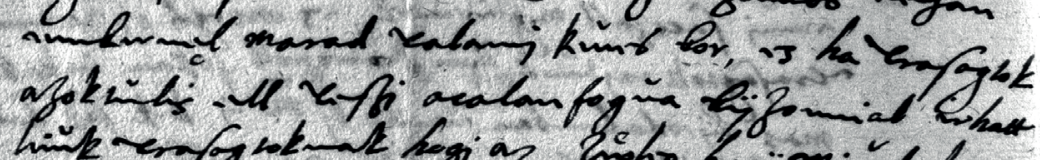

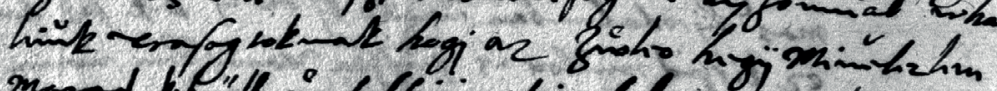

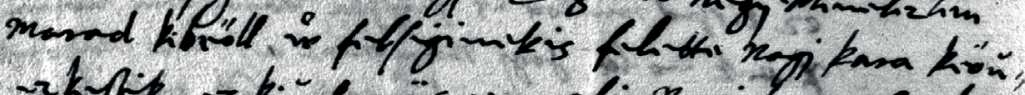

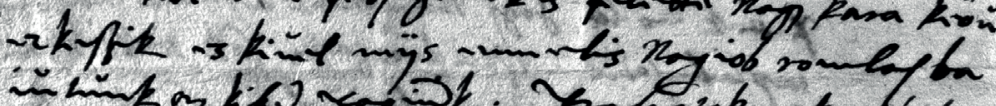

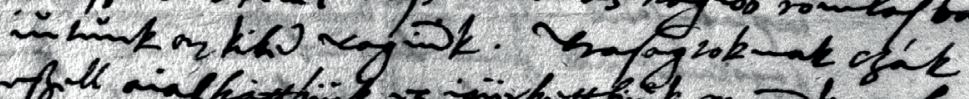

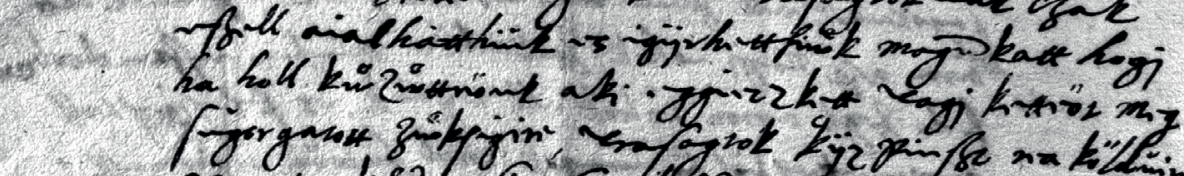

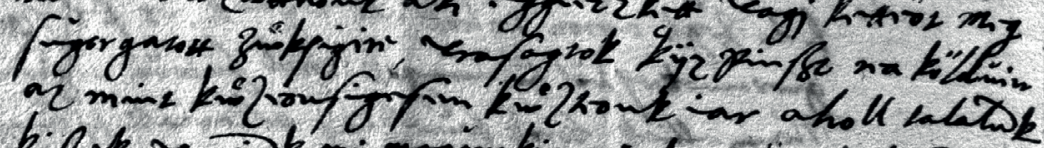

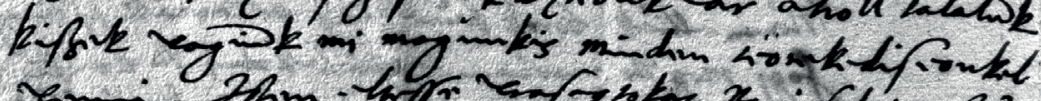

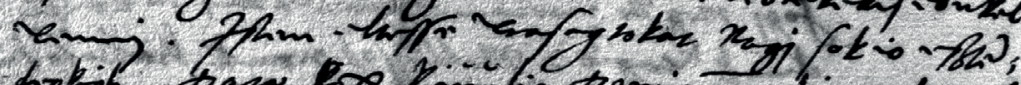

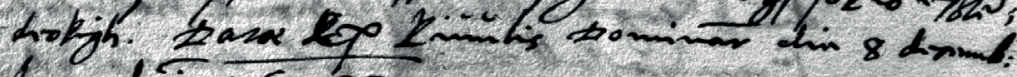
1. 25 is 82 .

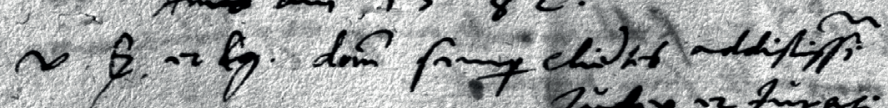

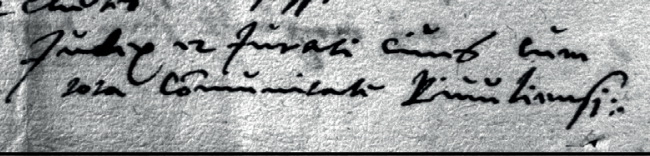


Mert ŭgian soha nem tŭggiŭk hogj ez zegin romlott varason illien Nagj saccz es insigh leött ŭolna eccernęll teobzwe $\mathrm{e}$ kibeol az zeginsig meegh mastis sok kj Nem feselhetett, akkoris iollehett Minthogj kętt iszben attŭnk az ellswe kett oczioban attŭk az masodik zedist peniglen $\stackrel{e}{\mathrm{w}}$ felsige Camoraia azon arron veotte ell az Mint kw̉ e kippen kwّzteonk iart. Aszirt az hatalmas Istenir tis vrasagtokat kiriwk es keöneörgeonk alazatoson egÿz varasŭll vrasagtok minkett az Hętt eszer veder bor felett (ha azt illien kiczin romlott pŭszta varason kj giwteogethetthiwk) Ne banczion az kętt eszer veder bornak vÿonnā azon elęebi arrō valo adasaŭal Mert sēmikippēęhel halokka Nem leheteönk, Nem igÿrheteönk, mert ez zegin romlot varasnak Nagiob reszenek az hętt eszer veder bortŭll ${ }^{4}$ czak annj sem marad kiuel ez setit tęlböl, magatt kj taplalhattna, czak igen zamos Nehan embernęl marad valamj keŭes bor, es ha vrasagtok azoktŭlis ell veszi atalan fogŭa bÿzonnial irhatt hiŭk vrasagtoknak hogj az zwleo hegÿ miŭeletlen marad kibeöll $\stackrel{e}{w}$ felsiginekis felette nagj kara keöŭetkeszik es kiŭel mÿs ennelis Nagiob romlasba iŭtŭnk az kibe vagiūk. vrasagtoknak czak ${ }^{5}$ eszell aialhatthiŭk ${ }^{6}$ es igÿrhetthiwe magūkatt hogj ha holl kwz e̊ sŭgorgatott $z$ i $w$ ksigire, vrasagtok kÿz pinszt rea köldŭin az mint kwّzeonsigesen kỉzteonk iar aholl talalūk kiszek vagiūk mi magŭnkis minden teörekediseonkel vennj. Isten eltesse vrasagtokat Nagj sok io esztedeokigh. Datae $\mathrm{Ex}^{7}$ Riǔŭlis Dominarum die 8 decembris Anno domini 1582.

Venerabilibus Generosissimis et Egregiis dominis semper clientes addittissimi Jŭdex et Jŭrati ciŭes cŭm tota Commŭnitate Riŭŭliensium.

\footnotetext{
${ }^{4} \mathrm{~A} b$ javított betünek látszik (esetleg $t$-böl).

${ }^{5} \mathrm{Az} a$ fölötti vonás feltehetően tévesen kezdett $k$ szára.

${ }^{6}$ A harmadik $a$ fölött szándéktalan tollnyom látszik.

${ }^{7} \mathrm{Az} E$ javított betü, a következő szó $R$ kezdőbetüjéből.
} 

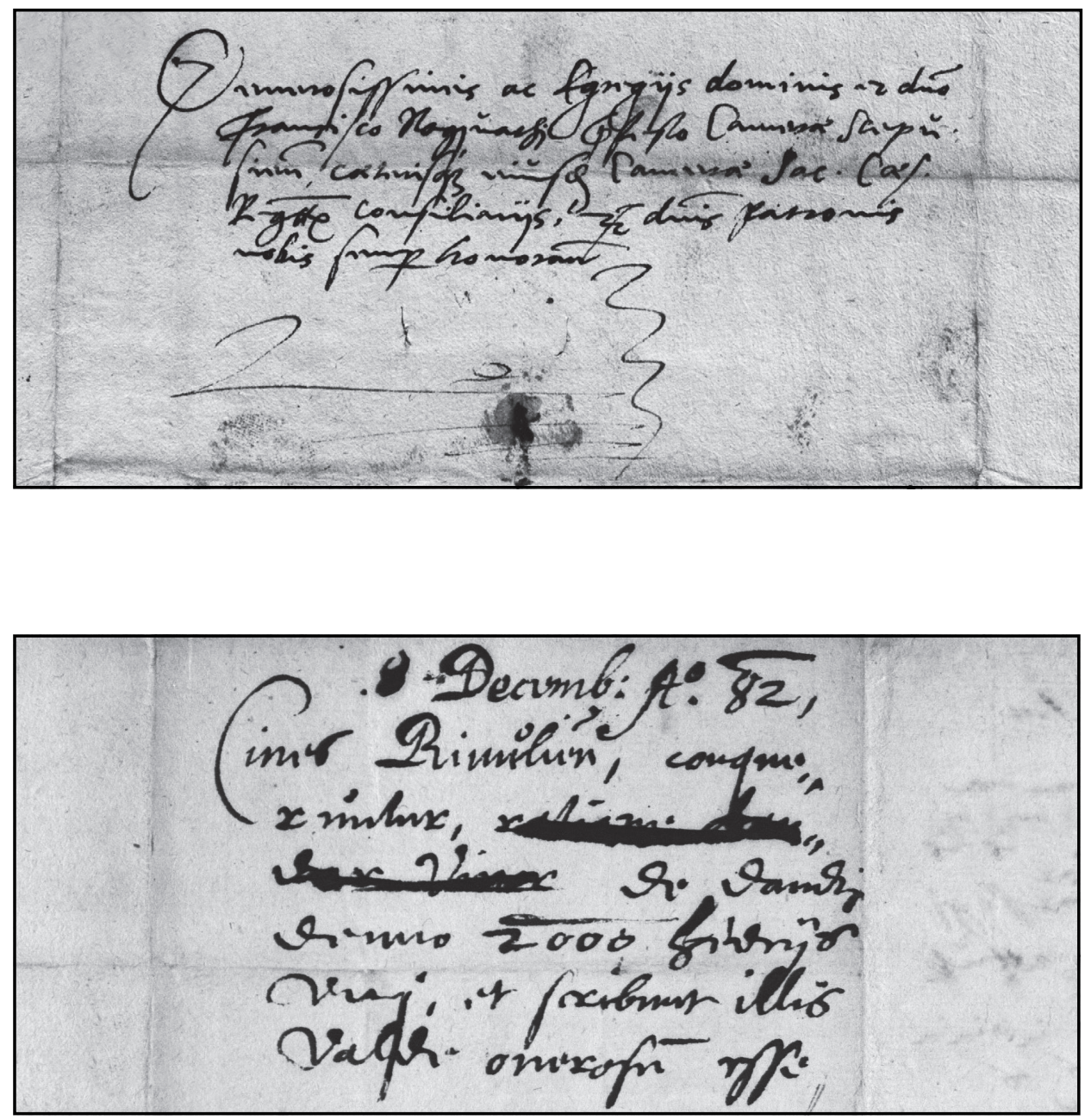
Kivül:

Generosissimis ac Egregÿs dominis et domino

Fransisco Nagjŭathj praefecto Camerae Scepŭ-

siensis, caeterisque eiŭsdem Camerae Sacrae Caesareae

Regietatis consiliarÿs, et dominis patronis

nobis semper honorandis

etc

Más kézzel írva:

8 Decembris Anno 82,

Ciues Rivůlienses, conque-

runtur, $<$ ratione Man-

dar ${ }^{8}$ Vinor $>$ de dandis

denuo 2000 hidrÿs

vinj, et ferebunt illis

Valde onerosum esse

${ }^{8}$ A szó olvasata bizonytalan. 
Varjas, 1584. Varjasi jobbágyok levele.

Varÿas 1584. Ez vÿ Ezt ${ }^{1}[\ldots]$

az mÿ karokat vallottak ${ }^{2}$ az Varÿassiak az teto[...]

hadaktul louagh gialogtol

Tekintetes vitezló Nemes Vraink az mÿnth az Nanassÿ es

Dorogÿ Vrainktul valo Jegzesben ${ }^{3}$ Meg Ertÿ Vrassagod

az Raÿtunk valo szantalan Nÿomorusagokat Merth

Mjnd egÿ hajoban Euezünk azokkal. azert ha mÿnd

azt meg akarnokis Irnÿ az mÿ Rajtunk esset Mind

kar uallast mjnd zÿdalmat. Nem tudnok mÿ azt eló

szamlalnÿ es meg Iratnÿ Hanē Egÿ órók Isten

w'maga tuggia: mjnd az altal Róujdedē somma

szerent az mjt fel Irtunk: Bÿzon̄jal Higgÿe

vrasagod hogi lett fellieb Es Inkab ${ }^{4}$ nagiob boszusagot

kart Es szÿdalmat sohonnat Nem szenuettünk Mjnth

az Magochÿ vrā w Nagsaga ${ }^{5}$ Nepetül, Es az Homonnaj

Giórgÿetül w" Nāgitul: Mert kiualt keppen ha Eǵzer vagÿ ketzer voltāak uolna Raitunk ez eztendóben azt Nem annÿra Nehezlenók: De Jóttón Jóttek Reank Egÿ heten ketzeris Jóttek: Mikor Tizen hat loual Neha .25. loual, Neha .32. loual Neha tóbbel: soha $^{6}$ penig hogi Egi nap vagi ket uoltak uolna Raitunk de harom nap Neǵ nap ótt nap: Mindē nap abrakot ketzer: az kinek arpaia $\mathrm{Ne}$ uolt buzaiat ${ }^{7}$ hortak: vermet bontottak: Annak felette Minde Ebedre ${ }^{8}$ vachorara elegh borth ketzer: Mÿ penig Igen szegenjek vagÿūk hogÿ meg fejünkert sem fizethetünk ${ }^{9}$ az pogannak eleget maradassunkert: Annak felette Hazunkbol az mÿ az szegenÿ embernek agia leple uolna vgj

${ }^{1}$ A $t$ olvasata bizonytalan.

${ }^{2} \mathrm{Az} o$ talán javított betü.

${ }^{3} \mathrm{~A} b$ feltehetően megkezdett $e$-böl van javítva.

${ }^{4} \mathrm{~A} k$ valószínüleg $b$-böl javított betü.

${ }^{5} \mathrm{~A} g$ talán javított betü.

${ }^{6} \mathrm{~A} h$ javított betủ, a javítás során nagybetủ formájú lett.

${ }^{7} \mathrm{~A} t$ más betünek indult.

${ }^{8} \mathrm{~A} b$ javított betü.

${ }^{9} \mathrm{~A} h$ talán javított betü. 


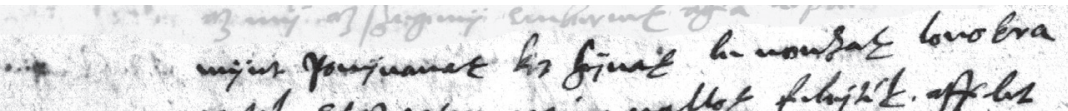

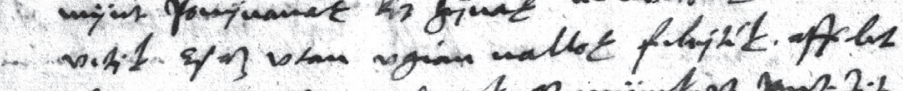

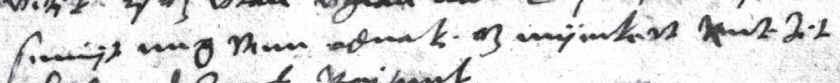

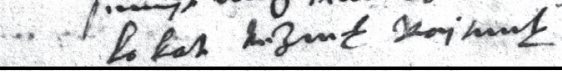

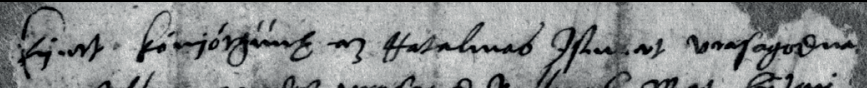

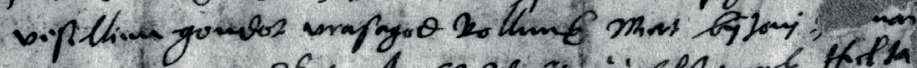

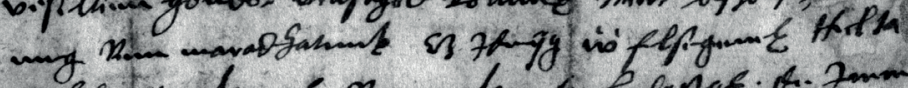

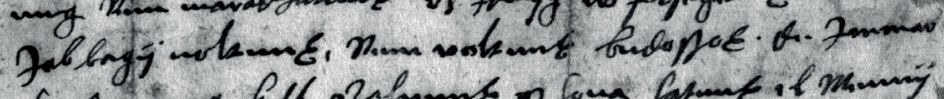

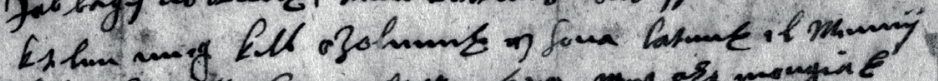

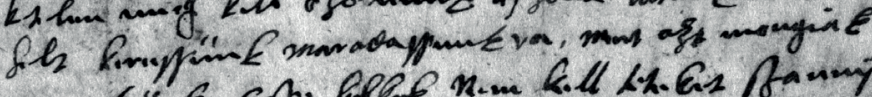

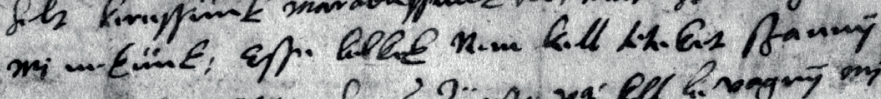

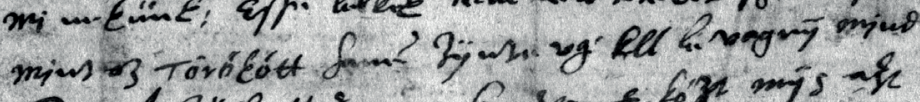

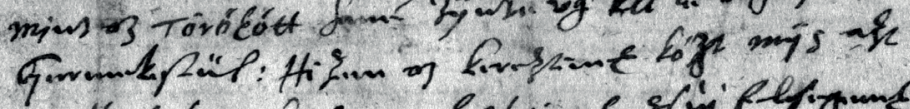

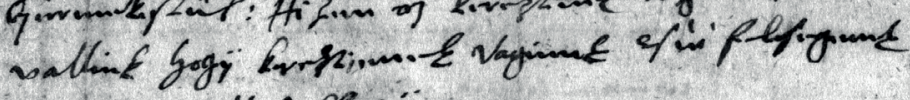
Hawbor Hö́ fobragy

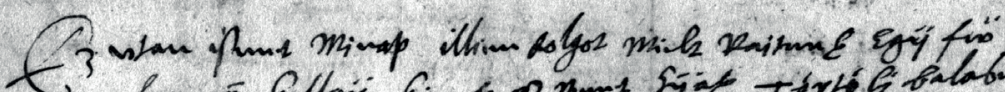

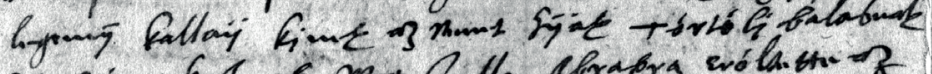

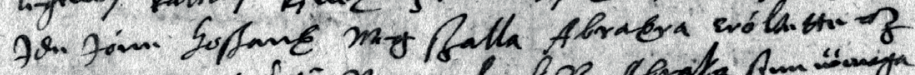

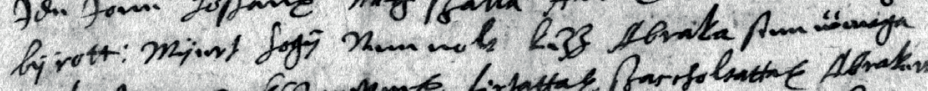

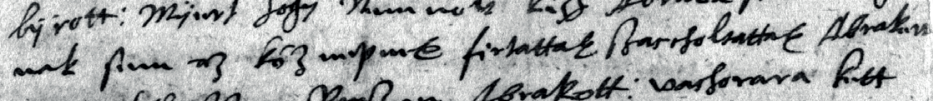

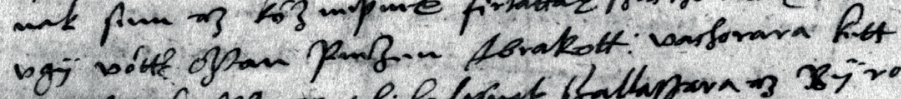

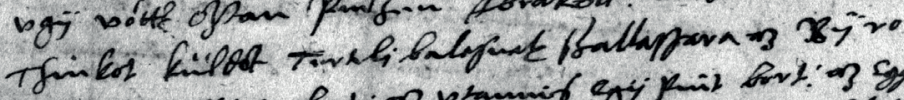

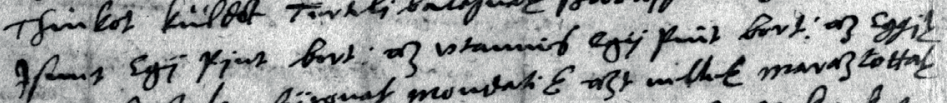

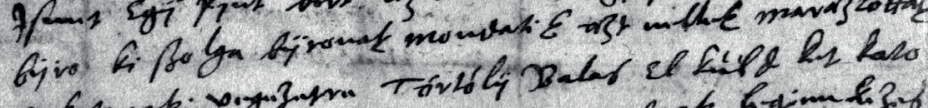

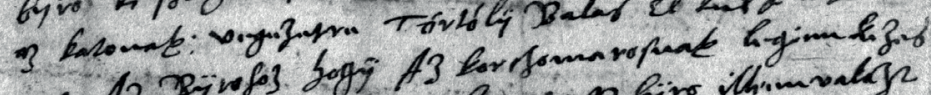

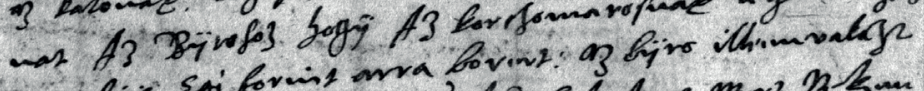

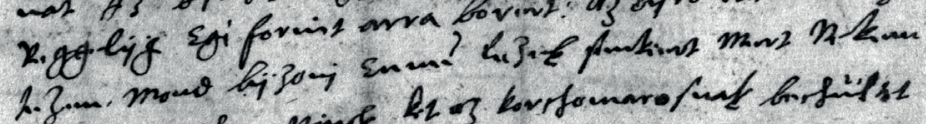

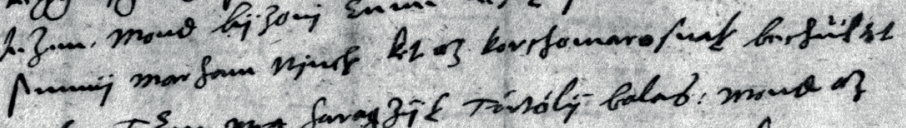

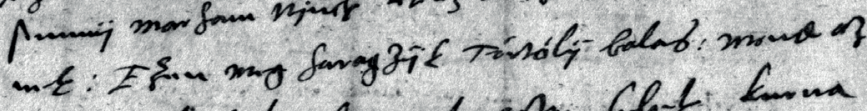

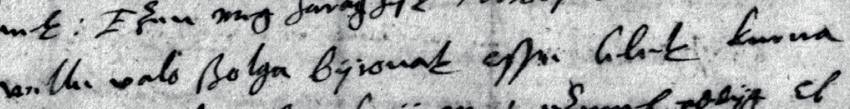

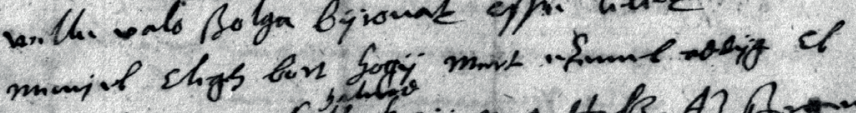

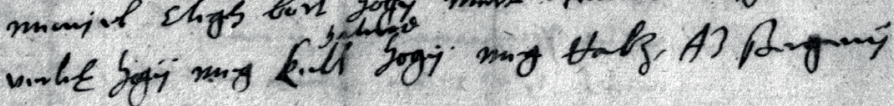


mÿnt ponÿuanak kit hÿnak ${ }^{10}$ le uonzak louokra vetik Es az vtan vgian nallok felejtik. affelet semÿt meg Nem adnak. az mÿenkert Rwt zit kokat teznek Rajtunk

Kjert kónjórgünk az Hatalmas Istenert Vrasagodna[...] vesellien gondot vrasagod Rollunk Mert bÿzonj [...]a[...] meg Nem maradhatunk Ez Ideÿg wँ felsegenek Helta[...] Jobbagÿ uoltunk, Nem voltunk budossok. de Immar ketelen meg kell ozolnunk az houa latunk el Mennÿ helt keressünk maradassunkra, Mert azt mongiak mi nekünk: Esse lelkek Nem kell teteket szannÿ mjnt az Tórókótt hane zÿnte vǵ kell le vagnÿ Mjnd Germekestül: Hizen az kereztenek kőzt ${ }^{11}$ mÿs azt valliuk hogÿ kereztienek Vagiunk es wै felsegenek Jambor Hẅ Jobbagÿ

Ez vtan ismet Minap illien dolgot Mielt Raitunk Egÿ fw' legenÿ kallaÿ kjnek az Neuet hÿak Tórtólj balasnak Ide Jóue hoszank Meg szalla Abrakra Eróltette az bÿrott: Mÿert hogÿ Nem volt kezz Abraka sem w"maga nak sem az kóz nepnek firtattak szaccholtattak Abrakert vgÿ vótth oztan penzen Abrakott: vachorara kett Thiukot küldót Terteli balasnak szallassara az Bÿro Ismet Egÿ pjnt bort: az vtannis egÿ pint bort: az Eggik bÿro ki szolga bÿronak mondatik azt uellek maraztottak az katonak: vegezetre Tórtólÿ Balas El küld ket kato nat Az Bÿrohoz hogÿ Az korchomarosnak legien kezes Reggelÿg Egi forint arra borert: az bÿro illien valazt tezen. mond bÿzonj Enne lezek senkiert Mert Nekem semmÿ marham njnch kit az korchomarosnak bechültet nek: Ezen meg haragzÿk Tórtólÿ balas: mond az velle valo szolga bÿronak esse lelek kurua menjel Elegh bort hogÿ mert ezennel addÿg El verlek hogÿ meg kell halnod ${ }^{12}$ hogÿ meg Halz, Az szegenÿ

\footnotetext{
${ }^{10} \mathrm{~A} h$ valószínüleg javított betü.

${ }^{11} \mathrm{~A} z$ javított betü.

${ }^{12}$ A szó interlineáris betoldás.
} 


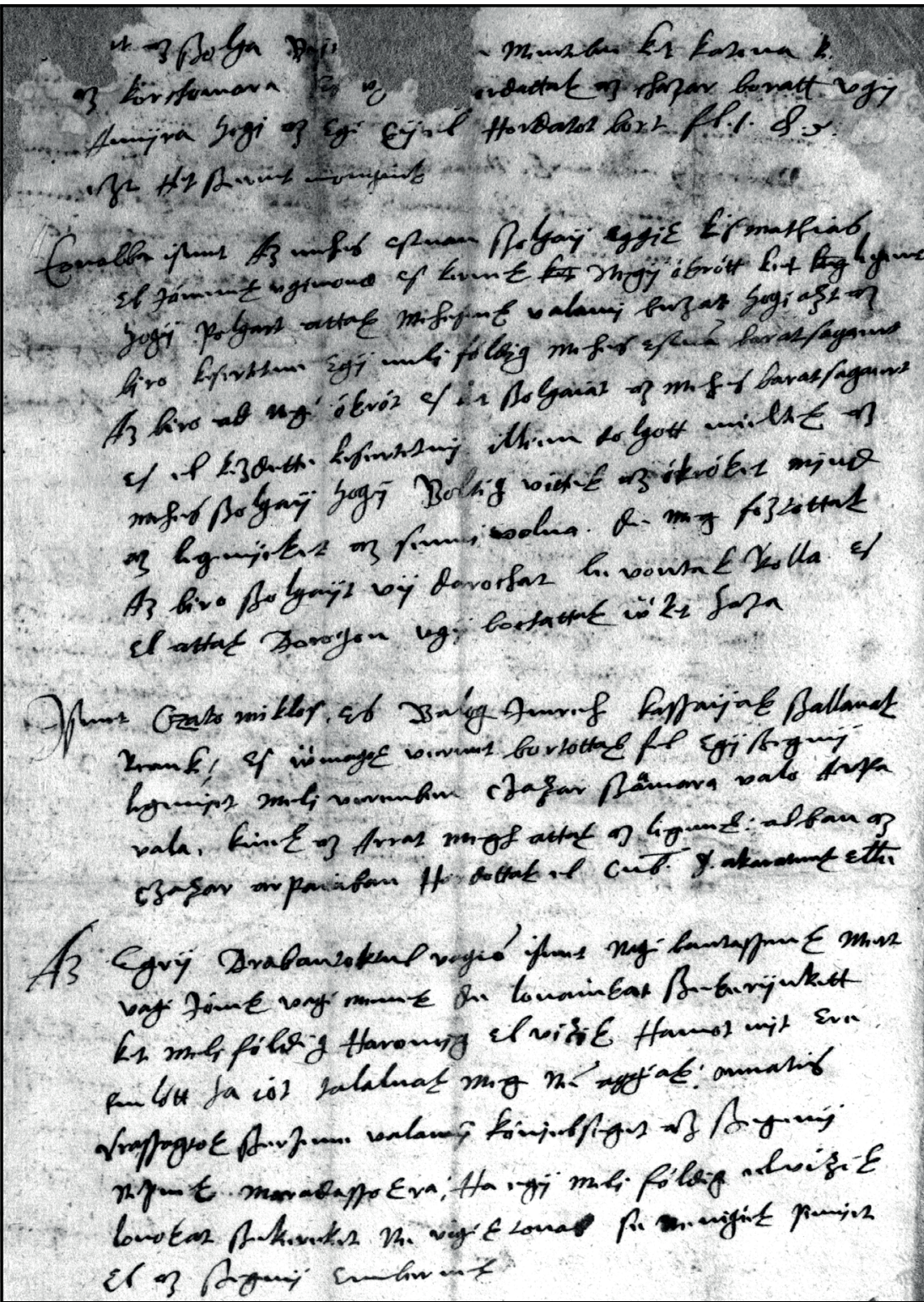


[...]rt az szolga Bÿr[...] Menteben ket katona $\mathrm{k}[\ldots]$

az korchomara Es v[...] [...] ordattak az chazar boratt vgÿ

Annÿra hogi az Egi Eÿel Hordatot bort florenorum 1. denariorum 5:

ezt Hit szerent mongiuk

Touabba ismet Az mehes estuan szolgaÿ eggik kis mathias

El Jóuenek vgimond es kernek $<$ ket $>$ Negÿ ókrótt ket $<$ keg $>$ legent

hogÿ polgart attak mehesnek valamj buzat hogi azt az

bjro kesertetne Egÿ meli fóldig mehes Estuā baratsagaert

Az biro ad neǵ ókrót es ket szolgaiat az mehes baratsagaert

Es el kezdette kesertetnÿ illien dolgott mieltek az

mehes szolgaÿ hogÿ Boltig vittek az ókróket mjnd

az legenÿeket az semi volna. de meg foztottak

Az biro szolgaÿt vÿ darochat le vontak Rolla Es

El attak Dorogon vgÿ bochattak wket haza

Ismet Czato miklos. Es Balog Imreh kassaÿak szallanak

Reank: Es w"magok vermet bortottak fel Egÿ szegenÿ

legenjet melj veremben czazar szaamara ${ }^{13}$ valo Arpa

vala. kinek az Arrat megh attak az legennek: abban az

czazar arpaiaban Hordottak el Cubulos 8. akaratunk elle

Az Egrÿ Drabantoktul vagio ismet Nagi bantassunk Mert

vagi Jónek vagi menek de louainkat szekerÿnkett

ket melj fóldig Haromig El vizik Hamot mjt Ere

. $\mathrm{m}^{14}$ lótt ha iot talalnak meg ne aggiak: onnatis

Vrassagtok szerzene valamÿ kónjebseget az szegenÿ

nepnek maradassokra: Ha egÿ Meli fóldig elvizik

louokat szekereket Ne vigek touab se ne uigiek semiet

El az szegenÿ Embernek

${ }^{13}$ A második $a$ interlineáris betoldás.

${ }^{14} \mathrm{Az}$ olvasat bizonytalan. 
E 254 - 1585. jan. No. 2.

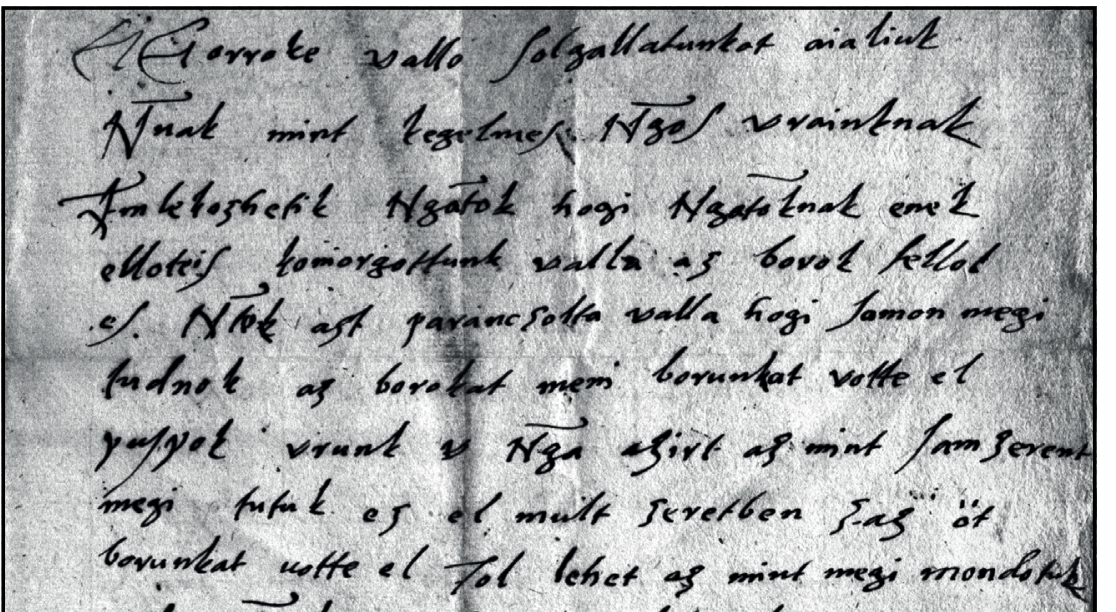

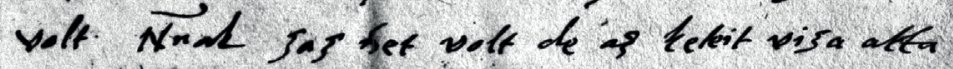
velt wis tand pening tijtan sol wolk

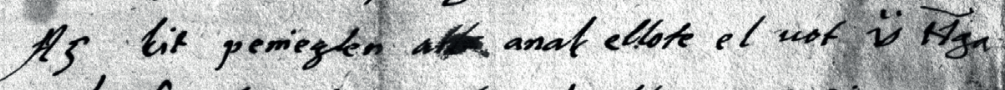

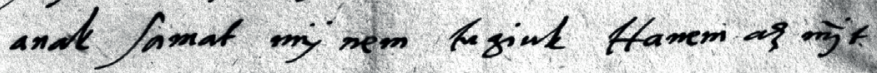

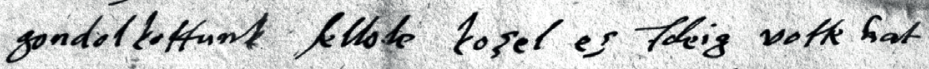

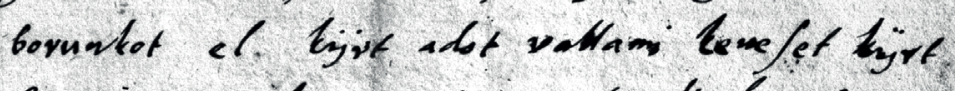
Semit mom adot of mint of tauali bisecs. megi mutritin mere tauds of fog horde bovra adot kavom jag fovintet es stkndoben periglen

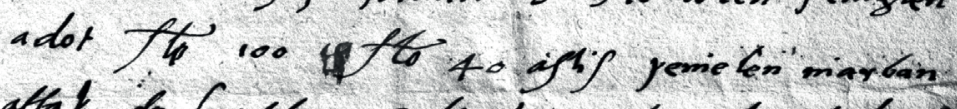

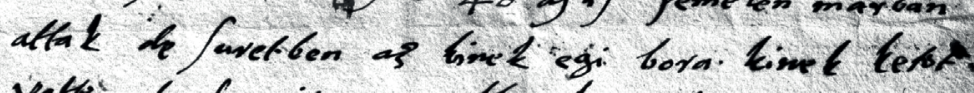

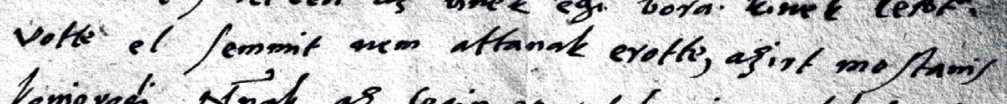

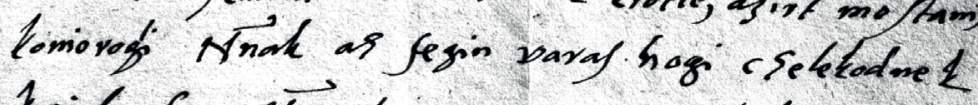
Tesielimefon Ngatokates fegin varalsat bit orro be

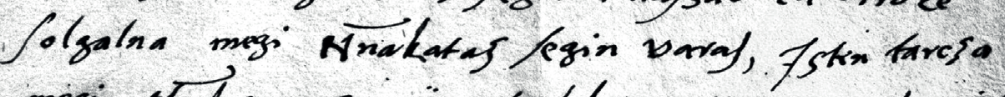
megi tratat as ve eflewdoben, $D$ atum eX opida

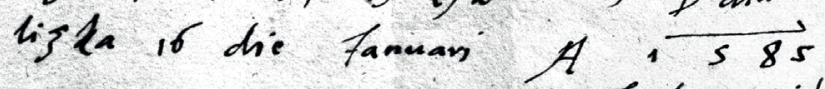

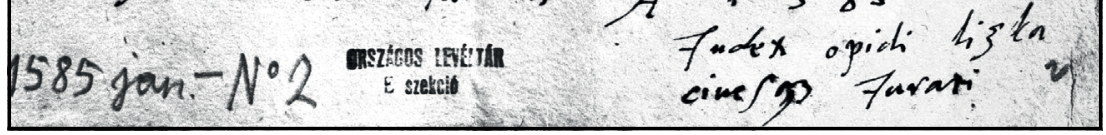

122 
I.21.

Olaszliszka, 1585. jan. 16. olaszliszkai jobbágyok levele.

EEorroke vallo solgallatunkot aialiuk $\bar{N}$ nak mint kegelmes $\bar{N}$ gos vrainknak

Emlekozhetik $\bar{N}$ gatok hogi $\bar{N}$ gatoknak enek elloteis koniorgottunk valla az borok fellol ${ }^{1}$ es. Ntok azt paranczolta valla hogi samon megi tudnok az borokat meni borunkat votte el puspok vrunk $\ddot{v} \bar{N} g a$ azirt az mint sam zerent megi tutuk ez el mult zeretben zaz öt borunkat uotte el Jol lehet az mint megi mondotuk volt N $\bar{n}$ ak zaz het volt de az keteit viza atta volt az tauali penieg tiztan zaz volt Az kit penieglen $<$ all. $>$ anak ellote el uot $\ddot{\mathrm{v}} \overline{\mathrm{N}} g \mathrm{a}$ anak samat mÿ nem tugiuk Hanem az m $\bar{y} t$ gondolkottunk fellole kozel ez Ideig votte hat borunkot el kÿrt adot vallami keueset kÿrt semit nem adot az mint az tauali fizetese megi mutatia mert tauali az $\mathrm{zaz}^{2}$ hordo borra ${ }^{3}$ adot harom zaz forintot ez eztendoben peniglen adot florenos $100<$.. > florenos 40 astis penielen niarban attak de suretben az kinek egi bora. kinek ketot. votte el semmit nem attanak erotte, azirt mostanis koniorogi ${ }^{4} \bar{N}$ nak az segin varas hogi czelekodnek kegielmesson $\bar{N}$ gatokat az segin varassal kit orroke solgalna megi Nnakat az segin varas, Isten tarcza megi Nakat az vÿ estendoben, Datum ex opido lizka 16 die Januari Anno 1585

Judex opidi lizka civesque Jurati

\footnotetext{
${ }^{1} \mathrm{Az}$ utolsó $l$ más betünek indult.

${ }^{2} \mathrm{Az}$ első $z$ hosszú szárú $s$-ből javított betü.

${ }^{3}$ A második $r$ talán megkezdett $a$-ból lett javítva.

${ }^{4} \mathrm{~A} g$ után téves betükezdemény.
} 


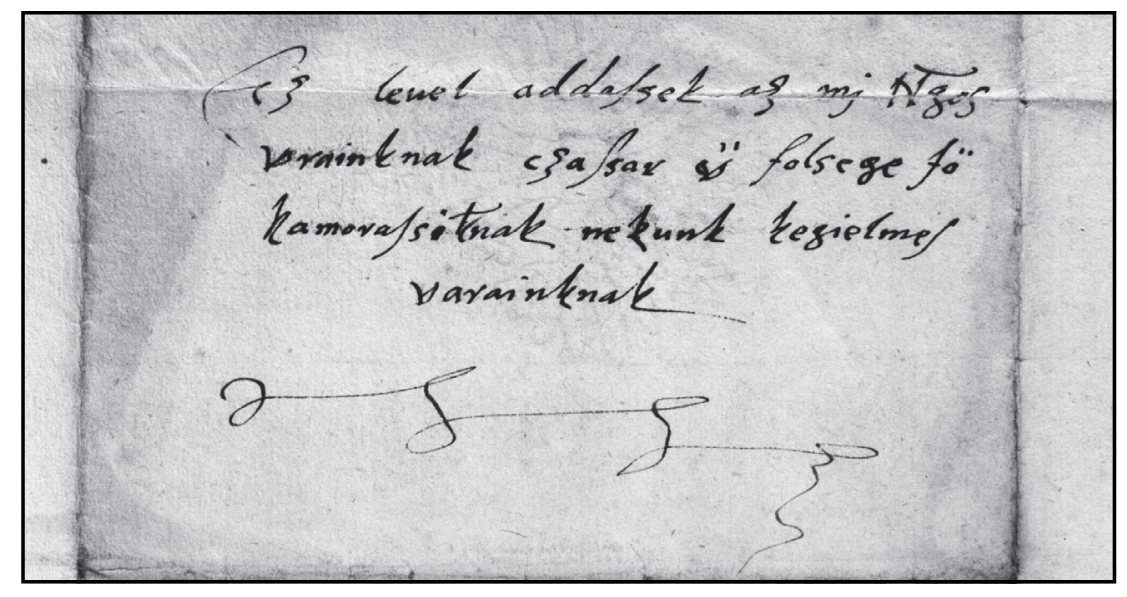

1585 
Kivül:

Ez leuel addassek az mj Ngos

vrainknak czassar $\ddot{v}$ folsege fö

kamorassiknak ${ }^{5}$ nekunk kegielmes

varainknak

etc

1585

${ }^{5}$ Az $i$ javításnak tünik; az $i$-ből indulva nazálist jelző rövidítés látszik. 


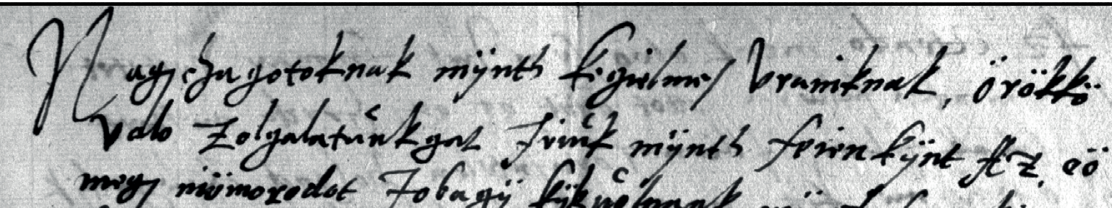

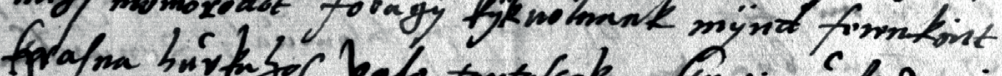

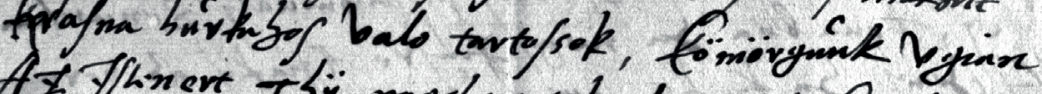

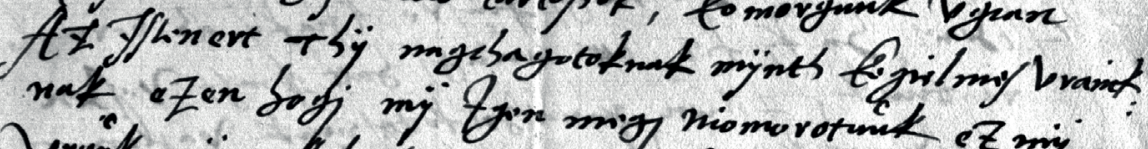

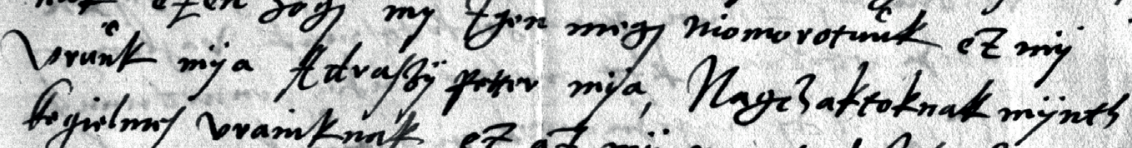

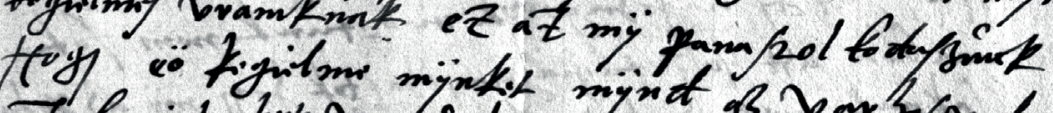

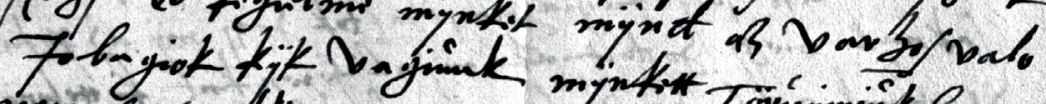

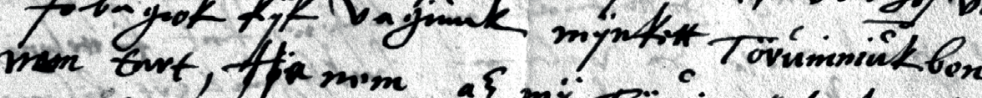

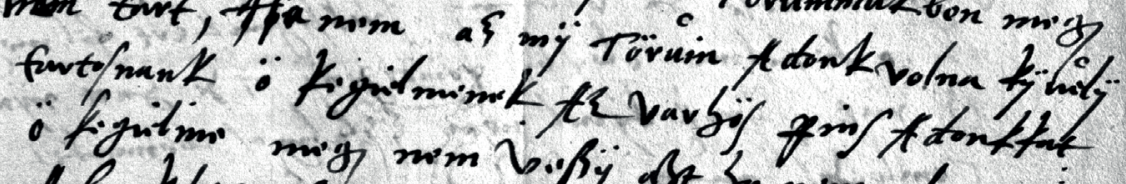

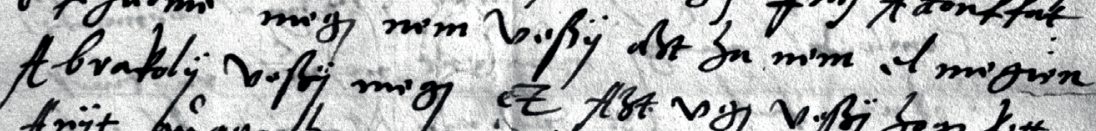

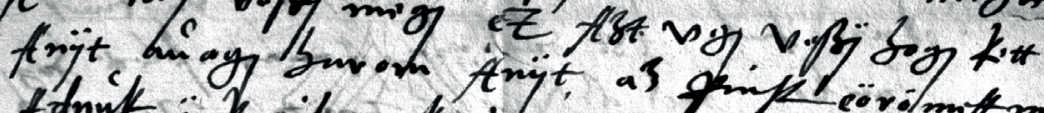

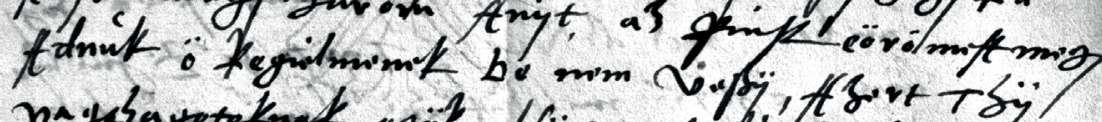

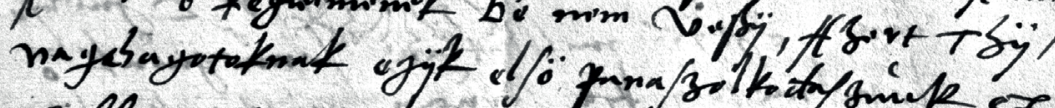

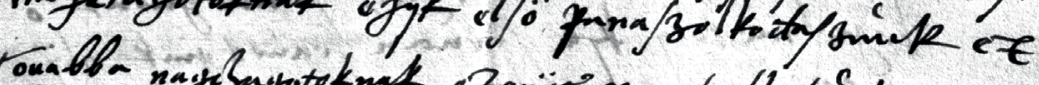

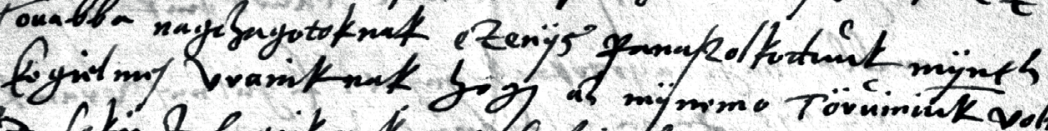

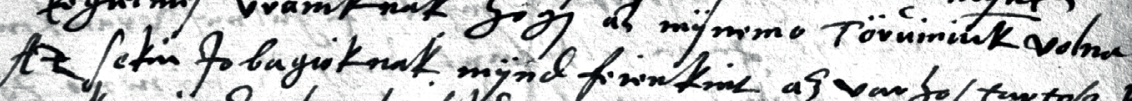

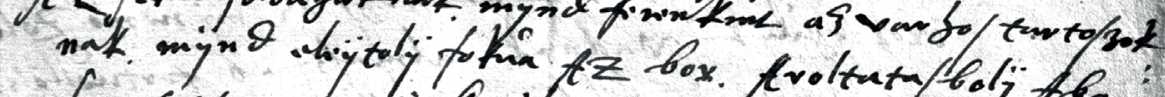

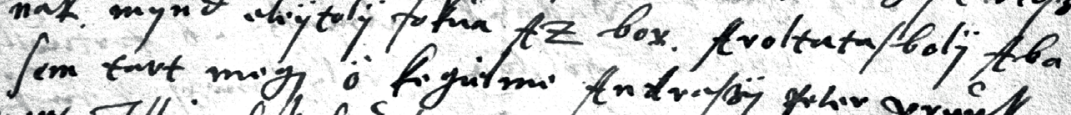

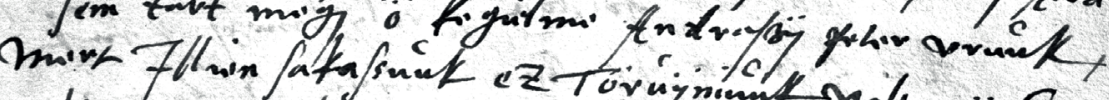
Hog eztinatiok jovomfor foranak

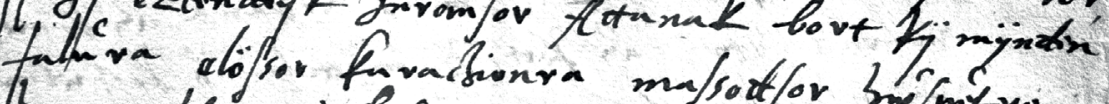

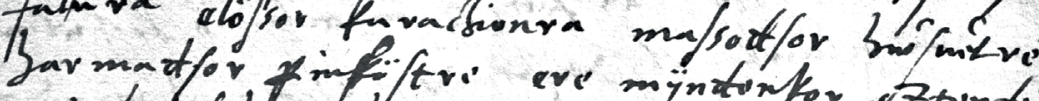

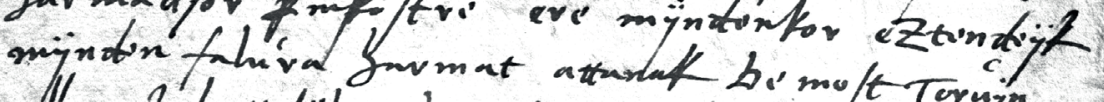
ellore is.higiotik is

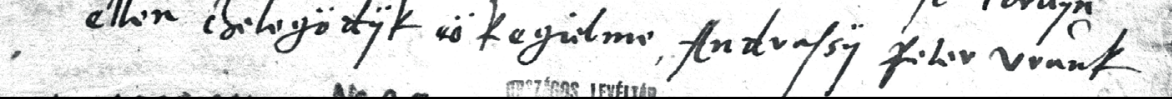


Krasznahorka, 1585. VI. 5. Krasznahorkai jobbágyok levele.

Nagjchagotoknak mÿnth kegielmes Vrainknak, örökkö valo Zolgalatŭnkgat Iriŭk mÿnth feienkÿnt Az eö megj niömorodot Jobagÿ kÿk ŭolnank mÿnd feienkint ${ }^{1}$ krasna $^{2}$ hŭrkahos valo tartossok, köniörgŭnk vgian Az Istenert Thÿ nagchagotoknak mÿnth kegielmes vrainknak ezen hogj mÿ Igen megj niomorotŭnk ez mÿ Vrŭnk mÿa Adraszÿ petter mÿa, Nagczaktoknak mÿnth kegielmes vrainknak ez az mÿ panaszolkodaszŭnk Hogj eö kegielme mÿnket mÿnd az Varhos valo Jobagiok kÿk vagiŭnk mÿnkett Törŭinniŭkben megj nem ${ }^{3}$ tart, $\mathrm{Ha}^{4}$ nem az mÿ Törŭin Adonk volna kÿŭelÿ tartosnank ö kegielmenek. Az Varhös pins Adonkkat ö kegielme megj nem veszÿ azt ha nem el megien Abrakolÿ veszÿ megj ez Azt vgj veszÿ hogj kett Anÿt aŭagj harom Anÿt, az pinst eörömest megj Adnŭk ö kegielmenek De nem veszÿ, Azert Thÿ nagchagotoknak egÿk elsö panaszolkodaszŭnk ez

Touabba nagczagotoknak ezenÿs panaszolkodŭnk mÿnth kegielmes vrainknak hogj az mÿnemo Törŭiniūk volna Az sekin Jobagioknak mÿnd feienkint az varhos tartoszoknak. mÿnd eleÿtolÿ fokŭa Az bor. Aroltatasbolÿ Aba sem tart megj ö kegielme Andraszÿ Peter vrŭnk, mert Illien sakassŭnk ez Törŭÿniŭnk volt mÿndenkor, Hogj eztendeÿk haromsor Adanak bort kÿ mÿnden falŭra elössor karaczionra massodsor hw̌sǔetre

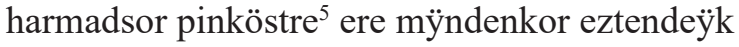
mÿnden falŭra harmat attanak De most Torŭÿn ellen czelegödÿk eö kegielme, Andrassÿ Peter vrŭnk

${ }^{1} \mathrm{Az} i$ sajátos jellege miatt a facsimilében az olvasó hajlamos $o$-t látni.

${ }^{2}$ A $k$ javított betü; az $r$ a-ból van javítva.

${ }^{3} \mathrm{Az}$ e javított betü.

${ }^{4}$ A szó javított, a helyén Tör állt.

${ }^{5} \mathrm{~A} k$ talán $f$-ből javított betü. 


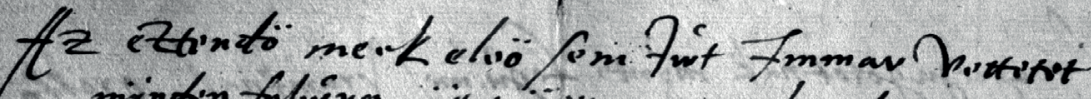

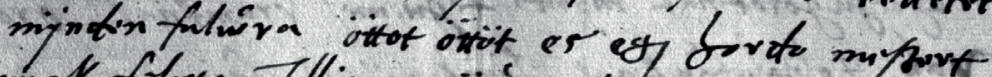

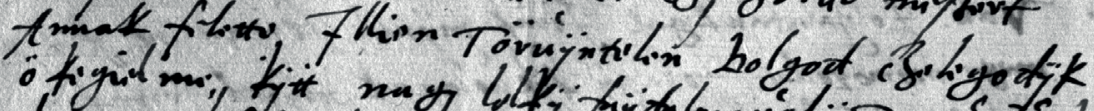

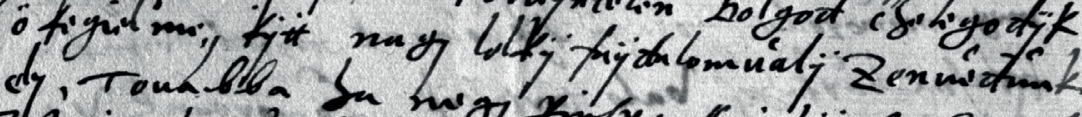

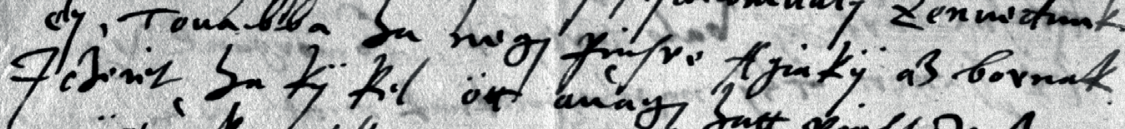

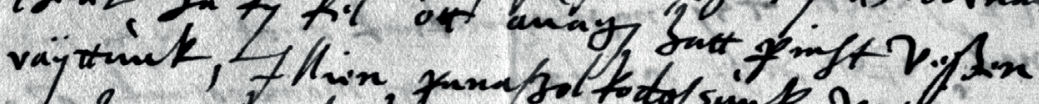

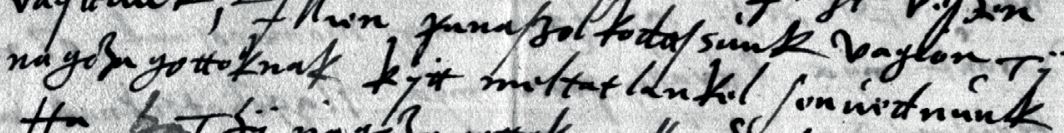

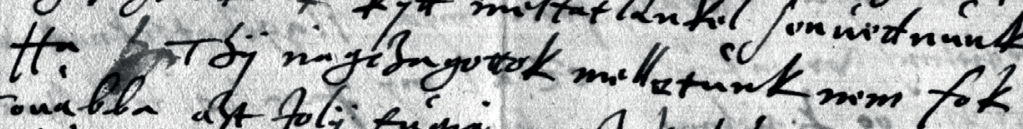

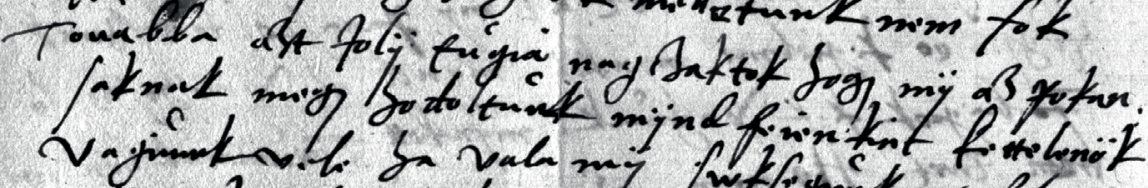

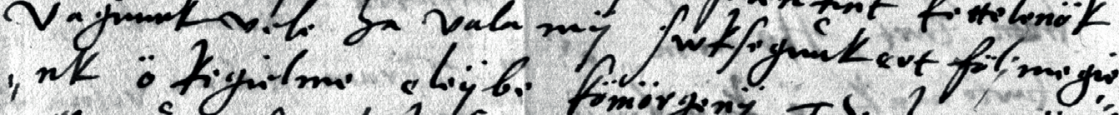

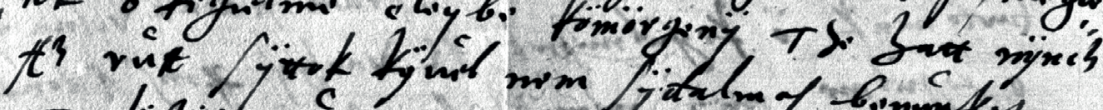

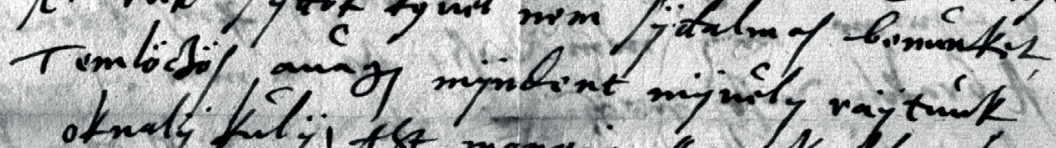

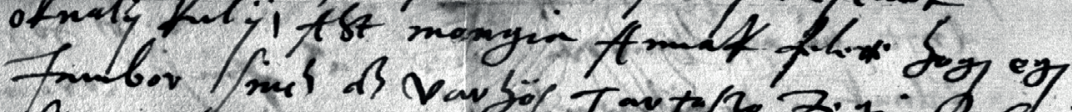

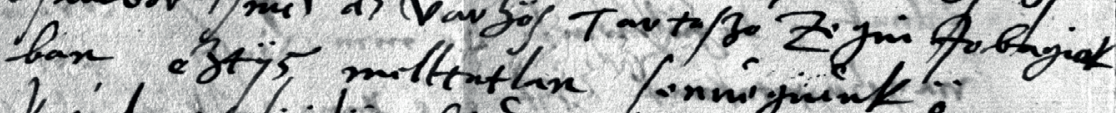

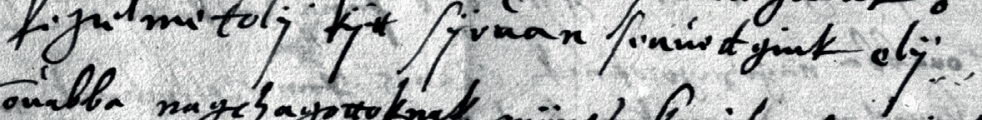

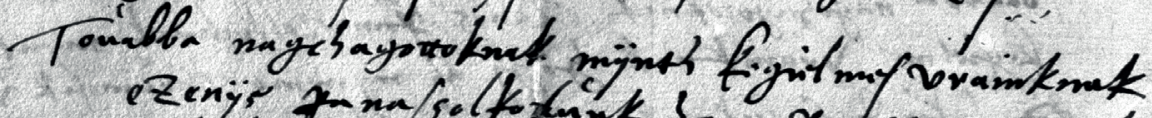

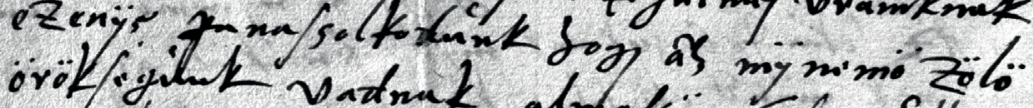

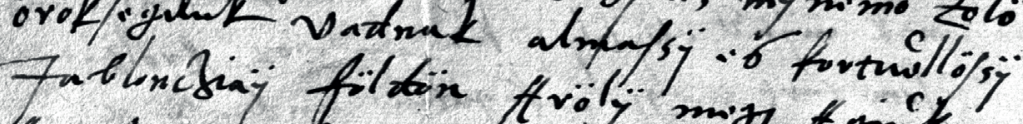
tz b.ymen Formsen mins as tomek

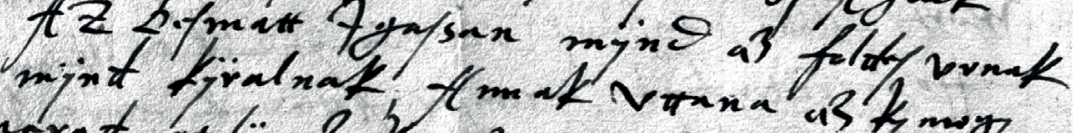

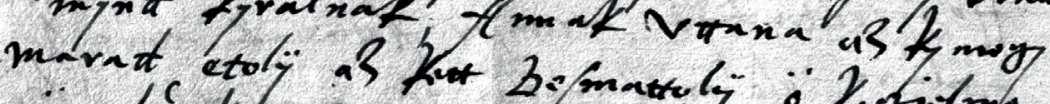

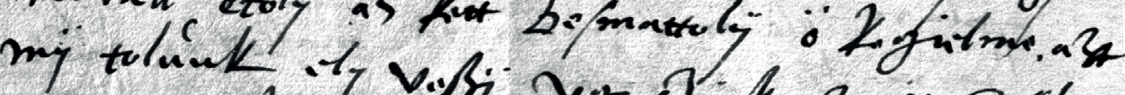

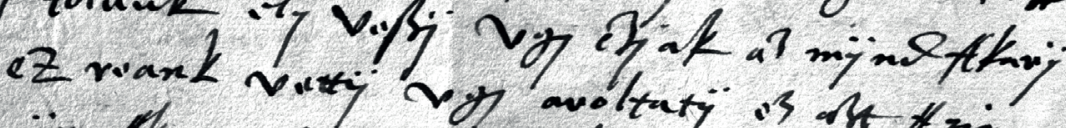

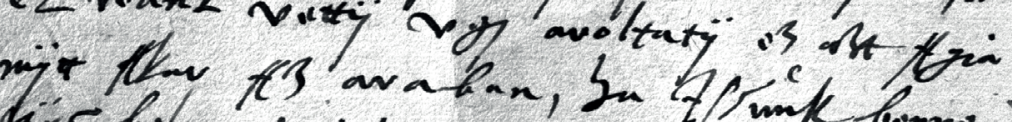

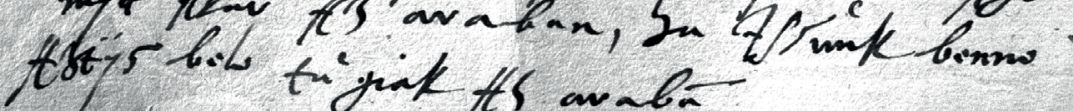


Az eztendö meek eleö sem Jw̆t Immar vettetet mÿnden falw̌ra öttot öttöt es egj hordo meszert Annak felette Illien Törŭÿntelen Dolgod czelegodÿk ö kegielme, ${ }^{6}$ kÿtt nagj lelkÿ faÿdalomŭalÿ Zenŭedŭnk ely, Touabba ha negj pinsre Agiakÿ az bornak Iczeiet ha kÿ kel ött aŭagj hatt pinst veszen raÿttŭnk, Illien panaszolkodassŭnk vagion Tÿ nagczagottoknak kÿtt meltatlan kel senŭednŭnk Ha $<. .>^{7}$ Thÿ nagczagottok melletŭnk ${ }^{8}$ nem fok

Toŭabba azt Jolÿ tŭgia nagczaktok hogj mÿ az pokansaknak megj hodoltŭnk mÿnd feienkint kettelenök vagiŭnk vele ha vala mÿ swksegŭnkert följ megio-nk ö kegielme eleÿbe köniörgenÿ The hatt nÿnch Az rŭt ${ }^{9}$ sÿttok kÿŭel nem sÿdalmas benŭnket, Temlöczös aŭagj mÿndent mÿŭely raÿtŭnk, oknalÿ kŭlÿ, Azt mongia Annak felette hogj egj Jambor sinch az varhös Tartaszo Zegin Jobagiok ban eztÿs melltatlan senŭegiŭnk ö kegielmetolÿ kÿtt sÿrŭan ${ }^{10}$ senŭedgiuk elÿ.

Toŭabba nagchagottoknak mÿnth kegielmes vrainknak ezenÿs panassolkodŭnk hogj az mÿnemö Zölö öröksegŭnk vadnak almassÿ es kortŭollössÿ Jabloncziaÿ földön Arölÿ megj Agiŭk Az Desmatt Igassan mÿnd az foldes vrnak mÿnd kÿralnak, Annak vttana az kj megj marad etolÿ az kett Desmattolÿ ö kegielme. azt mÿ tolŭnk ely veszÿ vgj czjak az mÿnd Akarÿ ez reank vettÿ vgj aroltatÿ ez azt Agia mÿtt Akar Az araban, ha Iszŭnk benne Aztÿs bele tŭgiak Az arabā

\footnotetext{
${ }^{6}$ A vessző utáni vonás szándéktalannak látszik.

${ }^{7}$ A törölt betüegyüttes esetleg $k y$ lehetett.

${ }^{8}$ A második $e$ javított betü.

${ }^{9}$ A $t$ javított betü.

${ }^{10} \mathrm{Az} \breve{u} a$-ból van javítva.
} 


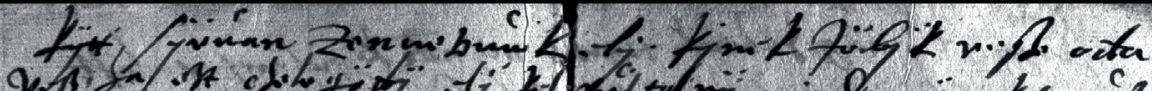

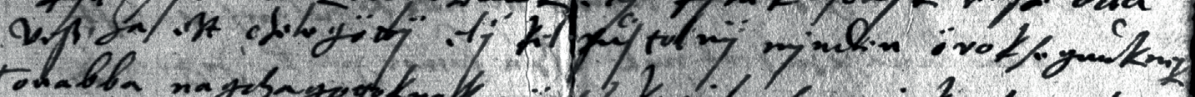

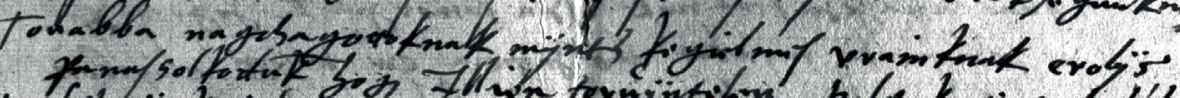

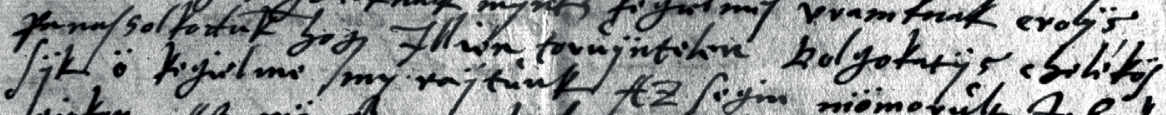

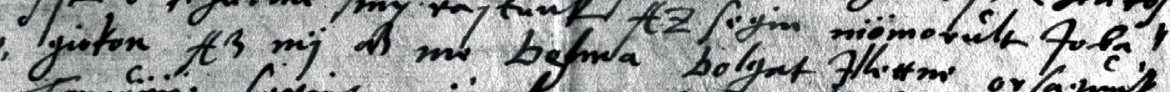

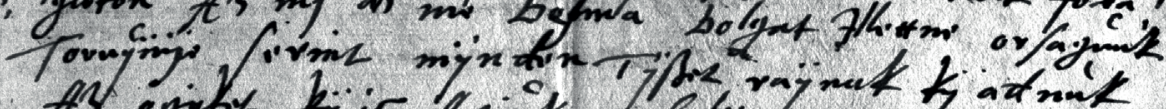

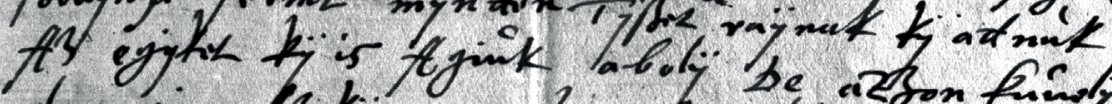

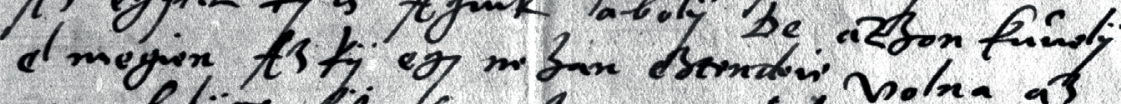

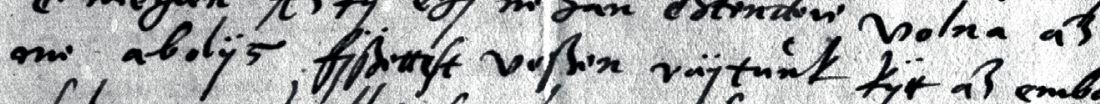

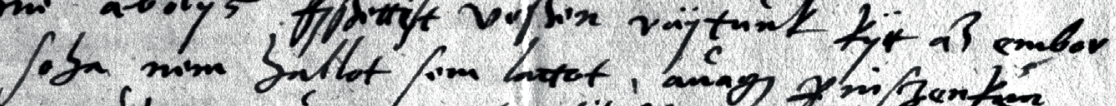
vannikis, ming ov

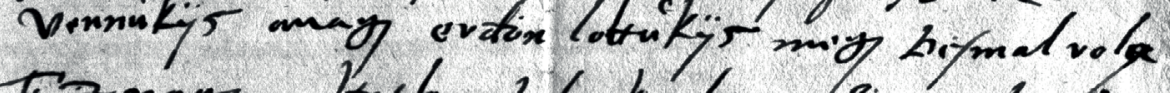

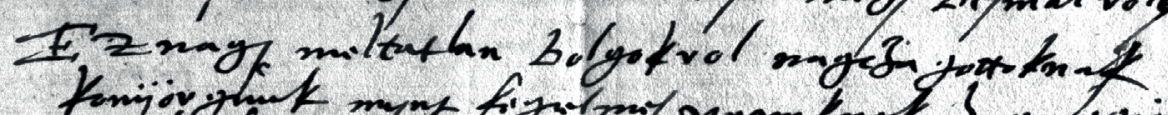

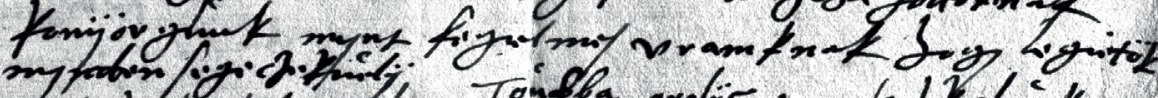

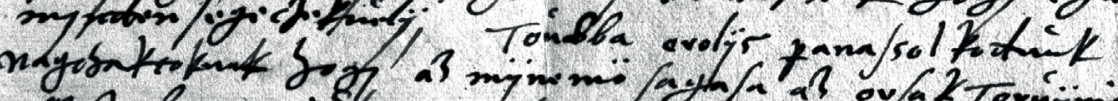

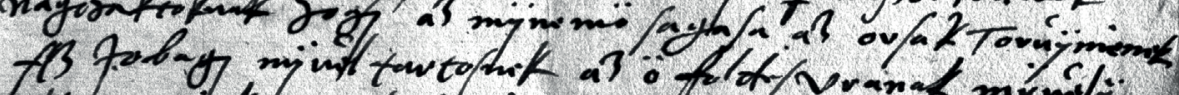

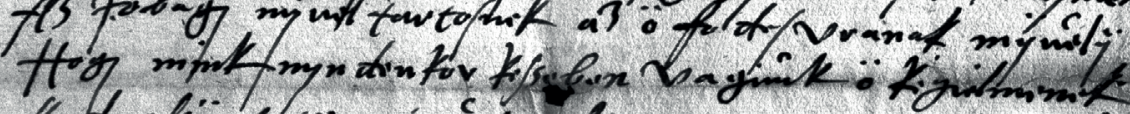

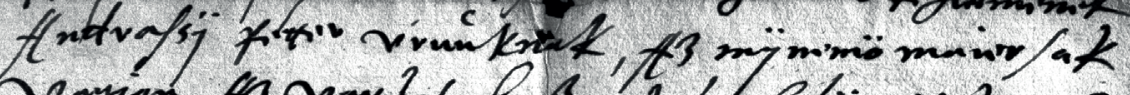

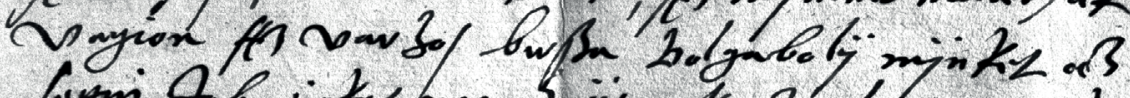

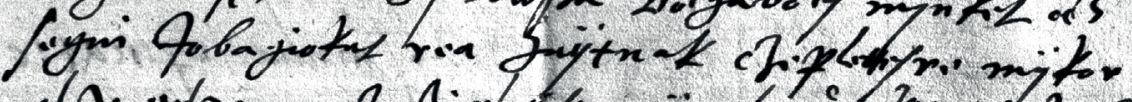

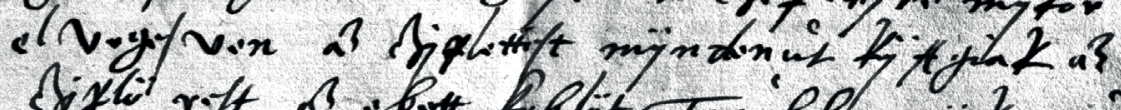

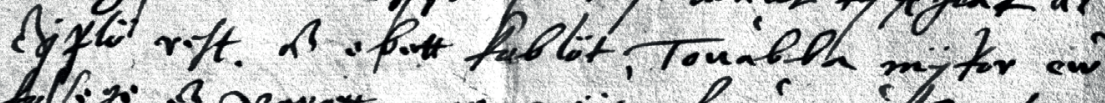
fligi: a vover mos aviato

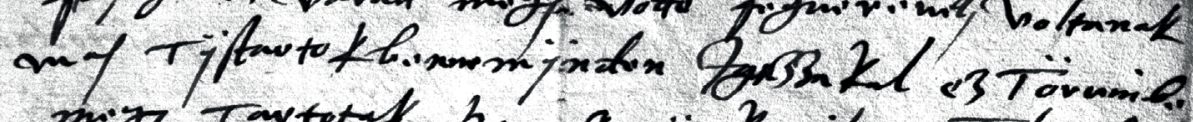

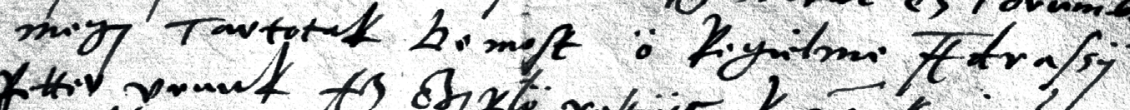

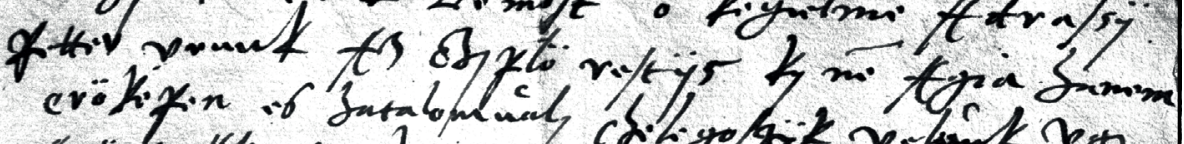

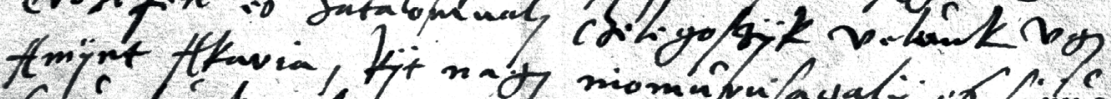

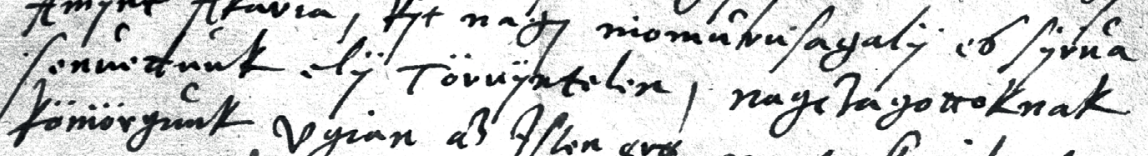

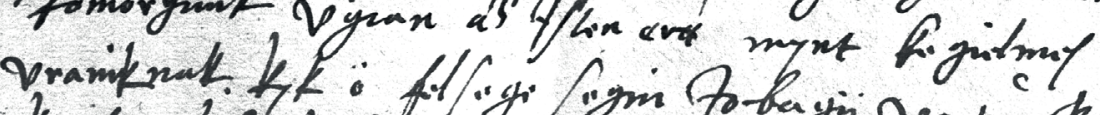

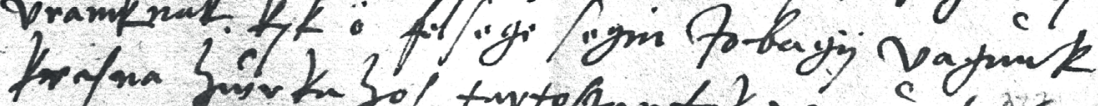

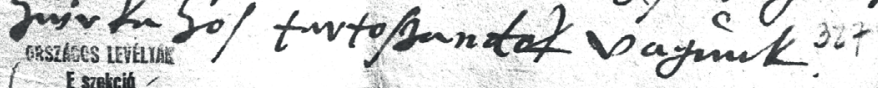


kÿtt sÿrŭan zenuedŭnk elÿ kjnek Jöbÿk resze oda vesz, ha ezt chelegödÿ elÿ kel pŭstolnÿ mjnden öroksegŭnknek

Touabba nagchagottoknak mÿnth kegielmes vrainknak erolÿs ${ }^{11}$ panassolkodūk hogj Illien torŭÿntelen Dolgokatÿs chelekös-sÿk ö kegielme my raÿtŭnk Az segin niömorŭlt Joba-giokon Az mÿ az me Desma ${ }^{12}$ Dolgat Illettne orsagŭnk Torŭÿnÿe serint mÿnden Tÿszet raÿnak kÿ adnŭk Az egÿket kÿ is Agiŭk abolÿ De azzon kuŭolÿ el megien Az kÿ egj nehan eztendoie volna az oue abolÿs fÿszettest veszen raÿtŭnk kÿtt az embor soha nem hallott sem lattot, aŭagj pinszenkŭn vennŭkÿs aŭagj erdön löltŭkÿs megj Desmal rola ${ }^{13}$

Ez nagj meltatlan Dolgokrol nagczagottoknak ${ }^{14}$ konÿörgŭnk mynt kegielmes vrainknak hogj legietök mynden segeczekŭelÿ, Toŭabba erolÿs panassolkodŭnk nagchaktoknak hogj az mÿnemö sagasa az orsak Torŭÿnienek Az Jobagj mÿŭel tartosnek az ö foldesvranak mÿŭelÿ Hogj mink mjndenkor kesseben vagiŭnk ö kegielmenek Andrassÿ petter vrŭnknak, Az mÿnemö maiorsak vagion $\mathrm{Az}$ varhos bwsza Dolgabolÿ mÿnket az segin Jobagiokat rea haÿtnak czeplettesre mÿkor el vegesven az czjplettest mÿndenŭt kÿ Agiak az czjplö rest. az ebett koblöt, Toŭabba mÿkor ew folsege ez varatt megj vötte fegŭereŭel, voltanak mas Tÿstartok benne mÿnden Igazzakal ez Töruinbe megj Tartotak De most ö kegielme Âdrassÿ Petter vrunk Az czjplö restÿs ky nē Agia hanem erökepen es hatalomŭalj chelegoszÿk velŭnk ${ }^{15}$ vgj Amÿnt Akaria, kÿt nagj niomŭrusagalÿ es sÿrŭa senŭedŭnk elÿ Töruÿntelen, nagczagottoknak köniörgŭnk vgian az Isten ertt myntt kegielmes vrainknak. kyk ö felsege segin Jobagÿ vagŭnk krasna ${ }^{16}$ hw̆rkahos tartoszandok vagŭnk.

\footnotetext{
${ }^{11}$ A szó utáni vonás szándéktalannak látszik.

${ }^{12}$ A Des feltehetően Dol-nak indult.

${ }^{13} \mathrm{Az}$ a javított betü.

${ }^{14}$ A második $k$ javított betünek látszik.

${ }^{15} \mathrm{Az} \breve{u}$ javított betü.

${ }^{16} \mathrm{Az} r$ javított betü.
} 

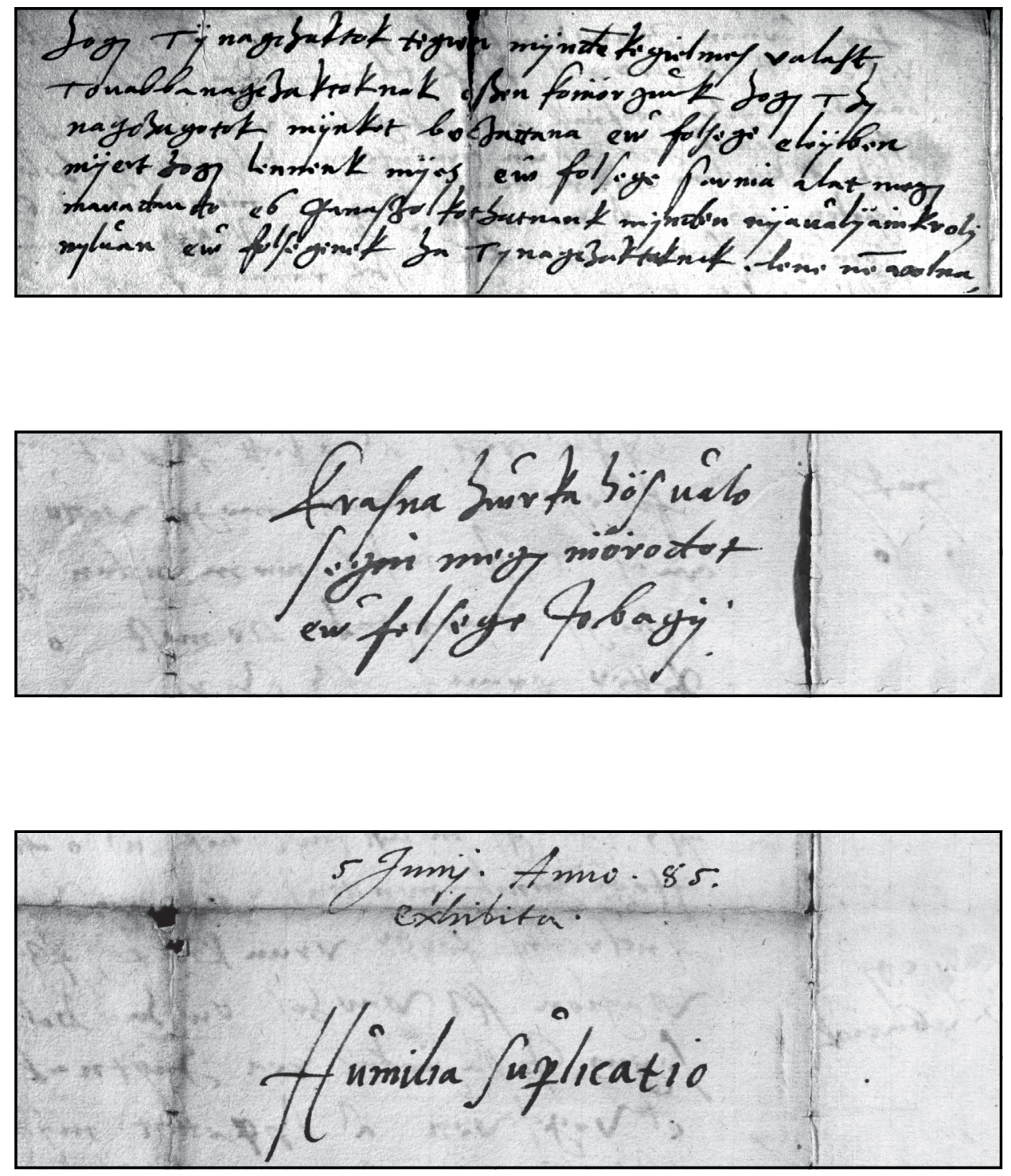
hogj Tÿ nagchaktok tegien mÿndē kegielmes valast, Touabba nagczaktoknak eszen koniörgŭnk hogj Thy nagczagotok mÿnket boczattana ew̆ folsege eleÿben mÿert hogj lennenk mÿes ew folsege sarnia alat megj maradando es panaszolkothatnank mÿnden nÿaŭalÿainkrolÿ nylŭan ew̆ folsegenek ha Ty nagczaktaknak elene ne volna,

Kivül:

Krasna hŭrka hös ŭalo segin megj niorodot ew̌ felsege Jobagÿ.

Más kezekkel írva:

5 Junÿ. Anno. 85. exhibita.

Hŭmilia sŭplicatio 
E $41-1585$ No. 14 .

Xagsagos es kegichn's reväm skaynak

16 Goreoke malo byinfegemet ayantom.

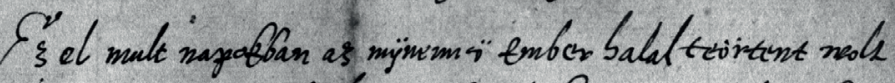

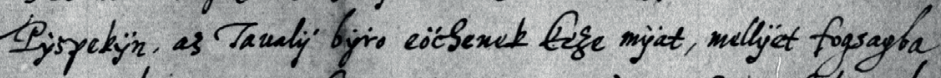

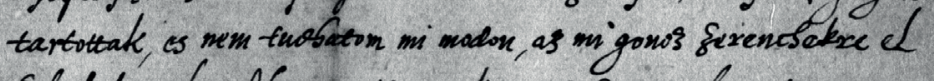
sabadult as buofohan mygion, mely gonos temo' emberent, as en

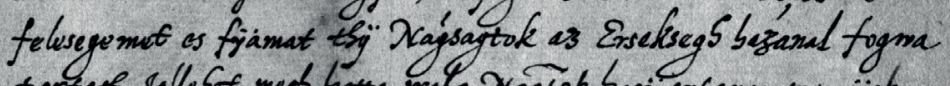

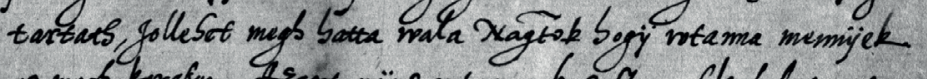

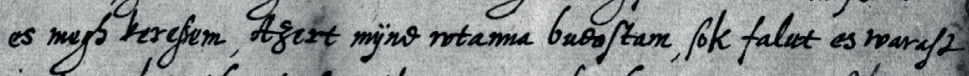
iartam el cretabe, de fummikepear nem kejbatom, mert as felescre

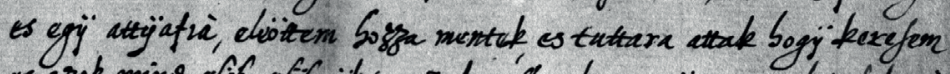

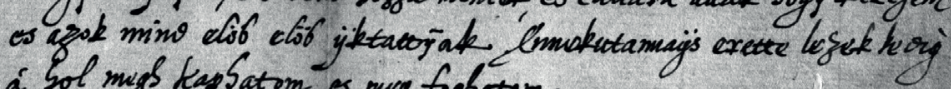
a sol mygh kapsatom, as mug foghatim.

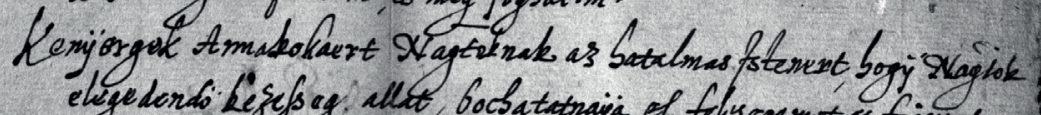

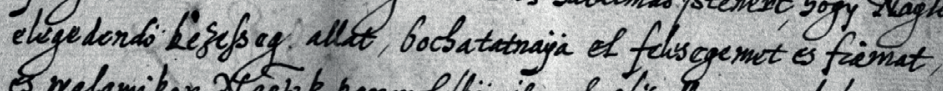

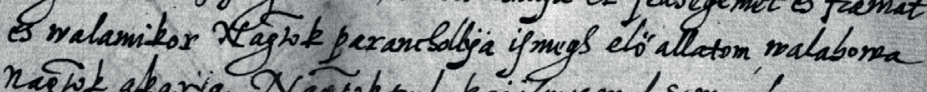

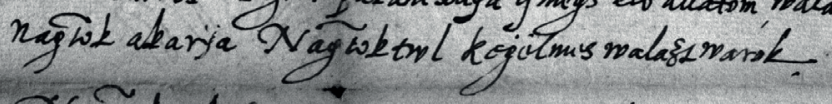

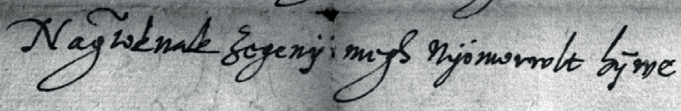

CSat Mate Pisively

foragi

134 


\section{I.23.}

Püspöki, 1585. VI. 15. Csát Máté levele.

Naǵsagos es keg̉elmes wraÿm Naḡnak

Eöreökke walo hÿwsegemet aÿanlom ${ }^{1}$.

Ez el mult napokban az mÿnemeö Ember halal teörtent wolt Pÿspekÿn, az Taualÿ bÿro eöchenek keze mÿat, mellÿet fogsagba tartottak, es nem tudhatom mi modon, az mi gonoz zerenchekre el zabadult es budosoban wagÿon, melÿ gonoz tewö emberert, az en felesegemet es fÿamat thÿ Naǵsagtok az Erseksegh hazanal fogwa tartath, Jollehet megh hatta wala Nağtok hogÿ wtanna mennÿek es megh keressem, Azert mÿnd wtanna budostam, sok falut es warast iartam el eretthe, de semmikeppen nem kaphatom, mert az felesege es egÿ attÿafia, eleöttem hozza mentek, es tuttara attak hogÿ keresem es azok mind elöb elöb ÿktattÿak Ennekutannaÿs erette lezek kedig

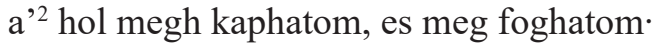

Kenÿergek Annakokaert Naḡtoknak az hatalmas Istenert, hogÿ Naḡtok elegedendö kezesseg allat, bochatatnaÿa el felesegemet es fiamat, es walamikor Naḡtok paranchollÿa ismegh elö allatom, walahowa Naḡtok akarÿa Naḡtoktwl kegelmes walazt warok

Naḡtoknak zegenÿ megh nÿomorwlt hÿwe

Chat Mathe Pÿspekÿ

Jobagÿ

\footnotetext{
${ }^{1}$ Az első $a$ fölötti ékezet szándéktalannak látszik.

${ }^{2} \mathrm{Az} a$-hoz tartozó ékezet feltehetően a $z$ hiányának jelzése.
} 


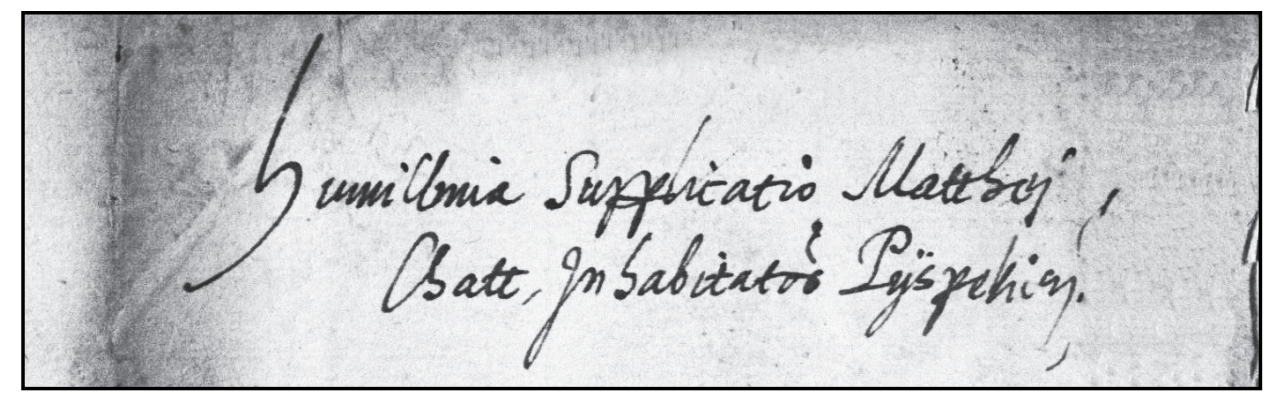

15 pung 85. 
Kívül:

Humillima Supplicatio Matthej

Chatt, Inhabitatoris Pÿspekiensis

Más kézzel írva:

15 Junÿ 85. 


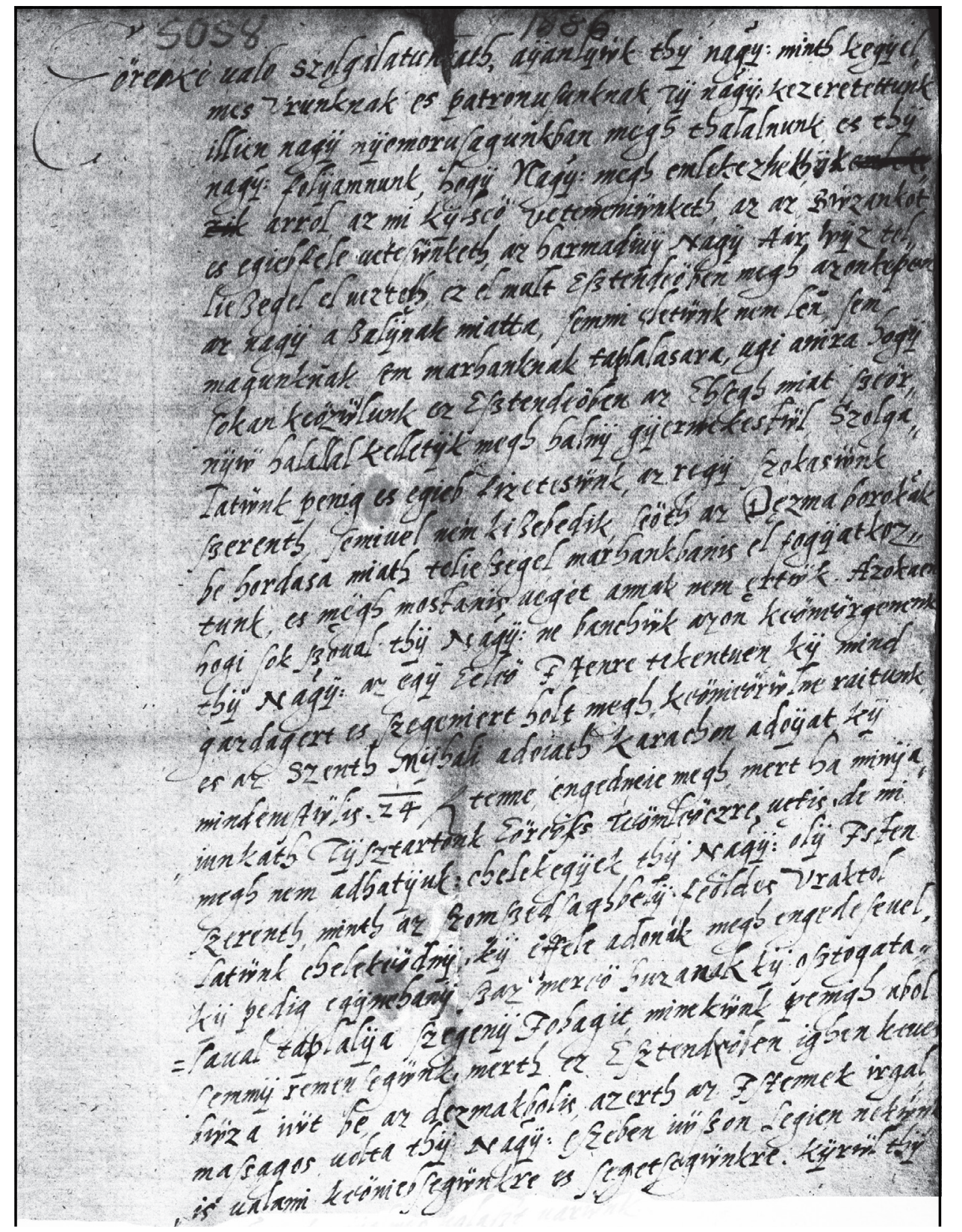




\section{I.24.}

Alsószerdahely-Felsöszerdahely, 1586. II. 3. vágszerdahelyi jobbágyok levele.

Eöreoke $^{1}$ ualo szolgalatunkath ${ }^{2}$, aÿanlÿẅk thy nağy: minth kegÿelmes Vrunknak es patronusunknak tÿ naḡ̈: kezeretettunk illien nagÿ nÿomorusagunkban megh thalalnunk es thÿ naḡy: folÿamnunk, hogÿ Naḡy: megh emlekezhethÿk ${ }^{3}<$ emlekezik> arrol az mi kÿlseö vetemeniẅnketh, az az Bẅzankot, es egiebfele uetesẅnketh, az harmadiuÿ Nagÿ Aár ${ }^{4}$ Wÿz tellieszegel el uezteth ${ }^{5}$, ez el mult Esztendeöben megh azonkepen az nagÿ aszalÿnak miatta, semmi eletẅnk nem leon, ${ }^{6}$ sem magunknak sem marhanknak taplalasara, ugi anira hogÿ sokan keözẅlunk ez Esztendeöben az Ehsegh miat szeörnÿẅ halallal kelletÿk megh halnÿ gÿermekestẅl, Szolgalatẅnk penig es egieb fizetesẅnk, az regÿ szokasẅnk szerenth, semiuel nem kiszebedik, seöth az Dęzma borokāk be hordasa miath teliessegel marhankbanis el fogÿatkoztunk, es męgh mostanis ueget annak nem ęrtẅk. Azokaert hogi sok szoual thÿ Naḡ̈̈: ne banchük azon keöneörgenenk thÿ Nagÿ: az egÿ Eeleö Istenre tekentuen kÿ mind gazdagert es szegeniert holt megh, keönieörẅlne raitunk, es az Szenth Mÿhali adoiath Karachon adoÿat kÿ mindenestẅlis. 24 florenorum tenne, engedneie megh, mert ha minÿaiunkath Tÿsztartonk Eöreöss ${ }^{7}$ Teömleöczre uętis, de mi megh nem adhatÿuk: chelekegÿek thÿ Nagÿ: olÿ Isten szerenth, minth az szomszedsaghbelÿ feöldes Vraktol latẅnk chelekeödnÿ, kÿ effele adonak megh engedeseuel, kÿ pedig egÿnehanÿ szaz mereö buzanak kÿ osztogata-saual taplalÿa szegenÿ Jobagit, minekẅnk penigh abol semmÿ remensegẅnk, merth ez Esztendeöben ighen keues büza iẅt be, az dezmakbolis, azerth az Istennek irgalmassagos uolta thÿ Nağ̈: eszeben iẅsson, Legien nekẅnkis ualami keöniebsegünkre es segetsegẅnkre. kÿrẅl thÿ

\footnotetext{
${ }^{1}$ Az $o$ javított betü, talán $e$-ből.

${ }^{2} \mathrm{~A} k$ helyén sérült a papír.

${ }^{3}$ A szó utolsó szótagján többféle javítás nyoma látszik.

${ }^{4} \mathrm{~A}$ második $a$ fölötti pont funkciója ismeretlen.

${ }^{5} \mathrm{~A}$ második $t$ javított betünek látszik.

${ }^{6} \mathrm{Az} o$ interlineáris betoldás.

${ }^{7}$ Az első $s k$-ból javított betü.
} 

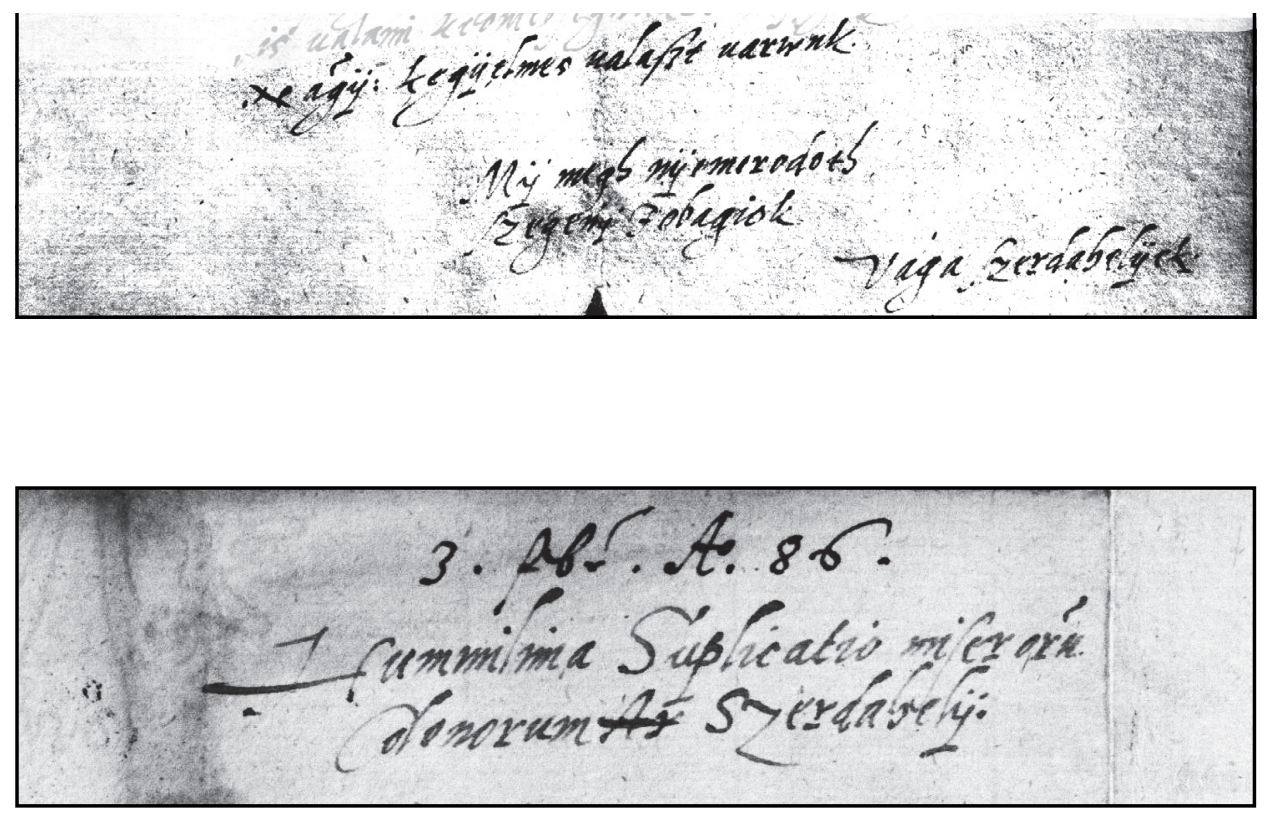
Naḡÿ: kegÿelmes ualaszt uarwnk.

Mÿ megh nÿomorodoth

szegenÿ Jobagiok

Vaga szerdahelÿek

Kívül:

3. februarius Anno. 86.

Hummilima Suplicatio miserorum

Colonorum $<$ ar $>$ Szerdahelÿ. 


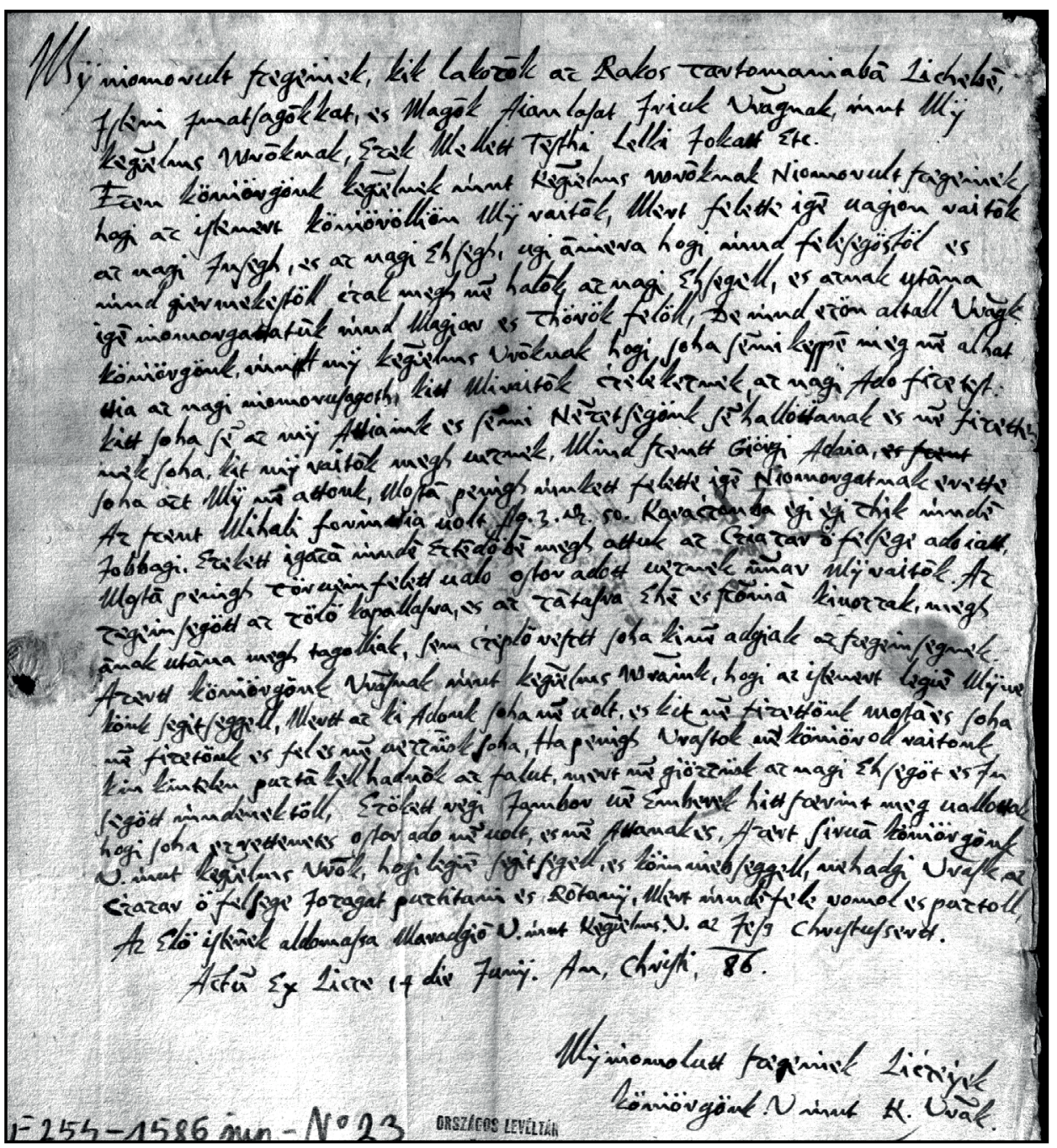




\section{I.25.}

Lice, 1586. VI. 14. Licei jobbágyok levele.

Mÿ niomorult szegeniek, kik lakozōk az Rakos Tartomaniabā Lichebē, Isteni Imatsagōkkat, es Magōk Aianlasat Iriuk Vrăgnak, mint ${ }^{1}$ Mÿ kegielmes Wroknak, Ezek Mellett Testhi Lelki Jokatt Etc.

Ezen köniörgönk kegielnek mint keḡielmes wroknak Niomorult szegeniek, hogi az istenert köniörölliön Mÿ raitō, Mert felette igē uagion raitok az nagi Insegh, es az nagi Ehsegh, ugi āniera hogi mind felesegöstöl es mind giermekestöll ćzak megh nē halōk, az nagi Ehsegell, es aznak utāna ige niomorgattatuk mind Magiar es Thörök felöll, De mind ezön altall Vragk köniörgönk, $\min <\mathrm{d}>\mathrm{t}$ mÿ kegielmes Vroknak hogi soha semmikeppe meg ne alhat ttia az nagi niomorusagoth, kitt Miraitok ćzelekeznek, az nagi Ado fizetest: kitt soha se az mÿ Attiaink es sēmi Nēzetsegönk sē hallottanak es ne fizettenek soha, kit mÿ raitok megh ueznek, Mind szentt Giörgi Adaia, <es szent> soha azt Mÿ nē attonk, Mosta penigh minkett felette ige Niomorgatnak erette Az szent Mihali forinttia uolt florenorum 3. denariorum 50. Karaćzonba egi egi Thik

Jobbagi. Ezekett igazā mindē Eztēëöbē megh attuk az Cziazar ö felsege adoiatt, Mostā penigh Töruein felett ualo ostor adott ueznek imar Mÿ raitok. Az zegeinsegött az zölö kapallasra, es az zātasra Ehe es szōuiā kinozzak, megh ānak utāna megh tagolliak, sem ćzeplö resztt soha kine adgiak az szegeinsegnek. Azertt köniörgönk Vrasnak mint kegielmes Wraink, hogi az istenert legiē Mÿne könk segitseggell, Mertt az ki Adonk soha nē uolt, es kit nē fizettönk mostāes soha ne fizetönk es fel es nē uezz $\bar{w} k$ soha, Ha penigh Vrastok nē köniöroll raitonk, kin kintelen puztā kell hadnōk az falut, mert ne giözzẅk az nagi Ehsegöt es In segött mindenektöll, Ezökett regi Jambor ue Emberek hitt szerint meg uallottak hogi soha ez rettenetes ostor ado nē uolt, es nē Attanakes, Azert sirua köniörgönk V. mint kegielmes Vrok, hogi legiē segitsegell, es köinniebseggell, nehadgi Vrask, az ćzazar ö felsege Jozagat puztitani es Rōtanÿ, Mert mindēfele romol es puztoll, Az Elö istēnek aldomassa Maradgiō V. mint Kegielmes V. az Iesus Christussertt. Actum Ex Licce, 14 die Junÿ. Anno, Christi, 86.

Mÿ niomolutt szegeniek Lićzeÿek köniörgönk V mint K. Vrak.

\footnotetext{
${ }^{1}$ Az $m$ jobboldali szára az $i$-t vagy az $e$-t is jelezheti ebben a levélben több helyen (utóbbira 1. például a következő sorban: keḡielmes).
} 

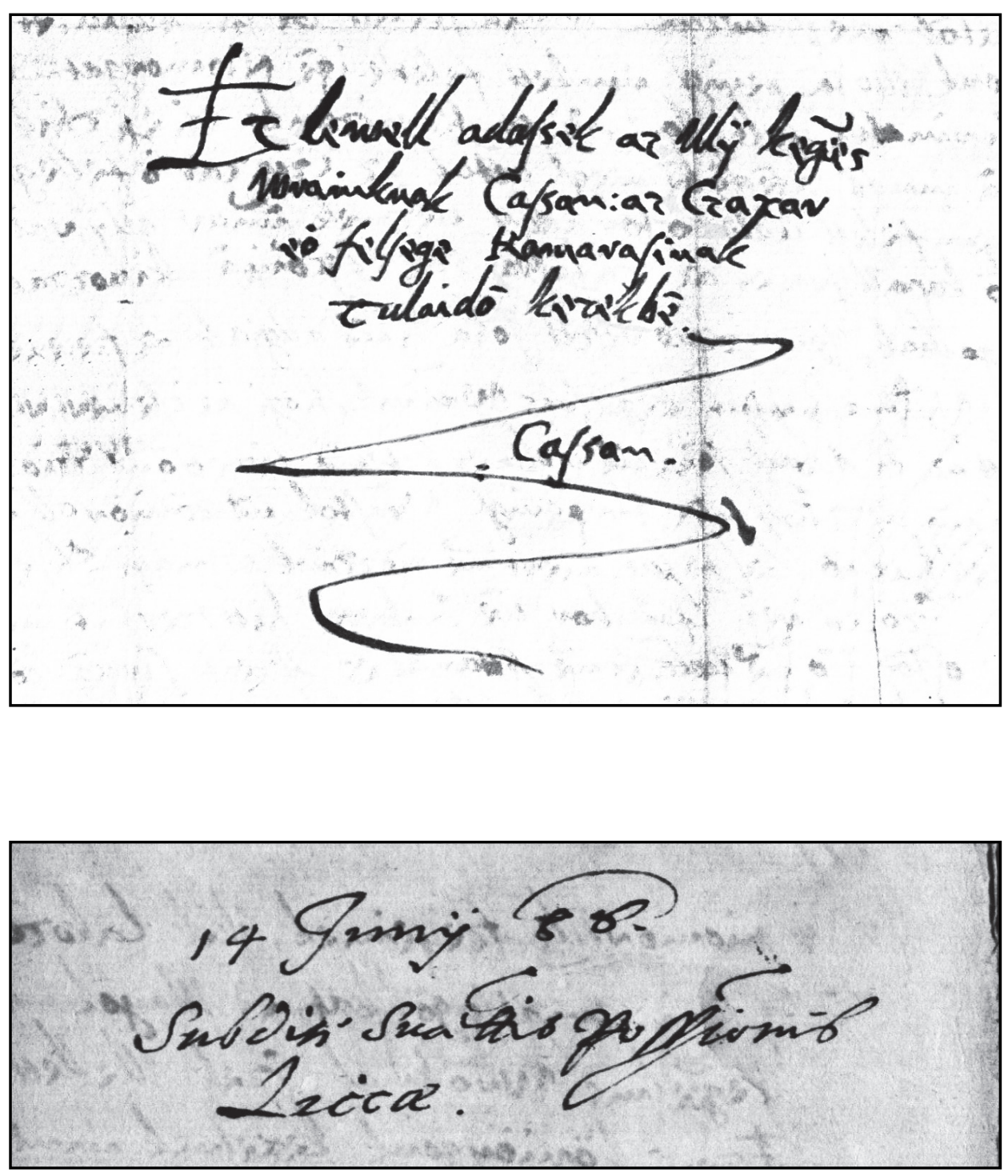

144 
Kìvül:

Ez lewell adassek az Mÿ keḡies

wrainknak Cassan: az Czazar ${ }^{2}$

eö felsege Kamarasinak

Tulaido kezekbē.

Cassan.

Más kézzel irva:

14 Junÿ 86.

Subditi Suae Maiestatis possessionis

Liccae.

${ }^{2} \mathrm{~A} z$ javításnak tünik $s$-böl. 
E 254 - 1587. márc. №. 33.

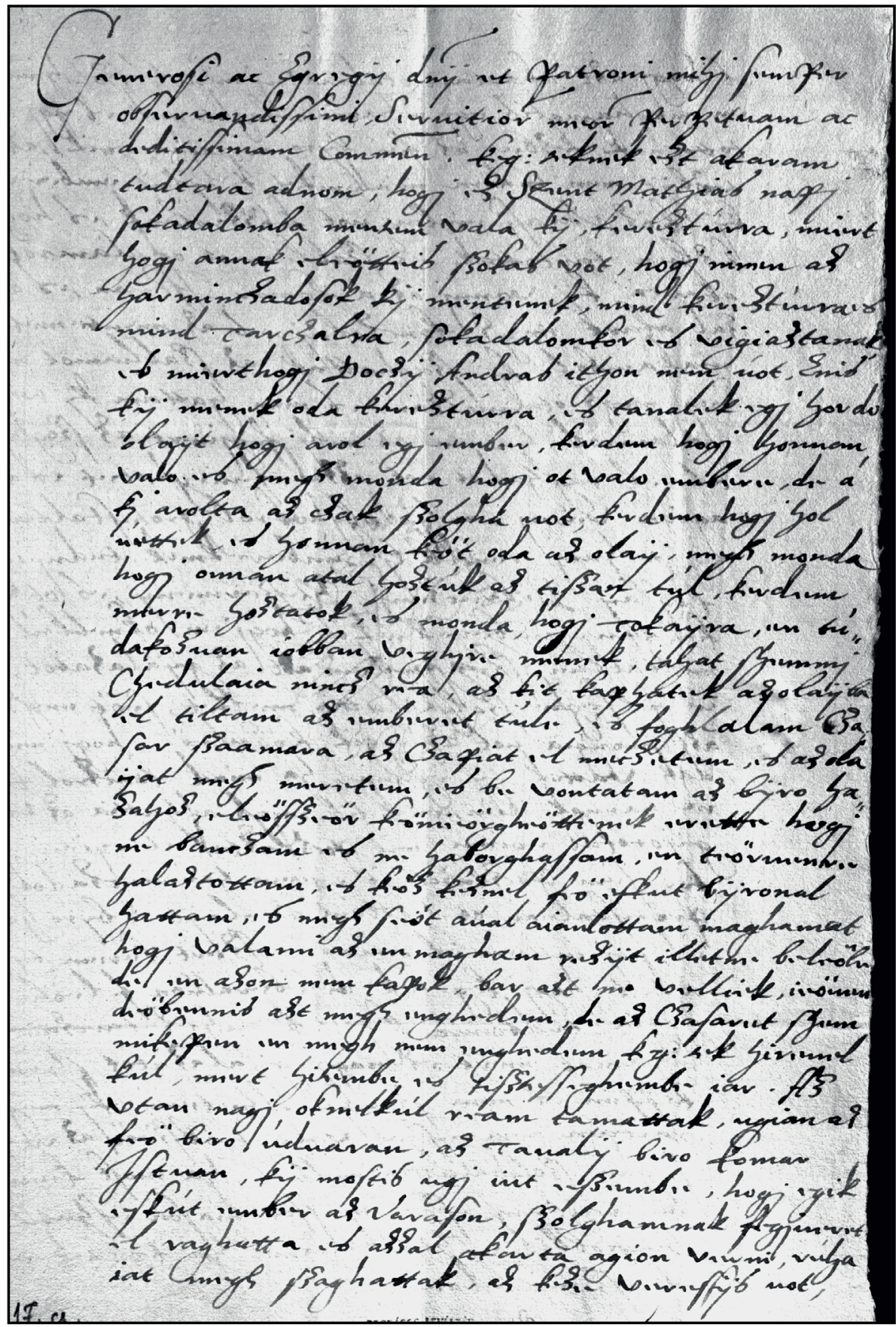




\section{I.26.}

Tokaj, 1587. III. 7. Somody Zsigmond levele.

Generosi ac Egregÿ dominÿ et patroni mihj semper obseruandissimi, Seruitiorum meorum perpetuam ac deditissimam Commendationem. keg:teknek ezt akaram tudtara adnom, hogj ez szent Mathias napj sokadalomba mentem vala kÿ, kereztúrra, miert hogj annak eleötteis szokas vot, hogj innen az harminczadosok kÿ mentenek, mind kereztúrrais mind Tarczalra, sokadalomkor es vigiaztanak, es mierthogj Doczÿ Andras ithon nem úot, Enis kÿ menek oda kereztúrra, es tanalek egj hordo olaÿt hogj arol egj ember, kerdem hogj honnan, valo es megh monda hogj ot valo embere, de a kj arolta az czak szolgha uot, kerdem hogj hol úettek es honnan keőt oda az olaÿ, megh monda hogj onnan atal hoztúk az tiszan túl, kerdem merre hoztatok, es monda, hogj Tokaÿra, en túdakozuan iobban veghjre menek, tahat shemmj Chedulaia nincz rea, az kit kaphatek az olaÿba el tiltam az emberet túle, es foghlalam Czasar szaamara, az Czapiat el meczetem, es az ola ÿat megh meretem, es be vontatam az bÿro hazahoz, eleősszeőr keőnieőrgheőttenek erette hogj ne banczam es ne haborghassam, en teöruenre halaztottam, es keőz keznel feö eskut bÿronal hattam, es megh seöt aúal aianlottam maghamat hogj valami az en magham rezÿt illetne beleöle de en azon nem kapok, bar azt ne velliek, ieőuen deöbennis azt megh enghedem, de az Czasaret shem mikepen en megh nem enghedem keg:tek hirenel kúl, mert hitembe es tisztesseghembe iar. Az vtan nagj oknelkúl ream tamattak, ugianaz feö biro úduaran, az Taualÿ biro komar Istuan, kÿ mostis ugj iut eszembe, hogj egik eskút ember az Varason, szolghamnak fegjueret el raghatta es azzal akarta agion verni, rúha iat megh szaghattak, az keze veressÿs uot, 


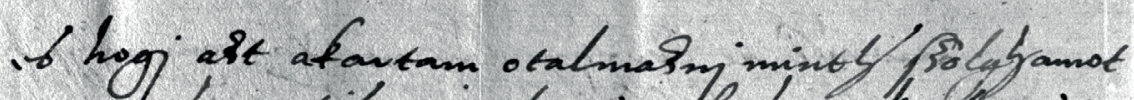

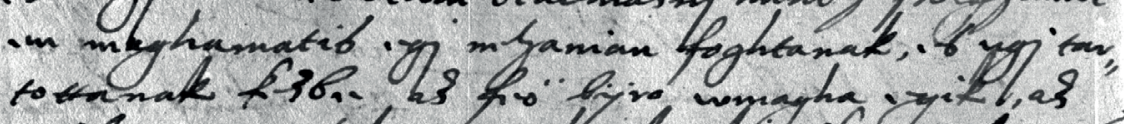
K.

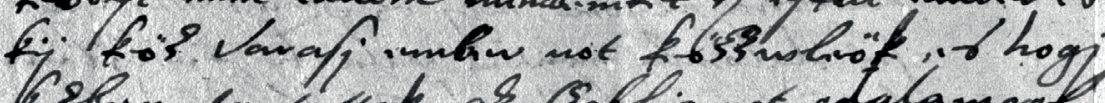

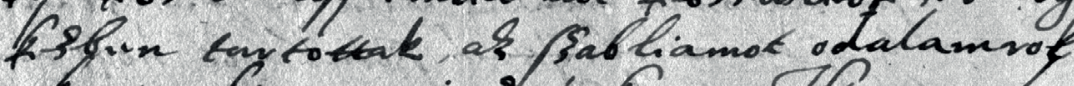

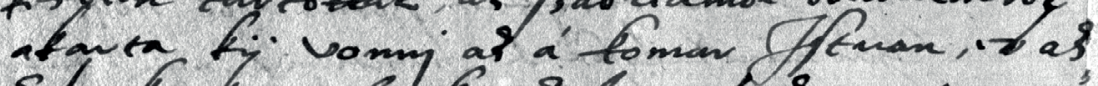

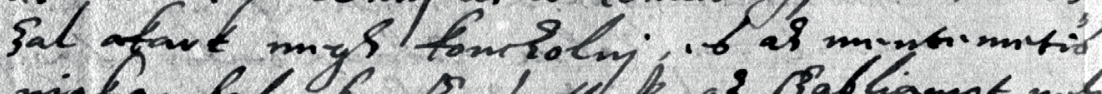
mintambol fol sayhatthe, as pablamos my

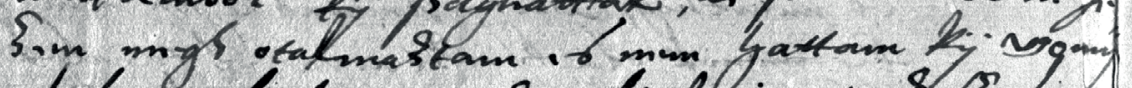

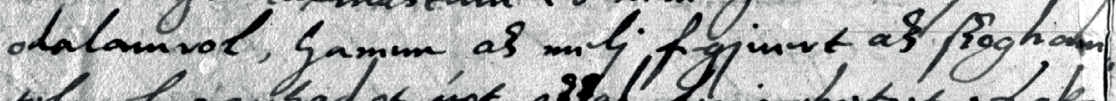

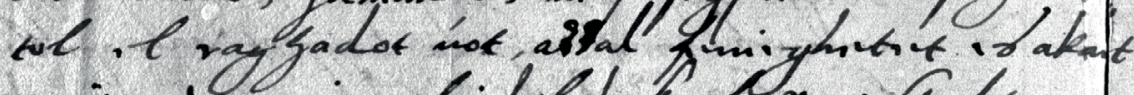
agion any - if dolyhafrol prosy fallam

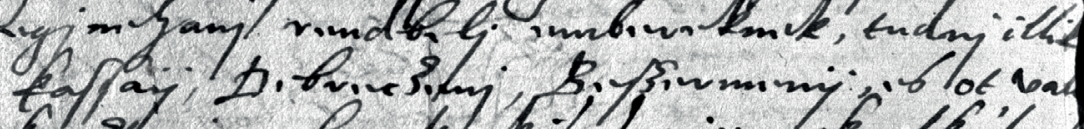

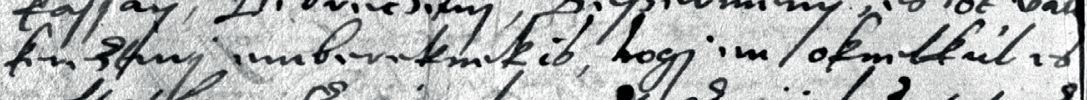

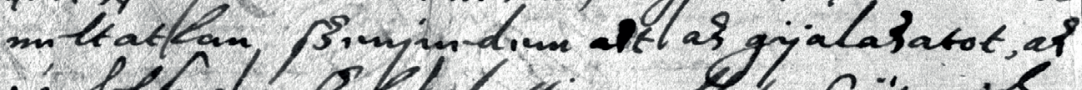

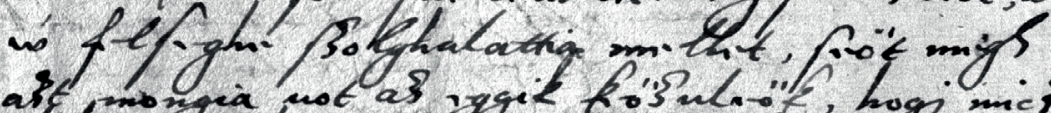

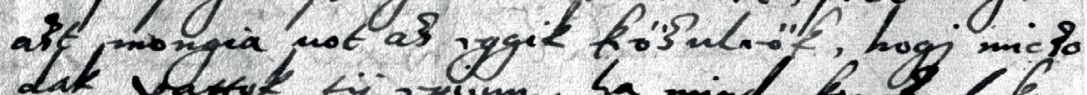

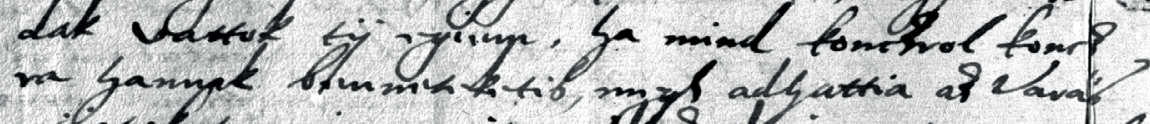

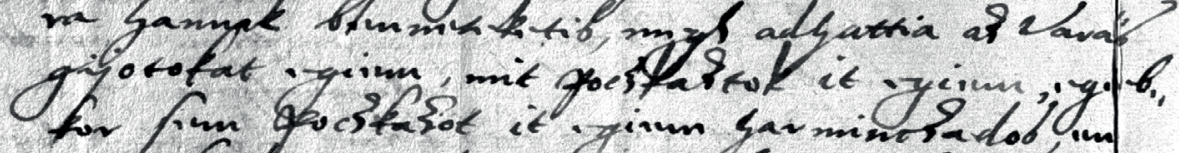
pronf

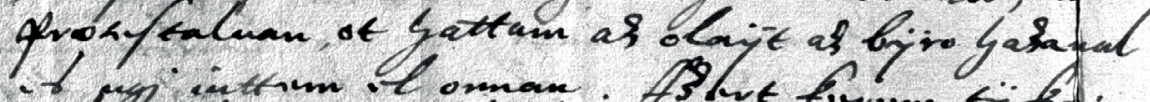

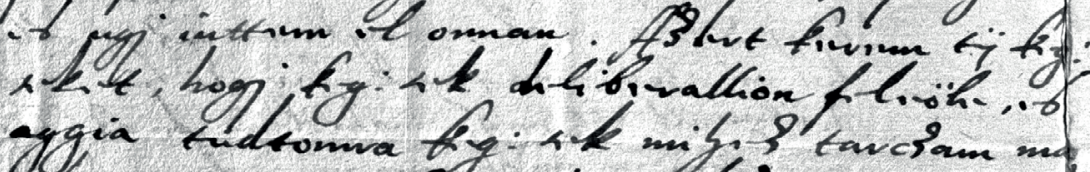
a amat mut

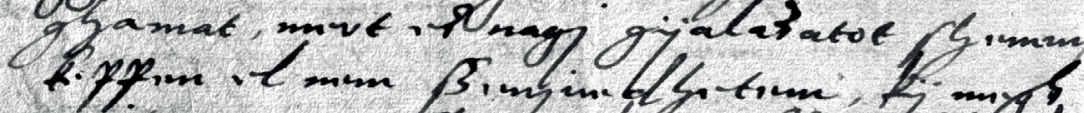

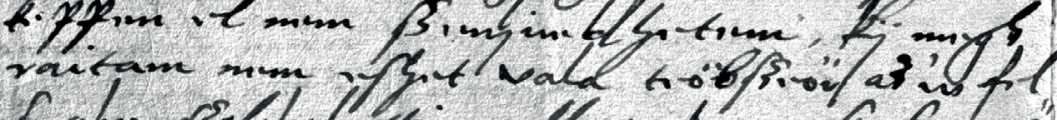

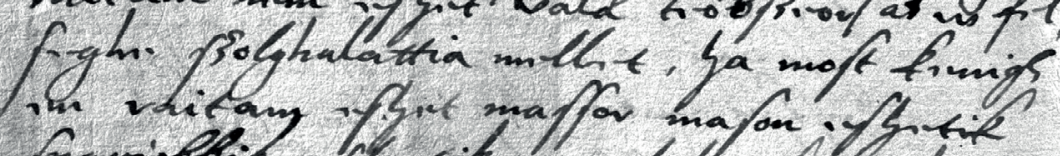

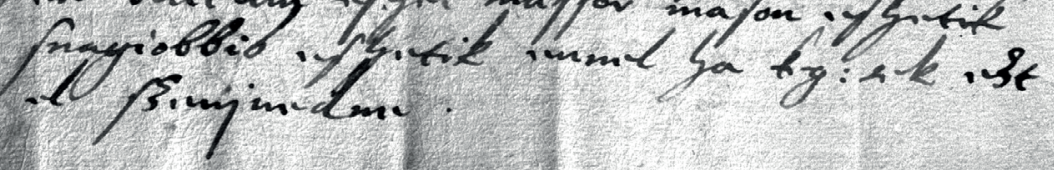


es hogj azt akartam otalmaznj minth szolghamot en maghamatis egj nehanian foghtanak, es ugj tartottanak kezbe az feö bÿro wmagha egik, az teőbÿt nem túdom mindeniket kj eskut ember es kÿ keőz Varasj ember uot keőzzwleök, es hogj kezben tartottak, az szabliamot odalamrol akarta kÿ vonnj az a ${ }^{1}$ komar Istuan, es azzal akart megh konczolnj, es az mentemetis niakambol kÿ szaghattak, az szabliamot nehezen megh otalmaztam es nem hattam kÿ vonnj ${ }^{2}$ odalamrol, hanem az melj fegjuert az szoghamtol el raghadot úot, azzal fenieghetet es akart agion vernj, melj dolghokrol ${ }^{3}$ protestaltam egjnehanj rendbelj embereknek, tudnj illik kassaÿ, Debreczenj, Beszermenÿ, es ot valo kerezturj embereknekis, hogj en oknelkúl es meltatlan szenjuedem azt az gÿalazatot, az ẃ felseghe szolghalattia mellet, seőt megh azt mongia uot az eggik kőzuleők, hogj miczo dak vattok tÿ egiem, ha mind konczrol konczra hannak benneteketis, megh adhattia az Varas gÿotokat egiem, mit poczkaztok it egiem, egiebkor sem poczkazot it egiem harminczados, en protestaluan, ot hattam az olaÿt az bÿro hazanal es ugj iuttem el onnan. Azert kerem tÿ keg: teket, hogj keg:tek deliberallion feleőle, es aggia tudtomra keg:tek mihez tarczam maghamat, mert ez nagj gÿalazatot shemmj keppen el nem szenjuedhetem, kÿ megh raitam nem eshet vala teőbszeőr az ẃ felseghe szolghalattia mellet, ha most kenigh en raitam eshet massor mason eshetik snagiobbis eshetik ennel ha keg:tek ezt el szenjuedne.

\footnotetext{
${ }^{1} \mathrm{Az}$ a fölötti vonás funkciója ismeretlen.

${ }^{2} \mathrm{~A} v$ után talán téves betü nyoma látszik.

${ }^{3} \mathrm{Az}$ első $o$ javított betü.
} 


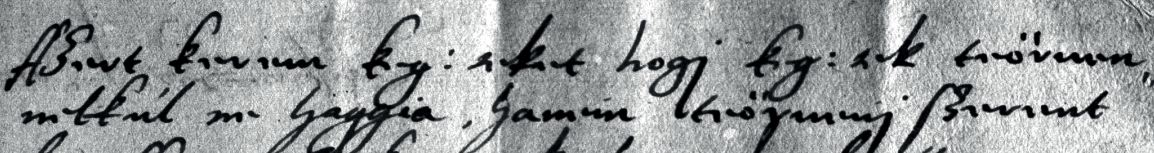

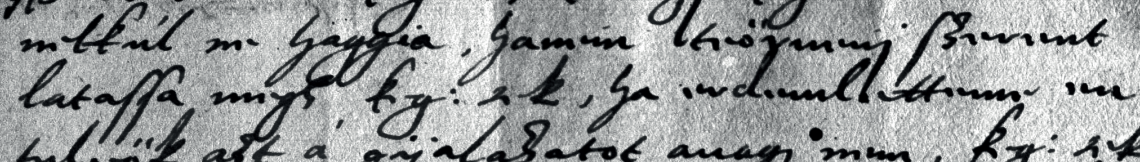

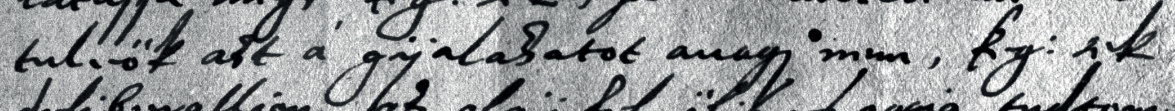

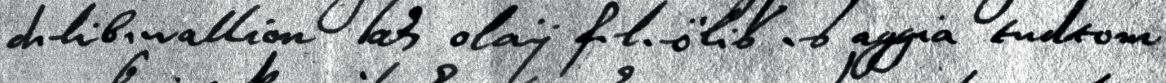
ra kg: ak mighs lan shom, my hamat, nut

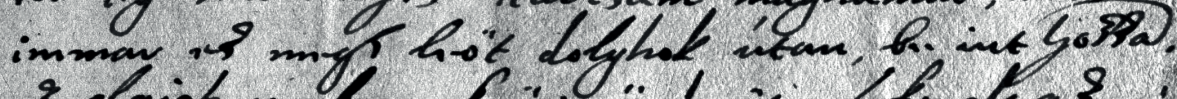

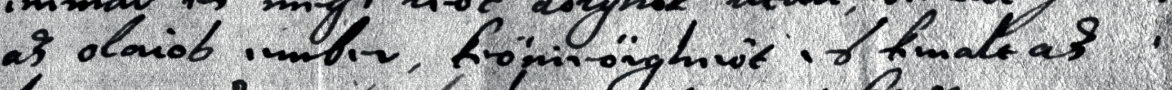

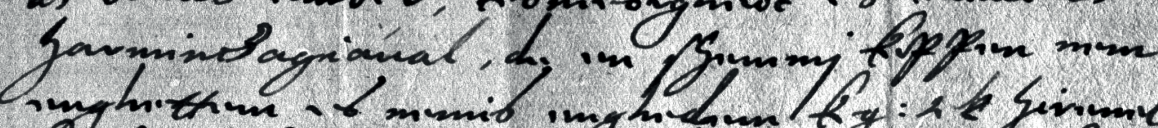

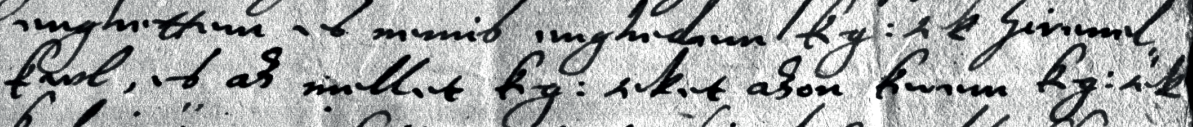

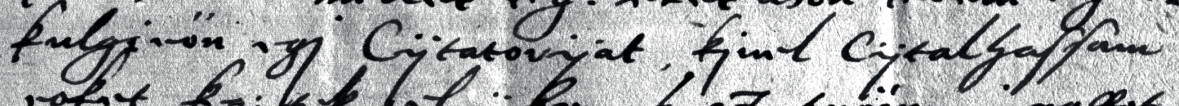
ofet fg.

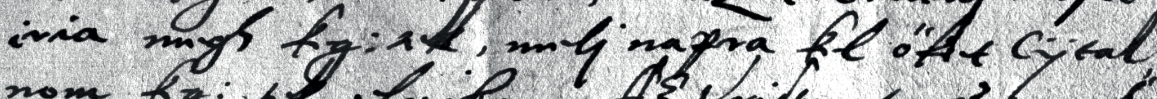

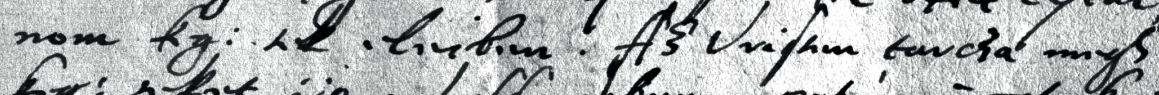

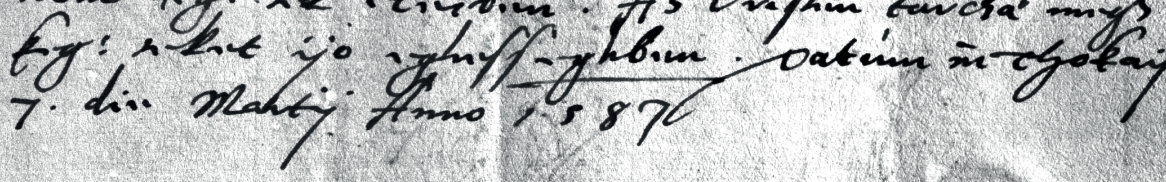

Eg: akiul mindim

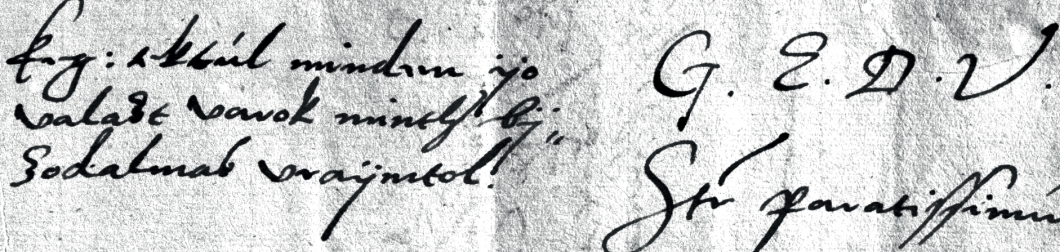

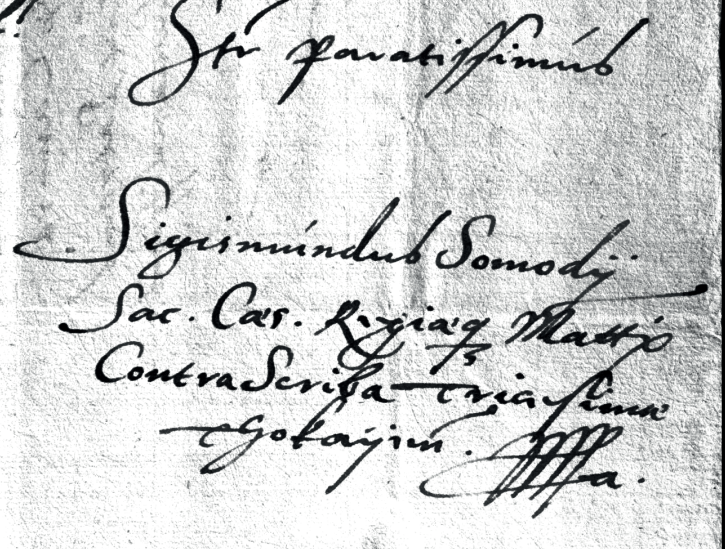


Azert kerem keg:teket hogj keg:tek teőruennelkúl ne haggia, hanem teöruenj szerent latassa megh, keg:tek, ha erdemletteme en tuleők azt a ${ }^{4}$ gÿalazatot auagj nem, keg:tek deliberallion az olaÿ feleőlis es aggia tudtom ra keg:tek mihez tarczam maghamat, mert immar ez megh leöt dolghok útan, be iut hozzā az olaios ember, keőnieőrgheőt es keualt az harminczagiaúal, de en shemmj keppen nem enghettem es nemis enghedem keg:tek hirenelkwl, es az mellet keg:teket azon kerem keg:tek kulgieőn egj Cÿtatorÿat, kjuel Cÿtalhassam eoket keg:tek eleÿbe, es az ${ }^{5}$ teöruenj napot iria megh keg:tek, melj napra kel öket Cÿtalnom keg:tek eleiben. Az Vristen tarcza megh keg:teket ÿo eghesseghben. Datúm in Thokaÿ 7. die Martÿ Anno 1587

keg:tekúl minden ÿo valazt varok minth bÿzoldalmas vraÿmtol.
Generosae Egregiae Dominationis Vestrae Servitor paratissimús

Sigismúndus Somodÿ

Sacrae Caesariae Regiaeque Maiestatis

Contra Scriba Triaesimae

Thokaÿensis. Manu propria.

${ }^{4}$ L. az 1. számú lábjegyzetet.

${ }^{5} \mathrm{~A} z$ javított betü. 

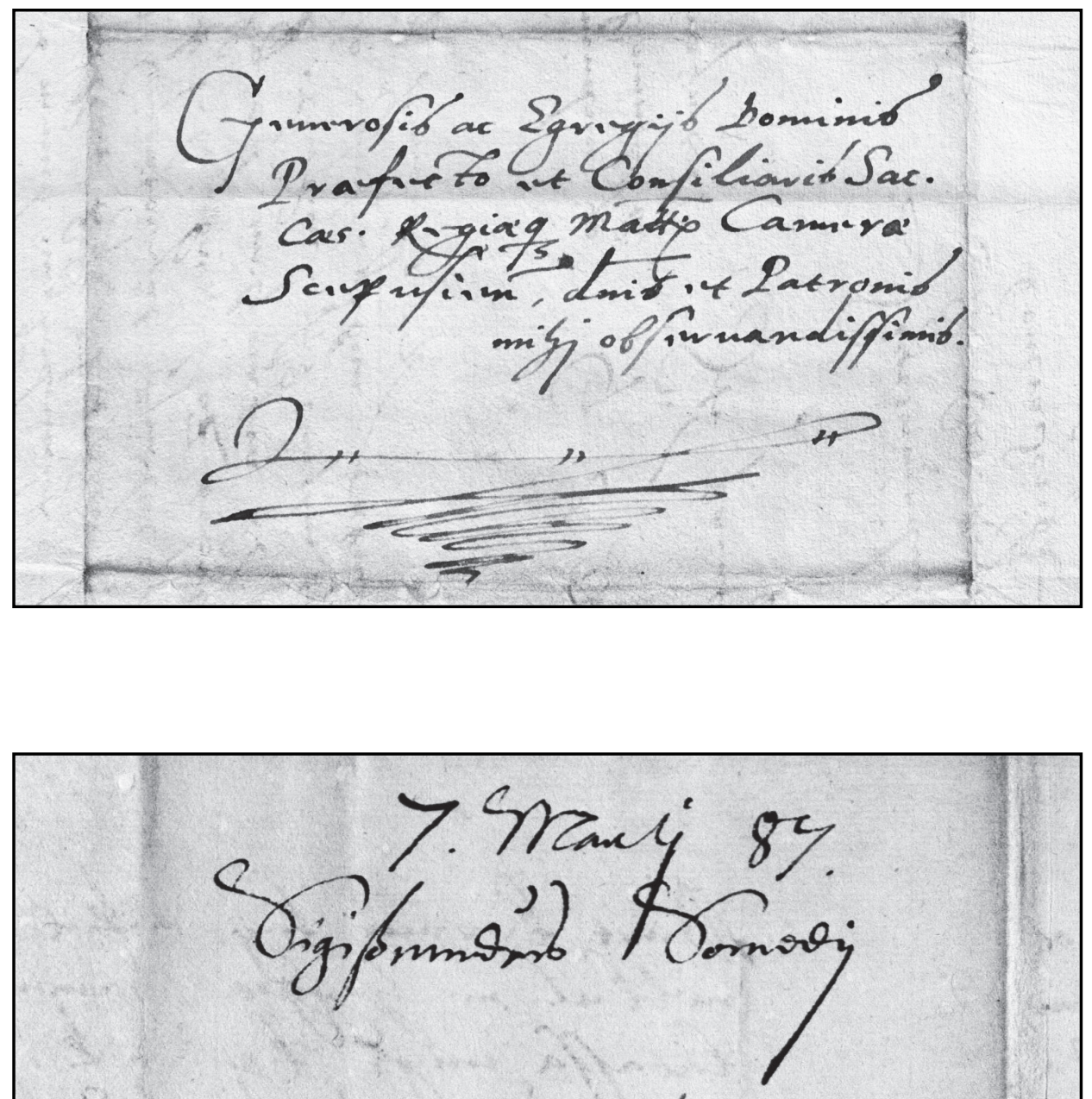
Kivül:

Generosis ac Egregÿs Dominis

Praefecto et Consiliaris Sacris

Caesareae Regiaeque Maiestatis Cameræ

Scepusiensis, dominis et Patronis

mihj obseruandissimis.

etc

Más kézzel írva:

7. Martj 87.

Sigissmundŭs Somody் 


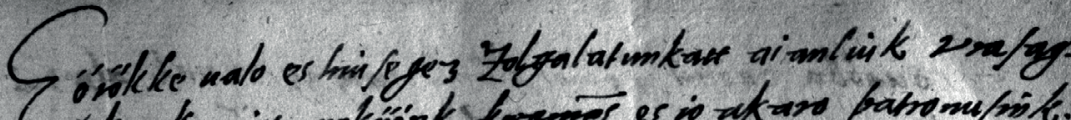

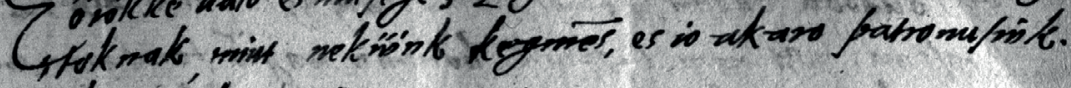
" satk ó félgere wans.

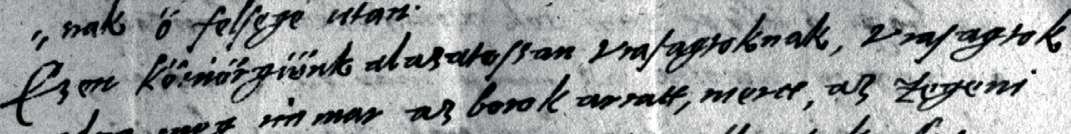

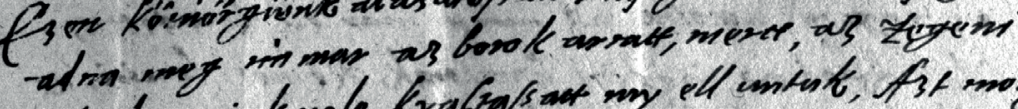

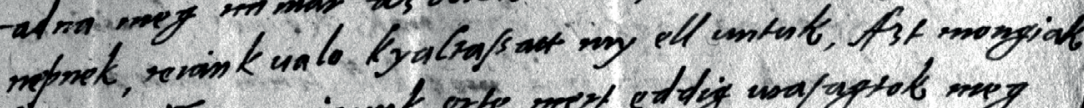

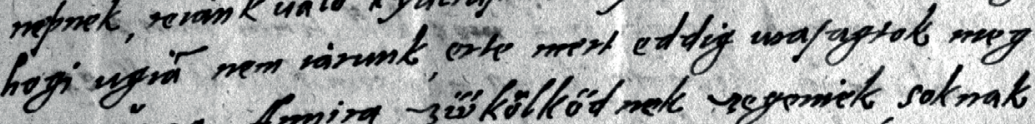

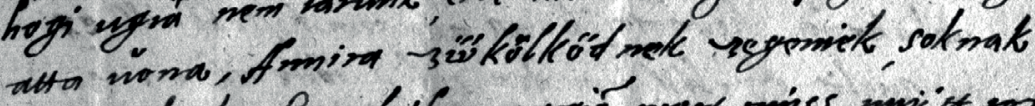

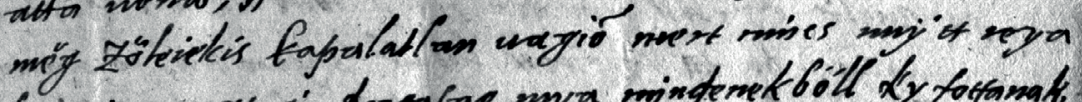

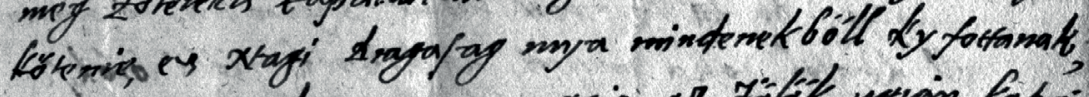

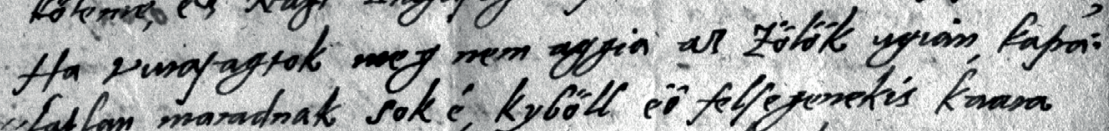

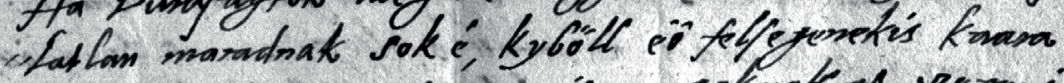

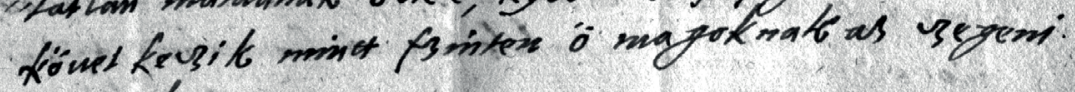
mepinet.

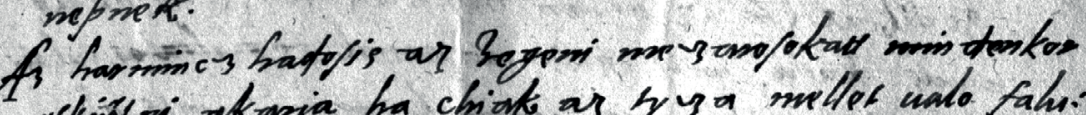
ofkistri aktaria, ha chichte as by sa melles ualo falu. "foon weyit as marbatis, ky mya ey uy mes aro frile

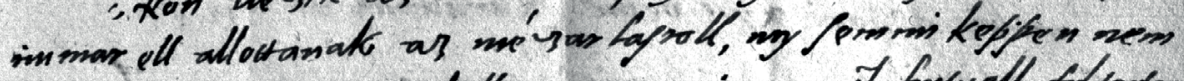

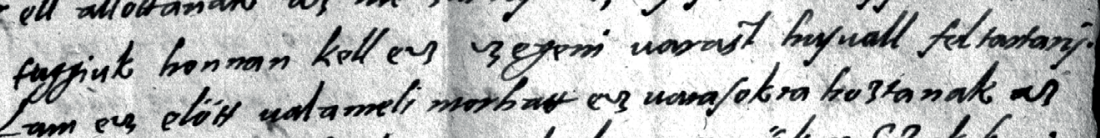

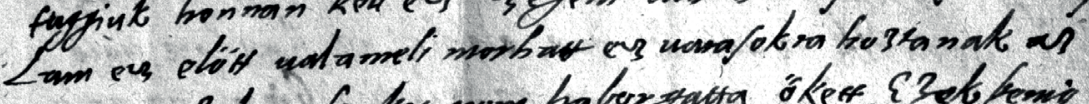

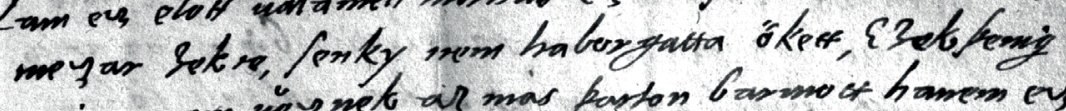
ugion mem wesnet as mas fapton barmo ot hamen ers ite käsell wallo falukon marafokin.

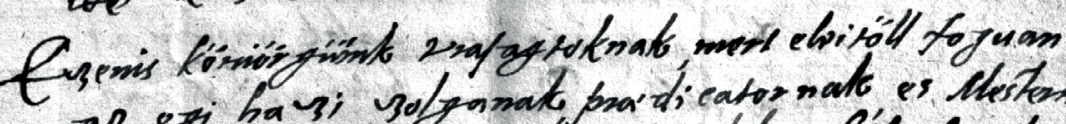
as efi ha si solfanat, praidicatornate es chesternet

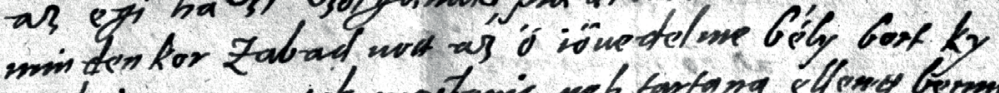

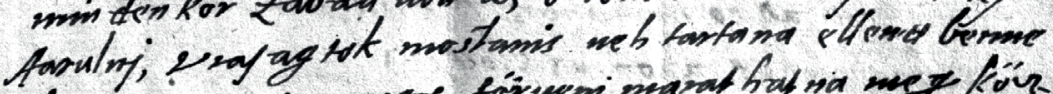

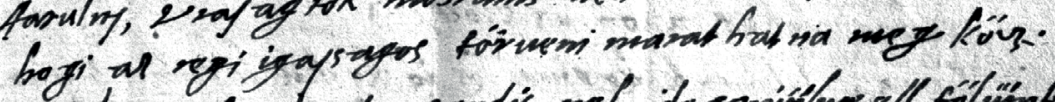

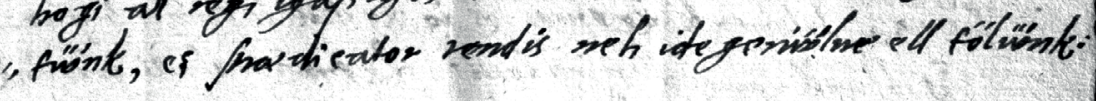




\section{I.27.}

Tarcal, 1587. VII. 13 elött. Kovács János tarcali föbíró levele (a város nevében).

Eőrőkke ualo es hiusegez Zolgalatunkatt aianliuk vrasag-toknak mint nekwwnk keḡmes, es io akaro patronusink-nak ö felsege utan.

Ezen kőniőrgw"nk alazatossan vrasagtoknak, vrasagtok adna meg immar az borok arratt, mertt, az Zegeni nepnek, reiank ualo kyaltassatt my ell untuk, Azt mongiak hogi ugiā nem iarunk, erte mert eddig urasagtok meg atta ŭona, Annira zw"kőlkődnek zegeniek, soknak měg Zőleiekis kapalatlan uagiō mert nincs mÿtt ${ }^{1}$ reya kőtenie, es Nagi Dragasag mya mindenekbőll ky fottanak, Ha vurasagtok meg nem aggia az zőlök ugian kapa-latlan maradnak sok é, kybőll eő felsegenekis kaara kőuetkezik mintt szinten ő magoknak az zegeni nepnek.

Az harmincz hadosis az zegeni mezarosokatt mindenkor eskw'tni akaria, ha chiak az tyza mellet ualo falu-kon uezik az marhatis, ky mya ez my mezarosink immar ${ }^{2}$ ell allottanak az mézarlasroll, my semmi keppen nem tuggiuk honnan kell ez zegeni uarast husuall feltartanj. Lam ez elött ualameli morhatt ez uarasokra hoztanak az mezar zekre, senky nem haborgatta ökett, Ezek penig ugian nem ŭeznek az mas parton barmott hanem ez ittē kőzell uallo falukon uarasokon.

Ezenis kőniőrgw"nk Vrasagtoknak, mert eleitőll foguan az egi hazi zolganak, praedicatornak, es Mesternek, minden kor Zabad uott az ő iőuedelme bély bort ky Aarulnj, Vrasagtok mostanis neh tartana ellentt benne hogi az regi igassagos tőrueni marathatna meg kőz-twwnk, ez praedicator rendis neh idegenwwlne ell tölw̋nk:

${ }^{1} \mathrm{Az} m$-nek eggyel több szára van.

${ }^{2} \mathrm{~A}$ szó betoldás a sor elejére. 


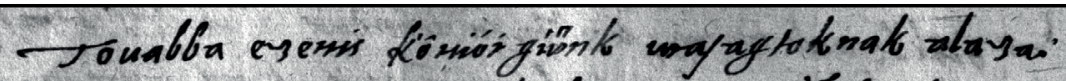
"tofian, ast men tuggint horiman wajió fondamento. - ma, hogi ófelfege enri sol xuemglefere blanteall be

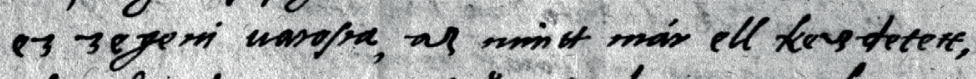

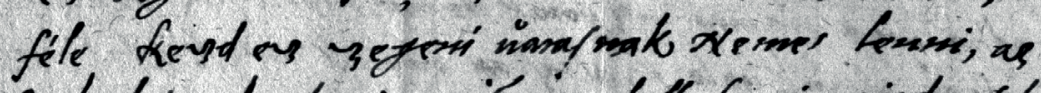
Molfatal mak perng ngid mge kell hermi minten tele

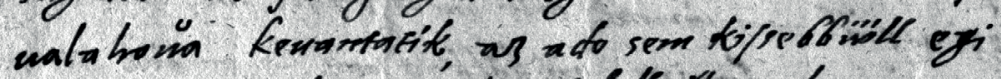

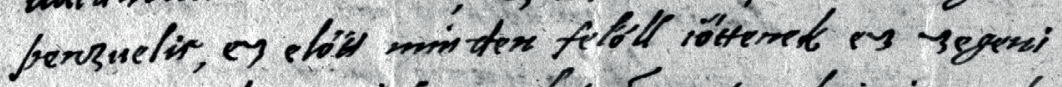

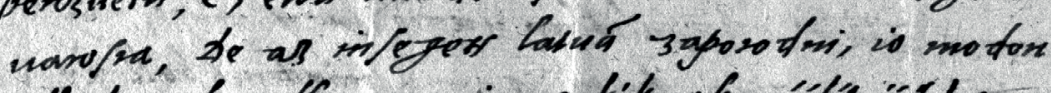

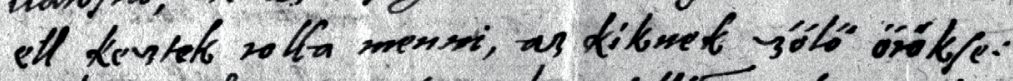

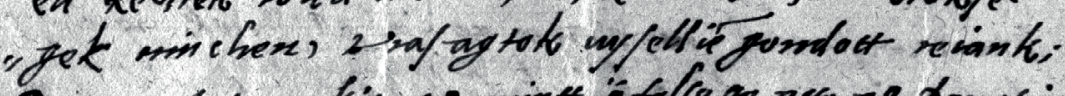

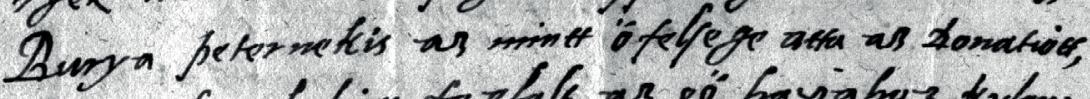
moes has helied toglale as 20 baviaho 3 , tyken credile as kin az ómön hasa uajion, fi yedilas

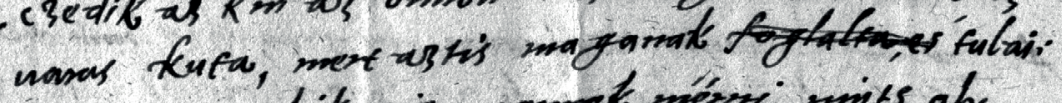
foritfia, as kik revia mermete mérm, miks ofy

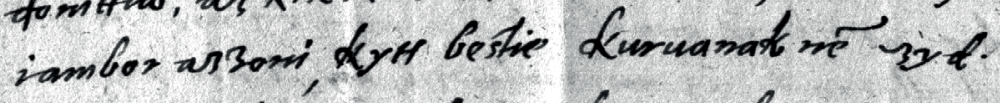

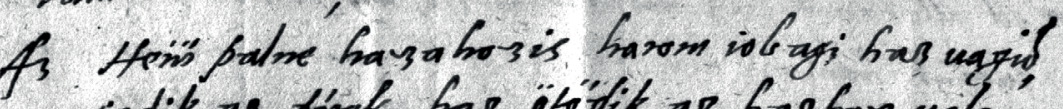
nepiedit, as térek has, ötolfit as hashor wato pin e-3e has, as tonte fectekesis Girng atearia

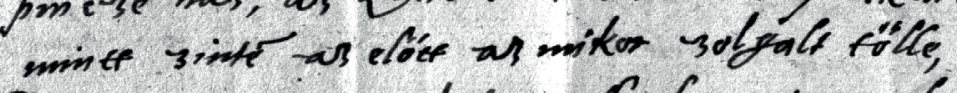
Zunya peteris ason kefpere, $A_{3}$ has war seats fidek perig $X_{\text {em }}$ ss has utan walot hamem as tik soffatrate fölle, Irunya piptex'as thy has helieker as eö hasahos fo glate, minderiker iobaji latiou azon as elbite.

As vus htermet kefmes es is Xedue legien shayag. fok uall mind tientirnt. Kegmer uatast wanmb irajagroktoll.

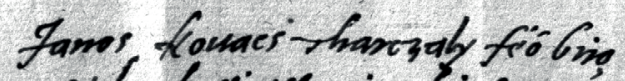

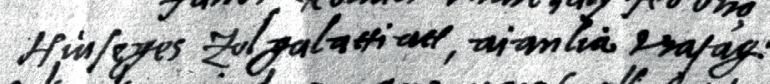

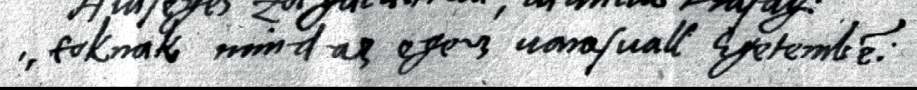

156 
Touabba ezenis kőniőrgw̋nk urasagtoknak alaza-tossan, azt nem tuggiuk honnan uagiō fondamento-ma, hogi ö felsege enni sok Nemessekett plantall be ez zegeni uarosra, az mintt már ell kezdetett, féle kezd ez zegeni ŭarasnak Nemes lenni, az szolgalatnak penig ugiā meg kell lenni minden fele ualahoŭa keuantatik, az ado sem kissebbwill egi penzuelis ${ }^{3}$, ez elött minden felőll iőttenek ez zegeni uarosra, De az insegett latua zaporodni, io modon ell keztek rolla menni, az kiknek zőlő őrőkse-gek ninchen, Vrasagtok uysellie gondott reiank: Burya peternekis az mintt ő felsege atta az Donatiott, niocz haz heliett foglalt az eő hazahoz, kylen-czedik az kin az őnnőn haza uagion, tizedik az uaras kuta, mert aztis maganak $<$ foglalta, es $>$ tulaidonittia, az kik reia mennek mérnj ${ }^{4}$, nints oly iambor azzoni, kytt bestie kuruanak ne zyd.

Az Hew" palne hazahozis harom iobagi haz uagiō, negiedik, az Dérek haz, őtődik az hazhoz ualo pincze haz, az Zanto feödekettis birny ${ }^{5}$ akaria, mintt zintē az elött az mikor zolgalt tölle, Burya peteris azon keppen, Az haz utan ualo födek penig Nem az haz utan ualok hanem az kik zolgalnak tölle, Burya peter az ky haz heliekett az eő hazahoz foglalt, mindenikert iobagi lakott azon az elött.

Az vur Istennek keḡmes es io kedue legien vrasagtokuall mind feienkent. kegmes ualazt uarunk vrasagtoktoll.

Janos kouacs Tharczaly feö biro, Hiuseges Zolgalattiatt, aianlia vrasag-toknak mind az egez uarasuall Egetembe:

\footnotetext{
${ }^{3} \mathrm{Az} s$ javított betü.

${ }^{4} \mathrm{Az} e$ fölött valószínűleg dupla ékezet van.

${ }^{5}$ Az y i-ből javított betü.
} 


\section{Bury a peren the ro hasm

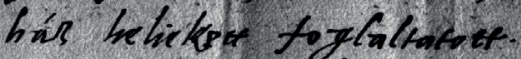

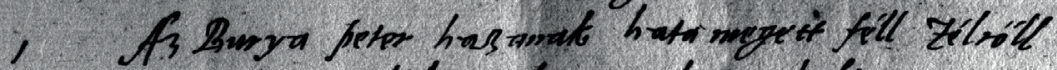

2 wayion thike shamas hala helie.

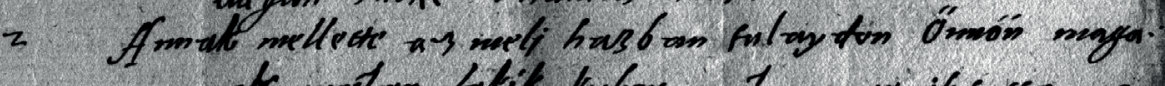

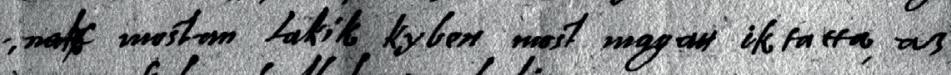
ines fola ball havera heles

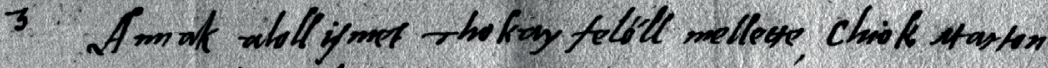
basubelier wose.

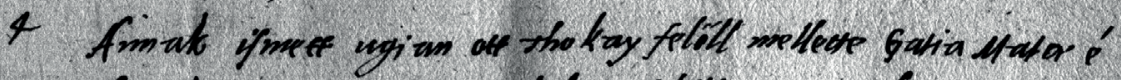

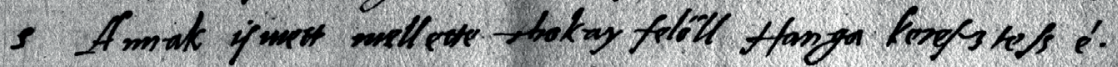

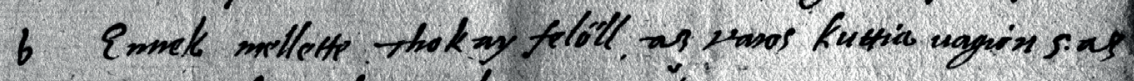

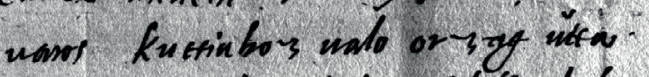

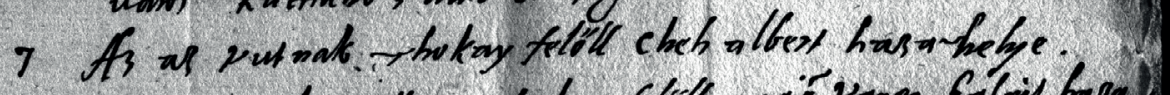

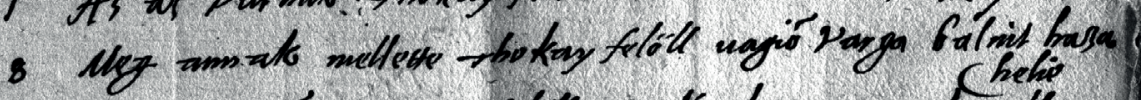

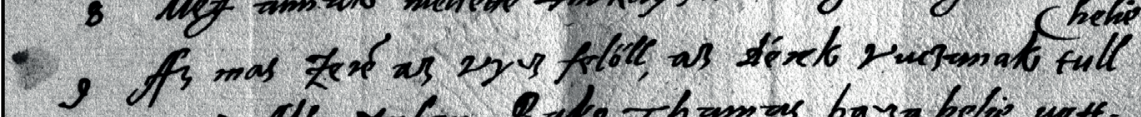
as flfo zaben, saleo thampos haya belas wott-

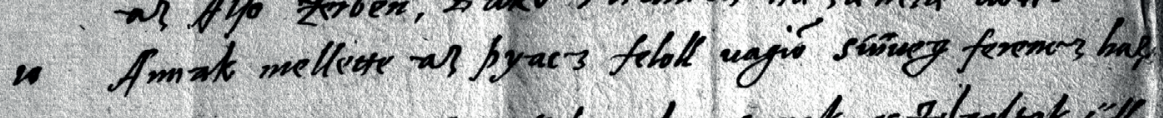

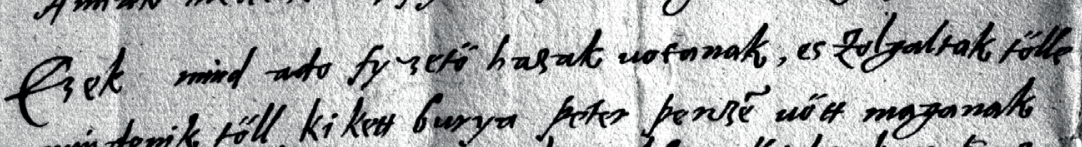

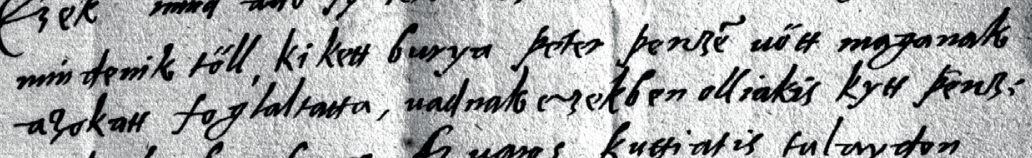

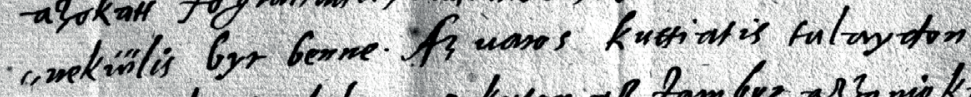
mganate foglalma, as kuton as fambre as o miokath

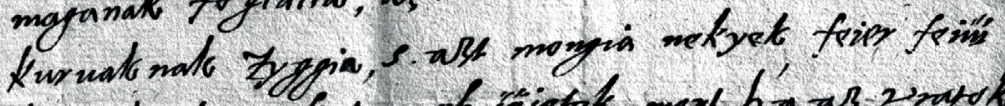

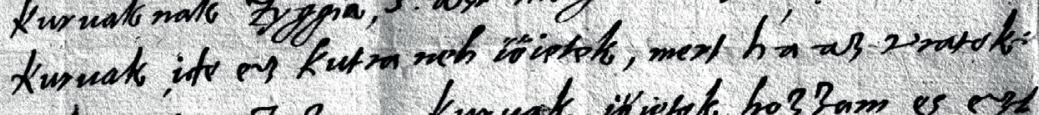

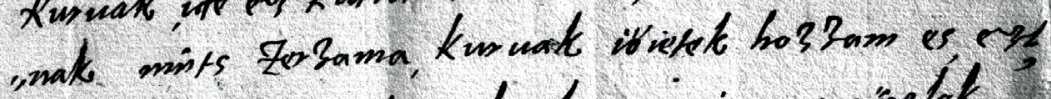
e3t, myuctern mindmintebrat, anagi mez nóslet bermekcker kurnak.

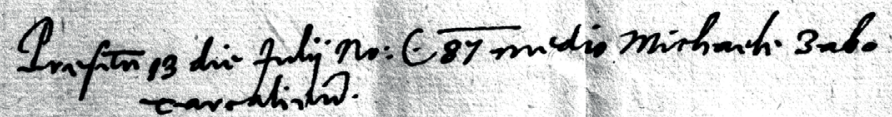


Burya peter az eő hazahoz meni ház heliekett foglaltatott.

1 Az Burya peter hazanak hata megett féll Zélrőll uagion Thöke Thamas haza helie.

2 Annak mellette az melj hazban tulaydon Őnnőn maga$-<$ nak $>$ mostan lakik kyben most magatt iktatta, az uott kola ${ }^{6}$ pall haza helie

3 Annak aloll ismet Thokay felöll mellette, Chiok Marton haza helie ŭott.

4 Annak ismett ugian ott Thokay felöll mellette Gatia Matae é

5 Annak ismett mellette Thokay felől Hanga keresztess é.

6 Ennek mellette Thokay felöll, az varos kuttia uagion s. az uaros kuttiahoz ualo orzag ŭtta.

$7 \mathrm{Az}$ az vutnak Thokay felöll cheh albert haza helye. ${ }^{7}$

8 Meg annak mellette Thokay felöll uagiō varga balint haza helie ${ }^{8}$

9 Az mas Zerē az vyz felöll, az Dérek vuczanak tull az Also Zerben, Bako Thamas haza helie uott.

10 Annak mellette az pyacz feloll uagiō Sw̋ueg ferencz haz

Ezek mind ado fyzető hazak uotanak, es Zolgaltak tőlle mindeniktöll, kikett burya peter penzē uött maganak azokatt foglaltatta, uadnak ezekben olliakis kytt penz- ${ }^{9}$ -nekw'lis byr benne. Az uaros kuttiatis tulaydon maganak foglalta, az kuton az Jambor azzoniokath kuruaknak Zyggia, s. azt mongia nekyek, feier feiw kuruak, ide ez kutra neh iöietek ${ }^{10}$, mert ha az vratok-nak nints Zerzama, kuruak iőietek hozzam es, ezt, ezt, myuelem mindniatoknak, ${ }^{11}$ auagj meg nőzlek bennetekett kuruak.

Praesentata ${ }^{12} 13$ die Julÿ Numero Christi $^{13} 87$ medio Michaele zabo Tarcaliensium.

\footnotetext{
${ }^{6} \mathrm{~A} k$ esetleg javított betü.

${ }^{7}$ A szókezdő $h$ megkezdett $z$-ből van javítva.

${ }^{8}$ A szó átmegy a következő sor végére, hovatartozására jelzés utal.

${ }^{9} \mathrm{Az} e$ fölötti vonás funkciója nem határozható meg.

${ }^{10} \mathrm{Az} i$-re is az ö ékezetei kerültek.

${ }^{11} \mathrm{Az} o$ javított betünek látszik.

${ }^{12}$ A sor elejétől más kéz írása.

${ }^{13}$ A dátumban szokatlan rövidítés feloldása nem kétségtelen.
} 


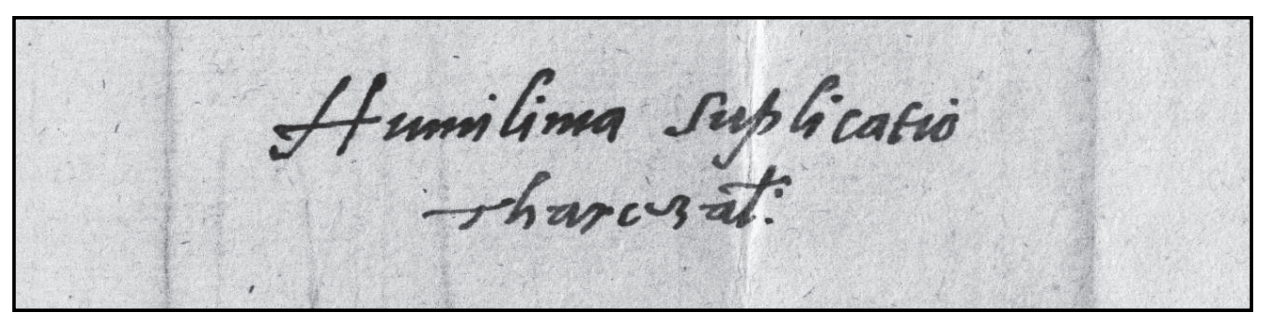

160 
Kívül:

Humilima Suplicatio

Tharczaliensium 


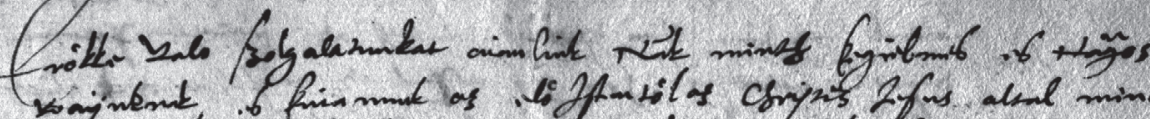

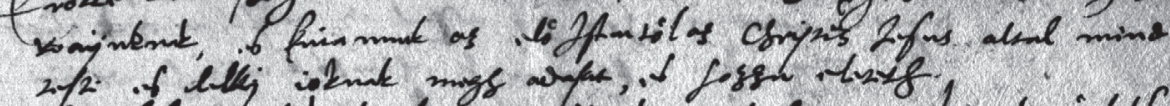

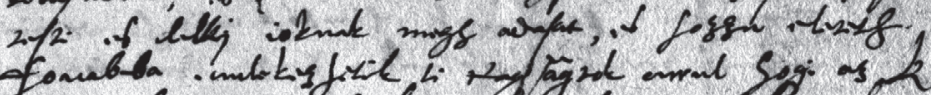

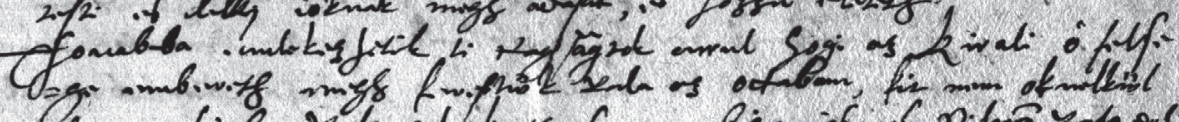

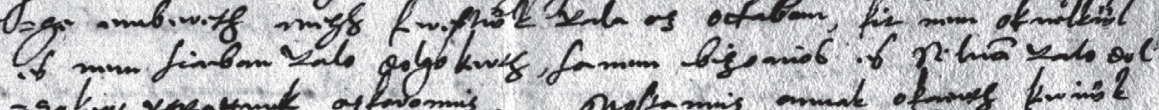

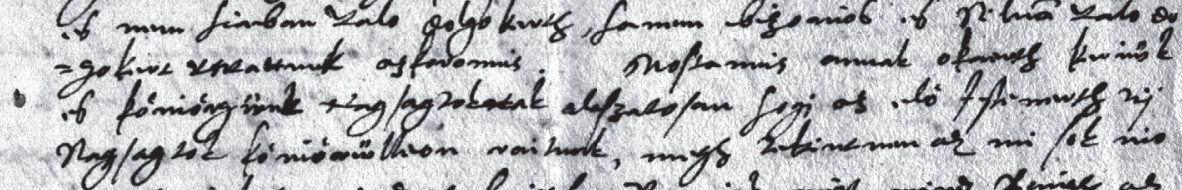

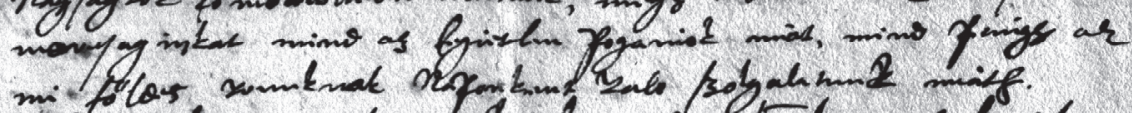

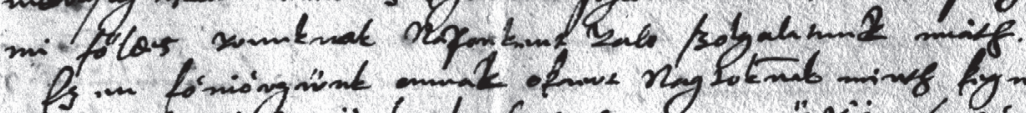

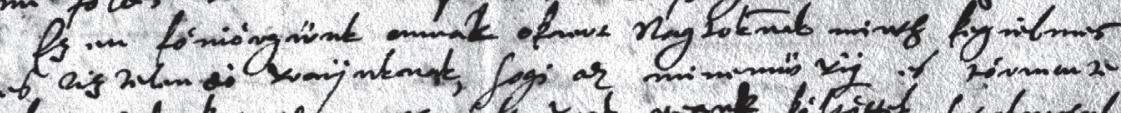

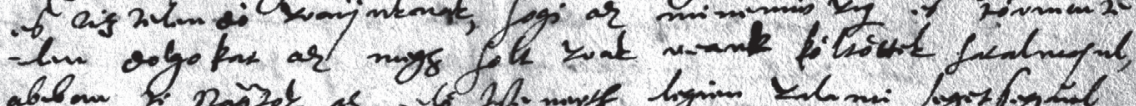

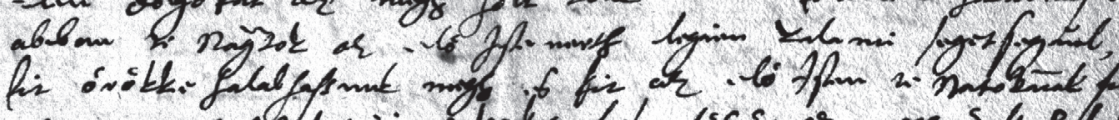

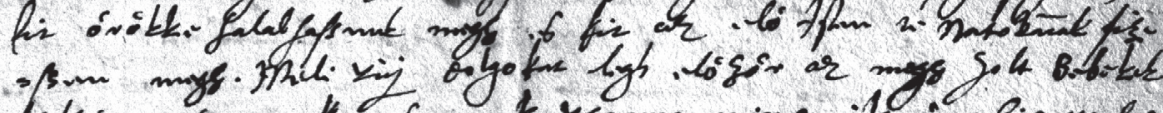

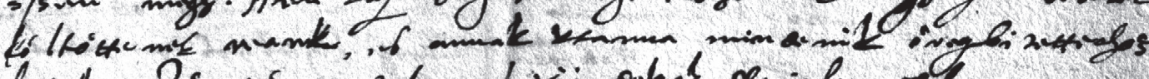

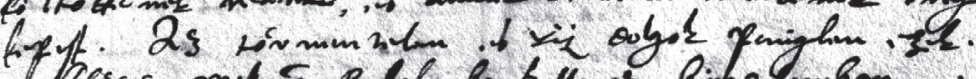

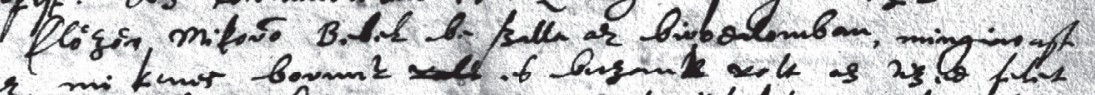

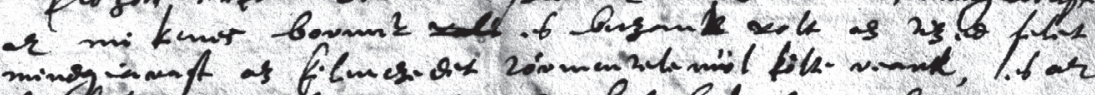

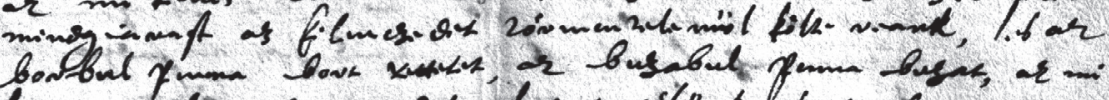

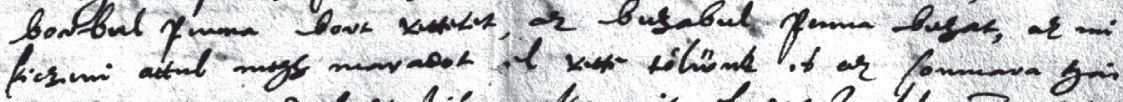

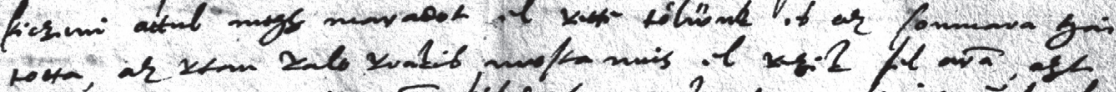

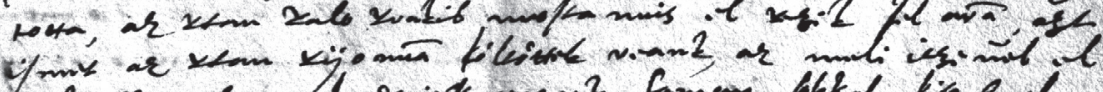

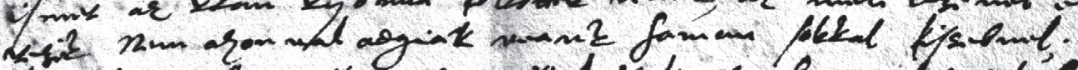

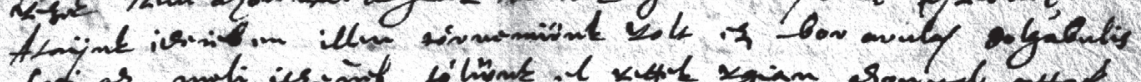

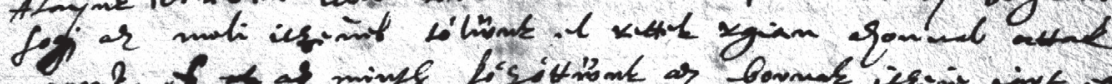

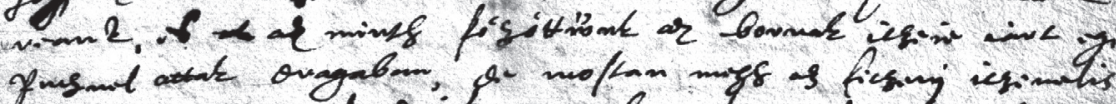

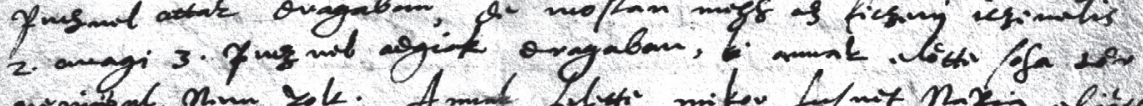

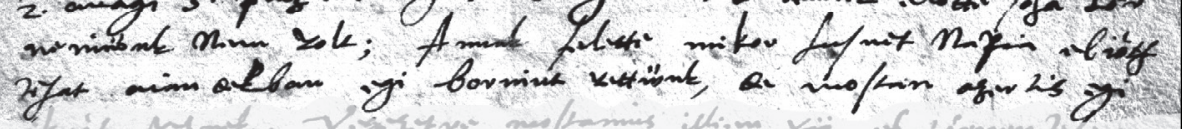




\section{I.28.}

Szádvár, 1588. VIII. 4. Szádvári jobbágyok levele.

Erôkke valo szolgalatunkat aianliuk Nak minth kegielmes es Nāgos vraÿnknak, es kiuanunk az eló Istento̊l az Christus Iesus altal mind testi es lelkj ioknak megh adasat, es hozzu eleteth.

Thouabba emlekezhetik ti Năgsagtok arrul hogi az kirali ò felse -ge embereth megh kerestw"k ${ }^{1}$ vala az octaban, kit nem oknelkw1 es nem hiaban valo dolgokerth, hanem bizonios es Nilua valo dol -gokert vntattunk ${ }^{2}$ azkoronnis. Mostannis annak okaerth keriwk es kơniơrgw"nk Nagsagtoknak ${ }^{3}$ alaszatosan hogi az elô Istenerth tÿ Nagsagtok kơniórẅlleon raitunk, megh tekintwen az mi sok nio morusaginkat ${ }^{4}$ mind az kegietlen poganiok miat, mind penigh az mi fôldes vrunknak Naponkent valo szolgalatunk miath.

Ezen ko̊nio̊rgw"nk annak okaert Nāgtoknak minth kegielmes es tiztelendô vraÿnknak, hogi az minemẅ vÿ es tồrwente -len dolgokat az megh holt vrak reank kôltoòttek hatalmasul, abban te Nāgtok az elö Istenerth legien valami segetsegŭel, kit o̊rókke halalhassunk megh es kit az elo̊ Isten te Natoknak fize -ssen megh. Meli vÿ dolgokat legh elözo̊r az megh holt Bebekek kôltôtttenek reank, es annak vtanna mindenik o̊regbitette ahoz kepest. Az tờruentelen es vÿ dolgok peniglen ezek.

Elơzoòr mikorō Bebek be szalla az birodalomban, mingiarast az mi keues borunk $<$ volt $>$ es buzank volt az tized felet mindgiarast az kilenczedet tờrwentelenw"l kòlte reank, es az borbul penna bort vettetet, az buzabul penna buzat, az mi kiczeni attul megh maradot el vette tơlw"nk es az sommara hai totta, az vtan valo vrakis mostannis el vezik fel arā, azt ismet az vtan vÿonnā kồlto̊ttek reank, az meli iczeŭel el vezik Nem azonual adgiak reank hanem sokkal kissebuel; Ataÿnk ideieben illen tơrueniw̋nk volt ez bor arulas dolgabulis hogj az meli iczeǔel tơlw"wnk el vettek vgian azonual attak reank, es <at> az minth kôzo̊ttw"nk az bornak iczeie iart egi penzuel attak dragaban, de mostan megh az kiczenj iczeuelis 2. auagi 3. penzuel adgiak dragaban, ki annak elötte soha tơr ueniwn'nk Nem volt; Annak felette mikor husuet Napia el iòth tehat aiandekban egi borniut vettw"nk, de mostan azertis egi

\footnotetext{
${ }^{1}$ Az $s$ alatt más betükezdet nyoma.

${ }^{2}$ Az első $n t$-böl javított betü.

${ }^{3}$ Az $n$ at betủkapcsolatból alakított betü.

${ }^{4} \mathrm{~A}$ szó második $o$-ján talán csak igazítás nyoma látszik.
} 


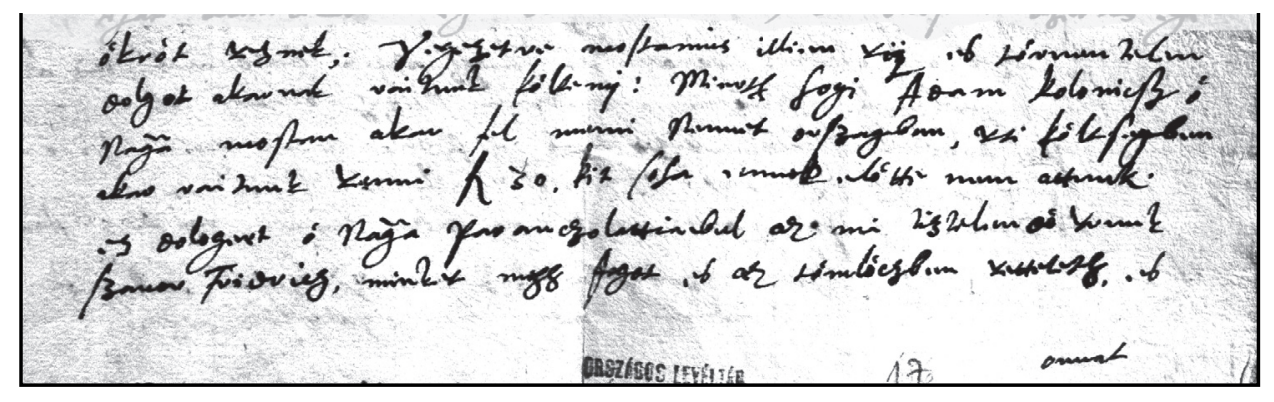

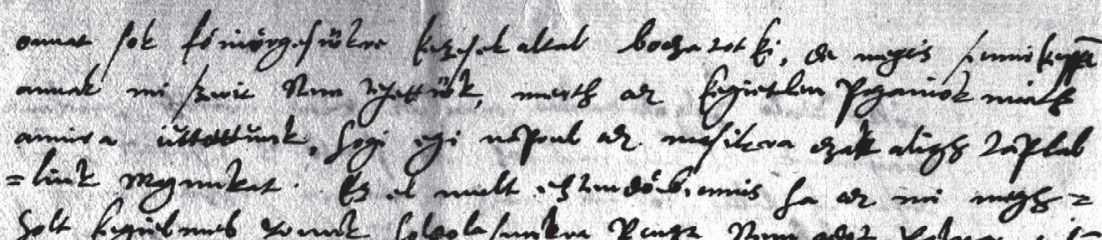

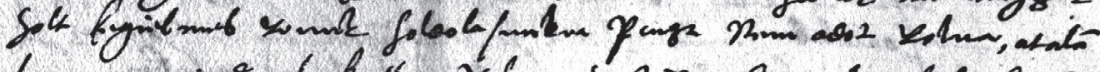

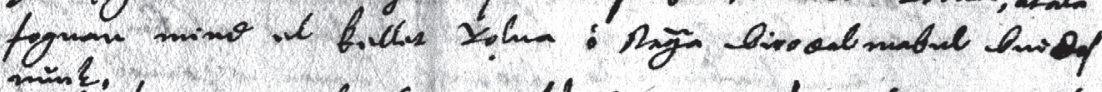

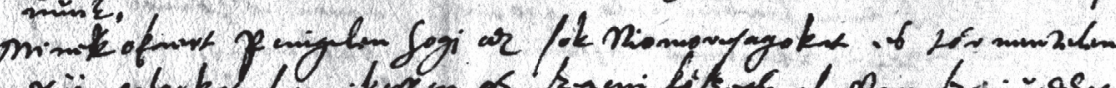

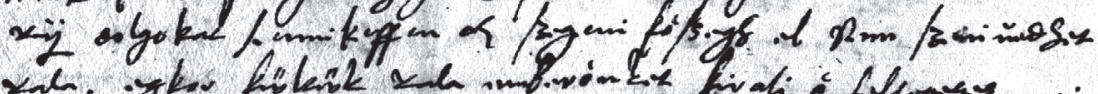

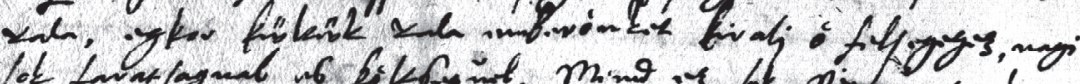

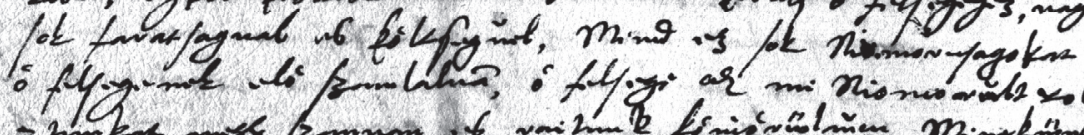

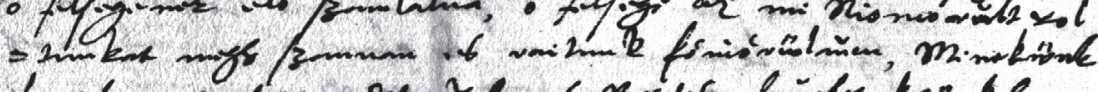

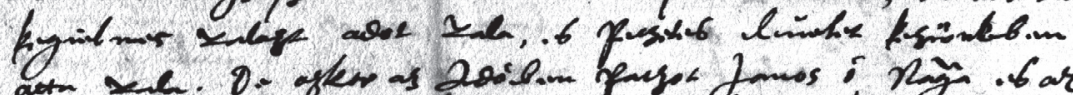

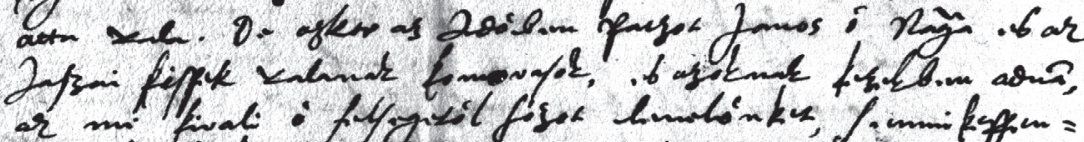

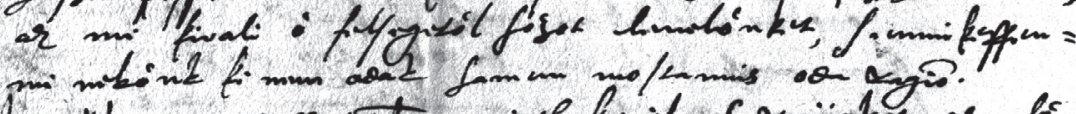

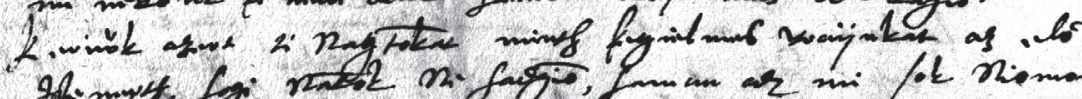

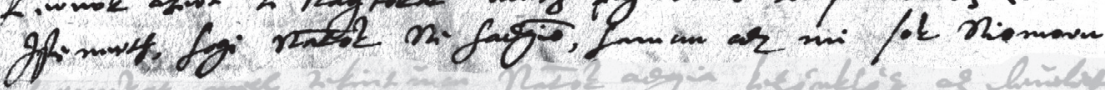


ókrôt veznek; Vegezetre mostannis illien vÿ ${ }^{5}$ es tơruentelen dolgot akarnak raitunk kồltenÿ: Mierth hogi Adam Kolonicsz o̊ Nāga mostan akar fel menni Nemet orszagban, vti kôltsegben akar raitunk venni florenos 30. kit soha ennek elotte nem attunk. ez dologert o̊ Nāga paranczolattiabul az mi tiztelendo̊ vrunk szauor Fridrich, minket megh fogot es az tòmlòczben vetteteth, es

onnat $^{6}$

onnat sok kôniỏrgesw̋nkre kezesek altal boczatot ki, de megis semmikeppe annak mi szerit Nem tehettwk, merth az kegietlen poganiok miath annira iŭtottŭnk, ${ }^{7}$ hogi egi naprul az masikra $\mathrm{czak}^{8}$ aligh taplal -liuk magunkat. Ez el mult eztendo̊bennis ha az mi meghholt kegielmes vrunk holdolasunkra penzt Nem adot volna, atala foguan mind el kellet volna o̊ Nāga birodalmabul buidos nŭnk, ${ }^{9}$

Minek okaert peniglen hogi az sok Niomorusagokat es torruentelen vÿ dolgokat semmikeppen az szegeni kôssegh el Nem szeniŭedhet vala, egkor kw̋ltw"k vala emberōnket kiralj ò felsegehez, nagi sok faratsagual es kooltsegŭel, Mind ez sok Niomorusagokat ${ }^{10}$ ò felsegenek elo̊ szamlaluā, o̊ felsege az mi Niomorŭlt ${ }^{11}$ vol -tunkat megh szanuan es raitunk kơniơrw"lŭen, Minekw"nk kegielmes valazt adot vala, es peczetes leǔelet kezw"nkben atta vala. De azkor az Idôben paczot Janos o̊ Nāga es az Jaszai pispek ${ }^{12}$ valanak komorasok, ${ }^{13}$ es azoknak kezekben adua, az mi kirali o̊ felsegetôl hozot leuelo̊nket, semmikeppenmi nekōnk ki nem adak hanem mostannis oda vagiō.

Keriw"k azert ti Nāgtokat minth kegielmes vraÿnkat az elò Istenerth, hogi Nātok Ne hadgiō, hanem az mi sok Niomoru

\footnotetext{
${ }^{5} \mathrm{Az} \ddot{y}$ alatt más betủkezdet nyoma látszik.

${ }^{6}$ Örszó.

${ }^{7}$ Az első $u$ második szára $t$-ből van javítva; az $o$ után felesleges betüszár látszik.

${ }^{8} \mathrm{~A} k$ javított betünek látszik.

${ }^{9} \mathrm{~A} d$ javított betünek látszik.

${ }^{10} \mathrm{Az} i$ után törölt betü.

${ }^{11} \mathrm{Az} \breve{u}$ feltehetőleg $w$-böl javított betü.

${ }^{12}$ A $p$ betü $k$-ból van javítva.

${ }^{13}$ A második $o$ talán javított betü.
} 


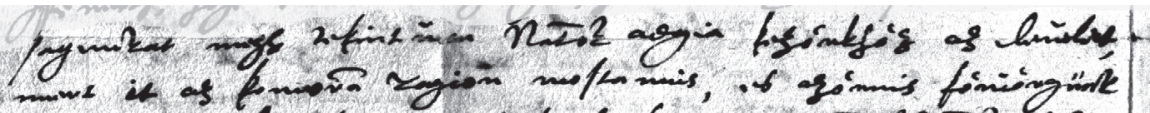

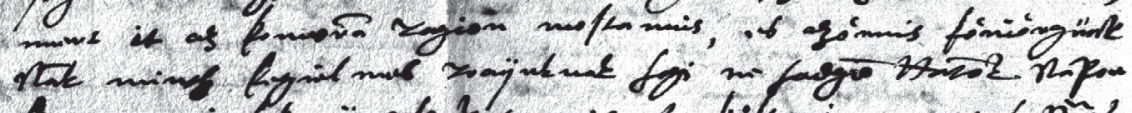

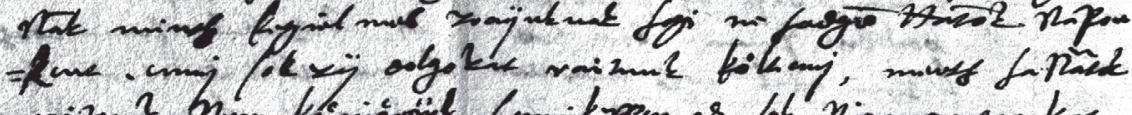

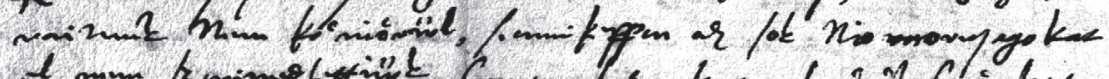

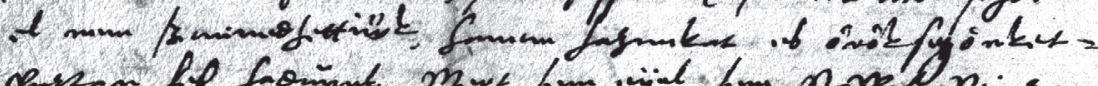

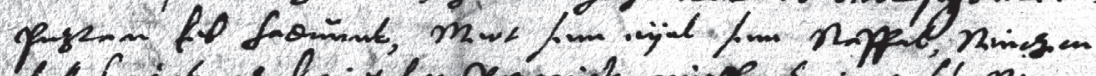

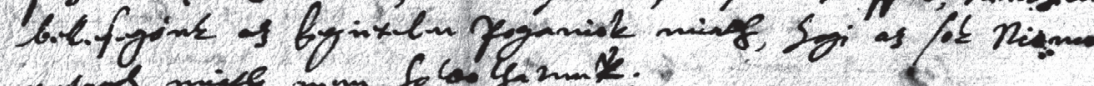

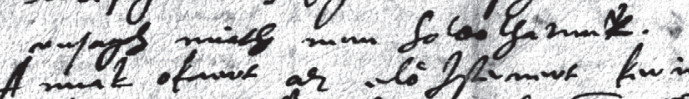

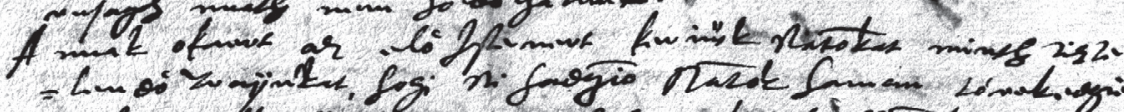

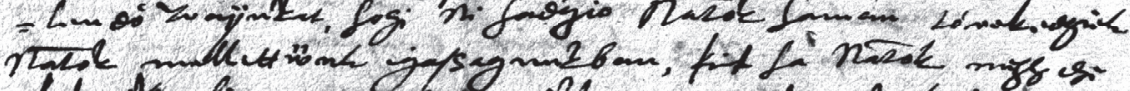

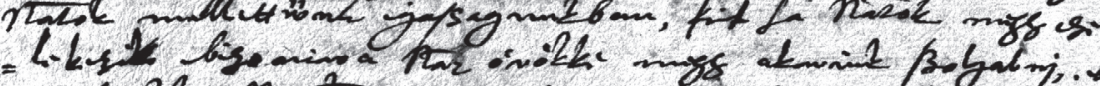

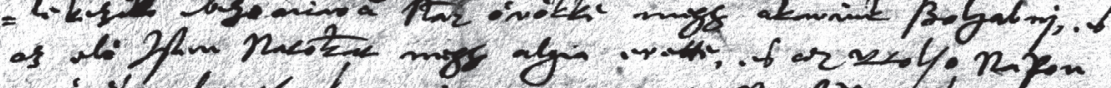

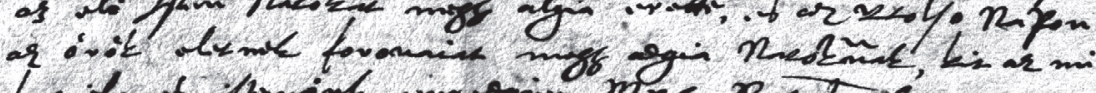

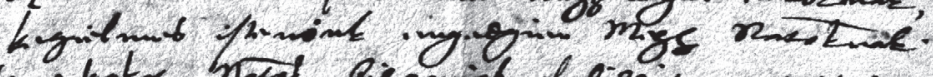

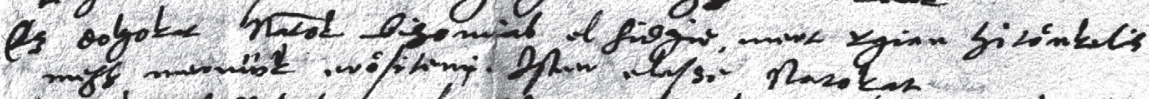

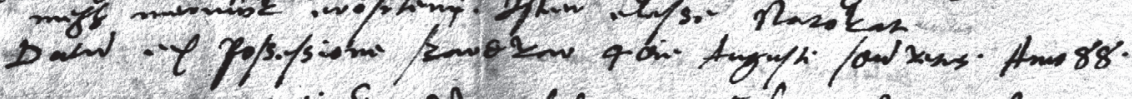

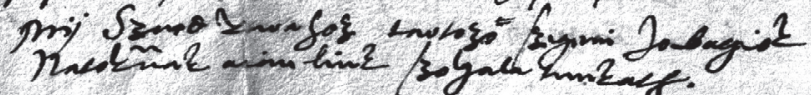

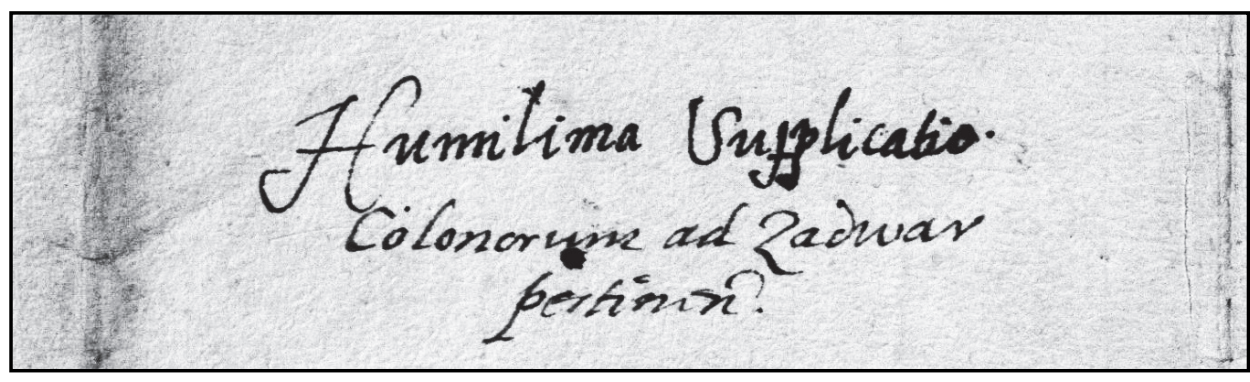


sagunkat megh tekintǔen Nătok adgia kezónkhơz az leŭelet, ${ }^{14}$ mert it az komora $\bar{a}^{15}$ vagion mostannis, es azônnis kôniơrgw"nk Nak minth kegielmes vraÿnknak hogi ne hadgiō Nătok Napon -kent ennj sok vÿ dolgokat raitunk kồtenj, merth ha Nātok raitunk Nem kôniơrw'l, semmikeppen az sok Niomorusagokat ${ }^{16}$ el nem szeniuedhettiwk, hanem hazunkat es ò ó kseegónket- ${ }^{17}$ puztan kel hadnŭnk, Mert sem eÿel sem Nappal, Ninczen bekesego̊nk az kegietelen poganiok miath, hogi az sok Niomo ${ }^{18}$ rusagh miath nem holdolhatunk. ${ }^{19}$

Annak okaert az elo̊ Istenert keriw"k Nātokat minth tizte -lendo̊ vraÿnkat, hogi Ne hadgiō Nātok hanem tờrekedgiek Nātok mellettwnnk igassagunkban, kit ha Nātok megh cze -lekezik bizoniara Nak oro orkke megh akariuk szolgalnj, es az elò Isten Nātokat megh algia erette, es az vtolso Napon az o̊ró̀ eletnek koronaiat megh adgia Natoknak, kit az mi kegielmes isteno̊nk engedgien Megh Natoknak.

Ez dolgokat Nātok bizonial el hidgie, mert vgian hitônkelis megh mernw"k erósitenj. ${ }^{20}$ Isten elesse Natokat

Datum ex possessione szardvar 4 die Augusti sard vetus Anno 88.

Mÿ Szard varahoz tartozo ${ }^{21}$ szegeni Jobagiok

Nātoknak aianliuk szolgalatunkath

Kívül más kezekkel irva:

Humillima Supplicatio

Colonorum $^{22}$ ad Zadwar

pertinentium.

\footnotetext{
${ }^{14} \mathrm{Az}$ utolsó $e$ esetleg javított betü.

${ }^{15}$ A második $o$ talán javított betü.

${ }^{16} \mathrm{Az} m$ betü $v+n$-böl lett kialakítva.

${ }^{17} \mathrm{~A} g$ javítottnak látszik. - A szó végén tévesen kitett elválasztójel van.

${ }^{18} \mathrm{Az}$ első $o$ esetleg javított betü.

${ }^{19} \mathrm{~A} k$ alatt más betükezdet nyoma.

${ }^{20} \mathrm{~A} j$ egy tévesen elkezdett betüből van kialakítva.

${ }^{21}$ A szóvégi $o$ fölül a levélíró törölte a mellékjelet.

${ }^{22} \mathrm{Az} u$ alatt más betüszár nyoma.
} 


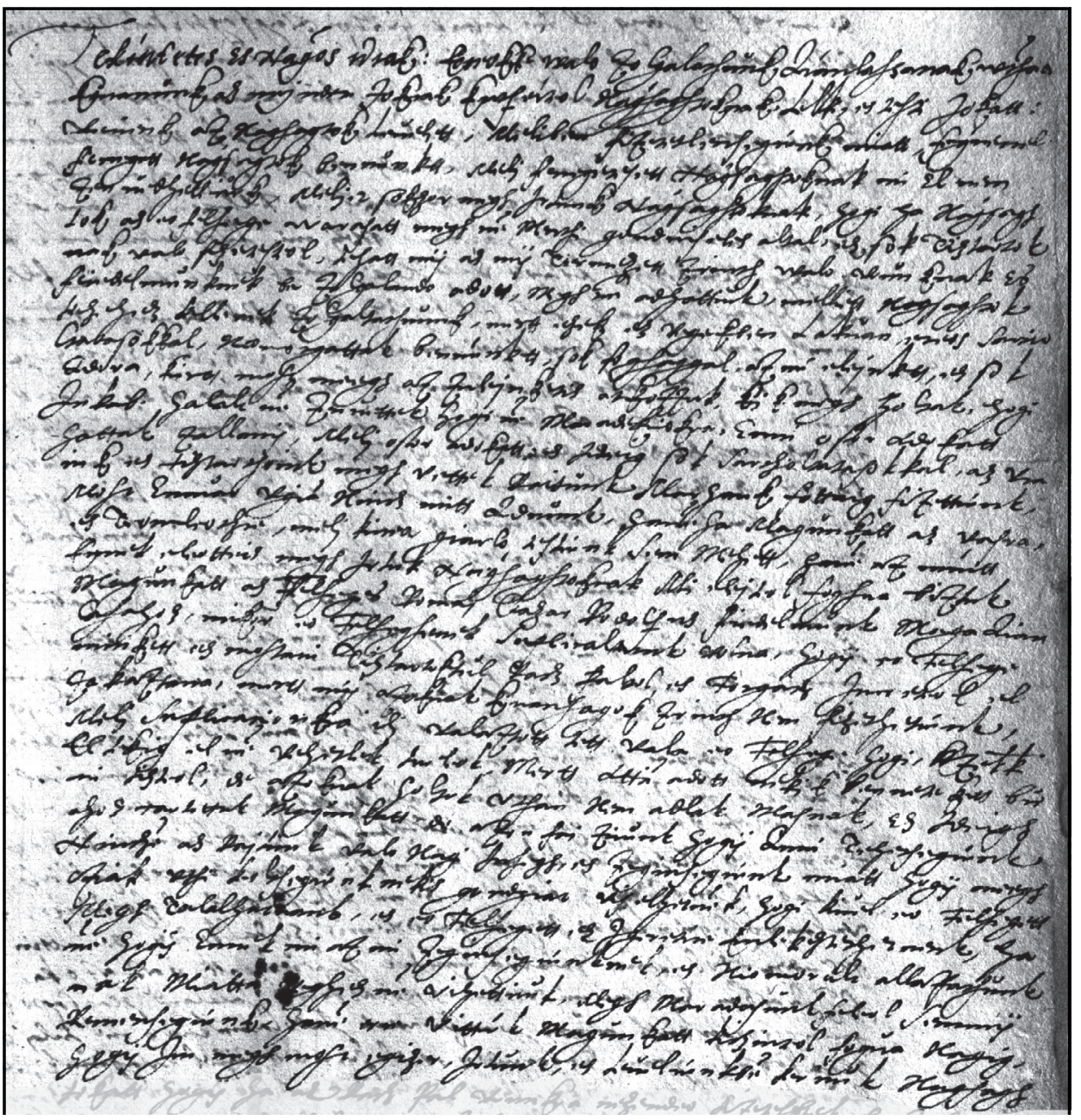


Maros, 1588. XI. 4. Marosi jobbágyok levele.

Tekintetes Es Nāgos wrak: Eoreokke walo zolgalathŭnk Aianlassanak wthāa kiuanŭnk az mÿnden Joknak kutfeitol Naǵsaghtoknak, Lelki es testi Jokatt: Veŭenk az nagsagtok Leǔelett, Meliben fizetetlensegẃnk miatt, feǵwerrel fenegett naǵsagtok bennŭnkett, Melj fenegetesett Naǵsagtoknak mi El nem zenŭedhettiw̌k, Meljet sokzor ${ }^{1}$ megh Irtŭnk Naǵsaghtoknak, hogi ha Naǵsagh tok az eo felsege warasatt megh ne Menthi gonduiseles altal, ez sok Tiztartok nak valo fizetestol, tehatt mÿ az mÿ Termezett zerinth walo vrŭnknak es feiedelmŭnknek be zolgalando adott, Megh nē adhattiŭk, melliett nagsaghtok kezehez kellenek zolgaltathnŭnk, mertt ezek ez vegekben Lakŭan ereos sarcio ltatasokkal, niomorgattak bennŭnkett, sok fogsaggal, az mi elejnkett, ez sok Adora, kiertt most meegh az zulejnketis atkozzuk, kik megh holtak, hogi Inkab halalt ne zenŭettek hogi nē Maradekiokra, Enni ostor adokatt hattak zallanÿ, Melj ostor adokatt ez Ideig sok sarczioltatasokkal, ${ }^{2}$ az Vra ink es tiztarthoink megh vettek Raitŭnk Marhank fottaig fizettẃnk, Most Emmār vgiā Nincz mitt Adnŭnk, hanē ha Magŭnkatt az vasra, es Teomleoczre, melj kinra giarlo testẃnk Sem Mehett, hanē az mintt Ennek eleotteis megh Irtuk Naigsaghtoknak Mi elejteol foghua biztuk Magŭnkatt az Felseges Romaj Ciazar Rodolfus feiedelmŭnk Maga Aian lasahoz, mikor eo Felseghenek Suplicaltunk ${ }^{3}$ volna, hogÿ eo Felsege minkett ez mostani Tiztartoktŭl Racz Paltol, es Forgacz ${ }^{4}$ Imreteol el zakaztana, mertt mÿ azoknak kjuansagok zerinth Nem fizethetẃnk, Melj Suplicacionkra ilj valaztott tett vala eo Felsege hogi, Ezekk ${ }^{5}$ Eltekig el nē vehetlek twleok, Mertt Attiā adott nekik bennetekett bir ni tizteol, de azoknak holtok vthan Nem adlak Masnak, Ez Ideigh ahoz Tartottuk Magŭnkatt de azon fai ziuŭnk hogÿ Anni Tehetsegẃnk Ninczē az Rajtŭnk valo Nagi Insegh, es zeginsegẃnk miatt hogÿ meegh cziak vthi keoltsegẃnknekis gondgiat viselhetnek, hogi kiŭel eo Felsegett Megh Talalhatnank, es eo Felsegett, ez Igeretire Emlekeztethetnenk, ha ne hogÿ Ennek mi az mi zeginsegŭnknek, es Niomorult allapathŭnk nak Miatta veghez nē vihettiŭk, Megh Maradasŭnk feleol semmÿ Remensegẃnk, hanē erre vittẃk Magŭnkatt kiczinteol fogŭa Nagig, hogÿ Im megh most egizer, Irtŭnk, es Leŭelẃnkbē keriŭk Nagsagh

\footnotetext{
${ }^{1} \mathrm{~A} k$ feltehetően $z$-nek indult.

${ }^{2}$ Az $i$-t csak egy pont jelzi.

${ }^{3} \mathrm{~A}$ tu betűkapcsolat javítottnak látszik.

${ }^{4} \mathrm{~A} z$ javított betü.

${ }^{5}$ Az E talán javított betü.
} 


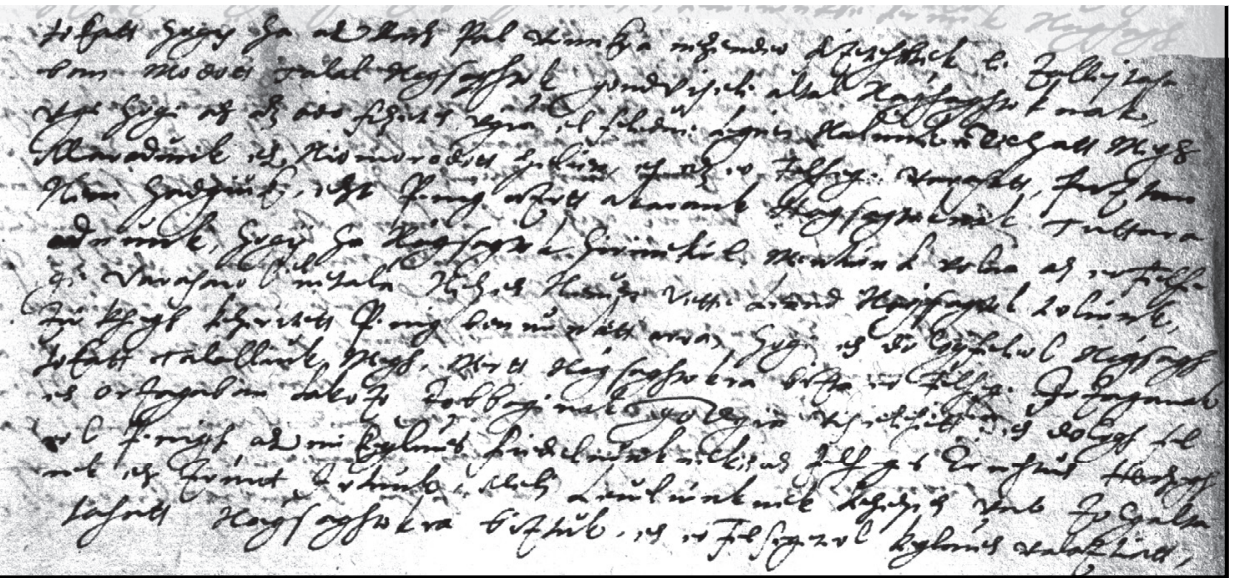

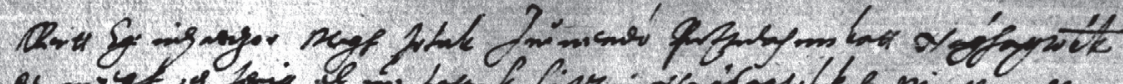

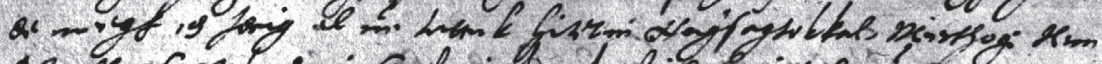

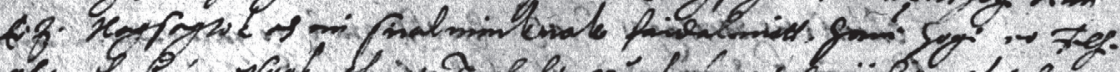

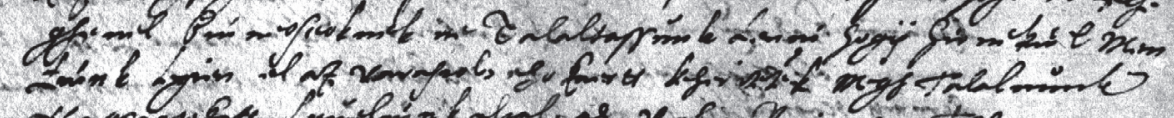

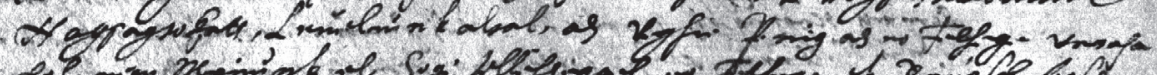

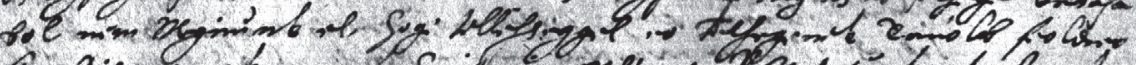

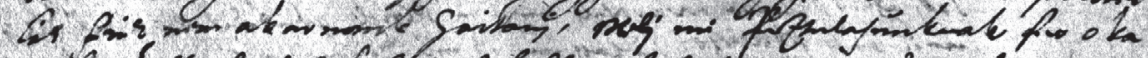

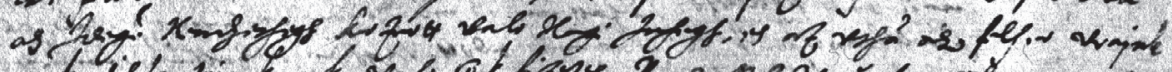

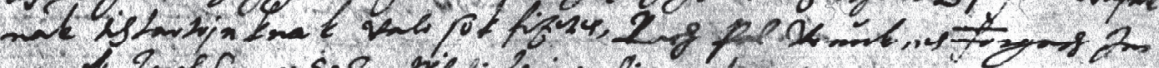

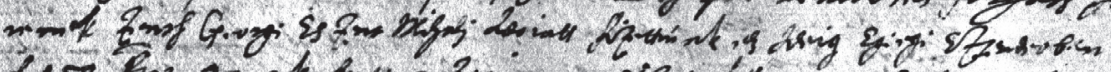

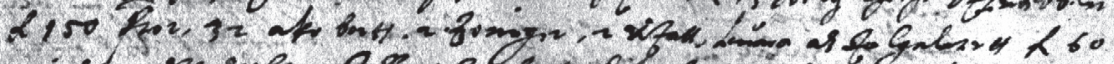

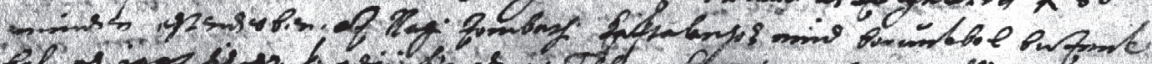

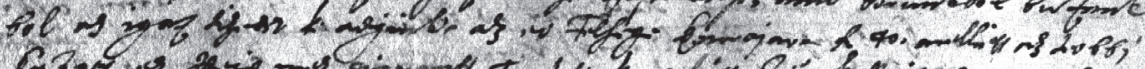

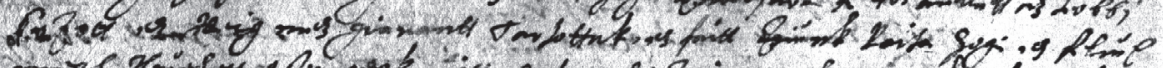

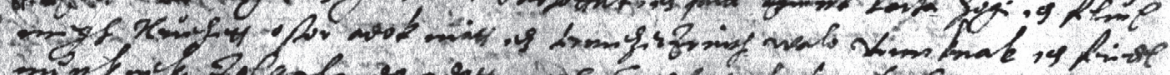

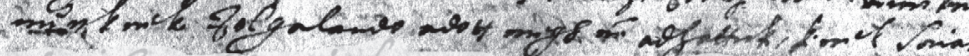


tokatt hogÿ ha az Racz Pal vrunkra nezendeo fizetesnek ${ }^{6}$ le zallejtasa ban Modott Talal Nagsaghtok gondvisele altal Naǵsaghtoknak, vgi hogi az az ado fizetes vgiā el feledue Legien Nalŭnk Tehatt ${ }^{7}$ Megh Maradŭnk ez niomorodott helien, es az eo Felsege varasatt, puztan Nem hadgiŭk, ezt Penig azertt akarank Nagsagtoknak Tuttara adnŭnk, hogÿ ha Naǵsagtok hirinekẃl Mentẃnk volna az eo Felse ge varasarol $\mathrm{el}^{8}$ netalā Nehez Neŭen vette Leend Naǵsagtok teolẃnk, zẃksegh kezeritett Penig bennŭnkett arra, hogi ez dologfeleol Naǵsagh tokatt Talalliŭk Megh, Mertt Naǵsaghtokra bizta eo Felsege Jozaganak es orzagaban Lakozo Jobbaginak gōdgia viselesett ez dologh fel eol Penigh az mi keḡlmes feiedelmŭnknekis az felseges Ernestŭs Herczegh nek ez zerintt Irtŭnk, Melj Leŭelẃnknek kezehez valo zolgalta tasatt Naǵsaghtokra biztŭk, es eo Felsegeteol keḡlmes valaztiatt,

Mertt Egi nihanzor ${ }^{9}$ Megh Irtuk Jwǔendó Puztulasunkatt Naǵsagtok $\bar{k}$ de meegh ez Ideig el ne tuttuk hitetni Naǵsagtokkal, Mierthogi Nem Ereze Nagsagtok az mi siralminknak faidalmitt, hane hogi eo Felse ghenel bẃneoseoknek ne Talaltassŭnk Lenni hogÿ hir nekẃl Men tẃnk Legien el az varasrol, ezokaertt kezeritetek Megh Talalnŭnk Nagsagtokatt, Leǔelẃnk altal, az veghre Penig az eo Felsege varasa bol nem Megiẃnk el, hogi telliesseggel eo Felsegenek Tauolab feoldero lis $[\ldots]^{10}$ nem akarnank haitanj, melj mi Pwztulasŭnknak feo oka az Idege Nemzetsegh keozeott valo Nagi Insegh, es az vthā az felseo vrajnk nak tiztartojnknak valo sok fizetes, Racz Pal Vrŭnk, es Forgacz ${ }^{11} \mathrm{Im}$ renek zenth Georgi Es zent Mihalj Adoiatt fizettẃnk ez Ideig Egiegi Eztendeoben R 150 ftot, 32 ako bortt .2. zonieget, 2 vizatt, Leŭara az Zolgalatertt R 60 minden eztendeoben, az Nagi zombathi kaptalanhoz ${ }^{12}$ mind borŭnkbol buzank bol az igaz tizedet ${ }^{13} \mathrm{ki}$ adgiuk, ${ }^{14}$ az eo Felsege komrajara $\mathrm{R}$ 40. melliett az teobbj keozeott ez Ideig mez gianantt Tartottuk, es faitt ziẃnk Raita hogi es felẃl megh Neŭezett ostor adok miatt ez termezetzerinth walo vrunknak es feiedel mẃnknek zolgalando adott megh nē adhattuk, kinek Saiati vagiẃnk

\footnotetext{
${ }^{6} \mathrm{Az} n$ javított betü.

${ }^{7}$ A szókezdet és az elötte levő betümaradvány azt mutatja, hogy a levélíró egy másik szót kezdett el.

${ }^{8}$ A szó interlineáris betoldás.

${ }^{9}$ A második $n$ javított betü.

${ }^{10}$ A szó olvasata bizonytalan.

${ }^{11}$ A $F f$-böl van javítva.

${ }^{12} \mathrm{~A} p$ javított betü.

${ }^{13} \mathrm{~A} d$ talán javított betü.

${ }^{14} \mathrm{Az} u$ javított betủnek látszik.
} 


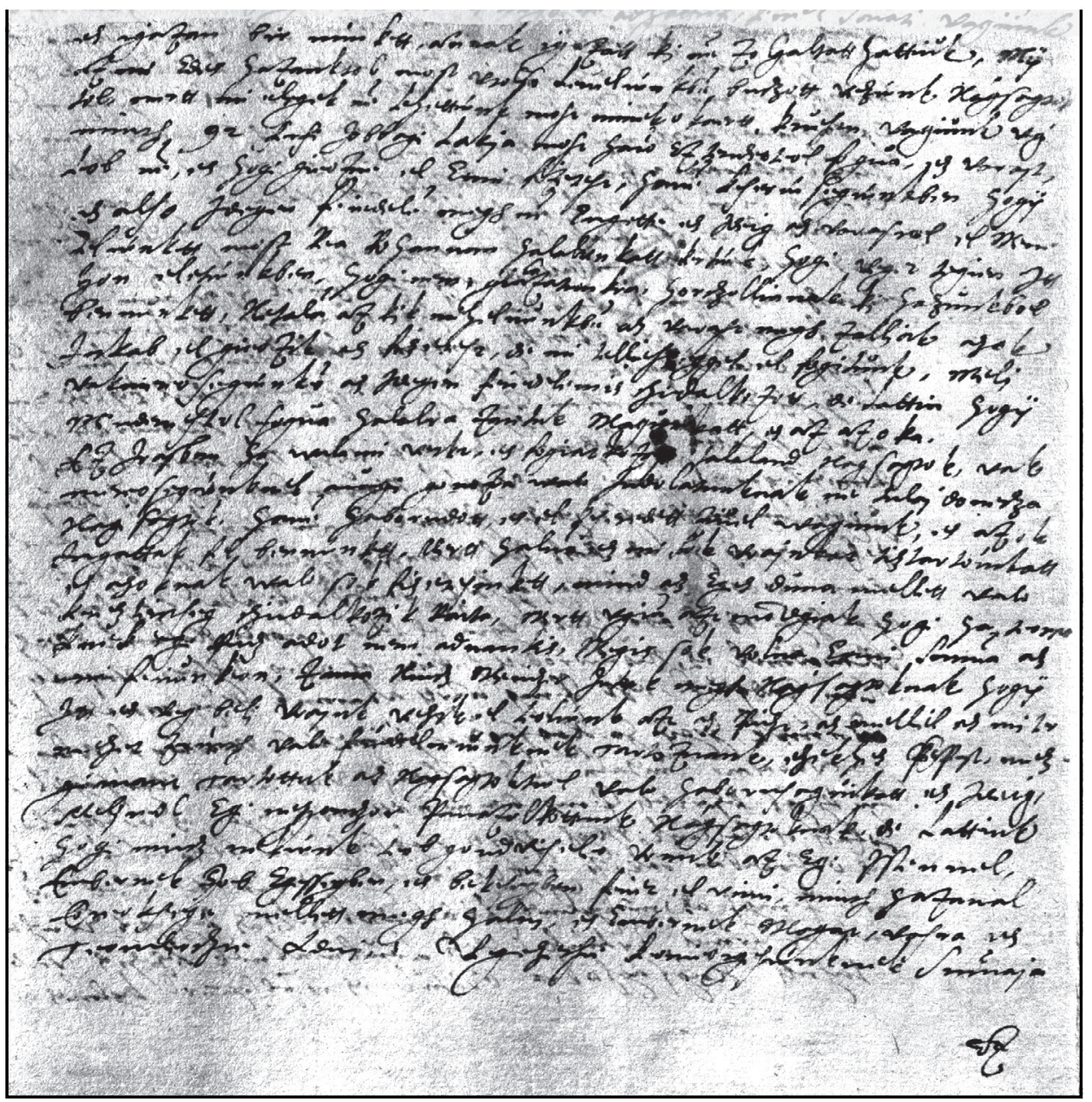


es igazan bir minkett, annak ${ }^{15}$ igazatt kj ne zolgaltatthattiŭk, Mÿ az mi Edes hazanktol most vtolso Leǔelẃnkbē bwczott vezẃnk Naǵsagtok tol, mertt mi elegek nē lehettẃnk most minekokaertt, keŭesen vagiŭnk vǵ minth 92 ferfi Jobbagi Lakja most harō Eztendeoteol fogŭa, ez Varast, teob nē, es hogi gieozne el Enni fizetest, hanē keserẃsegẃnkben hogÿ ez also Idegen feiedelē megh ne Engette ez Ideig az varasrol el Mene telẃnkett, most Rea Rohanuan halalŭnkatt kertẃk, hogi veget tegien Itt hon eletẃnkben, hogi nem gialazatwnkra, ${ }^{16}$ horczollianak ki hazŭnkbol bennŭnket, Netalā az kik mi heliẃnkbē az varast megh zalliak azok Inkab el gieozik az fizetest, de mi telliesseggel el fogitŭnk, melj vakmereosegẃnkeō az Idegen feiedelemis cziudalkozott, de Lattia hogÿ Mindenesteol fogŭa halalra zantuk Magŭnkatt, es az az oka.

Ez Irasban ha walami vetket, es fogiatkozast talaland nagsagtok, vak mereosegẃnknek aŭagi gonozra walo Indolatunknak ne tulajdonecza Nagisagtok, hanē haborudott, es el keseredett ziŭel wagiunk, es azok Ingattak fel bennv́nkett, Mertt haluā ez mi sok vrajnkat tiztartoinkatt es azoknak walo sok fizetesinkett, mind az Egez dŭna mellett valo kereztienseg chiudalkozik Raita, mertt vgiā azt mōdgiak hogi ha teorreo knek egi pinz adot nem adnankis, Megis sok volna Enni Somma az mi feiŭnkeon, zama Nincz Menizer Irtwk ${ }^{17}$ megh Naǵsagtoknak hogÿ Itt ez veg beli vrajnk vezik el teolẃnk azt az pinzt, az melliel az mi ter mezet zerinth valo feiedelmẃnknek Tartoznank, ezekhez kepest, ${ }^{18}$ mez gianant Tartottuk az Nagsagtoktwl valo haborusaginkatt ez Ideig, Meljreol Egi nehanzor Panazolkottunk Naǵsagtoknak, de Lattiuk hogi nincz nekẃnk teob gondviseleo vrŭnk az Egi Istennel, Embernek Job ${ }^{19}$ Egessegben, es bekesegben feiet el vinni, minth hazanal Eoreoksege mellett megh halnj, es Embernek Magat, vasra es teomleoczre Adnj, Vegezethre keonieorgesẃnknek Sumaja

$$
\mathrm{ez}^{20}
$$

\footnotetext{
${ }^{15} \mathrm{Az}$ a után talán más betü indul.

${ }^{16} \mathrm{~A}$ la betükapcsolat interlineáris betoldás.

${ }^{17} \mathrm{~A} w$ formája nem egyértelmủ.

${ }^{18}$ A $k f$-ből javított betü.

${ }^{19} \mathrm{~A} J$ javított betü.

${ }^{20}$ A szó pozíciója őrszóra enged következtetni, azonban a levélíró a következő lapon a szó megismétlése nélkül folytatja a szöveget.
} 

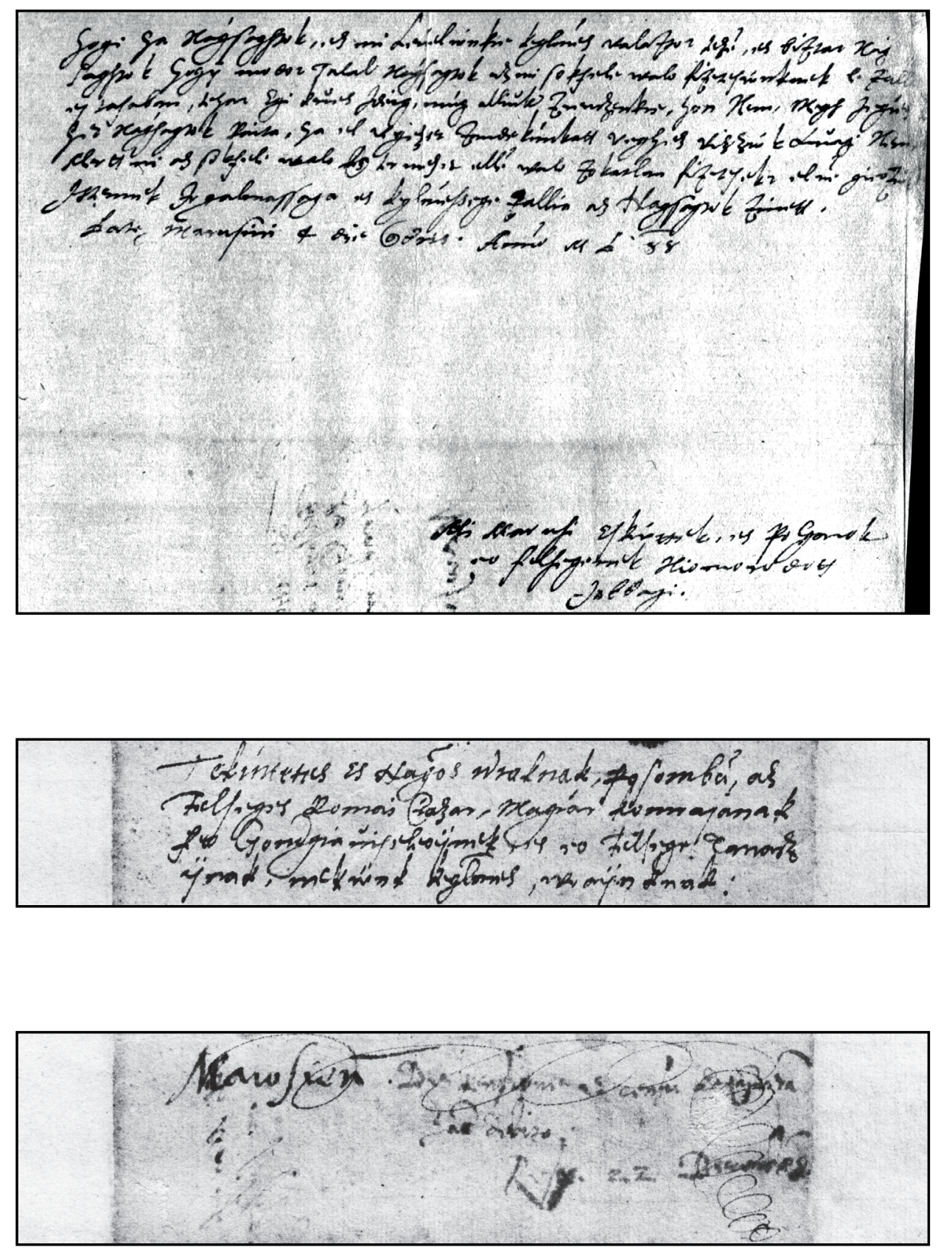

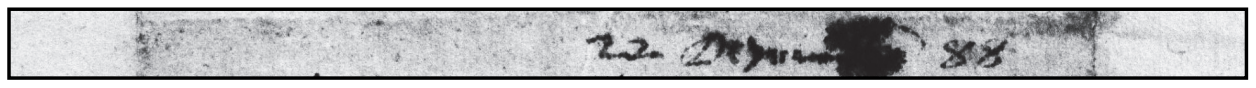


hogi ha naǵsaghtok, ez mi Leŭelẃnkre keḡlmes valaztot tezē, es biztat Naǵ saghtok hogÿ modot Talal naǵsagtok az mi sokfele walo fizetesẃnknek le zall ejtasaban, tehat Egi keŭes Ideig, mig alliŭk zerenczenkre, hon Nem, megh Jegie[.] ${ }^{21}$ het naǵsagtok Raita, ha el vegezet zandekúnkatt veghez vizzẃk Aŭagi Nem, Mertt mi az sokfele walo ${ }^{22} \mathrm{Es}^{23}$ termezet elle walo zokatlan fizeteseket el ne gieozẃk Istennek Irgalmassaga es keḡlmessege zallia az Nagsagtok ziuett.

datae Marusini 4 die 9bris. Annorum MD 88

Mi Marusi Eskẃttek, es Polgarok eo felsegenek Niomorodott Jobbagi.

Kívül:

Tekintetes es Nāgos Wraknak, Posombā, az Felseges Romai Ciazar, Magiar komrajanak feo Gondgia ŭiseleoÿnek, es eo Felsege Tanacz ÿnak, nekẃnk keḡlmes, wraÿnknak:

Más kézzel irva:

Marosienses. Die pensione et censu [...]

[...] debito.

Responsum $^{24} 22$ Decembris

22. Decembris 88

\footnotetext{
${ }^{21}$ A szó végén világosan ki nem vehető betű esetleg $z$ lehetett.

${ }^{22} \mathrm{~A} w$ javított betű.

${ }^{23} \mathrm{Az} E$ talán javított betü.

${ }^{24} \mathrm{~A}$ rövidítés többféle feloldása is lehetséges.
} 
E 254 - 1589. júl. No. 45.

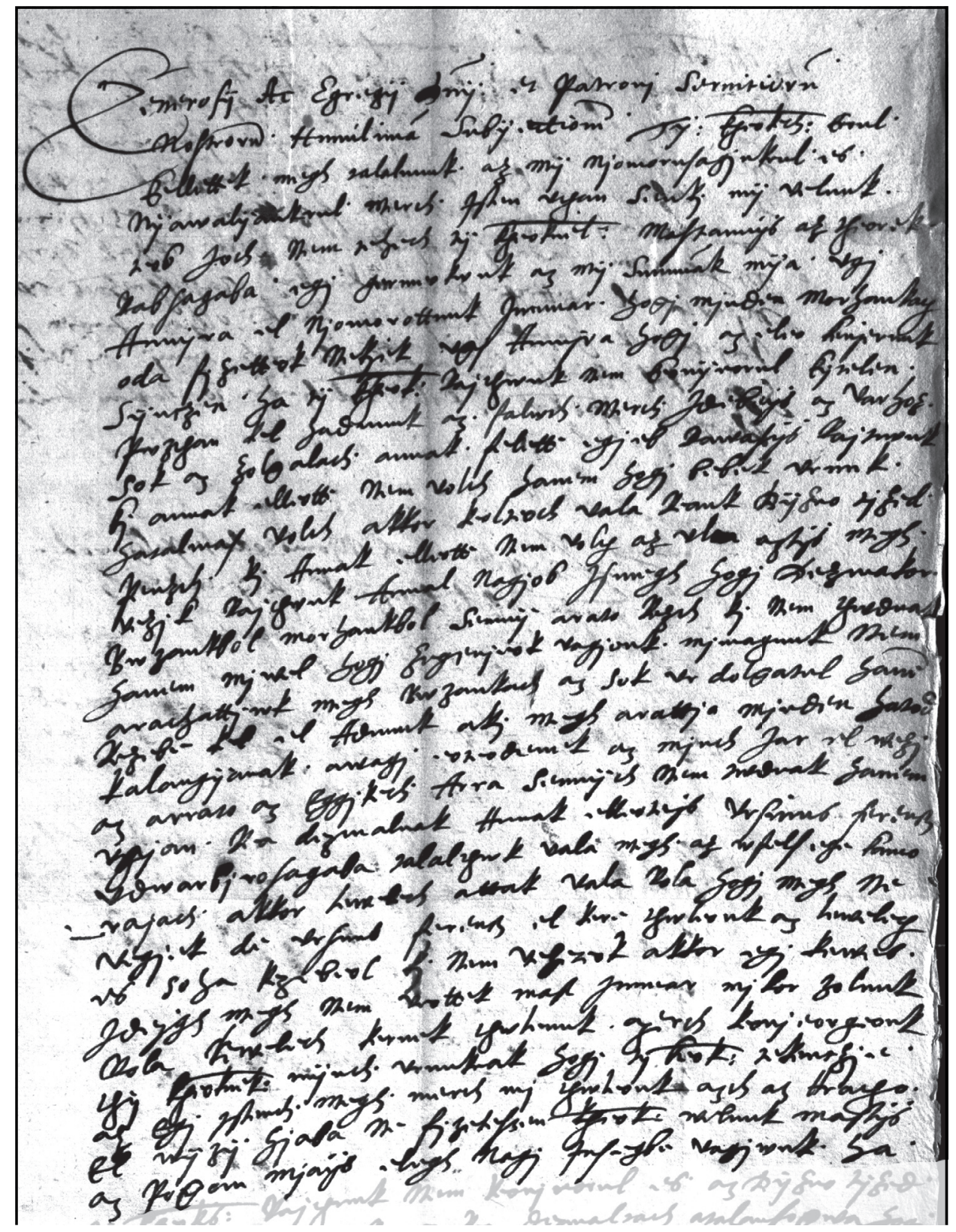


Edelény, 1589. VII. 10. edelényi jobbágyok levele.

Generosÿ Ac Egregÿ Dominÿ ${ }^{1}$ et Patronj Seruitiorum Nostroru $m \cdot$ Humilimam Subÿectione $m \cdot$ Tÿ ${ }^{2}$ kgeoketh Errul · kellettek · megh talalnunk · az mÿ njomorusagjnkrul · es · Nÿawalÿankrul $\cdot$ merth $\cdot$ Isten vthan senkj mÿ velunk · teob Joth $<$.> Nem teheth tÿ kgeoknel Mastannÿs az theorek · Rabsagaba · egj germeokvnk az mÿ summāk mÿa $\cdot$ vgj · Annÿra el Njomorottunk Immar · hogj mjnden morhankath oda fjzetteok Nekjek vgj Annÿra hogj az eleo kenjerunk Sÿnczen · ha tÿ kgeok Rajthwnk nem keonÿeorul kjtelen · Pwzthan kel hadnunk az · falwth · merth · Idebeÿs az Varhoz · Sok az zolgalath · annak · felette egjeb Rawasÿs Rajtwnk $\mathrm{kj}$ annak elleotte Nem volth hanem hogj bebek vrunk . hatalmas volth akkor keolteoth vala Reank Dÿzno tjzed · Penzth · kj Annak elleotte Nem volth az vl... ${ }^{3}$ aztÿs megh · vezjk Rajthwnk Annal Nagjob Ismegh hogj Dezmakor • Bwzankbol morhankbol semmÿ arato Rezth kj Nem thwdnak hanem mjwel hogj zegenjeok vagjonk · mjmagunk Nem arathattjwk megh Bwzankath az sok vr dolgatul hane Rezebe kel el Adnunk akj megh arattja mjnden hatod kalangÿanak · awagj eoteodenek az mjnth Jar el wezj az arrato az Eggjketh · Arra semmÿth Nem twdnak hanem vgÿan $^{4}$ - Rea dezmalnak Annak elleotejs Vrsinus ferencz vdwarbjrosagaba talalthwk vala megh $\cdot$ az wfelsege kamo rajath · akkor leweleth attak vala Rola hogj megh $\mathrm{Ne}$ vegjek de vrsinus ferencz el kere thwleonk az leweleth es soha kezebeol kj Nem veheteok akkor egj kewes · Idejgh megh Nem veottek mast Immar mjkor zolunk Rola leweleth ${ }^{5}$ kernek thwleunk · azerth keonjeorgeonk thÿ kgeoknek mÿnth · vrunknak hogj tÿ keok tekenczje · az egj Istenth - megh · merth mj thwleonk azth az Aratho · El wÿzÿ hjaba Ne fjzetessen kgeok welunk mastÿs az pogan mjaÿs elegh nagj Insegbe vagjwnk · ha ·

\footnotetext{
${ }^{1} \mathrm{~A} D$-n talán javítás nyoma látszik.

${ }^{2}$ A rövidítéseket nemcsak a szó fölötti vonás, hanem az utána (itt: elötte és utána) álló kettőspont is jelöli. Az átírásban egyszeres jelzést alkalmazunk.

${ }^{3} \mathrm{Az}$ utolsó két betü olvasata tintafolt miatt bizonytalan (a levélíró feltehetően után-t akart írni).

${ }^{4} \mathrm{~A} g$ javított betü.

${ }^{5}$ Az első $l$ más betünek indult.
} 


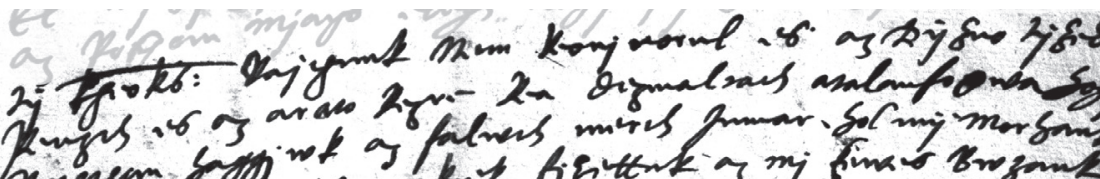

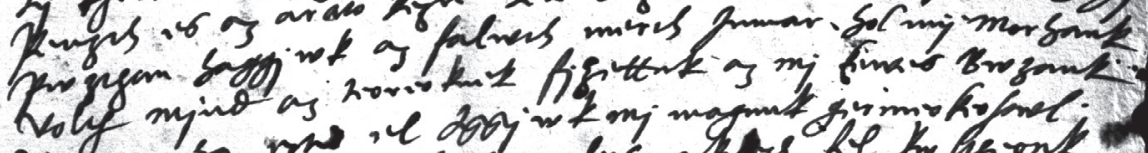

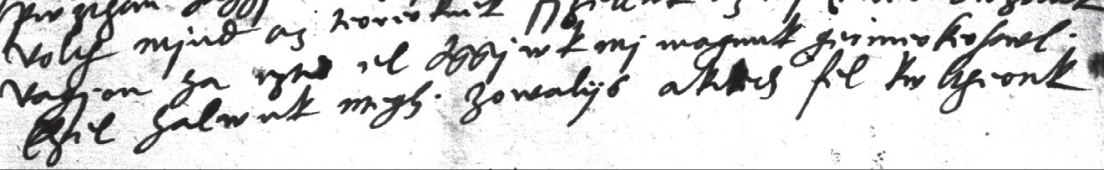

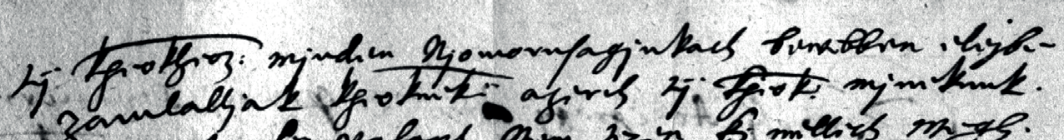

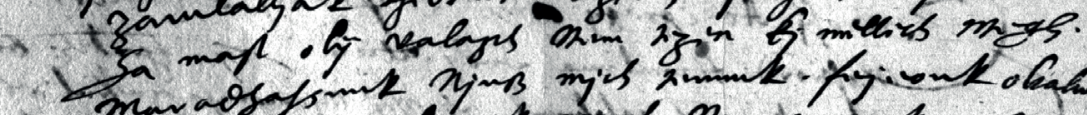

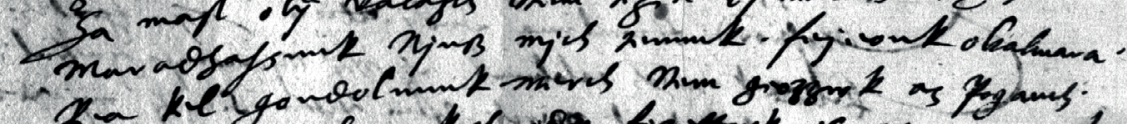

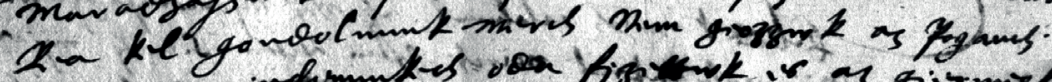

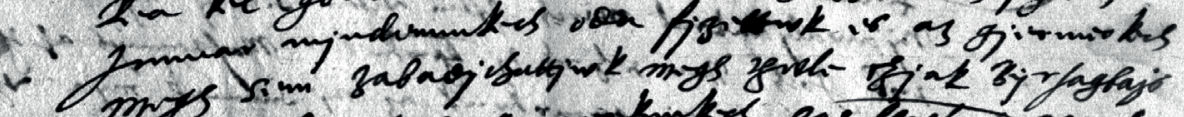

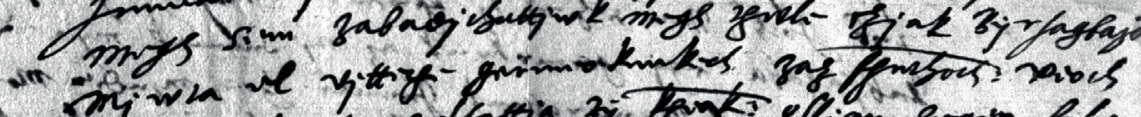

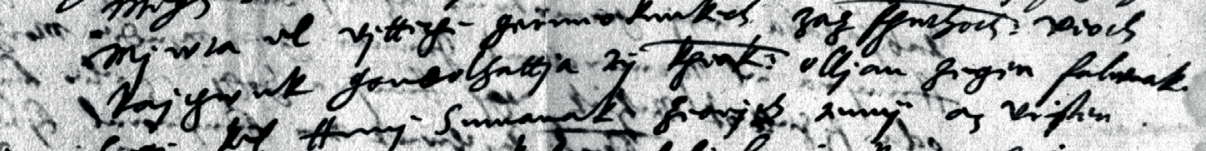

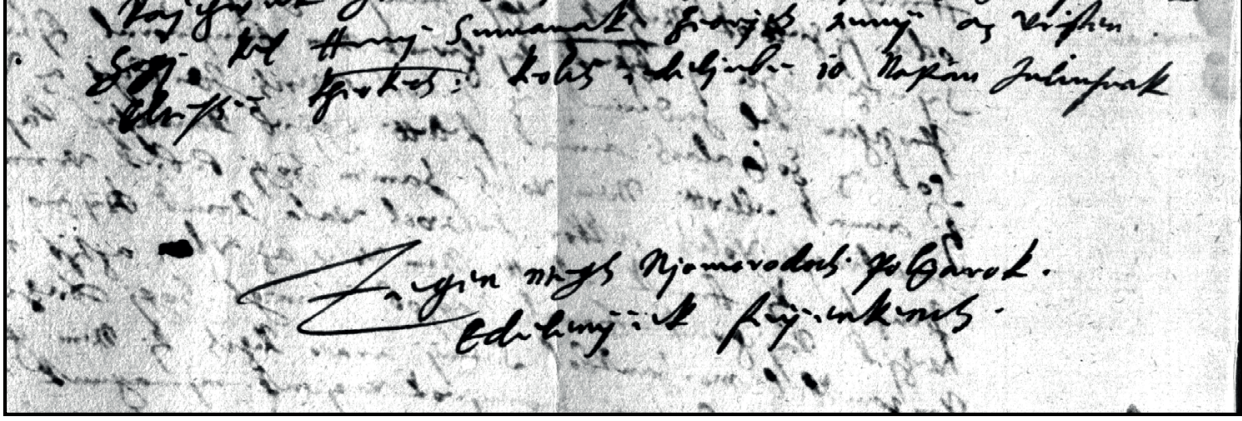


tÿ kgeoks Rajthunk Nem keonjeorul es · az Dÿzno tÿzed · penzth es az arato Rezre Rea dezmaltath atalanfogwa hogj pwzthan haggjwk az falwth merth Immar · hol mÿ morhank volth mjnd az teoreoknek fjzettuk az mj kewes Bwzank · vagjon ha eztis el Aggjwk mj magunk germeokeostwl · Ehel halwnk megh · zowalÿs akiketh ${ }^{6}$ fel kwltheonk

tÿ kgeokheoz mjnden Njomorusagjnkath bewebben elejbe zamlalljak kgeoknek azerth tÿ kgeok mjnekunk · ha mast olÿ valazth Nem tezen kj melleth megh . maradhassunk Njncz mjth tenunk · fejeonk oltalmara · Rea kel gondolnunk merth Nem geozzwk az poganth · Immar mjndenunketh oda fjzettwk es az gjermeoketh megh sem zabadjthattjwk megh thwle czjak Bÿrsagbajs mjwta el vjttethe germeokunketh zaz ffnthoth veoth Rajthwnk gondolhattja tÿ $\overline{\text { kgeok }}{ }^{7}$ olljan zegen falwnak · hogj kel Annj sumanak zeorÿth tennÿ az vristen Eltesse kgeoketh keolth edeljnbe 10 Napan Juliusnak

Zegen megh Njomorodoth · polgarok · Edelenÿek feÿenkenth ·

${ }^{6}$ A második $k$ tintafoltos.

${ }^{7}$ Az $o$ javított betü. 

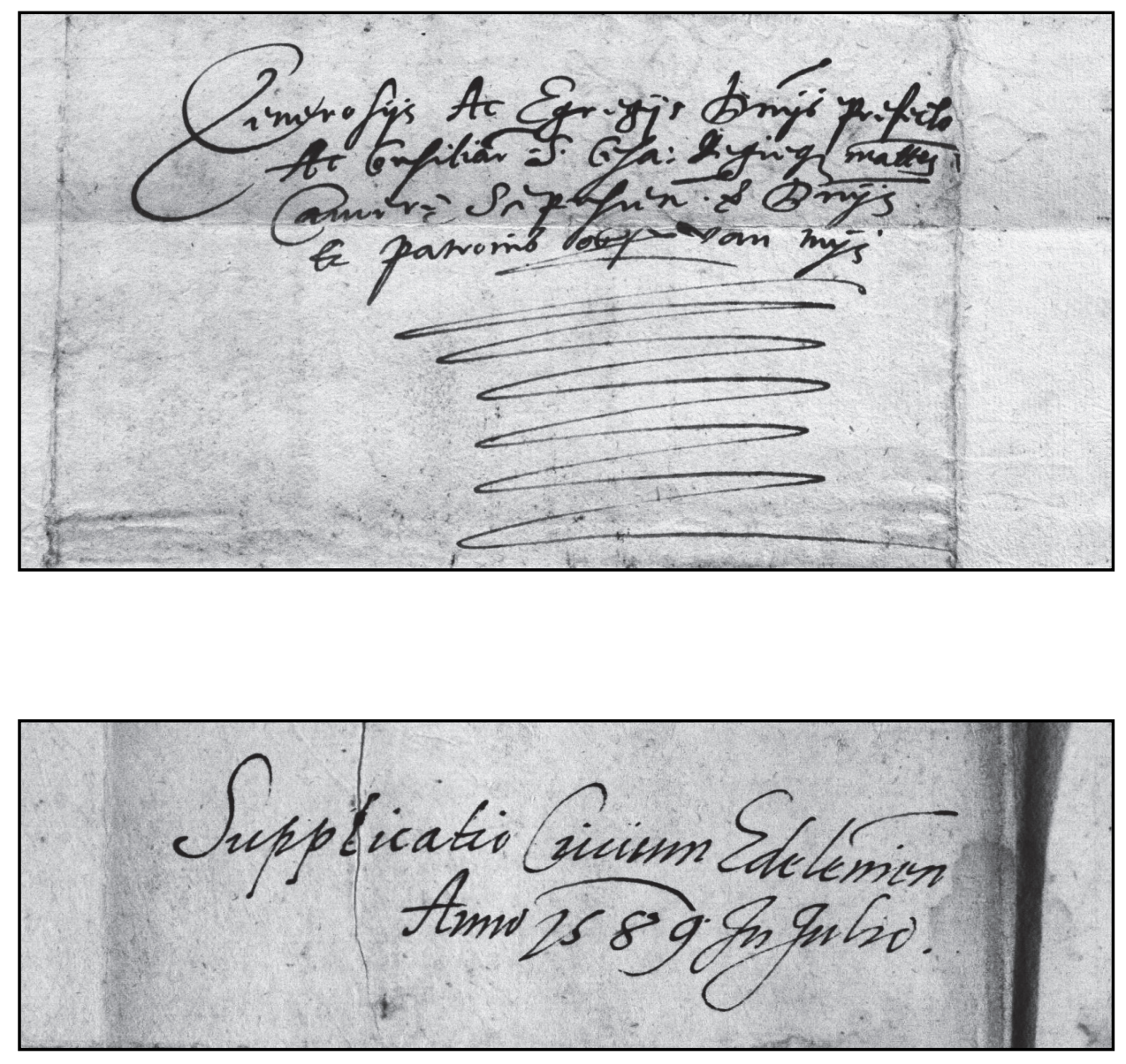
Kivvül:

Generosÿs Ac Egregÿs Dominÿs prefecto

Ac Consiliariis Sacre Cesaree Regieque maiestatis

Camerae Scepusiensis et Dominÿs

Et patronis observandis mÿs

Más kézzel írva:

Supplicatio Ciuium Edeleniensium

Anno 1589 In Julio. 
E 254 - 1590. okt. No. 28.

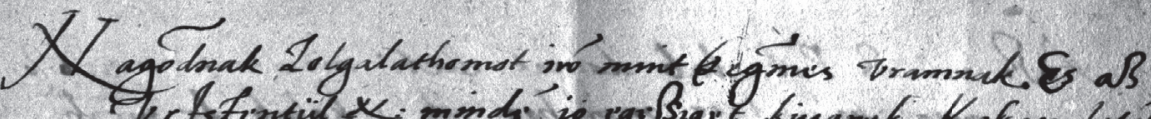

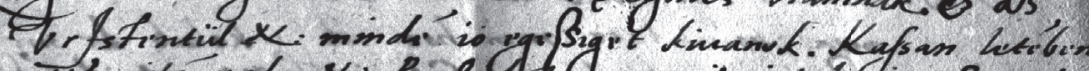

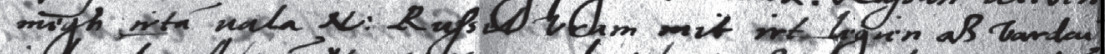

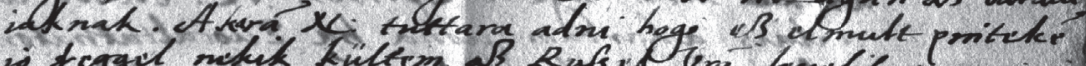

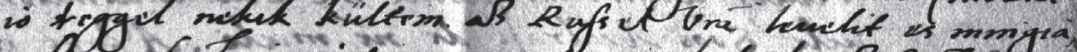

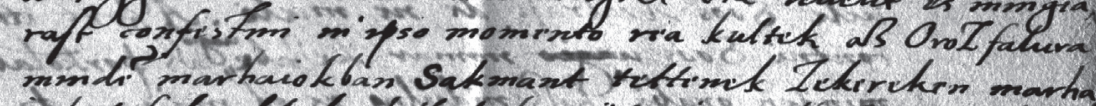

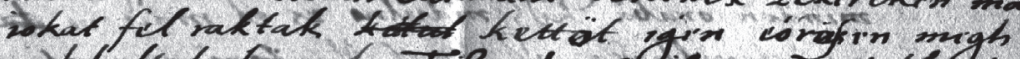

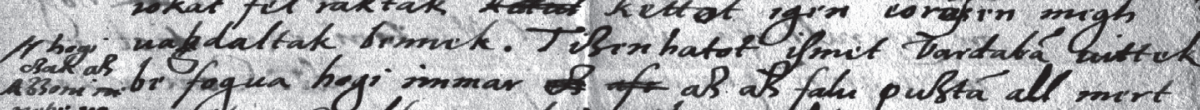
gif"

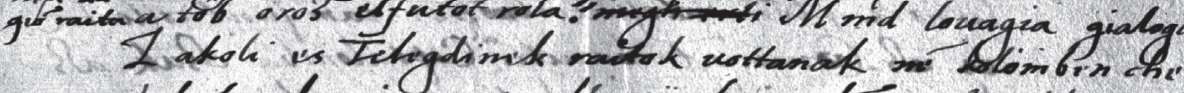

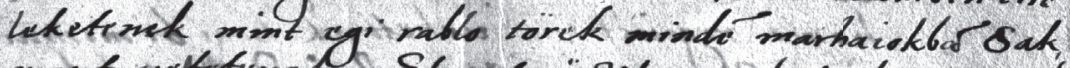
mant wettincke. Elyjt inkit magekat deigi $x$ :

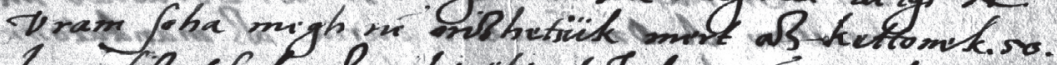

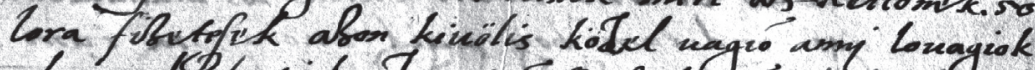

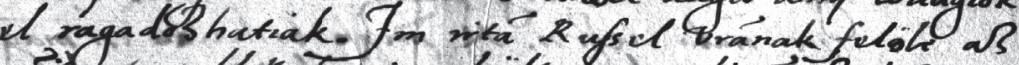

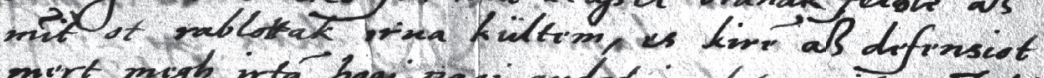

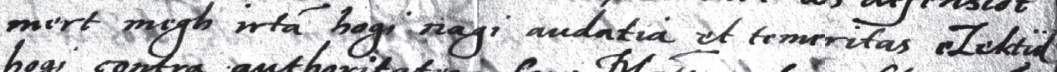

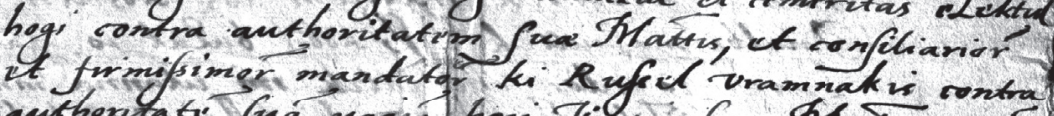

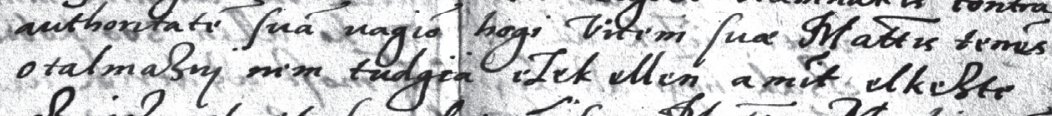

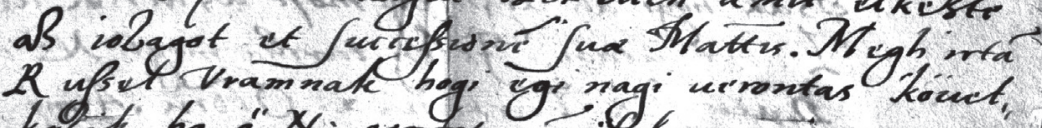

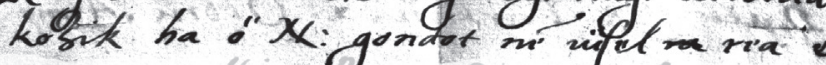




\section{I.31.}

Tárkány, 1590 X. 13. Debreközi János levele.

Naḡodnak zolgalathomot iro mint keḡmes ${ }^{1}$ vramnak. Es $^{2}$ az Vr Istentül N: mindē io egesseget kiuanok. Kassan leteben megh irta uala N: Russel vram mit irt legien az vardai iaknak. Akara N: tuttara adni hogi ez el mult pinteke io reggel ${ }^{3}$ nekik kültem az Russel vrā leuelit es mingiarast confestim in ipso momento rea kultek az Oroz falura minde marhaiokban Sakmant tettenek zekereken marhaiokat fel raktak $<$ k.t.t $>$ kettöt ${ }^{4}$ igen eörössen ${ }^{5}$ megh uakdaltak ${ }^{6}$ bennek. Tizenhatot ismet vardabā uittek be fogua hogi immar <ez as. $>$ az az falu puztā all mert a töb oroz elfutot rola. hogi czak az Azzoni ${ }^{7}<$ ne $>$ nepe uagiō raita $^{8}<$ megh erti $>$ Mind louagia gialogia

Zakoli es Telegdinek raitok uottanak nē kolömben che leketenek mint egi rablo törek minde marhaiokbā Sakmant uetetenek. Eleget örzik magokat de igi N:

vram soha megh nē orizhetiük mert az kettonek. 50. lora fizetesek azon kiuölis közel ${ }^{9}$ uagio annj louagiok el ragadozhatiak. Im irtā Russel vrānak felöle ${ }^{10} \mathrm{az}$ mit ot rablottak irua kültem, es kire az defensiot mert megh irtā hogi nagi audatia et temeritas ezektül hogi contra authoritatem Suae Maiestatis, et consiliariorum et firmissimorum mandatorum ki Russel vramnak is contra authoritate $m$ sua $m$ uagio hogi vitem suae Maiestatis tenens otalmaznj nem tudgia ezek ellen amit elkezte az iozagot et Successionem Suae Maiestatis. Megh irta Russel vramnak hogi egi nagi uerontas köuetkozik h ö N: gondot ne uisel <ra $>$ rea es manu

\footnotetext{
${ }^{1} \mathrm{~A} k$ javított betü.

${ }^{2}$ Az $E$ talán $e$-böl van javítva.

${ }^{3}$ A $r$ javított betü.

${ }^{4} \mathrm{Az} \ddot{o}$ e-ből van javítva.

${ }^{5}$ A második $\ddot{o}$ javított betủ talán $e$-ből, esetleg $u$-ból.

${ }^{6} \mathrm{~A} k g$-böl javított betü.

${ }^{7}$ Az $A$ a-ból van javítva.

${ }^{8}$ Hét szónyi betoldás a bal margóról, jelekkel a helyére utalva.

${ }^{9} \mathrm{~A} z$ javított betü.

${ }^{10}$ Az $\ddot{o} e$-ből javított betú.
} 


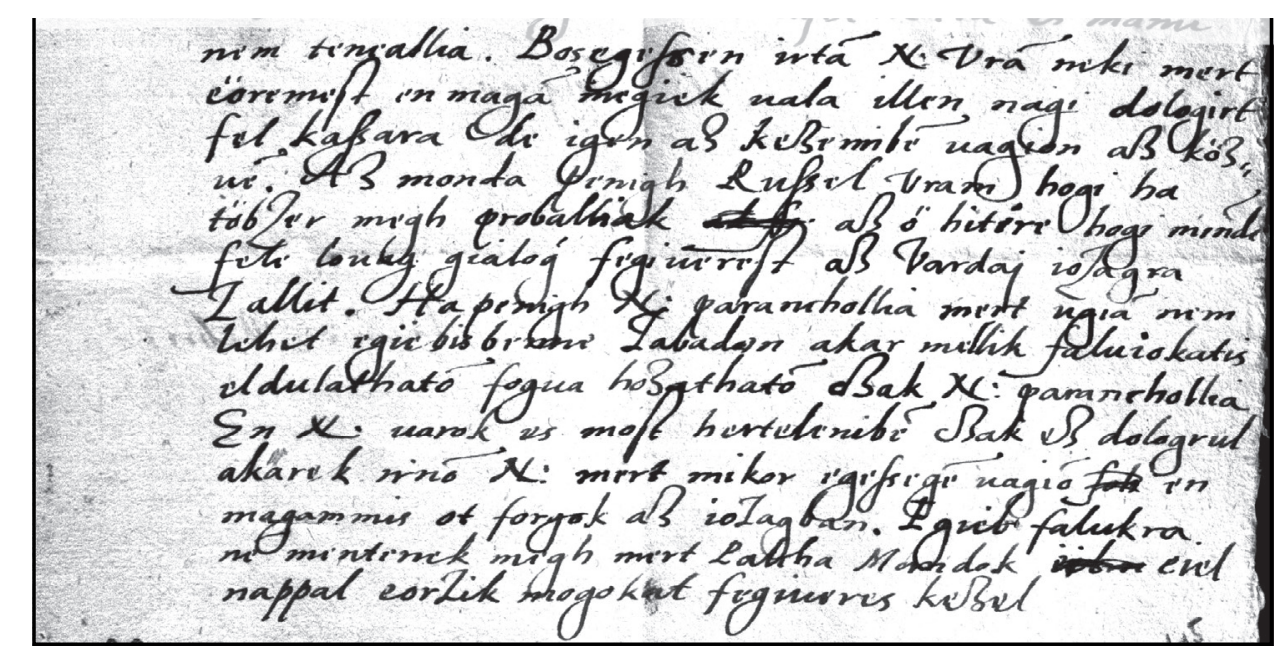

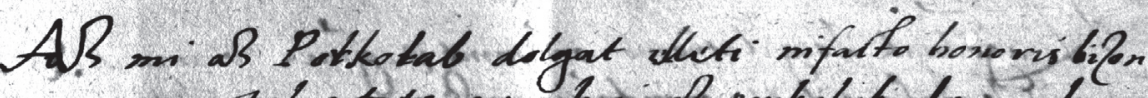

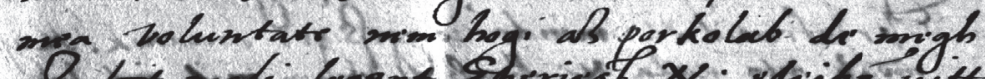

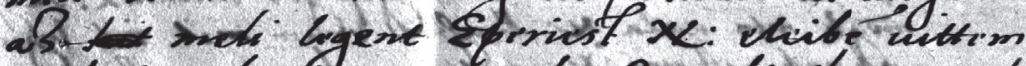

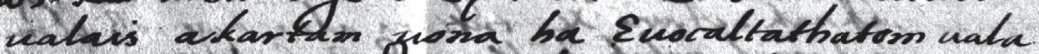

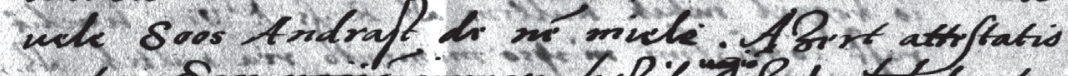

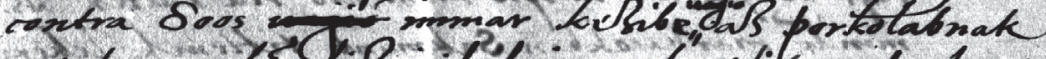

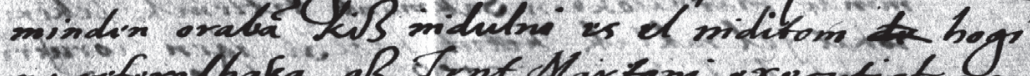

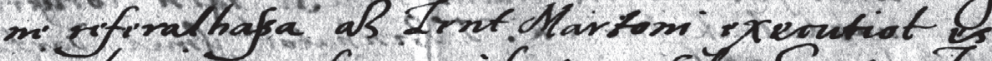

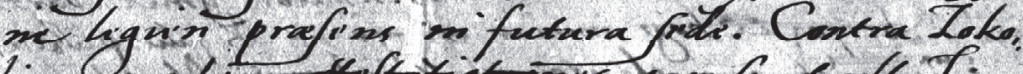

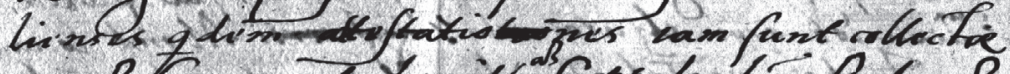

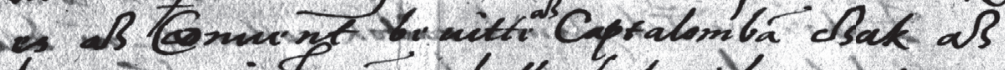

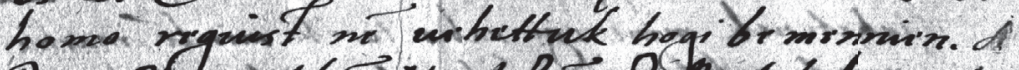

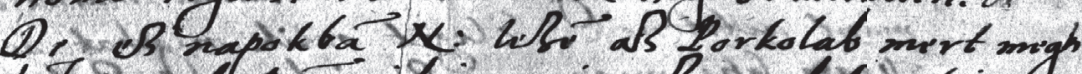

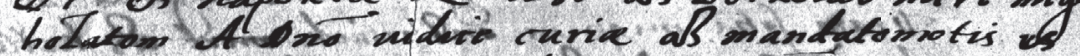

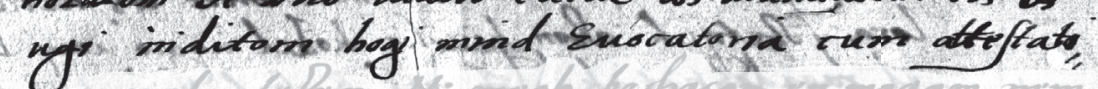


nem teneallia. Bosegessen ${ }^{11}$ irtā $\mathrm{N}$ : vrā neki mert eöremest en magā megiek uala illen nagi dologirt fel kassara de igen az kezeimbē uagion az közue . Az monda penigh Russel vram hogi ha töbzer megh proballiak <ad.s.. > az ö hitire ${ }^{12}$ hogi minde fele louag gialog ${ }^{13}$ fegiuerest az Vardaj iozagra zallit. Ha penigh N: paranchollia mert ugiā nem lehet egiebis benne zabadon akar mellik faluiokatis eldulathatō fogua hozathato czak N: paranchollia En N: uarok es most hertelenibe czak ez dologrul akarek irnō N: mert mikor egessege uagiō $<$ soh $>$ en magammis ot forgok az iozagban. Egieb falukra ne mentenek megh mert Palcha Mandok <e..b.. > eiel nappal eorzik mogokat fegiueres kezel

$\mathrm{Az}^{14} \mathrm{mi}$ az Porkolab ${ }^{15}$ dolgat elleti infacto honoris bizon mea voluntate nem hogi az porkolab de megh az $<$ kit $>$ meli legent Eperiest N: eleibe uittem ualais akartam uona ha Euocaltathatom uala uele Soos Andrast de ne miele. Azert attestatio contra Soos $<$ uagiō $>$ immar kezibe uagio ${ }^{16}$ az porkolabnak minden orabā kiz indulni es el inditom $<$ de $>$ hogi ne referalhassa az zent Martoni executiot es ne legien praesens in futura sede. Contra zokolienses quidem attestatio $<\ldots>$ nes iam sunt collectae ${ }^{17}$ es az Conuent ${ }^{18}$ be uitte az ${ }^{19}$ Captalombā czak az homo regiust ne uehettuk hogi be mennien. ${ }^{20}$ De ez napokbā N: lezē az Porkolab mert megh hozatom A Domino iudice curiae az mandatomotis es ugi inditom hogi mind Euocatoria cum attestati-

\footnotetext{
${ }^{11}$ A második $s$ talán javított betü.

${ }^{12}$ A második $i$ e-böl javított betü.

${ }^{13} \mathrm{~A}$ második $g$ fölötti vonás funkciója ismeretlen.

${ }^{14} \mathrm{Az}$ A a-ból javított betü.

${ }^{15} \mathrm{Az} r$ és az $l$ javított betűk (eredetileg a levélíró felcserélhette őket).

${ }^{16}$ A szó interlineáris betoldás, jellel a helyére utalva.

${ }^{17} \mathrm{Az} a$ más betünek indult.

${ }^{18}$ Az o javított betü.

${ }^{19}$ Az szó interlienáris betoldás.

${ }^{20}$ A szó után törölt $d$ nyoma látszik.
} 

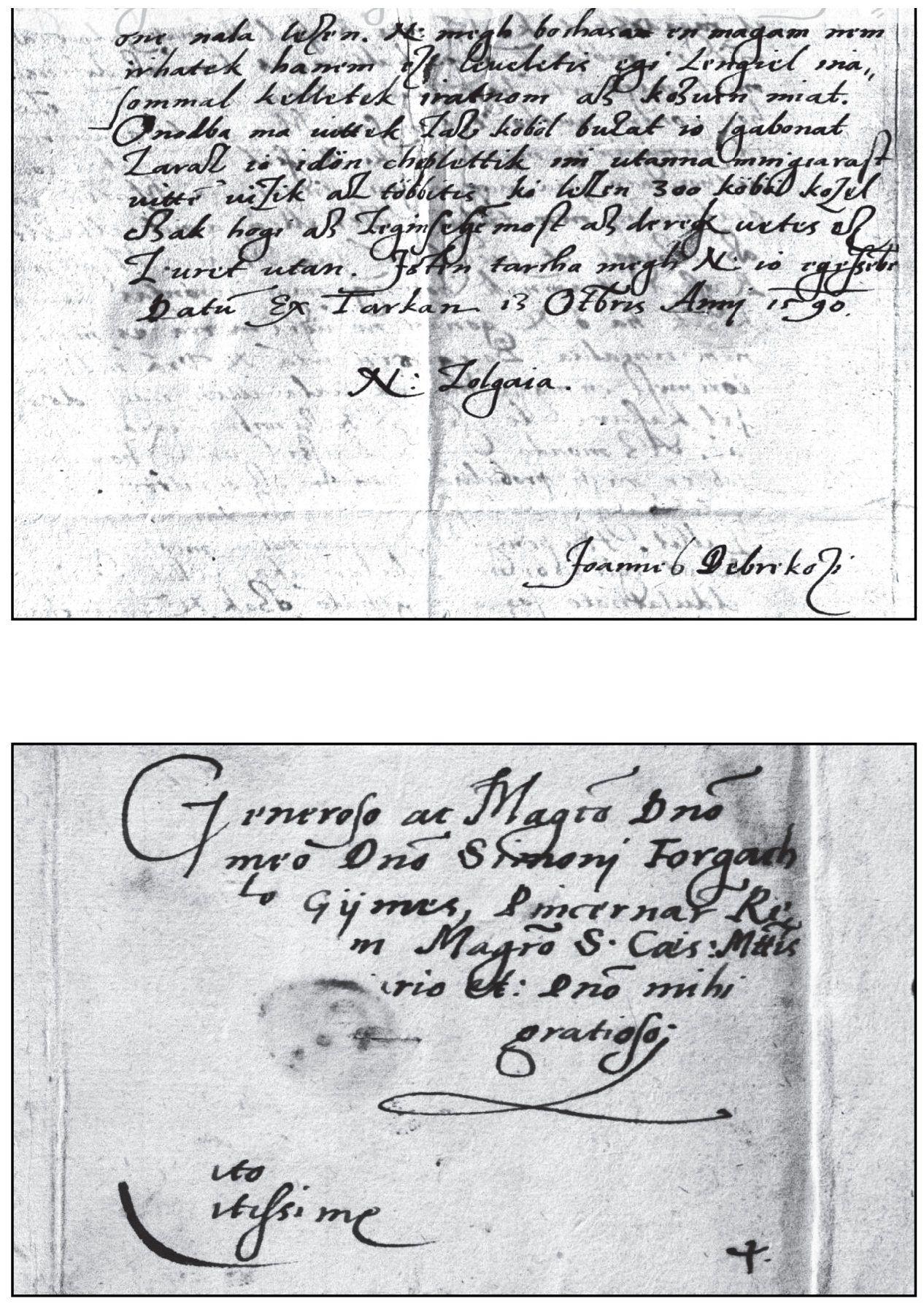
one $^{21}$ nala lezen. $\mathrm{N}$ : megh bochasa $<\mathrm{n}>$ en magam nem irhatek hanem ez $<\mathrm{t}>$ leueletis egi Lengiel inasommal kelletek iratnom az kozuen miat.

Onodba ma uittek zaz köböl buzat io $<.>^{22}$ gabonat zaraz io idön cheplettik im utanna mingiarast uitte uizik az többitis ki lezen 300 köböl kozel czak hogi az zeginsege ${ }^{23}$ most az derek ${ }^{24}$ uetes ez zuret utan. Isten tarcha megh $\mathrm{N}$ : io egessebe Datum Ex Tarkan. 13 Octobris Anni 1590.

$\mathrm{N}$ : zolgaia.

\section{Joannes Debrekozi}

Kìül:

Generoso ac Magistro ${ }^{25}$ Domino

meo Domino Simoni Forgach

Gÿmes, ${ }^{26}$ Pincernarum Regaliu

m Magistro Sacrae Caesareae Maiestatis

consiliario et: Domino mihi

gratioso. etc

cito $^{27}$

citissime

\footnotetext{
${ }^{21}$ A szóban több javítás is látszik: a második $t$ javított betü, az $i$ pedig $o$-ból van javítva.

${ }^{22}$ A szó elött feltehetőleg törölt betű nyoma látszik.

${ }^{23} \mathrm{~A} g$ javított betü.

${ }^{24} \mathrm{~A} k g$-böl javított betü.

${ }^{25}$ Az olvasat a rövidítés jellege miatt bizonytalan.

${ }^{26}$ A köztes sorban Lo betükapcsolat látszik.

${ }^{27}$ A cito és a citissime c-je közös; jobbra egy magában álló jelzés látható.
} 


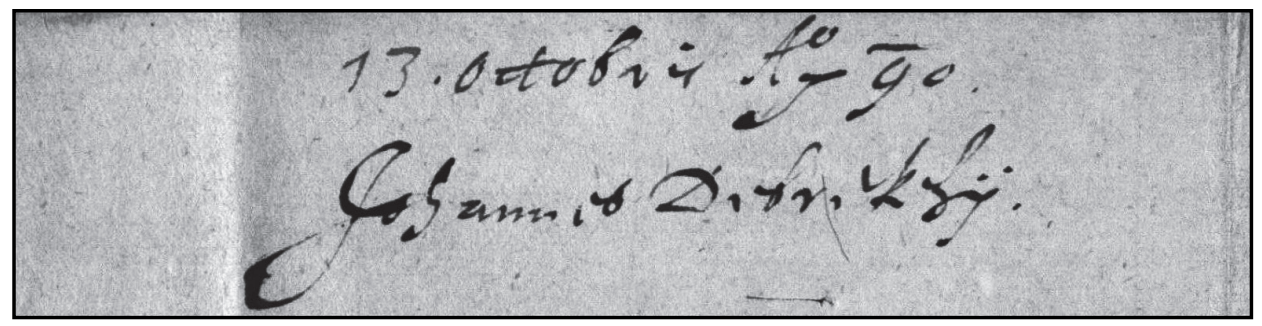


Más kézzel irva:

13 Octobris. Anno 590

Johannis Debrekezÿ. 
Az I.1-31. levél leváltári jelzete

\begin{tabular}{|c|c|c|}
\hline A LEVÉL SZÁMA & A LEVÉL DÁTUMA & LEVÉLTÁRI JELZET \\
\hline I.1. & 1547. VIII. 6, Jászó & E $41-1547$ No. 19. \\
\hline I.2. & 1549. IV. 17. Jászó & E $41-1549$ No. 42. \\
\hline I.3. & 1549. VI. 23. Kapornak & E $41-1549$ No. 63. \\
\hline I.4. & 1549. VII. 2. Kapornak & E $41-1549$ No. 68. \\
\hline I.5. & 1562 előtt. Ete & $\begin{array}{l}\text { E } 200-22 \text {. tétel Horváth de } \\
\text { Sziget -9. d. } 50 \text {. fol }\end{array}$ \\
\hline I.6. & 1564. VIII. 13. Letenye & E $41-1564$ No. 91. \\
\hline I.7. & 1573. XI. 13. Nagyölved & E $41-1573$ No. 38. \\
\hline I.8. & 1575. I. 12. Csetnek & E $254-1575$. jan. No. 9. \\
\hline I.9. & 1575. II. 6. Pelsőc & E 254 - 1575. febr. No. 16. \\
\hline I.10. & 1575. X. 16. Dorog & E 254 - 1575. okt. No. 23. \\
\hline I.11. & 1578. VI. Görömböly & E $154-1578$. jún. No. 60. \\
\hline I.12. & 1579. VII. 17. Etyek & E 254 - 1579. júl. No. 22. \\
\hline I.13. & 1580. IX. 1. Károly & E 254 - 1580. szept. No. 1. \\
\hline I.14. & 1580. XI. 13. Károly & E $254-1580$. nov. No. 2. \\
\hline I.15. & 1581. I. 22. Mocsonok & E $41-1581$ No. 17. \\
\hline I.16. & 1581. X. 23. Inota & R 307 - Inota (6. d.) \\
\hline I.17. & 1582. VI. Sajógömör & E 254 - 1582. jún. No. 27. \\
\hline I.18. & 1582. VI. Kassa & E 254 - 1582. jún. No. 26. \\
\hline I.19. & 1582. XII. 8. Nagybánya & E 254 - 1582. dec. No. 2. \\
\hline I.20. & 1584. Varjas & E $254-1582$. No. 28. \\
\hline I.21. & 1585. I. 16. Liszka & E $254-1585$. jan. No. 2. \\
\hline I. 22. & $\begin{array}{l}\text { 1585. VI. } 5 \text { előtt. } \\
\text { Krasznahorka }\end{array}$ & E 254 - 1585. jún. No. 28. \\
\hline I.23. & 1585. VI. 15. Püspöki & E $41-1585$ No. 14. \\
\hline I.24. & 1586. II. 3. Vágszerdahely & E $41-1586$ No. 6. \\
\hline I.25. & 1586. VI. 14. Licse & E 254 - 1586. jún. No. 23. \\
\hline I.26. & 1587. III. 7. Tokaj & E 254 - 1587. márc. No. 33. \\
\hline I.27. & 1587. VII. 13 elött. Tarcal & E 254 - 1587. júl. No. 51. \\
\hline I.28. & 1588. VIII. 4. Szádvár & E 254 - 1588. aug. No. 9. \\
\hline I.29. & 1588. XI. 4. Maros & E $41-1588$ No. 51. \\
\hline I.30. & 1589. VII. 10. Edelény & E 254 - 1589. júl. No. 45. \\
\hline I.31. & 1590 X. 13. Tárkány & E 254 - 1590. okt. No. 28. \\
\hline
\end{tabular}


A levéltári törzsszámok feloldása:

E 41

Magyar Nemzeti Levéltár Országos Levéltára - Magyar kincstári levéltárak - Magyar Kamarai Levéltár - Magyar Kamara regisztratúrája - Litterae ad cameram exaratae

E 254

Magyar Nemzeti Levéltár Országos Levéltára - Magyar kincstári levéltárak Szepesi kamarai levéltár - Szepesi Kamara (kassai adminisztráció) regisztratúrája Repraesentationes, informationes et instantiae

E 200

Magyar Nemzeti Levéltár Országos Levéltára - Magyar kincstári levéltárak Magyar Kamara archivuma - Acta diversarum familiarum

R 307

Magyar Nemzeti Levéltár Országos Levéltára - 1526 utáni gyüjtemény - Vegyes, tárgyi alapon létrehozott gyüjtemények - Községi iratok 



\section{II. \\ Levelek utánközlésként}

Közreadta: Eckhardt Sándor 


\section{Megjegyzés}

A lentebb következő levelek és levélrészletek - eredeti kéziratok hiányában, a Bevezetőben is leírtaknak megfelelően - az első közlés szövegét tartalmazzák. Ezek tehát egy az egyben megegyeznek a Magyar Nyelv adott számaiban megjelent szövegekkel. (A megjelenési helyek felsorolását 1. lentebb.) A minimális - és hibalehetőség nélküli - egységesítés érdekében pusztán annyit tettünk, hogy az $\int$ és $\beta$ betủiket kicseréltük $s$-ekre, illetve $s z$-ekre. A közlő azon jegyzeteit, amelyek az írásképpel kapcsolatosak, természetesen hiánytalanul megtartottuk. 
19 levél a korábbi átirat szerint 


\section{II.1.}

\section{Nagyszölö, 1574. III. 8. Nagyszölöi jobbágyok levele.}

Eorekke walo zolgalatunkat aÿanlÿok the Nagtōknak. Mynth kegmes Wrwnknak. Thowaba the nagtonak ezt ackarank thwtara adnonk. hogÿ Balassÿ Janos mÿat es az eo zolgaÿ mÿat mÿnemeo nagÿ Insigben es Nÿomorussagban wagÿonk az el mwlt szöretkorth. Eomaga tompa ferench wram. Tÿztartonk ott wolt keköben. Amÿkor rä köldette uala Balassÿ Janos zolgaÿt. Es el witette tolonk erövel. az Boor dezmat. kÿerth hyzök. hogÿ megÿs talaltta ez ideÿgh . the nagtokat ferench Wrã̃. Mostan esmegh az Bwza Dezmath . megh kerÿ raÿtonk. hogy megh wÿgok nekÿ. Wywarbol esmegh Tÿztartonk. Tompa ferench Wram. megh kerÿ raÿtonk. az kÿnek adot wolt. azzegenÿ megh holt. Ersek wrwnk. Azert az ket koszben. nem. thudunk howa lennÿ. merth Wdwar bÿroÿs ÿrton ÿr reank. hogy meghneaggÿok kekoben. Merth keppen [!] megh wezÿ raÿtonk. The Nagtoknak. konÿergonk. az hatalmas Istenÿrth. hogÿ aggÿon modot benne, mÿth kellessonk mÿwelnonk. merth nem. tudhonk howa lennÿ. az sok Insigh mÿath. oda kekobenÿs szÿnten wgÿan szolgaltattnak bennonket. Mÿnth ha oda walo Jobagÿok wolnank. Maga regenten soha. massowa nem. zolgaltonk hanem. az ersek kezehez. The nagtok. az hatalmas Istenÿrth legyen oltalmonk es gondui ̃̂elonk mÿnd ezekbol. Merth nem [!] kiketellen pwstan kel hadnonk. az zegenÿ falut. merth nÿluan wagÿon nagnal. hogÿ szÿnten az thoreknek torkaban wagÿonk. De megÿ az sem chelekessik welonk olÿ ektelenol. mÿnth az Balassÿ Janos zolgaÿ. Wgÿan el ostoth bennonket zolgaÿnak mÿnth Jobbagỳi. wgÿ zolgaltattnak welonk. az mÿnth ackarÿak. Mÿ melletonk. az eo Jobagÿat megh kimÿlli Azerth the nagtok. wagÿ wÿwarbol szakasson el bennonket, wagÿ hogÿ kekoben ne zolgaltassanak welonk. merth pustañ marad az zegenÿ falu. Most chak hogÿ. megh nem ackartok. Elozer ÿelentenonk the nagtōnak. hogÿ wiselje gondunkat. Towaba az buza Dezmath megh kerik raÿtonk. hogÿ kekoben wigÿok. Wÿwarban tÿztartonkÿs kerÿ tolonk, azerth the Nagtok, wagÿ azt rendelÿe. hogÿ Balassÿ Janossnak aggÿok megh. Wagÿ hogÿ <hogÿ> tÿztartonknak. merth az ket rezre nem geöszok meg adnÿ

Towaba megh nem Eligesznek. mÿnd ezekkelÿs. hanem̃ az Balassj Janos haÿdwÿth reank bochattÿak. Es wgÿ wÿtettnek. Nÿakon keöttwe bennonket. Annak felette, amÿt kaphattnak hazwnk taÿan. mÿndent el wÿsznek. Jllÿen nagy Jnsigben wagÿonk. Towaba Wÿwarban esmegh eröltettnek hogÿ palanknak walo faath hoszonk. az ket köszben nem thudonk howa lennÿ. Merth kekobol nÿnch Nÿugodalmonk.

Az mÿnt . az Warmegÿe rendelte woltÿs. hogÿ mÿt zolgalỷonk oda kekoben azt regen megh zolgaltok. Maga mÿ azt sem thwgÿok. rendelteÿ wagÿ nem chak hogÿ tollek hallotok. Azth rendelte wolt. hogÿ ha keszeltettnek velonk tahat egy embernek egy napra. tÿz penzt aggÿanak. Es ha egÿ zeker zenat fel wÿzonk. az Warban. attolÿs tÿz penzt aggÿanak. Ez ideigh soha semÿt nem attanak. hanem. 
mÿnth. thulaÿdon. Jobagÿwal. megÿ Jncab. wgÿ zolgaltattnak bennonket. Azert nagtok. az Istenÿrth. oltalmazon megh bennonket. Mÿnd ezektol. merth nem [!] kikittelen elkel wesznonk. es pwstwlnonk. Ez sok nÿomorwssagban.

Towaba nagtoknak. azonÿs konÿergonk. mÿnth kegmes Wrunknak. hogÿ Balassÿ Janossnak. wagÿon. egy faluÿa. Bussanak hÿak. kÿ Dÿwinhez tartoszo. az mÿ falunknak zomzedsagaban wagÿon. Regÿ ween emberek wannak kösztonk. kÿk soha nem emlÿtik, hogÿ kölemb hatarok leth wolna. az ket falunak. hanem mÿnd egÿ wolt. Az baromillö folden wgÿan eggÿoth eörzettek. ha egÿ bokorban ÿart Eggÿkönknek barma. Az massik falunak. megÿ az maas Bokorban ÿarth. soha egÿ sem bantotta egÿ maas barmath. Most Immar megh fogÿak barmonkat. es penzen aggÿak kÿ. kÿ soha nem wolt köszetönk. sem senkÿ nem emlÿttÿ köszetonk. Azerth könÿergonk. the nagtoknak. abbolÿs. hogÿ <nagtok> the Nagtok oltalmazzon megh abbolÿs bennonket. parancholna megh. Balassÿ Janossnak. hogÿ ne bolgattnanak bennonket. Merth soha nem wolt az köszetonk. ezideigh. The Nagtoktol. mÿnth keḡ̄es Wrwnktol. Jo walazt waronk.

Az Egez. falu Nagÿ Zeoleÿek. Eo felsige Zegenÿ megh nÿomorodot. Mostan [!] Jobbagÿ.

Humillima supplicatio totius villae. Nagÿ Zeoleö In Comitatu Neugradiensi. Zegenÿ megh nÿomorodot Nagÿ Zeoleÿek keonÿergise.

8. Martÿ. Anno. 74. Contra Dom. Jo. Balassa. 


\section{II.2.}

\section{Sajókeresztúr 1577. Sajókeresztúri jobbágyok levele.}

Mi Saio kerezturj Birak es polgarok, kiczentwl fogŭa nagik, Eórőkke valo szolgalathonkat aianlÿuk vrasagtoknak mint tiztelendeo vitezleo vronknak.

Thouaba, akarok vrasagtoknak ielentenj az mi falŭnknak nagÿ nÿomorusag es ketelenseg ala vetteteth allapattÿat, az termezet zerent raÿtonk kegyetlenkedeo pogansag miatth. melÿ nagÿ nÿomorusaginknak okaiban eleo zamlaluan vrasagtoknak, legyen iteleo bar vrasagtokis benne ha nem nagÿ ketelenseggel nÿomorgattatŭnk. Ezek, tudnj illik, Mikoron mi elŏzŏr az pogan kenseritesebŏl az mi vekonÿ erŏnk zerent meg saczoltonk uala Hazon aganak, somankat vegeztŭk vala el 335. forintban es ket zaz Icze mezben

Annak utanna mikor Dedest meg veuek az Halmaÿnal vala taborok, az mi kiczen falunkat meg zamlalŭan hazan kent, kwldeŏk az Birotth oda hozaia, az biro el vegezte vele, es nagÿ eskŏuesre azt monta hogÿ ha meg enÿ wolna kereztur az mint zamon $<$ be $\mathrm{v}>$ meg vittek nekieis soha teŏbet nem vezen $\overline{4}$. zaz forintnal, czak hogy arrul elegitswk meg, Annak is latŭan hogÿ egyeb nem lehet benne engedenk. Mostan imár anÿera fel verte somankat es olÿ igen meg nÿomoritotta az zegenÿ falut, hogÿ czak az derek somais hat zaz forint, es az ket zaz icze mezet is mostan verte fel .3. zaz iczere. Annakfelette, kit annak elŏtte nem keuant, czak az Zw Basanak ŭŏtth rajtonk .20., forintotth. koczÿ penzt is mostan vŏtth raÿtonk $\overline{18}$ forintotth. Harom vago tehenert ki an̄akelŏtte kettŏ uala 15. <eotth $>$ forintott uŏtth. Im mostan is uŏttŏnk ket louat $\overline{32}$ forinton, Egÿ koczit $\overline{8}$. forinton, az loŭaknak penig vrak loŭahoz, illendeo fekeket es hamokat $<$ aze> keuant kit zerzettŏnk .j. mas fel forinton. Harom koczinkat tŏbig tartotta otben Pesten $\overline{.4}$. holnapnal, kikŭel annak elŏtte nem bantott, azoknakis teobet fizettŏnk $\overline{50}$ forintnal. Mind ezekkel czak mostan (az elŏtt nem ŭolt) akar meg nÿomoritanj. Vrasagtok iol tw̌ggia ennekfelette melÿ nagÿ zolgalattal vagionk az nemeteknek is oda be Zenderŏben, melÿ ket fel kŏzŏtt ualo nagÿ insegben, czak az Isten eǒ felsege latty்a melÿ igen el farattonk es minden eletŏnkben el fogiatkoztonk: Annak okaert az Hatalmas Istenert esedezŏnk es kŏnÿŏrgonk Vrasagtoknak mind feien kent, hogj midd ezeket az sok nÿomorusagokat meg tekintŭen, az mj esedezesŏnket halgassa meg vrasagtok es meg zanŭan vrasagtok az zegenÿ falŭnak nÿomorusagat, Irion vrasagtok az zegen Jŭhokon kegietlenkedo̊ farkasnak az Hazon aganak hogj legien engedelmesb hozank, mert ha ezen meg kemenÿtet ziŭel leend hozank, kik im'ar telÿesseggel el sajtolottonk bizonÿ noha nagj karonkal es sok ideig nagÿ faradtsaggal ipitett, eǒrŏksegeczkenk nelkwl kel lennŏnk, de mi keppen az keg'etlen forgo szel mia az por el ozlatik, semmÿ keppen mies meg nem maradhatonk az mi eöröksegŏnkben hanem el kel budosnonk, ennek raÿtonk ualo nagÿ kegÿetlensege miat. Mind az altal minekŏnk zegenÿ allapatŭ embereknek vrasagtokban nagÿ remensegŏnk vagion. 
Annak felette Vrasagtokat keriwk azon hogÿ minekŏnk kik, netalan sok bezeduel valo ${ }^{1}$ könÿŏrgesŏnkel, meg is bantottuk vrasagtokat meg boczasson Vras:

Touba ez felŏl meg mondoth Zwksegónk kenzerit minket, hogÿ emlekeztessuk vrasagtokat rea az borok arrara.

Annakokaert keŏnyŏrgŏnk Vrasagtoknak, hogÿ meg tekintuén allapatŭnkat es zwksegŏnket, vrasagtok az el foglalt boroknak az arrat tŭdni illik mind az eztendeit es az taualit 28. bor arrat ielencze meg Vrasagtok kitwl kel varnonk, mert az Boldisar deakkal semmi iot nem erŏnk, hanem Vrasagtoknak ${ }^{2}$ kŏnÿŏrgŏnk, Vrasagtok minket karban ne haggion, mert olÿ zegenyek vadnak kŏztok az kiket el foglaltak kinek czak egÿ ŭolt kinek ketto aztis el vŏttek, es nem tud miŭel fizetnÿ az teŏroknek.

Jo valazt varonk vrasagtoktŭl:

Alazatos Supplicatioia az zegenÿ nÿomoru allapatŭ falunak Saio kereztŭrnak.

${ }^{1}$ Javítva ebből: bezedwnkel.

${ }^{2}$ Javítva: urasagtokat. 


\section{II.3.}

Gergelyi, 1577. XII. Gergelyi jobbágyok levele.

Eoreoke walo Alazatos zolgalathwnkatth Irÿwkg Kegÿeteknekg myntth Bÿzodalmas oltalmazo patronwssÿnknakg. Istenteöl kegyeteknekg kewanonkg Mÿnd lelkÿ es testÿ Jokatt, hozzw Eletett es Jo zerenchet.

Keonÿeorgesseonkg Vrassagtoknak es Tÿ kegetek sokg wolna, de most sokwal kegeteket nem vntatthattÿwkg, Amÿtt Isten Bwneonkg zerÿntt reank boczatott az zertelen walo halaltt, az Varhoz farattssagos sok zolgalatotth, es az pogannak zwntelen walo fÿzetesth, aztth megÿs mÿnd ell zenwedhettnw"kg, Jollehet Amenÿ sok Jambor Embernek keozwleonkg ell holtanak aztt hertelenssegwel kegeteknek megh nem twggywk jelentenÿ, de amÿ nekeonk Igen neheznek tecczÿk kÿtt semÿ keppen ell nem zenwedheteonkg, feokeppen keonyeorgesseonk ez kegÿeteknek, hogÿ mÿnket az zepsÿ fegÿweressek eÿel nappal sacczoltattnakg, zabott, zenatth es mynden elest kernek raÿthonk, Amÿ falwnkat mÿntt Egÿ Eeoreokeos Jobbagÿott attak az fegyweresseknek, kÿ soha theorwenÿeonk nem woltt, Amÿtt kwlegeteonkÿs (!) semmÿtt nekeonk erte nem fÿzettnekg, es mÿkor hertelen zerÿtt nem tehettÿwkg ektelen keppen nÿomorgattnak benneonket Nemellÿet keozeoleonk megh keoteoznekg, lanczra teznekg, mÿnd ezzel sem elegednek, seott megh valttsagon fÿzetessertt bochattnak ell, megh chak az az Vassarra sem mereonk teoleok mennÿ maga az pogannakÿs eleg fÿzetessbe es Insegbe wagÿonk, az Varhozÿs sok zolgalattal, az deogh halalÿs raÿthwnk, es az falwnak maÿd harmad reze keozeoleonkg ell holt, kÿ mÿa wgÿan el kezteonk fogÿattkoznÿ.

Annakokaertth, kegyeteknek mÿntt patronwssÿnknak keonÿeorgeonk, hogÿ tÿ kegÿetek legÿen mellettwnk, es tawoztassa az fele ok nelkwl walo dolgotth hogÿ mÿs az eo felsege Jozagaba az kegyetek zarnya alat maradhassonk megh, mertt altalan fogwa ell kel az falwrol menneonk es Idegen Varatt kel fogadnonk. Isten tharcha megh kegÿēteket hozzw Ideÿglen Jo egessegbe.

Chazar eo felsegenek zegÿn nÿomorodoth Jobbagÿ

Gergeÿekh

Suplicatio Colonorum Sacrae Caesareae Regiaeque Maiestatis Gergelÿensium humilima.

$2 X^{\text {bris }}$ 


\section{II.4.}

Tiszaeszlár, 1577. Tiszaeszlári jobbágyok levele.

Az Vur Istentől minden iot keuanunk Vrasagtoknak Ezen kőniőrg·w̋nk Az Vur Istenertis hogj neh hadgion Vrasagtok meg niomorodnünk my Ibranj Ferencz vram keze alat laktunk Ezlaron Az Töröknek zertelen nagj Fe[..]e fizetesw"nk uagion mostis hat szaz forintot ker raytunk, egj kochi louat, Egj üeg poztot, hat tehenet My faluyul be giwwlenk latuan ezt hogj nem lehetwwnk elegek az fizetesre Vgj uegezők hogj ha minden marhankat ell kőttiwwkis pw̋zta kezuelis ky kell belöle mennw"wn, Mert immar Az poganj meg Izente hogj felesegestől gyermekestől Rabba ${ }^{1}$ tezen bennw"nket, Job nekwwnk Az kereztien feyedelemnek byrodalmaban mennw"wnk es oth le telepednw"wnk hogj nem mint őrök rabba essw"nk, Ez felelemben Annyera uagionk penig hogj egj Eyel sem merw"wk falunkban halnj hanem atal Jőw̋unk Az tizan es ugj otalmazzuk magunkat. E zilaj Capitanj Vramnak meg mondok hogj my az poganj birodalmaban megh nem maradhatunk. Eztis meg Jelentők hogj Nekw"nk Örőksegw̋nk vagion Az tharczali fődőn melj őrőkseget az tőrők Adaia (!) fizeteseben fell akarnak tudnj Capitanj Vram igj biztata hogj ha ell jőhetnenk ő kezben Nem ad hogj az poganj rabsagaban Essw̋nk Ell Jőuenk Tharczalra az bironak be Attuk magunkat ő fölsegenek iobbagjsagara, Azonkőzben vduar biro vram Ibranj Ferencz Vramual Jöuenek Tharczalra Ez Debrej Martont Vduarbiro Vram kezeben Ada Ibranj Ferencznek Az Tharczali biro penig kerj uala VduarbiroVramat hogj neh Adna kezben, Monda Vduarbiro nem merem Mert Az kamora paranchiollỳa Ismet monda az biro töruenjnekw" ne ad kezben mig az kamoras Vrakat erik nam ő Vrasagokis ugj irta az leuelben hogj ha bizonios oka ninchen kezbem (!) Adassanak hat meg iria ked oda fell Azert Neh adgia ked kezben addig mind az atall vgian ell uiue Ibranj Ferencz. Kőniörgw̋nk Vrasagtoknak Neh adgion kezben Vrasagtok mint az Poganj kezben essw"nk, mert Ibranj Ferencz vram minket meg nem oltalmazhat Mert ő magais masut lakik Helmeczen. Ha penig kilömben nem Akaria Ibrany Ferencz engedgien töruent Vrasagtok benne, mert my Chiazar ő fősege Jobagjsaga alol haza nem Akarunk mennj, mert ez Debrej Marton Annak Elötteis mind Attiaual Egietemben Chiazar Jobagia uot, Az törők fogsagabol zabadult uotis ky. Az Vur Isten Algia es tharchia megh Vrasagtokat.

Supplicatio humilima Ad Generosas ac Eegregias Dominationes Vestras nec non Patronos.

${ }^{1}$ Javítva ebből: meabba, az $R$ csak az $m$ betüt takarja. 


\section{II.5.}

Tardoskedd, 1580. X. 18. Tardoskeddi jobbágyok levele.

O̊rókke ualo alazatos szolgalatunkat aÿalÿuk ${ }^{1}$ mÿnt Nagsagos bÿzodalmas Vraÿnknak, Isten utan nÿnchen kÿ hez remendko̊dnunk es essedeznunk hanem chak Nagsagtoknak: Touaba emlekezunk az mÿ nÿomorusagÿnkrul Nagsagtok ${ }^{2}$ eleoth, mellekrẅl $l^{3}$ panazolkodunk: Elseo panazolkodas hoǵ az eleőt mÿ nekunk nem uolt ket Ispanunk ha nem chak egy uolt, mastan kedigh kettö wagion, annak az egÿknek feÿet haÿtotunk es meg bechültuk, mastan ketten wadnak raÿtunk es elnek raÿtunk giakorlatos keppen nem elegezik egÿ pÿnt borual kÿwel tartoznank hanem beüsseguel hordat á borth az $\stackrel{e}{\mathrm{w}}$ uendeginek es egy pÿnzt sem adnac ${ }^{4}$ a borra, hanem az warasra uetik a naǵ kölcheget, kÿrul ÿol emlekezunk rola mÿnian(!) hoǵ chak haromszor eztendeo altal ${ }^{5}$ fel iòth az Ispan mi hozzank, mastan szuntelen ketten noÿmorgatnak benn̈unket (!) es nem gio̊zuk ẅket ko̊lchegeul.

Annak utanna ket Jobaǵ helt magoknak foglaltak es maÿorsagot tartnak mel Jobagÿok chaszar $\stackrel{e}{u}$ follsegeie uolnanak es annak utana kỏzunkbe nem engedik szolgalnÿ. Esmeǵlen zanto folldunket el foglaltak mÿ tülũk es oth szantyak ${ }^{6}$ hun szÿnte akarÿak. Az Retetÿs mÿ tulunk el foglaltak es oth kazallÿak hun keduelik es szeretik, kÿ soha nem uolt es senkÿ rola meg nem emlekezik. Azonkeppen uagion mi nekunk egy kÿchÿn weszo̊nek ualo tilalmas erdönk melly weszöth ${ }^{7}$ chak haz körül ualo epuletre tarttÿuk, aztÿs az Ispaniok hun akarÿak oth uagÿak az ù maiorsagokra, mÿkor kedigh mÿ nekunk szugseges uolna hat nÿnchen hun ${ }^{8}$ wagnunk.

Thouaba megis panazolkodunk Nagsatoknac es emlekezunk rola hoǵ minekunk uagion fogot wizunk kinek nag eros gatÿat tarttÿwk es naǵ munkaual epethůkk. Az Ispanok azt chelekeznek Barmot rea fogadnak itatnÿ es annak iutalmat az wiznek feöl uezÿk magoknak mely Jeouedelem szentegihaznak iarth mÿnd o̊rókkül es annak á iuldemebul (!) szentegihazath epetettenek megh, kÿt megh bÿzonethunk regi emberekuel hogi az Ispanoknak soha nem iart a wÿznek iutalma kÿrul mÿnd o̊rôkken emlekezunk iol.

Annak follôtte á thoo wizeth ${ }^{9}$ giakorta halazzak szinte mikor akariak akor haloiokat bele uetik melÿ keues halat benne tarthũk az feÿunknec menthsegunkre kibul az Tờốko̊knek fizetunk:

\footnotetext{
${ }^{1}$ Ebből javítva: ä̈alunk; az eredmény: aÿalynk, ami nem szándékolt alak.

${ }^{2}$ Javítva: Nagsagtoknak.

${ }^{3}$ Javítva: melleket.

${ }^{4}$ A -nac későbbi betoldás.

${ }^{5}$ Javítva: ala.

${ }^{6}$ Javítva: szanchak.

${ }^{7}$ A szóvégi $h$ toldás.

${ }^{8}$ Javítva: uagnunk.

${ }^{9}$ Javítva: wizek.
} 
Esmeglen arul is emlekezunk Naǵsagtoknak hoǵ az is to̊ruinunk soha nem uolt hoǵ azt akarỷak hog ů nekiek annÿ szolgalatot szogalÿunk mind az fôldes wrunknak, Aztis akariak hoǵ minden öth ${ }^{10}$ emebrtul egi egi kazast es minden ôth embertul egi egi zeker fath hoǵhaggÿunk azt kedigh keczer eztendeo altal kerik mel fath mÿs draga pénzen uezunk es mezÿ földrul horgÿunk magunknak is, soha nem uolt tơruinunk hoǵ Ispanak fath horgÿunk. Mert ezÿdenis á ket Ispan miat az $\stackrel{e}{\mathrm{w}}$ hazok chynaltatasa miatta mi ko̊zulunk uettetlen egÿ nehan ember karba maradot.

Thowaba arulis panazolkodunc Nagsagtoknak mÿnt bizodalmas wraÿnknak hoǵ fô fô embereknec mi kòzulunk nÿnchen semmÿ tiztesegünk az Ispanok eleöth sem iambor neuunk, kibul kerunk bochanatoth Nagsagtoktul Istenert hogi megh bochasson mi nekunk minemö rut undok bezeduel zidalmazã ${ }^{11}$ bennunket Beftia kurwafiaknak, ebeknek neuezi, es annak fơlette mongiak hogi' niakon fogua ala uizen mÿnt egÿ ebeket, es az tomloczbbe niakon uetlek. wywarban. ${ }^{12}$

Annak fölòtte nagÿub dolgokrul panazolkodunk Nagsagtoknak, megh nem elegettenek mind ezekrulis kit chelekettenek mÿ raitunk, ha nem nagÿubat mÿueltenek raÿtunk kÿth nÿakon kÿt arczul, kÿt wsthekue (!) az byrakba es á polgarokba wontanak. Es annak follotte chaszar $\stackrel{e}{\mathrm{e}}$ fôlsege ket Jobagiat megh oltek, az Ispan szolgaÿ mÿueltek mÿuta fogua $\stackrel{e}{w}$ ÿth az Ispansagot bÿriak. Mÿ az wduarbÿronk elôtte panazolkodtunk sÿruan ezekrül az mÿ nÿaualÿainkrul es ${ }^{13}$ egÿeb dolgaÿnkrul soha nem foghata el az wduarbiro weet mi rolunk. Az Ispanok azt mondottak nem paranchol az Wduarbiro mÿ nekünk nem $\stackrel{e}{\mathrm{w}}$ adta nekũk az Ispansagot el is sem uehetÿ mÿ tulunk ha ÿgen nehezetek es bannÿatok mennÿetek el kamarasokra posonba panazolkogÿatok es tegietek rola. ${ }^{14}$

Orőkke ualo szolgalatunkat aÿalunk Nagsagtoknak mÿnt bÿzodalmas wraÿnknak, es patronossÿnknac ${ }^{15}$ bÿzodalmunk uagion Isten utan Nagsagtokban Mÿ mÿnd feÿenkÿnt naǵ es kÿczÿn panazolkodunk Nagsagtoknak, kerunk es ko̊nie̊rgunk alazatos keppen mÿnt Nagsatoknac es wraÿnknak Isten utan. Hogy ${ }^{16}$ uegie el es fogÿa mÿ rolunk ennÿ sok terheket mellÿeket szenuedunk mÿatok az Ispanoktul, mert anekulis nagÿ ${ }^{17}$ Insegben uagÿunk es naǵ fÿzetesbe az kegietlen Tơrókôktul kit nem geozŭk sok adoual mel fÿzetes auag summaÿa tezen hat zaz forÿntoth melÿ sũmat meg kel adnunk $\stackrel{\mathrm{e}}{\mathrm{w}}$ nekiek: kerunk Nagsagtokat legien melletunk mÿnden ÿo elomenetunkre, es segetsegunkre Isten utan, m[ert] ha Nagsagtok erettunk nem zol es nem tamad es el nem ueszÿ mÿ rolunk az mÿ nÿaualaÿnkat az Ispanok miat kÿt zenuedunk Hat mÿ nekũk el puztulnunk kel. ${ }^{18}$ es

${ }^{10}$ Javítva: $\stackrel{e}{o t h}$.

${ }^{11}$ A nazális jel pótolva.

${ }^{12} \mathrm{Az}$ utolsó szót a javító írta.

${ }^{13}$ es beszúrva.

${ }^{14} \mathrm{Az}$ egyik lapszélen (Eckhardt Sándor megjegyzése szerint): circa festum beati luce 1580.

${ }^{15}$ Javítva patronosaynk-ból.

${ }^{16} \mathrm{Az} y$-t a javító írta.

${ }^{17}$ Az y a javítótól való.

${ }^{18} \mathrm{kel}$ beszúrva. 
el hadnÿ puztan wegreis, mert nem geozzuk Ispanokat is szolgalnÿ es foldes wrunkat is. Azerthan warÿuk Nagsagtoktul alazatos es mÿnden ÿo ualaztoth kÿbe megÿ ${ }^{1}$ maradando iouendore maradhatnank meg, es nagsagtoknak meg szolgalÿwnk ${ }^{2}$ mÿniaÿan, kiert az wr isten is meg fizet nagsagtoknak Az Isten aggion Nagsagtoknak mÿnden ÿo szerenczet naǵ sok eztendeigh ÿo egesseget, es bekesseget.

kegielmes walaztot warunk Nagsagtoktul.

Az tardoskeddi bÿrak, es eskuttek polgarok mÿnd az egez kôssegh Nagsagtoknak alazatosson aÿanliak ${ }^{3}$ magokatth. ${ }^{4}$

kapant

zait

Molendinum

Barant

fenum occupacio vinorum

Cenfus

Educillacio

Barmot tartnake

birsagium bitang

prandium

capecie

sekerezes,

Hatar

fatt

Artan

Bwza

Mezet

balasi miklos in conspectu Provisoris vsteken fogta keowe [...] asert hogj nekj panaszlot Arewl verte, oth solgaiwal meg fogatta, vgi verte hogi fekut bele tjz hetig 5

Esen Miklost Miklossi Janost vsteken fogta atsig verthe mig akartha mjnden ok vetetlen Eseket meg bwntetek terwenjel ${ }^{6}$

Suplicatio colonorum Taroskedd contra Nicolaum Balassa Officialem.

\footnotetext{
${ }^{1} y$ toldva.

${ }^{2}$ Javítva: -nank.

${ }^{3}$ Az $i$ beszúrva.

${ }^{4}$ Az utolsó szót a javító toldotta hozzá.

${ }^{5}$ A lapszélen.

${ }^{6}$ A lapszélen.
} 


\section{II.6.}

Kissár, 1580. Kissári jobbágyok levele.

Mÿ megh Nẏomorultak, es megh keserettek Zeginiek, kÿs Saraÿak, kÿuaniuk, az Hattalmas Istentul tÿ Nagisagtoknak, mint kegÿelmes Vrainknak, minden testi es leölky, aldomasokat, es ez wilagon walo hozu, eletteket mint kegÿelmes Vraÿnknak megh adattni.

Towaba, mi megh niomorultak, Az egi megh valto Vr Jesvs Chrusert, ezen nagj alazatosson keoniergunk tÿ Nagitoknak. Hogi tÿ Nagtok, az my sÿralmas es alazatos kenoiergesunket kegielmesen halgasa megh. Mert minekunk, Isten vtan ninczen kÿhez teöb, itt ez niomorult vilagon niomorusaginkban foliamnunk Hanem cziak tÿ Nagisagtokhoz.

Legelőzer azert, ebul panazolkodunk tÿ Nagisagtoknak nagj sÿralmasan: Mint hogi enek elotte. az minemeo Igasagos tÿzedel tartoztunk. Jozagunkbul, kÿtt az regi Istenfeleo feÿedelmek rendeltek wolt keözÿnkben, minekunk az felöl. illen eleö teöruinÿunk wolt: hogj eztendeonkjnt. minden Jozagunkbul kelet kÿ adnj. Vraynknak. azt penigh harom rendbeli Jozagal kelet be telesitenunk, ugj mint Buzaual, Rosual, es Zabbal, ez penigh vgiā eleo teőrǔiniunk uolt: hogj azt. chiak Vÿwarban kelet be zolgaltattnunk: Mostan penigh ez mj mostanj Tÿzt tarto Vraÿnk, ebulÿs kÿ weöttenek benunket, es el niomtak az regj Igasagonkat: semikepen nem elegeznek megh azal az igaz imar. Hanem anak feöleötte, mind az tyzedet es kÿlenczedet megh vezÿk rajtwnk: Eztÿs harom felewel <wezÿk> nem vezik. az mint az igaz volna, Hanem imar az Ros helett mind bǔzat veznek raytunk: Annak fölötte ha cziak azal, elegednenek megh iol wolna: De kett anira rounak benunket az mi az igaz volna; az mÿ az igaz anak kÿüle: Is megint ezýs eleö teöruinyunk wolt. Hogj mihelen el wegeztünk az aratast, zabad wolt Jozagunkat be hordanunk, czepelnunkÿs zabad volt az kÿttul lehetet wettesere. De azttÿs semikepen nem engedik mostan, Hanem nagj ereős bÿrsagh allat ebwlÿs kÿ weöttenek benǔnket. Annak utana az Dessma allat az Jozagh felol, megh Eskutettnek mindeneket, azal is imar nem elegeödnek. ha hÿtth zerint megh mongjuk, Jozaginknak zamat. Hanem mind az feölött, ket anjra Irÿak hogj nem mint az desma wolna: Towaba erulis nagj syralmason Panazolkodunk Nag̃toknak: Hogj mi anak elötte nem tartoztunk ezel, az Tyzttarto vrainknak, Hogj az Dessma Jozagot. Idestoua hordotunk wolna nekÿk. Vgi mint azt az kÿ mas faluban, mas hattaron termet: Hanem cziak mi magunk Desmaÿawal, az kÿ mi tw̄llunk iǔtot nekÿk, azt tartoztunk Vÿwarba be wÿni. Mostan imar nem cziak mj magunket ezek, hanem megh mas falubelÿttÿs, Hol praznoczra hol Nagj Zombattba, hol Zerdehelre Vÿttettÿk bott allat velunk: kÿ miattÿs menie Insegunk wagion vgian meg nem tugiunk megh mondanj Nagitoknak.

Annak fölötte. ezÿs nagj niomorusagunk eztendeőnkÿnt: Mert anak elötte: Nem wolt az teoruiniǔnk Hogj az tÿzt tarto Vraÿnknak, mi $<($ nem $)>$ tartoztunk 
volna $^{1}$ fa hordassal, varta fawal sem tartoztunk. Kapitan Vrunknakÿs nem tartoztunk fa hordasal. De mostan anj niomorasagunk wagÿon miatta, hogj mind tÿztarto vrainknak zakadattlankepe kel hordanūk: Vartara azonkepē. kapitan vrunknakis zÿnte ugj, ez penigh megh zamlalhatattlan eztendő alltal, kÿ miat ha teöb zolgalatunk nem volnaÿs megh sem geöznenk, mert ez eÿel napal Job rezere raÿttunk wagion, Ha penigh panazolkodunk felole tÿzttartoÿnknak: eök ugjan azt mongjak hogj semit nem gondolnak wele. Azert giapiunkat el nÿrÿk. ottalomal nem akarnak lenj. Mert ha zolunkÿs nekjk hogj illen gondwiselettlenek, eẃel foÿttnak benŭnket, ha nehezed. mond megh bator vduarbÿronak, semjt nem gondolunk vele. Mert nem vduarbÿro, hanē eo feölsege adta enekem az tÿztet, azert bÿrlak. megh bÿrhattlak.

Ismegint erulÿs nagj panazunk vagion Nag̃toknak: Eleỏ teőruinÿunk ezÿs wolt, soha anak elötte kazast mi nem adtunk az tÿztartoknak: De mostan ezek eztendeö alltal zÿnten, anjtt kazaltattnak velunk az menÿe kel: Hanem cziak kazalo pinzel tartoztunk. az Czÿazar zamara, azt azert ugjan mostanÿs megh aguk. Lohattÿ Ispanok mÿattÿs, illen nagj kÿnūnk wagjon, anak elötte, mi semmiwel nem tartoztunk nekÿk, mostan imar vgjan raÿttunk elnek, ittalt es ettelt mindenkor eleget kel adnunk nekjk: Azal nem elegeznek megh, hanem mideön walameli fele akarnak menj. az lowat ott raÿtttunk hagja, eö maga alla koczytt kel adnǔnk, es zÿnten, ott hordoztattÿa velunk magat, ahol akar, az mellet penigh vtalatos dologh az menie Zydalmat teznek rajtunk.

Towaba az tÿztarto vraink ezttÿs, czelekeöznek raÿtunk. Mikor az Heǔwÿzben akarnak el menÿ. Inen kyw̌l welunk zekeret. louastul vẏttettnek be. azon wÿttetti magat, ha haza akar Jünj. Ismegint erettek fel kel menunk. azert efelebul sem tartoznank nekjk zolgalatal.

Vyzontakssagal az lohattÿ Ispannok, Ezelÿs niomorgattnak bennunket: mert anak elotte illen teorǔẏniǔnk wolt. Hogi mideon valamj panaz esset, keözeöttunk, annak lilen teorǔinie wolt, Ha panazt teöttek az bÿro elött: anak bÿrsagad 40 pinz volt: Ha keket mutatot. Hattuan pinzen marat. Ha vert 80 pinzen. De mo tan.ebulis kÿ veottenek benunket; mindjarast. uagj wagion panaz auagj nincz, ugjan egj forintot vezen. sem teöruinttul. sem Igasagtul nem var. Aanakis regente kelett volna harmadanak lenj. az Bÿronak de ök most semit sem adnak: Azert ebulÿs megh ertthetÿ Imar Nagisagtok Nyomorǔlt allapatǔnkat, Mert minekunk sem feõldǔnk sem erdeõnk nincz: hanem mind mas Vr feolderůl elunk. Feöldeőnk penigh, cziak anj wagyon, hogj harom nap megh •zanthattya, egj eke. egj hel utan valo feöldet, anj zukeőn wagion keőztǔnk. azert az zolga lat minden nap eöregbedik abul semj tagulasunk nincz. Hanem Nagisagtoknak, ezttẏs akarnak tǔdtara adnj. M'uel hogj. anj zŭk foldeonk wolt elejttul fogwa. volt itt. melettunk, vgj mint k`s Saro es Nagj Saro keözeőtt: egj Nemes puzta Helli: Az Vssalÿ Peter Vrunk megh vettete volt velunk Myüel, hogj ani zǔk foldünk. volt, mert egj felöl. Nagj Vezeleÿ hattar,

\footnotetext{
${ }^{1}$ Beszúrás.
} 
zÿnten falunk mellet wolt, mas felöl. Nagj saraÿ hattar, ezek miat ugjan egj felöl sem mehettet wolna marhank, ha azt az puzta Nemes helt megh nem veottunk volna. Mostan imar az Nagj Sarajak, vgjan tulajdon pinzen veött saÿat, eöreök feőldǔnket, el veöttek tẅllunk. Jolehet eleget panazolkodtunk felole tÿzttarto Vraÿnknakÿs, hogj ne hadnanak benunket igasagunk melet, De wgian semit nem gondolnak velunk Es semj gondunkat nem wiselÿk; Azert ha tÿ Nagisagtok ebüljs el felettközÿk rolunk, Mert minekunk nÿnczen mar Isten utan kÿheöz foliamnunk, ugjā el kel puztulnǔnk. oka ez mert nincz Isten uttan ottalmunk: foldunk sÿnczen, kÿwtan kelenek magunkat taplalnunk. (Jolehet hogj az egj Isten taplalonk.). Mind azon alltal, ugjan eleget futostunk, idestoua, igasagunk melet, mind Zolga bÿroual tÿlltatunk, reÿaÿok vÿttunk, magunkis tÿltotunk, de ugjan semmj igasagnak nem akarnak hellt adnj. Vgian fel zantotak mind ezek elen saÿat feöldunket. mosstanis ellÿk. illen teorǔÿntelenseget czeleköznek rä̈tunk ezekys. Towaba ugjan ezen Nagj Saraiak: illen dolgotis czeleködttenek raÿttunk, saÿat örõk feõldeõnkeõn, egj emberunket megh fogtak, bw̌ntelen, zekeret el fogtak alola, Harom forintban ittak, ezt penigh nem egj emberunkeőn teörttint, hanem teöbenys. nem eczer penigh hanem enihanzor: mert senkjttul semmi felelnek nincz, megh ha zolunk felóle nekjk vgian eỏ magok newettik benunket, hogj Vrunk ninch.

Touaba tÿ Nagisagtoknak efelölis keőniergunk: Hogi mint annak elötte, az minemeo elo teoruiniunk volt, Hogi mideön az czÿazar borat adtak keözÿnkben: Legh elözer adtanak 6 ako bort azt penigh Zent Geörgiekel egiut kelet megh fÿzettnunk: Annak utana Ismegint Vssaly Peter Vram: illen dolgot zaba keözÿnkben. Haromzor vettet vr borat eztendeo allttal: aztt is minden eztendeobe megh kelet fÿzetnŭnk Mostan imar miuel hogj az Vr Isten illen zŭk draga ideöket, adot keözÿnkben, mind borbul es kÿnierbul. zuksegh volt. Czutor Jannos vrunkkal illen kepen enihan eztendobe vehettǔnk volth, miuel hogj az bor zukýs volt zeginis. azert erre kerttunk volt hogj bortt ne agjon keözingban, hanem minden eztendeöben, 12 forintot adtunk $<\mathrm{w}>$ twlle. miue hogj kewesenÿs uagjunk, mert puztaual egjetemben. teöb Helunk nincz, hanem cziák tÿzenket hel. ezt vgjan Hẏttunk zerint valunk Nagjsagtok elött. Azert Nagisagtokat, az egj Istenert kerunk Hogj tÿ Nagisagtok. kegjelmesen tekÿnttuen az mj sÿralmas keonergesunkre, engegje megh Nagisagtok, ugjā ezen tÿzenket forintban. az Vr boranak dolgat, Hogj eztendeörul eztendőre azt adnank. kÿert mÿs Nagisagtokert lehesunk Isten Imadö̈. Ha megh maradok lehetǔnk ez niomorult helben.

Ismegint effelolÿs Panazolkodunk tÿ Nagisagtoknak: Mÿwel hogj minekunk. Erdeönk nem wolt eleÿttul fogua az mi feoldeőnkeőn, mostan sÿncz: Hanem az Zentt Geőrgjekel, illen teőruinyunk wolt. Mÿuel hogj mind egj tÿzt alla walok wagionk. Hogi valahol az zent Georgj embernek zekerczeÿe, el ment . az mi falunkbeli embernekis zabad wolt ott wagni, es ha cziak kett zal $<$ fall $>$ fa wolt wonaÿs, ha reÿa erttǔnk, annakÿs mienk wolt egike, az masika eőnek, ezt penigh vgian toeruiniel nÿerttunk wolt megh, mÿuel hogj eleÿttul fogua ugj wolt kyrul nagj erös bÿzonsagunk vadnak mosstan is. Mo stan imar. semikepen nem engedÿk, 
ewel wezÿk eleÿtt, hogj imar el keőlt az, az teőruinÿ, mert mi ugimond teöreoknek zolgalunk tẅlle. Imar mostan ugian el tÿlttotanak bennǔnket tẅlle, ugjan nem engedik. Az Rett eoreoksegbulÿs zÿnten $<$ igj $>$ illen teőruiniunk wolt, azÿs mindenkoron zabad volt, minekunkÿs, mind marhajnknak azt sem engedik most. Hanem bÿrsagal feniegettnek bennǔnket, ha reÿa megiunk. es kapan nemeö aÿandekot kÿŭannak raÿttunk, kÿ soha nem wollt, nemis tartoztunk, nemis adtunk, az mint megh latthatya Nagisagtok, minden mi Igasaginkot. az Zent Albert keonuebe.

Annak folötte Hÿttunk zerint vgian ezttÿs vallunk: Hogj az mj labas elö marhank zinten ott jart ahol az Zent Geörgj, mind elejttul fogua, azert ebenis nem tarttnak benunket, megh cziak az Zomzedsagaÿs, miuel hogh nincz kÿ meletunk fogna.

Vegezettre ereolÿs panazolkodunk Nagisagtoknak: Hogj ebulis nagj niauaÿank vagjon. Mert mi nekunk enek elötte illen eleo teǒrǔiniǔnkÿs volt: az mint mostanis Zent Georgjeknek es Fẅzes Gyjarmatiaknak. Hogj mÿ sohol anak elötte vamot nem adtunk, valahol Jartunk zabadon mehetunk. De mostan mindenut megh vezik rajtunk; Jolehèt azert megh lewelŭnk kezŭnkbe volt, nem adtunk. De miuel hogj az zegin falu ecczer mind megh egett wolt, azert Levelunkÿs akor wezett el. azutattul fogwa mindənut megh wezik rajtunk. Hanem Nagisagtokat az egj elõ Istenert kerunk hogj Nagisagtok ne Hagion megh niomorodnǔnk, mint hogy Nagisagtoknal wagjon minden mi Igasagunk. azert az melet legjen mellettunk Nagisagtok. ne Hagjatok. Mert ha Nagisagtok. Isten utan gondonkat nem viseli, ez sok insegh mÿat. el fogiatkoztǔnk. ugjan nem lehettunk enek utana. Nagisagtok Jobagj. el kel buidosnunk, mert nincz Isten utan giamolunk sem ottalmunk. kj rajtunk keőnierulne. Vgjan meg valiuk Naḡtoknak. hogj megh nem alhatiuk, ez nagj inseget: Azert Ha Nagisagtok raÿttunk nem keonierǔl Isten vtā. tehat ereÿs kerunk Nagisagtokat. Hogj Nagisagtok agjon minekunk ollj zabadsagot. ahol kÿ feÿett ottalmazhattÿa ottalmazza: Nagitokat az egj Istenert kerunk Hogj Nagtok meg bocziasa hogj enj Irasunkal vntattÿuk Nagisagtokat: Nÿncz mitt tennunk, mert Isten vtā nincz gjamolunk egjeb Nagissagtoknal. Azert alazatoson kerunk Nagisagtokat Hogj Nagisagtok agjon mind ezekre minekunk niomorultaknak ${ }^{2}$ kegjelmes valaztot. Ezel egjetemben penigh az eleo Istennek ottalma es vezerlese alla. aÿanliuk Nagisagtokat. mint kegjelmes Vrankat.

Mi meg Niomorultak es megkesserettek. kys Sarajak.

Tÿ Nagitok. Zegin Nÿomorult aruaj.

Supplicacio Humillima

\footnotetext{
${ }^{2}$ Javítva ebből: niomorultakat.
} 


\section{II.7.}

Felsőbánya, 1581. I. Felsőbányaiak levele.

Generosi ac Egregÿ Dominj et Patronj nobis semper Graciosissimj etc. Post fideliu[m] Seruitior[um] nostror[um] humillima[m] com[m]endationem etc.

Mÿert hogÿ Immar sok Ideotewl fogwan az zÿksig fellieb fellieb neuekedett raÿtunk, es mindenfele allatnak dragasaga reÿank keöwetkezett, leg inkabban penig m reÿank kyk fęl felę az orzagnak ziliben mezze lakunk: Melÿ miatt az mÿ baniazÿ iletwnk felette igen meg bantatott, wgÿ anniera hogÿ Baniaÿnk miuesek nekewl wezteg alnak, es az mit panazolkodaskệppen Vrasagtok eleott egÿ nehanÿzor mondottunk, hogÿ az mÿ heliwnknek az Bania miueltetisnekewl pwztaban kell maradnia, annak kezdetÿ es bÿzonios Jelensige Immar nÿlwan wagion; hogÿ Jeowendeoben wgian nem reminlhettiewk hogÿ ew fel[si]ginek haznot adhassunk es eo fel[si]ge wtan mies éppen meg maradhassunk: Mert noha V[rasag]tokat nagy sokzor wgian teliessiggel el wntattuk az keoltsigért es Vrasagtokes az menÿre lehetett az ew fel[se]ge sok kÿleomb kÿleomb fęle zÿksigeÿtewl, meg segitett, de az Baniaknak miueltetése fellieb es bÿwebben kÿwanta wolna az segitsiget,

Ez dolog feleol akartuk V[rasag]tokat meg keresnÿ, hogÿ Vrasagtok tekintene meg az mÿ niomorult allapatunkat, es talalna Vrasagtok olÿ modot benne, hogÿ az ew fel[se]ge Jeowedelme se kewessebbewlne meg, mies ennel inkab el ne pwztulnank, Mert zomzédsagunkban az Erdelÿ waÿda kazdag Bania miuet Indétott Kapnÿkon es Laposson. az ew Jozagaban, bew fÿzetést tézen reÿa, miuesewnk oda takarodik, es az miatt naponként hatrab hatrab maradunk. Ennek eleotte walo Ideoben penég mikoron eo fel[se]genek penze nem wolt keozeottewnk, az Zakmarÿ kapitanok reÿa zabaditottanak bennewnket, hogÿ az mÿ iletewnk rendÿ zerint, (holott sem zanto feoldewnk se zeoleo hegiewnk ninchÿen kÿ wtan ilhettewnk wolna) legien zabadsagunk az mÿ keresmeniwnkbeol ilnewnk, ez wégre hogÿ az Baniak el ne pwztullianak: hanem mikor eo fel[se]ge pénzt rendel keozinkben ackoron lehesswnk alkolmatosok az Baniaknak miueltetésire, mert az baniaknak wagÿ wezik haznat awagÿ nem, de zÿntelen meg kÿwannia az éppitést, wagÿ sattia wagÿ Istollia hogÿ be ne romollion, az wÿznek kÿ wonasat azonmodon, hogÿ wÿzwel meg ne tellienek.

Annakokaÿrt keonieorgewnk Vrasagtoknak, mint mÿ welewnk Jol tÿweo kegÿ[el]mes wrainknak, es Atiainknak, $\mathrm{V}[\mathrm{rasag}]$ tok talallion olÿ modot benne hogy az minemew Bania eoreoksigeink reÿank marattanak az eleynkrewl, warasunkwal egietemben pwztasagban ne maraggionak, V[rasag]tok kegy[el]messigibeol tegie het forintra az Ezewstnek gÿraÿat, mint ez az teob Baniakon Selmeczen es Kremneczen, es az probat, melÿ mind ew fel[si]ginek smind mÿ nekunk hazontalan, wegie el rollunk, es az tÿzta somancz ezewsteot wgÿ engeggiewk egÿnehanÿzor walo tewzwel meg tÿztitanÿ, az mint zinte az Igeteo es walazto akarÿa, kiben semmÿ Idegen allat, sem on sem rez meg nem maradhat az tewz miatt. 
Az wagÿ ha ew fel[se]ginek es V[rasag]toknak teczik, haggion zabadsagot V[rasag]tok ket eztendeig, hogÿ eppewlhessewnk ew fel[sé]ge es az V[rasag] tok kegy[el]mes engedelme wtan, mert felette igen meg fogiatkoztunk ez néhanÿ eztendeokban, fewképpen ez el mult ket eztendoben az Baniak keozeonsiges Istollianak meg eppitise miatt kÿre ew fel[sé]ge soha chÿak egy pénz sem wolt (!), hanem az mÿ saÿat keoltsigewnkwel éppitettewk, Nem wgÿ mint Nagy Banian, holott chyak zinte az ew fel[sé]ge keoltsigiuel, nem az ew keoltsigeckel az Baniazok eppitik az Baniaknak Istolliat, Mindazon altal, hogÿ ha Vrasagtok olÿ derik segitsiggel lehet, kÿwel Baniaÿnknak miueltetésit fel irÿewk, Igiekezewnk raÿta, hogy walamit az wristen az eo Jo woltabol munkank es faratsagunk wtan ad, azt hÿwen es haznosson be zolgaltatassuk az ew fel[si]ge kamaraÿara kit miis Vrasagtoknak nagÿ halaadassal zolgalhassuk meg: kÿrewl Vrasagtoknak minden kegielmessiggel walo walaz tetelit warÿwk:

Isten Iltesse es algia meg V[rasag]tokat minden Jouaÿban.

G. ac. Eg: D. Vestrarum fideles et humillimj Seruitores Montaniste oppidj Medÿmontis etc.

Humillima Supplicatio Montanistars[um] Felseo Banianien[sium]. 


\section{II.8.}

Felsöbánya, 1581. IV. Felsőbányaiak levele. [részletek]

[...] Mÿert hogÿ az feiedelmeknek miltosga es fel[si]ges wolta abban magaztaltatÿk, hogÿ az ew alatta waloÿ terÿeggienek sokasullianak es eorwendezwin Illienek kegÿ[el]messigibeol nekiek engedett Jockal, Ezt meg tekéntwén az mÿ régÿ feiedelmink engettik wolt minekwnk, hogÿ walakÿ keozzewlewnk wÿ, awagÿ régÿ el hagiott pwzta Baniat, wagÿ Sattot nÿtna, es éppitene Kapnÿkon, niolczeztendeig wenne el az haznat $[\ldots]$

[...] Kÿz Baniara, Sloÿorra, es az varas felett walo keozepseo hegyre [...]

[...] az Jobagiok ottan el mentenek mert chÿak bwdoso olahok woltanak, wgÿ anniera hogÿ immar zinte harmadik helÿre keolteoztenek, es mostannis haromnal teobben nem wadnak, kinek zallétasanak wagion hwzoneot eztendeÿe, Ezekis penég nem azok az kik leg eleozeor meg zallottanak hanem inkab negied wagy eoteod rendbeliek, ew fel'ginek semmÿ meg chyak egy fillier Jreo haznalattiara sinchÿenek [...] 


\section{II.9.}

Dorog (Nánás, Varjas, Vid), 1582. Dorogi jobbágyok levele.

Szolgalatunkat aianliuk Vrasagodnak mint bizodalmas Nemes Vrunknak es kiuanunk Istentwl minden iokat te Vrasagodnak.

Touabba mielhog bizonios es kiualkeppen (!) ualo szwkseges dolgaink felól kelletek mostansaggal meg tanalnünk Vrasagodat keriwk azon Vrasagodath hogi meg botsassa Vrasagod ha ielenletelwnkel meg bantatnek. Keoneorgeswnk peniglen errwl uagion Vrasagodnal, hogi az mi nemẃ ioszaga Czaszar w felsegenek Tiszantul uagion ugi mint Dorog, Nanas, Varias es Wid tuggia aszt vrasagod mellí niomorulth helien es allapatban legien fŭkeppen az Tórók miatt melli azon ioszag naprul napra egi okonnis masonnis egi. eset miattis mas miattis houatouabb mind nagiob niomorult allapatra iuth. Teob wnsegik kozeott mostansag ez igen terhess tisztelendeo nemes Vrunk hogi az melli Ispan mostan az ioszagban uagion, kinek Benedek Deak Neue szertelen keptelen dolog az menj sattzoltatast teszen az falunkonn az okonn, merth tart tizen hat szolgat kiknek mind maguk szwksegere ualot es mind louokra az szegensegen szagatnak es nagi sok keppen uagion romlasara az szegen ioszagnak. Annakokaerth minth hogi annak elotteis az mikor affele szolga kózeottwnk nem uolth szinten ugian meg tellesitettwk ha mi parantsolath czaszar w felsege emberjtwl iótt ualaminth szinten eronk uolth rea; mostann kóniorgwnk vrasagodnak hogi ez mi wnsegwnketh meg gondoluan uegie el rolunk vrasagod ezt az terhet ne kellessek szertelen ualo niomorusagra iutnonk es a helrwl el oszlanwnk. Ezfelett az minemẃ barom morhanak az mi mezejnkre ualo rea botsatasatul az szomszedsagbeliek fizetest tesznek abbulis azt kiuanio ... hogi szenth Mihalj $<$ Georgh $>$ naptul foguan szent Georgj napig w neki aggia az eggik falu $<$ Vid $>$ Varias az mi affele fizetes iwne, mely fizetest az szegen heleknek hasznara tartanank.

Vegezetre vitezleo Nemes Vrunk mj az kik Putnokj Boldisar szerjrwl az Czaszar w felsege feóldere mentwnk uala, viszont azon elebbi hazunkba melj az Putnokj szerin uagion az Tokaj Vduarbiro parantsolattiabol uissza mentwnk es onnan szolgalliuk czaszart $\mathrm{w}$ felseget mielhogi penig mostannis igen feneget bennẃnket Putnoki igen felwnk meg niomorgatasatul merth ennek elötteis nagi kart uallottunk es niomorusagoth miatta, nem tellesseggel tuggiuk mihez magunkat tartani Annak okaerth koniorgunk Vrasagodnak hogi aggia erteswnkre Vrasagtok ha kelle ualami bisztatast Vrasagtoktwl uarnunk hogi arra ualo kepest tuggiunk mihez tartozni.

Isten tartsa meg Vrasagtokath.

Iidem qui supra v[ide]1[ice]t incolae

Dorog Nanas Varias Vid

supplices 


\section{II.10.}

Vámospércs, 1584. XII. 9. Tokaji jobbágyok levele.

Kgdeth minth bizodalmas nemes Vrŭnkath azert kenzeritetenk <keog> keŏniŏrgesw̌nkel megh talalnŭnk hogj ez el mw̆lt napokban Horüath Matias Vrwnk itt az tizeden leteben, emlekezenk $\breve{w}$ kemenek az mj el szenŭedhetetlen nagj kin es haborw̌jnk feleóll, mellÿeketh az vegh belj, ügy minth Zathmarj, Eczedj, Kallaj, Vardaj, Thokaj es Egrj Nemeth es Magiar üitezek miatt el szenŭedŭnk, vgÿanÿra hogy orankenth szw̌netlenek rajtw̆nk, louaikath hazw̆nkban keóteózik, Abrakot nem adhatüan büzainkath etetik, borainkat, eletw̌nketh tekozlÿak, vgÿ anÿra hogj egj be szallassal 9 Rfl rā bort el hordatnak, czak egj penztis erette nem adnak, Az bortwl megh reszegedüen hazainkbw̆l magw̌nkath kj ŭernek, feleseginkel be rekezkednek, Isten ellene w̆ndok fertelmes dolgokat, bw̌̈asagoth, tobzodast chelekednek, kiketh immar semmikeppen nem szenúedhetw̌nk. eddegis czak Isten üolth gond üiseleőnk: kerÿw̆k azerth teh kĝdeth minth vrŭnkath, hogj teh k $\bar{g} d$ legh eleószeór tekincze az Istenth, es annak üthana az mj szegeny niomorülth üoltw̌nkath, teh kg d keónioórgesewel talallia megh felseges chaszar $<$ sz $>$ kepebelj Groph vrŭnkath, $\breve{w}$ Naga <czak> czelekeggÿek kegielmessen ŭelwnk, es ez fele ketelensegh tew̌oketh fogion el $\breve{w}$ Nagz rullw̌nk, kith az Isten fidessen (!) megh

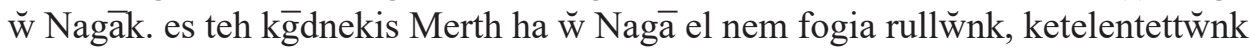
pusztan hadnw̌nk az szegenj faluth, az magw̌ [nke]th ott oltalmaznwnk, ahol $\breve{\mathrm{w}}$ félsege oltalmat ad.

Az $\mathrm{Vr}$ Isten algia megh $\mathrm{kg}$ deth minden Jauaiban.

Az 9 Rforint arra bor el hordatasanak oka uolth Radicz Benedek Kallaj: Az hazbwl kj űeresnek oka Pribek Mihalÿ hadnagsaga allat ualo Kalmar Benedek Szatmarj.

E. D. V. Sübditj

Ciues vniüersj Vamos

Peczienses

Supplicatio hümillima ad E. D. Prouisorem Thokaÿensem 


\section{II.11.}

[H.n.] 1588. I. Földvári Miklós levele.

Ez el mult napokban Bocỷatam vala kÿ szolgaimot vgj mint az helinek az w: mogia es szokassa szerint az vthakot alllanẏ az hol w: felsiginek hasznot tallalhatnanak mind az altal talaltanak volt valami Buszat az turczy் foldon melliet Contrabondalhattak volna w: felsige szamara vtbais voltanak velle de el mentenek az turczy் olhahok melỳ olhahokat szabo ballasz say்gay் Ballint es Surany் Gabor Bỳr segitsigul athak magokot az maramorossiaknak es el vottik az Contrabantot tullok vket annak felette penig igen meg vertik es vagdaltak Aszirt kegielmetteknek keoniorgok hogi kegielmetek irna az fellul neueszet szemilleknek hogi az iobagi felol alatnank toruint mert ha czýak hallgattasra veszend ez vttan nagiobat probalnak az w: felsige harmincyjadgian ki miat $\mathrm{w}$ : felsige prouentussa kissebedik es magunknakis giallaszatunkra < vagion $>$ liszen meli dolgot kegielmetteknek mint patronus Vrainknak meg zolgallunk...

Az kik Nagj Istuanra es Nagj Palra tamattanak Thurczon. ${ }^{1}$

Ket Molnar Janos Molnar Simon fiaj

Radoly Peter: Ezek Balint deak iobbagÿ

Radoly Demjen

Radoly Janos szabo balas iobbagÿ

Fatulÿ Kozma

Oroz Waszko

Neste Markus

Kolbaz Janos

Kolbaz leórincz

Lazar Simon Suranÿ Gabriel iobbagy

Tharsolcz: Bele Janos cziaszar iobbagia.

Ezeket hites emberek mondottak kj falujul

${ }^{1}$ Más írással. 


\section{II.12.}

Miskolc, 1588. II. 28. Sajótúri jobbágyok levele.

Ez dologrol kölletek vrasagtokat megh tanalnunk keónyŏrgŏ leuelẅnkel, mostani idŏben, ez el mult mass holnapban teórtenek az mÿ biro vrunk megh halnÿ, kitt tisztessegesen el teömtwink, vgian azon napon, Vduarbiro vrunk minden morhaýat ualahol mÿ uolt mindent el foglaltatot hozza mentw̌nk keòny்ergenÿ, hogj miert czelekezj raitunk azt kj soha ennek eleötte teórueniwn'nk itt az mÿ szeghen falunkban nem uolt, hogj az meg holt ember morhajaban bele ragadgion, teóruenre halazta akkor az dolgot, ez alat penigh az terónen kjuo̊l, etsaka borait el uitette, tudnÿa illik 11 borat, keỏnÿorgw"nk azert Vrasagtoknak hogj Vrasagtok ez ektelen dolgot raÿtunk ne hadgia czelekednÿ, mert szegen megh holt biro vrunknak sem szakatt mindenestw̋l fogua nemzetsege, hanem Attafjara marat, ha uelẅnk igj czelekezik az mint mast az teörök mÿa el budostŭnkis haza sem megiwnnk illien teöruentelensegtul

Ennekokaert meghis kónÿorgünk Vrasagtoknak hogj Vrasagotok ez dolgot az mint, teòruenre halaztot, nincz mitt tennẅnk, teóruennek allunk, mert ez ado fizető ÿobagj, soha czak egj oraigh sem uolt szabados, sem szokó sem budoso, eò magais szegen megh holt birank testamentomban mindent kinek kinek mind megh hagiott, azert ez szeghen nÿomorult falunak allapatiat megh tekentuen, czelekedgiek minden ÿot Vrasagtok uelẅnk, hogi mÿs lehessw"nk Vrasagtoknak, az szzegenÿ faluban lako ÿobagiok, Ehözkepest hogj tiztartonkat igj reank boczatta kegielmetek semit haza menetelen nem erölkódẅnk. Isten tarcza megh Vrasagtokatt. sok ÿo esztendeigh.

Kegielmes Valazt varunk vrasagtoktol.

Mÿ szegenÿ, falubol ualok Sajoturbol ÿobbagÿ vrasagtoknak.

Keőlt Miskolczon, vltimo feb. 88.

Ez leuel Adassek, Cassai kamoras Vraknak, mineukw̋nk kegielmes Vrunknak, tulaidon kezekben 


\section{II.13.}

Tarcal, 1588. III. Kovács János levele.

Eőrőkke ualo es hiuseges Zolgalatunkat aianliuk Vrasagtoknak minth eö felsege utan kegielmes io akaro patronusinknak.

Alazatossan kőniőrgiwnnk Vrasagtoknak, tekenchie megj Vrasagtok ez mostani Nagj zw"ksegben ualo fogiatkozasinkatt, vrasagtok adna megh im maran az borok arrat, merth anni era iutottunk hogj sohonnan semminek nem tuggjuk szeret tennj, az zegenisegis Chiak mÿ reiank kyatt erette hogj mÿ nem iarunk erette, ez penig megh soha nem uott hogj eggiknek az arratt megh nem attak uona, hogj az mas eztendõre ualotis ell szettek uona, hanem chiak most kezdi Vrasagtok.

Az Vur Istenertis keriw"k Vrasagtokatt, Vrasagtok im maron tekenchie megh niomorult allapatunkatt merth mÿ igj nem tudunk houa lenni, hogj szetten, ell szedik s az arratt soha megh nem aggiak, hanem Vrasagtok aggia megh mind az taualinak, smind ez ideỷnek az arratt, neh kellessék az szegensegnek Zőleiekett el szalagositani.

Ezennis kőniőrgw̋nk Vrasagtoknak, Vrasagtok uysellien gondott ez Zegeni Varosra mert sokan uadnak kőzzw̋lwnk, kiket ö felsege megh nemesitett zemelieben es nemelj kőzzw̋lók iktattais magat, tudni illik Hew" Palne, az mint ertiw̌k az tőbbis igiekezik rayta hogj uegheze uigie, ha ez igj lezen az tőbbis az feő nepek azon igiekeznek ualamj modual zerett tehetik, hogj ókis megh zerestessek, mj dolog ö felsegenek nagj karara essik, mostis uagion eő felsegenek nagj karara.

Balassi Balint Vram Zolgaÿs kik Zombort laknak, naponkent be iónek ez uarosra kit zidnak, kit ölesuel feniegetnek, czegertis leuagnak, ha Vrasagtok meg nem otalmaz bennw"nket mÿ nekw"nk megh kell romlanunk myattok. kegielmes ualazt uarunk Vrasagtoktoll.

Az Vur Isten, az eő őrőkke iauajban rezeltesse Vrasagtokat mind őrőkke s. mostan is

Tharczalj feöbiro Janos Kouachs

mind az egez Varosuall egetemben hiuseges

Zolgalattiat aianlia Vrasagtok nak, minth

kegmes io akaro patronusinknak eő főlsege utan.

Humilima Suplicatio Tharczaliensium. 


\section{II.14.}

Hejce 1588. VII. 20. Hejcei jobbágyok levele.

Vrasagtoknak walo zolgalatwnkoth Aianliuk

Vrasagtoknak czÿak erreol kelletek Irnŭnk mÿnt mÿ nekŭnk gond wiseleo wrainknak: keonieorgeottŭnk walo wrasagtoknak ennek eleotteis, az heczej mezarosok dolgabol, kÿkteol, az megh holt Wngnad Wrŭnk ideiebennis hordottanak, az kohniara hŭst, Wngnodne azzoniom it leteben azonkeppen, kÿnek az arath zegÿneknek mind ez Ideigh sem attak megh: Melÿ dologh feleol mostannis keonieorgŭnk Vrasagtoknak, mÿnt Patronŭsinknak, Mÿert hogy ez dologh feleol wgian teorwentis lattattŭnk, ha azokra haramlik az kÿk el hordottak, wagÿ penigh az kÿ megh eotte, de az teorwen, Wngnodne Azzoniomra mutatta ennek megh fizeteset, Wrasagtok legÿen minden oltalommal es segetseggel ez dologban melletŭnk, mert mỷ nem tugÿuk honnet megh wennÿe, hanem az kÿ buzaia Wngodne, Azzoniomnak it mÿ keoztŭnk wolna, kÿert mostan erette Jeottenek hogy el witessek, Elegeÿtenek megh abol az Mezarosokoth, kÿth Wrasagtoknak eoreoke mind faluiŭl zolgalhassunk megh amÿ oltalomŭal, mellettŭnk tamad Wrasagtok.

Wrasagtoktul, erreol ez dologrul kegÿelmes walazt warunk, az ŭr istentul urasagtoknak kÿwanŭnk io Egésseget, es az ŭr isten eltesse wrasagtokoth sok io eztendeigh,

Datae ex heÿsze 20 Julÿ Vetus Calendarii Anno 1588

Gener': Egr': V: Dominationum

Seruitores humillimi

Judices et Jurati

Ciues oppidi heÿsze 


\section{II.15.}

Tokaj, 1588. IX. Tokaji jobbágyok levele.

Mj w Felseghenek Tokayban lakozo meǵ niomorodoth Jobbagj kiczintwl foguan nagigi Nagtoknak mint kegielmes Patronusinknak iaroluan alazatosan eleikben keonieorgeok az hatalmas Istenert Nagjsagtok keonieorgeseonkeot, meǵ halgatuan legien otalommal az Nemeth witezek ellen, kik mind nilŭan smind titkon szenuedhetetlen dusagot es koborlast czielekednek szeoleinkben ugy'anniera hogy' egy' giwmeolczeot egy' fw zendwlt szeoleot twleok meǵ nem tarthatonk, hanem hol haton hol heten, tizen tizenketten feleseghestwl szeleinket fegy'ueres kezzel ugy' iariak, koborolliak es horgiak. Panaszolkodonk az Varban ualo tiszt uiseleo fw Nemeteknek de semmy hasna Panaszolkodasonknak, el keseretteonk. nem tudonk hoŭa lennj ha Naǵtok modot nem talal, az mi ioszagonknak otalmazasaban. Tudgia Nagtok hogy' mi nekeonk sem szantho feoldeonk sem egieb kereskedeseonk hanem Jsten utan cziak az szeoleore kel szemeonket uetneonk es abbol magonkot czieledesteol taplalnonk, ha aztes twleonk aramith (?) el kesztek nagy' kemelletlen el fosztiak, nem tudonk egiebet mith rayta gondolnonk, hanem ha szeoleochkeinket parlaǵua hagjuan kj budosonk helionkbeoll. mert aminth hozza fogtak szuretig męg nem hogy' felet de cziak harmad reszetis szeoleo teremeseonknek, mely annelkwlis fel szerent uagion meǵ nem valyattiuk miattok, ki w felseghenekis felette igen nagy' karara, de mi nekeonk ugian szenuedhetetlen romlasonkra vagion. Nagtoknak annakokaert az hatalmas Istenert keonieorgeonk ne hadgion Nağtok hanem tamadgion melletteonk es uessen tilalmat nekiek, mert bizoniara mi semmikeppen meǵ nem fogiuk alhattnj aminth nekeonk czielekedenek. Irtonk supplicatiot ezen es felwl w Naganak Groff Vronknakis, Nagsagtok embereuel legien w Naga elwttis szegetseggell, parancziollion w Naga ne romczionak illien keppen benneonkeoth, mert az Jsten nekeonk bizonsagonk hogy' nem tudonk hoŭa lennj miattok, es az w felseghe hiusegeben es szolgalattiabanis meǵ kel fogiatkoznonk

Joh ualaszt uarunk Naḡtoktul es keuanonk az Vristentwll Naḡtoknak minden lelkj es testj io aldast

Ew felseghenek Tokayban lakozo meg Niomorodot Jobbaghj, feienkent kiczientwl fogua Nagiǵ. 


\section{II.16.}

[H.n.] 1588. X. Tábor János levele.

Eorokke ualo zolgaltomat Irom kogelmetoknek, mint tiztolendo nagsagos Vraimnak, Istentw̄ keuanom mind tosti és lolki aldasat Vrasagtoknak,

Ez felol kolletek kogelmotoket mog talalnom Hog ez el mŭlt napokban, JW̄ek fol az poganok kozzw̌l es Az harmincadra Onadban terek be, es annak modgia zorent mog kerdek ki neuen es honan es ualo uagiok, Es mog mondam hogi Rackeui uagiok De en soha tobbe oda nom megiok, Es fol irak az mi kicin marham vagion ŭgi mint Egi fertali masa bort, otuen niolc Jancsar kapcza, ket ueg zelenek zel, neg forint ara selom sinor, Es mondanak hogi tartua uagi attiamfia mind marhastul Kamora akarattiabol Mert minekw̆nk meg parancsoltak hogi rackeui embort, Kŏròsi Embort, Cogledi embört, Marosi Embort, tolnai embort, meg tarcsunk mind marhastul, Es miuel hogi ot ualonak irattad magadat feiemer sem mernem el halgatni, Hogi kamorànak tuttara nóm adnam Az ert im leuelet irok es uid fol az kamorara es igazicad dolgodat Ez leuelet fol hoztam mint hogi

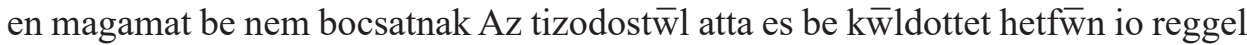
de en nom tudom kinek attak Azert ismeg az ennon kezemmel Irtam Vrasagtoknak mastan Hogi az istenre tekentue nagsagotok tegion kogelmes ualazt mort en oda soha nom megiok Ha nom kiralnak ŭ folsegenek zolgalni akarok holtomik, En nekom semmi oroksegom nincsen ot, som felesegom nom uolt megh, mort Giermoksegom uta mind mast zolgaltam csak im Eztendeienel keuese tob Hog $<$ im> az Kadassak hoz kezdóttem. Az Vristenert is kerom kogelmetoket hogi $<$ kogiel $>$ Nagsagotok $<$ at $>$ adgion kogelmes ualazt, mort igon J $\breve{w} \breve{w}$ euen uagiok ez foldre es istennel tob sonki ninc ertem auagi melettem torekodo, mort Bizoni sok ehseggel Zomiscaggal faratsaggal Giuitottem ez kicsin marhackat. Istennek aldasat kiuanok Nagsagtoknak

Kegelmetok mogh bocsason ha ez leuelben uetek uagion

Ee tabor Janos rac keui

nagsagotok zolgaia

Ennek utanna Gonci

Akarok lonni Isten

Segetsege bol

Ferdinandus diuina favente clementia Romanorum Imperator semper augustus Infans Hispanorum. ${ }^{1}$

${ }^{1}$ Más kéz írása. 


\section{II.17.}

Sajónémeti, 1589. XII. Récsei Demeter levele.

Eŏreŏkke valo zolgalathunkath Aÿanliuk vrasagtoknak, minth mÿ nekunk Isten vthan gond viseleoinknek es Patronusinknak

Istentul kiuanunk Vrasagtoknak ez wÿ eztendeoben minden Jokat es Bodogssagos Jletet meg Adathni

Vrasagtokath Jllien dologrulis kelletek meg thalalnunk hogÿ Ez elÿ multh Napokba egÿ Borbelÿ leginÿ melÿ darabonsagoth sem viselth henem cziak fizetet lennj volt, egÿ Chÿaszar Jobbagiat ezen $\ddot{w}$ felssige varossabanj puskaiaual meg leówe melÿ sebbenj vgianj megis hala az Cÿaszar Jobagia az Varba be esek, az Varbol Senk vrunktul nagÿ nehezen kÿ kireỏk azt az gilkost teoruinÿre az teöruinÿ halalra sentenciatha mint gilkost Erōssen tartatuk. kih volth az meg holth Embernek az felesige Rea allania ${ }^{1}$ heted magaual Jsmeth kalodankbol az Nemetek Reank Jeōwenek kÿ vönek Erōuel, Nem thwdunk mit tennj Jgÿ viszik kÿ az gonoz tiweŏ Embert $<$ kezwnkb $>$ kezunkbol, Annak felette Ez el mult napokban meg Jllien dolog teōrtinek Ezen Varosbanj hogÿ Egÿ leannak egÿ polgar hazanal germeke leot az germekit az leanj meg ölte es ladaibanj thalaltak megh az mÿ Varossunk teorūine szerint elis vermeltettwk az leant, miuel penig hogÿ polgar hazanak teôrtint, es gianakottunk hozzaia, hogy tutta volna, vagÿ ẅ maga, vagÿ hazza nepe, azt az polgart mÿ teöruiny (!) megh kezessitetettwk wgÿ Anira hogÿ tizen egÿ Ember kezes Jrette thanacÿ belÿ Emberek, Mostan Jmmar Vduarbiro vram teöruentul nem vart ha vagionj vitke Rea ha tutta volnaj auagy nem hanem altal vitette. $\ddot{\mathrm{w}}$ kegelme vÿonnan kezessitette Vrasagtok Emlekezhetik Reaia hogÿ az $\ddot{\mathrm{w}}$ felsige priuilegioma is zabatsagot adot Erre hogy az Varos biraia az gonos tiueoket meg buntethesse teöruiniel, Nem thugiŭk Mÿ az oka es honnet ligien ez ez hallatlan dologh varossunkon mert Jmmar anirra Jutottunk hogÿ az gonoz tiuoket is meg nem meriuk fognia Vrassagtokath az Jstenert kiriuk hogÿ ez fele hallatlan dolgot ne szenuegien Vrasagtok Rajthunk Chjelekedenie Nem tugiuk mire valo az zeginj biro Varossunkban toruinth titetnek velunk es Annak az kÿ zolgaltatassara nem hadnak eleget tennuk hanem kÿ viszik kezunkbolazirt vrassagtokatth kiriuk az Jstenert hog Vrassagtok hagia az zeginj varost Jo Renbenj, $<$ kit $>$ melliet Vrasagtoknak zolgalhassunk megh es meg az germekinkis Vrassagtok (!) vganj mondhassunk sok Jokath. Isten Jltesse Vrasagtokath nagÿ sok Eztendeigh

datum Nimethinj

Judex primarius Demetrius Rechej

Nemetthiensis Ceterique Juratj Ciues.

${ }^{1}$ Eckhardt Sándor a következő olvasatot is lehetségesnek tartja: allaina. 


\section{II.18.}

Tokaj, 1592. Kalmár Benedek levele.

Erthem Vram hogj keǵd azt kiuanja en twlem hogj Irua adgiam keǵd elejben, hog es minth esetth az dologh es haborusagh Imre Deak keözeötth es Bus Gaspar keözeötthj keǵd itthon nem leteben, En azt mondhatom Gaspar deak feleöl, hogj uala ennalam egj Meniechke, kj ennekem leanzo koraban szolgalom volth, es en hazasitotta $m$ elis tiztessegessen. Jöue hozzam mas Aszonj allath es monda hogj ne tarchiam azt az Aszonj allatoth hazamnal. En az Aszonj allatoth rea kérdém, mj okért ne tartanam hazamnal, Monda uiszontaksaggal, azerth hogj az katonakkal beszel az Vrais az Meniechkenek azon panaszolkodjk hogj eöteth nem szeretj, hanem az katonakoth. En az töruen szerinth megh lattattam ha ugj uagione auagy kẅleömben. Az töruen ugj talalta hogj az Meniechenek az Vra rea keresse törvennjel, es az töruen napigh megh tartassa. Ennekem annak utanna az erössegben kelletth tetetnem, az töruen napigh meghis tartattam, es az töruen elejben elö hoztam, noha szolghalom $\breve{w}$ de en semmjben oltalmaznj nem akartham, Jollehett az migh igassaga tartotta mellette voltam, megh gondoluan elöbbj szolgalattiath. Az Menjechkenek az Vra igaz annjth felelteteth hozza az menÿth szinte akarth, Gaspar deakkal, ugj minth procatoraual, annak utanna tanoiual beŭsseges sorokath hitt szerinth bizonitatot reáa. En azt mondom hogj mjuel az törven ugj talalta, es sententiazta az tanuk utan, az Menjechketh, hogj heted magaual menchie megh maghath, ha megh menthetj menth ember leszen, ahol penigh meg nem menthetj, tehat az ura heted magaual allion rea es vtesse el az fejeth. Azerth megis azt mondom Gaspar deak, chiak procator uolth ez dologban az leghen melleth. Es Gaspar deak ok nekwl panazolkodoth en ream predicator vramnak, kjerth az predicator engemeth az Anja szenth egj hazban ki predjcalloth, velem egjetemben annak felette ez itt walo tiztarto vrajmoth, illien keppen hogj mj tartiŭk az fele tiztatalan szemelnek partjath, kjualthkeppen (azt montha) te biro az njluan való paraznanak partjat fogod; mondta aztis az predicator vram, Hogj azt mongia az Iras hogÿ atkozoth az az kj az njluan valo paraznanak partiath tartja. kibeöl nekem azt mondom hogÿ egj tsepp vetkem sinchien. Gaspar Deaknak kelletth volna mondom azt, az szemelt eröltetnj az kjnek peritth fel vette, hogÿ el iarion az eö dolgaban, az mintt az teörven talalta. es nem engem kelletth volna az predicatornak, be vadolnj, sem aztöb tiztarto Vrajmoth, meth en az en tiztemben hiŭen el iartam. Azerth ugj mondom hogj Gaspar deak meltatlan vadolth es panazloth az Praedjcatornak, es predjcator Vramis ok nekẅl predjcalloth kj.

Vgsanackor Vasarnap mikor minketh kj predicallottak, mjkor keǵd itthon nem volth keǵd kepebe Imreh Deak volth, Engem mindgiarth fel hiŭatoth, Imre Deak vram az Vduarba; Monda Mi dologh legjen az biro Vram hogj kj predjcallottak nem esmere $m$ abbol semmj vettkwkketh sem en sem keǵd. En azt mondam arra, hogj mostan fel mentem vala enis az predjcatorhoz hogj mj okerth chielekette azt 
rajtŭnk megh tudnj. Eö arra azt monda hogj Gaspar deak iött vala predjcatio elött hozzam, es eö vadola keǵdeth hogj az tiztatalan bẅnös Aszonÿ Allath melle penzen kereseth volna kjk megh esküttenek es en azokon czielekedtem az praedjcator monda. En arra azzt mondam hogj en nem kerestem mentö szemelieketh. En azonkeppen Imre Vramnakis megh beszellette $m$ mith beszelgette $m$ praedjcator Vrammal, azonközben Gaspar deakịs közinkbe Jöue, monda Imre Vram te Gaspar deak bestie hires kurŭa fia mjerth predjcaltattal megh bennw"nketh. Ha en akarom ezenel nekj vonjatlak es addigh veretlik (!)az migh én akarom. Azert ezfele szitok sok volth Imre wramtol Gaspar deakon. Gaspar deak arra azt monta chiak ne sziggion keǵd Imre vram engem, mert en keǵdeth nem praedjcaltattam.

Judex Primarius Benedjctus Kalmar, oppidj Tokaj.

V. D. Subiectissimus. 


\section{II.19.}

Tokaj, 1592. VIII. Imre deák levele.

Keǵmed akaria tőllem meg tudnj mint haborottam ôzue Bus Casparral, Az oka ez uolt, hogj a biro Kalmar Benedek, fogot uolt meg egj Azzonj allatot ualamj paraznasagh uetkeiert hogi keḡ: ithon nem uolt, annak az Vraual uolt töruenie, az Törŭenj mentseget adot az Azzonnal az mint az birotol ertettem, hogi hetedmagaual meg menche magat tizen ŏtŏd napra, m’gh az Tizenŏtŏdnap elö Jöt addigh az Biroual Bus Caspar ózue habarodot, azt mondotta hogi, Te b’ro te magad penzen akarz hitlõ tarsokot az parazna melle keresnj, mert ket Azzonj Emberis mondotta hogi te kerestecz hitlõ tarsokot melleie. Erre En nem tudom az bÿro mÿt zollot nekj felöle, wk tuggiak, ez egj Vasarnap napon uolt, menenk az predicaciora, tehát Bus Caspar futot az predicatorhoz erőssen panazolkodot nekj, az Praedication, mingiarast Paraznanak Párt tartoÿnak praedicalla bennőnket az praedicator, Ebben ez dologban mint hogj sem en sem keǵmed nem tudtonk semmit En bizoni ighen zegiellettem hogj illien nagi gialazat eset meltatlan raitunk az egez varas előt, hizem nem olj czegeres latrok wagiunk mj, sem olj gonoz teŭő Emberek, hogj minket publicè mint ollian gonoz Életw" embereket az kereztienek kőzzẅl kj praedicallanak, ugian el holtam uala zegielletemben Annj sok Jambor előt, haza Jőuek mingiarast ide az $\ddot{\mathrm{w}}$ Felseghe hazahoz, hiuatam az birot hogj erchem meg mi dolog legien ez raitunk eset nagi gialazatnak az oka, az biro meg monta hogi Caspar deak uezet w" uelle őzue az Azzonj allat mÿat az ki w nalla fogua uagion, es $\ddot{\mathrm{w}}$ futot az praedicatorhoz, ualamint atta Elejben à dolgot de am halla keǵmed melj gialazatot praedicalla az praedicator. Erre en azt mondam az bÿronak, hizem En uolnek mostan Vduarbiro Vram kepebelj Ember, mint hogj Sÿlindj Ideiebenn is En uoltam, Ennekem kellet uolna Bus Casparnak panazolkodnj kegielmedre, En mind kettőtöket Elö hiuattam uolna, meg hattam uolna En keǵmednek hogj az Toruenj az mit hozot arra az Azzonjra, foliasabol keǵmed se uegie ki az tőrŭent, ha penig mas ualazzal kellett uolna benneteket boczatanom, massal boczattalak uolna, mÿ reank nem praedicaltatot uolna, mert a' kereztienek kőzzól, czegheres lator Eletw̌ Embert zoktak ki praedicallnj, de gondom lezen rea. Az utan Bus Caspart ŭgj hiuattam Elö w" nekÿs azt mondottam az mÿt az bironak, hogj mÿert czelokedet illien nagi gialazatot raitŭnk, arra azt monda, hogi nem $\ddot{w}$ cselekette, mondam hizem az biro w" maga monda, masod zauaban Esmeg azt monda hogi nem mj rank zolloth hanem az bÿrora felesegestól, mondam hogi tudod azt, mj semmj dolgotokat nem tuggiuk, illien nagj gialazatot nem Erdemlẅnk mert mj Jamborok uagiunk, ha te Emberseghes ember uolnal, nem kellet uolna Vduarbirodat hatra hadnod, hizem nem az praedicator uiselj ith az wै Felseghe Jozaghanak gongÿat, Erre nagj frissen kezde morganj, tehat meǵ Ẅ foghia fellieb az dolgot ezen ugian el busulek, hogj minket w praedicaltatot kj artatlanŭl, ha En az mj tiztessegw"nkert zollok megh w' haragzik, ugj ŭagion Aztis 
gondolom hogi Keg: ithon ninczen, mert az mi tiztessegw"nknek kissebbiteseiert, kiualkeppen hogi illien meltatlan zenjŭedgw"k, nem hogj meg nem zidogatnam, de hizem eletemetis el kellene ueztenem tiztessegönk mellet. En zittam, de az mint az Camoran panazolkodot hogj öllessel feniegettem, nem igazat mond benne, mert az Giőrj Ambrus Deakkal fenieget uala, hogi sohul meg nem maradhatok elötte ha wै raita ualamÿt czelekedem, Arra mondam, hogi ninczen semmi közóm az Attiad fiaual, zolgalok inkab nekj, hogi nem ueczek de mas uagj te nem Ambrŭs Deak. Ebben all az dologh, de nem hogj zidogatast Erdemlet uolna, de sőt hogi bw̋ntetesreis melto uolt uolna, hogj illien gialazatot kellet mÿatta zenjuednónk bw̋ntelen es meltatlan, sőt bator kőzonnie aztis ha czak Ebben mŭlik az dologh, talam rŏuid napra Enis fel megiek az Camarara ha Isten Egesseget ad, bizonj meg latom mÿt zol w keǵmek felöle, addigh nem zollok semmit, talam meg tanol, hogj ha czak egj giermeket hagj tiztartoia kepebennis, meg beczẅllỳ, meg tartoztattia az nielŭet, nem pizkal oknelk ${ }^{\mathrm{w}} \mathrm{l}$ senki tiztessegheben, Isten kegddel k. zolgal

Imre Deak. 
A II.1-19. levél első megjelenések helye

\begin{tabular}{|l|l|l|}
\hline A LEVÉL SZÁMA & A LEVÉL DÁTUMA & FORRÁS: Magyar Nyelv \\
\hline II.1. & 1574. III. 8, Nagyszőlö & $50: 204-205$ \\
\hline II.2. & 1577. Sajókeresztúr & $54: 370-371$ \\
\hline II.3. & 1577. XII. Gergelyi & $54: 556-557$ \\
\hline II.4. & 1577. Tiszaeszlár & $54: 559-560$ \\
\hline II.5. & 1580. X. 18. Tardoskedd & $45: 332-334$ \\
\hline II.6. & É. n. [1580] Kissár & $50: 486-490$ \\
\hline II.7. & 1581. I. Felsőbánya & $49: 211-212$ \\
\hline II.8. & 1581. IV. Felsőbánya & $49: 212$ \\
\hline II.9. & 1582. Dorog (Nánás, Varjas, Vid) & $56: 390$ \\
\hline II.10. & 1584. XII. 9. Vámospércs & $59: 481-482$ \\
\hline II.11. & 1588. I. [?] & $59: 486$ \\
\hline II.12. & 1588. II. 28. Miskolc & $49: 496$ \\
\hline II.13. & 1588. III. Tarcal & $49: 496-497$ \\
\hline II.14. & 1588. VII. 20. Hejce & $49: 495$ \\
\hline II.15. & 1588. IX. Tokaj & $49: 498-499$ \\
\hline II.16. & 1588. X. [?] & $49: 499-500$ \\
\hline II.17. & 1589. XII. Németi & $49: 501$ \\
\hline II.18. & 1592. Tokaj & $49: 213-214$ \\
\hline II.19. & 1592. VIII. Tokaj & $49: 214-215$ \\
\hline & &
\end{tabular}


Névmutatók 
A mutatók felépítése során is törekedtünk a minél érthetőbb szerkesztésre, így a betürendben álló tulajdonnevek első, félkövérrel szedett alakja a mai használatot mutatja, mellettük zárójelben a jobbágylevelekben megtalálható, más helyesírással, más hangjelöléssel és/vagy hangalakkal szereplő változatok állnak. Ezt követi a címszónak a levelekben megjelenő összes előfordulása.

A mai földrajzi nevek között a már nem használatos névformákat is címszóként vettük föl a félkövérrel szedett listába, $\mathrm{s}$ azokat ld. jelzéssel a ma érvényben lévő földrajzi nevekhez irányítottuk, az oldalszámokat a mai alaknál tüntettük föl (például Kremnecz ld. Körmöcbánya).

A [gr] jelzéssel álló tételek esetében a tulajdonnevek alanyesete az egyes szövegekben nem meghatározható, vagy visszakereshetetlen, pl. Eger (egren [gr], Egrÿ [gr], Egrj [gr]), illetve akkor is [gr]-val jelöltük az alakváltozatokat, ha azok latin szuffixummal ellátva latinosított névváltozatra utalnak, pl. Szokol (zokolienses [gr]).

Két esetben kérdőjelet tettünk a címszó elé, az itt föltüntetett nevek mai helyesírása és alapalakja bizonytalan.

A jel egyrészt a ma legalább kétféle névváltozattal élő családnevek között szerepel, másrészt $\sim$ került a hasonló írásmódú és többféleképpen olvasható családnevek címszavai közé is, amelyek esetében a szövegekből eldönthetetlen, mely családra vonatkoznak. 
A levelekben előforduló tulajdonnevek

Almássi György (almassi gwrko) 37 .

Andrássy Péter (Adraszÿ petter, Andraszÿ Peter, Andrassÿ Peter, Andrassÿ petter, Ādrassÿ Petter) 127, 131.

Bakó Tamás (Bako Thamas) 159. Balassi Bálint (Balassi Balint) 216. Balassi Miklós (balasi miklos, Nicolaum [gr] Balassa) 204.

Balassy János (Balassÿ Janos) 196, 197.

Bálint deák (Balint deak) 214.

Balog Imre (Balog Imreh) 121.

Balog Tamás (balog tamas) 37, 39.

Bánffy István (Banffÿ estwan) 29.

Báthori (bathori) 15, 21.

Bebek 107, 163., 177.

Bele János (Bele Janos) 214.

Benedek deák (Benedek Deak) 212.

Boldizsár deák (Boldisar deak) 199.

Bornemisza Imre (bornemiza Imre) 57.

Burja Péter (Burya peter) 157, 159.

Bús Gáspár (Bus Gaspar, Bus Caspar) 221, 223.

Csáky Dienes (Ciakÿ dyenes) 83.

Csát Máté (Chat Mathe, Matthej Chatt) $135,137$.

Csató Miklós (Czato miklos) 121.

Cseh Albert (cheh albert) 159.

Csetneki János (czetneki Jonos, czetneki Janos) 61.

Csetneki László (Czietnekj Lazlo) 57. Csók Márton (Chiok Marton) 159.

Csutor János (Czutor Jannos) 207.

Debreközi János (Johannis

Debrekezÿ, Joannes Debrekozi) 183, 187, 189.

Debrői Márton (Debrej Marton) 201.
Derse Ambrus (Derse Ambros) 73.

Detkovity Detkovics Miklós

(Detkoŭith Miklos) 87.

Dóczy András (Doczÿ Andras) 147.

Faragó Bálint (Farago balit) 73.

Farkasity Farkasits Gergely (farkasit gergol) 39.

Fátuly Kozma (Fatulÿ Kozma) 214.

Fekete Bence (fekete bence) 37.

Fekete György (fekette Geörgÿ) 69.

Forgács Imre (Forgacz Imre) 169, 171.

Forgács Simon (Simoni Forgach) 187.

Fúrottas Dömötör (fwrottas domotor) 37.

Gáspár deák (Gaspar deak) 221, 222.

Gatya Máté (Gatia Matae) 159.

Gellért Dienes (Gelerd gienes) 73.

Győri Ambrus (Giőrj Ambrus) 224.

Hazon aga (Hazon aga) 198.

Hév Pálné (Hew" Palne, Heww palne)

157, 216.

Herczeg Ernestus (Ernestŭs Herczegh) 171.

Homonnai György (Homonnaj

Giórgÿ) 117.

Horváth Márk (horuat marko) 41.

Horváth Mátyás (Horüath Matias)

213.

Hosszútóti János (Hozzwtotj Jannos) 47.

Ibrányi Ferenc (Ibranj Ferencz) 201.

Imre deák (Imre Deak) 221, 224.

Kalmár András (kalmar andras) 37.

Kalmár Benedek (Kalmar Benedek, Benedjctus Kalmar) 213, 222.

Károly László (Carolÿ Lazlo) 83.

Károli Mihály (karolÿ mihal) 77.

Kis Mátyás (kis mathias) 121. 
Kola Pál (Kola Pal) 159.

Kolbász János (Kolbaz Janos) 214.

Kolbász Lőrinc (Kolbaz leórincz)

214.

Kolonics Ádám (Adam Kolonicsz) 165.

Komár István (komar Istuan) 149.

Kovács János (Janos kouacs, Janos Kouachs) 157, 216.

Lázár Simon (Lazar Simon) 214.

Magócsy (Magochÿ) 117.

Makay János (makaÿ Jannos) 15.

Major Ambrus (maÿor amborus) 37.

Méhes István (mehes estuan) 121.

Miklóssy János (Miklossi Janos) 204.

Molnár János (Molnar Janos) 214.

Molnár Simon (Molnar Simon) 214.

Morzsoló Máté (Morsolo mate) 37.

Nádasdy (nadasdÿ) 21.

Nádasdy Ambrus (nadasdj amborus) 37.

Nádasdy Tamás (nadasdi tamas, nadasdj tamas) 39 .

Nagyvathy Ferenc (Fransisco [gr]

Nagjŭathj) 115.

Nagy Gáspár (nagh gaspar) 37.

Nagy István (Nagj Istuan) 214.

Nagy Pál (Nagj Pal) 214.

Nagy Sebestyén (nagh sebostÿen) 37.

Nyeste Márkus (Neste Markus) 214.

Orosz Vaszkó (Oroz Waszko) 214.

Panka Péter (Panka Peter, Petrŭm [gr] Panka) 109.

Paczoth János (paczot Janos) 109, 165.

Pálffy Tamás (palphi thamas) 91, 93.

Polyka Orbán (Polyka Vrban) 73.

Pribék Mihály (Pribek Mihalÿ) 213.

Putnoky Boldizsár (Putnokj Boldisar)

212.

Rakomazy János (Joannes Rakomazj, Joannis Rakomazÿ) 81, 83, 85.
Rácz Pál (Racz Pal) 169, 171.

Radics Benedek (Radicz Benedek) 213.

Ráduly Demjén (Radoly Demjen) 214.

Ráduly János (Radoly Janos) 214.

Ráduly Péter (Radoly Peter) 214.

Rajki Gábriel (Raykj Gabryel) 31, 33.

Rajki János (Raykj Jannos, Raÿky Jannos) 31, 33.

Ravai Ferenc (Francisco [gr] de raua) 59.

Récsei Demeter (Demetrius Rechej) 220.

Rudolf fejedelem (Rodolfus [gr]) 169.

Ruber Rüber (Ruber, Rüber) 61, 79.

Russel (Russel) 183, 185.

Sáfári (Safari) 107.

Sárközi Boldizsár (Sarkozi boltissar) 37.

?Schenk (Senk) 220.

Serényi (serenj, Zerenj) 29, 43.

Sólyom Miklós (Solyom Myklos) 73.

Somody Zsigmond (Sigismúndus

Somodÿ) 151, 153.

Soós András (Soos andras) 185.

Sótai (sotai) 107.

Süveg Ferenc (Sw"ueg ferencz) 159.

Szabó Balázs (szabo ballasz, szabo balas) 214 .

Sajgay Bálint (saẏgaẏ Ballint) 214.

Surány Gábor (Surany் Gabor, Suranÿ Gabriel) 214.

Szabó Pál (Zabo Pal) 73.

Szabó Gergely (Zabo Gergely) 73.

Szabó Mihály (Michaele zabo) 159.

Szakály (zakoli) 183.

Szavór Friedrich (szauor Fridrich) 165.

Szőlőssy János (Zewlessÿ Janos, Zewlessÿ Jannos) 19, 25.

Tábor János (Tabor Janos) 219. 
Telegdi 183.

Törtöli Balázs (Tórtólj balas, Terteli

balas, Tórtólÿ Balas, Tórtólÿ balas)

119.

Tőke Tamás (Thőke Thamas) 159.

Tompa Ferenc (Tompa ferench) 196.

Turi Benedek (twri Bennedek, twri

Benedek) 91, 93.

Ungnád (Wngnad) 217.

Ungnádné (Wngnodne) 217.

Ursinus Ferenc (Vrsinus ferencz) 177.

Uzsalj Péter (Vssalÿ Peter) 206, 207.

Varczot Miklós (varczot miklos) 79.

Varga Bálint (varga balint) 159.

Verner (vernnerius [gr], vernerius

[gr], wernerius [gr]) 15, 25.

Zoltai István (Zoltaj Istwan) 99.

Zsóry Pál (Sorj pal) 99. 
Almás ld. Szádalmás

Alsószerdahely/Felsőszerdahely

(vaga szerdahelÿ, Szerdahelÿ,

Zerdehel) 141, 205.

Bécs (Becz) 107.

Böszörmény (Beszermenÿ) 149.

Bussa 197.

Cegléd (Cogled) 219.

Csetnek (cetnek) 57.

Debrecen (debreczem, Debreczen) 65, 149.

Dédestapolcsány (Dedes) 198.

Dévény (Dÿwin) 197.

Dorog (Dorog, Dorogiensium [gr]) 65, 67, 117, 121, 212.

Dráva (drawa Mura kozÿ) 43.

Ecsed (Eczed) 213.

Edelény (Edelen, Edeleniensium [gr]) 179, 181.

Eger (egren [gr], Egrÿ [gr], Egrj [gr]) 21, 69, 121, 213.

Eperjes (Eperies) 185.

Eszlár ld. Tiszaeszlár

Esztergom (eztergam) 51.

Esztergom vármegye (eztergam war megye) 55 .

Ete (Ethe) 37.

Etyek (Egiek) 73, 75.

Felsőbánya (Felseo Banianien[sium] [gr]) 210.

Füzesgyarmat (Fẅzes Gỷarmat) 208.

Gencs (Gench) 83.

Gönc (Gonc) 219.

Gergelyi (Gergeÿ, Gergelÿensium [gr]) 200.

Gyimes (Gÿmes) 187.

Gömör ld. Sajógömör

Görömböly (Göreömböl) 69.

Görgö (Görgö) 99.
Halmaj (Halmay) 198.

Hejce (heÿsze, Hecze) 217.

Helméc (Helmecz) 201.

Helta[...] ld. Nagydisznód

Hévíz (Heǔwÿz) 206.

Inota (Innotha, Inothae [gr]) 95, 97.

Jablonca (Jablonczia) 129.

Jászó (Jazo, Jaszai [gr]) 19, 25, 165.

Kálló (Kalla) 65, 119, 213.

Kapornak (kaparnak) 31.

Kapnikbánya (Kapnÿk) 209, 211.

Károly ld. Nagykároly

Kassa (Cassa, Cassouie [gr]) 105, 109,

121, 145, 149, 183, 185, 191, 215.

Keresztúr ld. Sajókeresztúr

Kékkő (keko, kekö) 196.

Királyi (Kiralÿ) 87.

Kisbánya (Kÿz Bania) 211.

Kissár (kys Sar, kÿs Sar) 205, 208.

Körmöcbánya 209.

Kőrös (Kŏròs) 219.

Körtvélyes (kortŭollössÿ [gr]) 129.

Krasznahorka (Krasna hŭrka) 133.

Kremnecz ld. Körmöcbánya

Lápos (Lapos) 209.

Letenye (lethene) 47.

Léva (Leŭa) 171.

Lice (Liche, Licce, Lićze) 143.

Liszka ld. Olaszliszka

Lóhát (lohattÿ [gr]) 206.

Mándok (Mandok) 185.

Maros (Marusini, Marus, Marosienses [gr]) 175.

Mezőölved ld. Nagyölved

Mezőzombor (Zombor) 216.

Miskolc (Miskolcz) 215.

Mocsonok (Moczionok) 87.

Muhi (Mohÿ) 73.

Mura (drawa Mura kozÿ) 43. 
Nagybánya (Nagy Bania, Rivůlienses [gr], Riŭŭliensium [gr], Riŭŭlis) 113, 115, 210.

Nagydisznód (Helta[...]) 119.

Nagykároly (Caroll, Carol, karolj, karol, karolili) 79, 83.

Nagyölved (nagÿ eẅlwed, Eolwed, mezö Eẅlwed) 49, 55.

Nagysár (Nagj Sar) 207.

Nagyszombat (Nagi zombath, Nagj Zombat) 171, 205.

Nagyszőlő (Nagÿ Zeoleö, Nagÿ Zeoleÿ [gr]) 197.

Nagyveszele (Nagj Vezele) 206.

Nánás (Nanas) 117, 212.

Németi ld. Sajónémeti

Németország (Nemet orszag) 165.

Nógrád (Neugradiensi [gr]) 197.

Óhát (Ohat, o hat) 73, 75.

Olaszliszka (lizka) 123.

Ónod (Onod, Onad) 73, 187, 219.

Oroszfalu (Oroz falu) 183.

Pálca ld. Tornyospálca

Pelsőc (pelsöcz, pelsẅc, pelsoczē) 57, 61.

Pest 198.

Petri (petrÿ) 77.

Piskolt 77, 79, 83.

Práznóc (praznocz) 205.

Püspöki (Pÿspeki, Pyspekiensis [gr]) 135, 137.

Pozsony (Posom) 19, 175.

Ráckeve (Rackeui [gr], rac keui [gr]) 219.

Rákos (Rakos) 143.

Reszege (rezege) 77.

Rivulis ld. Nagybánya

Rugás (Rugas) 109.

Ruszkai-hegy (Ruskai heg) 105.

Sajógömör (Sayogemer, Saÿo gemer, Gomor, Shajogemeriensis [gr]) 99, 103, 105, 109.
Sajókeresztúr (kereztur, kereztúr, Saio kereztur, Saio kereztŭr) 147, 149, 198, 199.

Sajónémeti (Nimethinj, Nemetthiensis [gr]) 220.

Sajótúr (Sajotur) 215.

Selmecbánya 209.

Selmecz ld. Selmecbánya

?Sloÿor 211.

Szádalmás (almassÿ [gr], almassi [gr]) 129.

Szádvár (szardvar, Szard var, Zadwar) 167.

Szalacs (Zoloc) 57.

Szárnya (Szarna) 99.

Szatmár (Zakmar, Zathmar) 209, 213.

Szatmárnémeti (zakmar nemetÿ) 21, 25,79 .

Szepes (Scepus, Sepusiensem [gr], Scepŭsiensis [gr], Scepusiensis [gr]) 67, 81, 85, 115, 153, 181, 191.

Székelyhíd (Zekelhid) 79.

Szendrő (Szendreÿ [gr], Szendörö, Zendrö) 71, 99, 107.

Szentgyörgy (Zent Geörg, Zentt Geörgj, zent Georgj) 207, 208.

Szentmárton (zent Marton) 185.

Szerdahely ld. Alsószerdahely/ Felsőszerdahely

Sziget ld. Szigetvár

Szigetvár (zÿget) 36, 41.

Szokol (zokolienses [gr]) 185.

Tarcal (Tarczal, Tarcaliensium [gr], Tharczaliensium [gr], tharczal) 147 , 157, 159, 161, 201, 216.

Tardoskedd (tardos ked) 53, 204.

Tarsolc (Tharsolcz) 214

Tárkány (Tarkan) 187.

Tisza (tÿza, Tyza) 15, 73, 147, 155, 212.

Tiszaeszlár (Ezlar) 201. 
Tokaj (Thokay, Thokaÿensis [gr],

Tokaÿ, Tokay, Thokaj) 73, 147, 151, 159, 212, 213, 218, 221, 222, 223.

Tolna 219.

Tornyospálca (Palcha) 185.

Turc (Thurcz) 214.

Vágszerdahely ld. Alsószerdahely/

Felsőszerdahely

Újvár (wÿwar, Vÿwar) 196, 203, 205.

Vámospércs (Vamos Peczienses [gr])

213.

Várda (Varda) 183, 185, 213.

Varjas (Varÿas, Varias) 117, 212.

Vid (Wid) 212.

Zala 29.

Zombor ld. Mezőzombor 
A kiadásért az együttműködő intézmények vezetői felelnek Kiadta a Magyar Nyelvtudományi Társaság és a Magyar Nemzeti Levéltár

\section{Borítóterv: Molnár Anna Aliz}

Nyomdai munkák: Komáromi Nyomda és Kiadó Kft.

Felelős vezető: Kovács János ügyvezető igazgató. 
A Magyar Nyeluben a múlt század közepén Eckhardt Sándor közlésében ötven irat, illetve iratrészlet jelent meg folytatásokban a XVI. századi jobbágylevelezésböl. A misszilisek különösen fontos forrást kinálnak a nyelutörténeti kutatásokhoz, mivel az élönyelvhez közeli regiszterbe engednek betekintést a változások pedig jellemzően a beszélt nyelvben kezdödnek. Ezért összegyüjtöttük az anyagot, és megkiséreltük a levelek eredetijét is felkutatni, majd ezek ismeretében új átiratokat késziteni. (Nem minden levélnek került azonban elö az eredetije, ilyen esetekben puszta utánközlésre kellett hagyatkoznunk.) A kötet az anyagot és az átírási módszereket bemutató fejezetekkel kezdödik, és nérmutatókkal zárul. 